\title{
OF GENERIC NAMES
}

\section{OF THE SCALE INSECTS}

\section{(Homoptera: Coccoidea)}

Miscellaneous Publication No. 1015

Agricultural Research Service UNITED STATES DEPARTMENT OF AGRICULTURE 



\section{Historic, archived document}

Do not assume content reflects current scientific knowledge, policies, or practices. 



\title{
AN ANNOTATED LIST \\ OF GENERIC NAMES \\ OF THE SCALE INSECTS \\ (Homoptera: Coccoidea)
}

\author{
COMPILED BY \\ Harold Morrison \\ and \\ Emily R. MORrison
}

Miscellaneous Publication No. 1015

Agricultural Research Service

UNITED STATES DEPARTMENT OF AGRICULTURE

Washington, D.C.

Issued October 1966

For sale by the Superintendent of Documents, U.S. Government Printing Office Washington, D.C. 20402 - Price 55 cents 


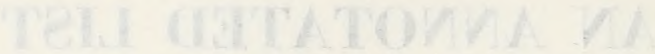

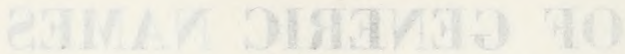

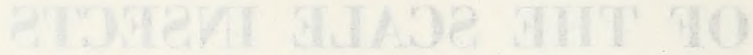

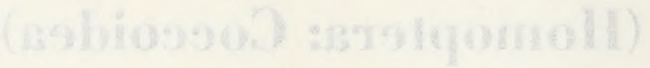

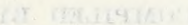

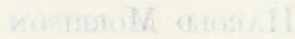

5.8.78

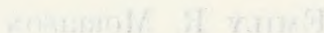

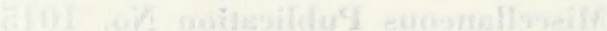

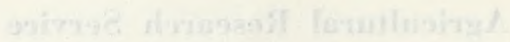

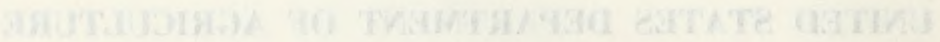




\section{An Annotated List of Generic Names of the Scale Insects (Homoptera: Coccoidea)}

Compiled by Harold Morrison, collaborator, ${ }^{1}$ and Emily R. MorRison, biologist, ${ }^{2}$ Entomology Research Division, Agricultural Research Service

\section{INTRODUCTION}

This list of generic names of the Coccoidea, or scale insects, is an outgrowth of a card catalog that has been maintained for many years in the identification unit of the organization currently known as the Entomology Research Division of the U.S. Department of Agriculture. A catalog of names, with associated data, is a prerequisite for taxonomic and other investigations of coccids carried on in the Department of Agriculture, and is equally valuable to other persons undertaking similar studies on this group of insects.

The compilation of a list of generic names of coccids seems to us to be especially difficult because of the early widespread use of certain coccids in the evolving economic life of man. Inevitably there was a comparable widespread, but inconsistent, reference to these insects and to coccids as a group in early post-Linnaean, scientific literature. Indeed, a review of authors and titles in the Horn and Schenkling Index Litteraturae Entomologicae, 1928-29, suggests that there may be several hundred early papers, beyond those already found, in coccid literature that could be examined for discussions that might affect coccid nomenclature. The probings of $\mathrm{L}$. Lindinger bear out this assumption. But such probings seem to us to have produced a very poor return and to have dealt serious blows to name stability, which is a very necessary constituent of current biological science. References to coccids appear in publications of several biological disciplines including taxonomy, economic entomology, insect anatomy and physiology, transmission of diseases, and minutely detailed problems of genetics. Under such circumstances it is imperative that fixity of coccid scientific names be sought, so that reference to any genus has the same significance in any publication, from general zoological or entomological text or reference book to the most re-

${ }^{1}$ Deceased.

${ }^{2}$ Retired. 
stricted paper on classification or genetics. Our concern for fixity carries especially to those few names which are historically significant, and our discussion of each of these, as they occur in the list, attempts to justify their retention and continued usage as valid and significant names.

We have attempted to fit each generic name into the pattern of availability outlined in the 1961 International Code of Zoological Nomenclature. In regard to spelling, we have, as a basic procedure, accepted the original published spelling of each name as the proper one for continued usage if the genus appears to be valid. If subsequent emendations have been suggested, they too have been listed, as well as obvious misspellings that usually can be attributed to manuscript or printer's errors. However, positive differentiation between incidentally proposed emendations and simple misspellings has not always been possible. Respecting already proposed or possible emendations, we decline to take responsibility for changes that would bring the generic names into strict accord with the provisions of Articles $26-33$ of the 1961 Code, for three reasons : First, it is our conviction that acceptance of original spelling is a simple, consistent, and satisfactory basis for establishment of a generic name; second, according to observations over the years, emendations either are largely ignored by other workers or their proposal stimulates long, drawn-out, often inconclusive, public debate over the legitimacy or the exact form of the change; third, as is pointed out in the late R. W. Brown's Composition of Scientific Words, 1956, the precise and correct formation of any zoological name may be an extremely complex task, demanding background training far beyond the experience of many, if not most, of today's students of insect taxonomy. For the future, we believe that a solution for this problem lies either in the acceptance of a generic name as it first appears in print or in the establishment of a competent, prepublication clearinghouse for such names by the International Commission on Zoological Nomenclature, or by some other agency located at a large center of work on zoological taxonomy.

Except through incidental reference under individual genera, no attempts are made to treat the classification of the coccids above the genus level. Although this group of insects was long accepted as representing a family in the general scheme of homopterous classification, the usual approach in recent years has been to accept the group as of superfamily standing, and Handlirsch (in Schröder, Handbuch der Entomologie $3: 1134,1925)$ even presented the group as subordinal in status, although he included only the one family, Coccidae. Various proposals for suprageneric groupings of the numerous coccid genera have been made since the publication of the Fernald Catalogue, 1903, but they have not been wholly consistent, and do not permit the assign- 
ment of all genera that belong with the coccid complex. Publications by Balachowsky, Borchsenius, Ferris, and Morrison (see Bibliographies) should be examined for studies in this area. It is our opinion that no classification system has evolved to a point permitting its rigid acceptance as a framework on which to hang all of the currently known coccid genera.

All names in the list have been cross-checked in Neave, Nomenclator Zoologicus, I-V, 1939-50, and various earlier compilations of scientific names and bibliographies have been freely consulted.

In presenting these coccid generic names, the original place of publication for each is given as a convenience. Further citations, in the discussion which may occur under a name, are presented in the abbreviated form of author name, year of publication, and page citation, and each may be expanded to a full literature citation by reference to the Selected Bibliographies (U.S. Dept. Agr. Misc. Pubs. 734, 1957, and $987,1965)$ which have been issued as a prelude to this work. The closing date of the list is December 31, 1963.

Painful amounts of time and effort have gone into the compilation of this list, and it is our hope that sufficient evidence is offered to satisfy other coccid workers that the information presented can be accepted as a foundation on which to build an evolving and continually improving system of classification for the Coccoidea.

Although the actual compilation of this generic list of Coccoidea has taken place recently, much of the initial information contained in it accumulated over a period of many years and was gathered by many persons. C. L. Marlatt started the catalog in the early 20th century as a continuation of the Fernald Catalogue. J.G. Sanders and E.R. Sasscer worked on it in its early years, and published several lists of generic and specific coccid names. Ida Weckerly was engaged in the endeavor for nearly 20 years.

The development of the catalog was under the direction of Harold Morrison for approximately 40 years. Dr. and Mrs. Morrison devoted their efforts for some months to listing, checking, and annotating: generic names, and to recording pertinent information. The manuscript was in rough draft at the time of Dr. Morrison's death on March 11, 1963. Mrs. Morrison continued the work, and added names that appeared later in the year. Louise M. Russell reviewed the manuscript, and actively participated in the preparation of the final draft.

We wish to acknowledge the assistance of several persons and organizations in the preparation of this list. Formal note should be made of the helpfulness of A Catalogue of the Coccidae of the World, by Mrs. Maria E. Fernald, published in 1903. The large amount of information brought together in that volume was the starting point for much of our review work on the older coccoid genera, even though our 
final opinions sometimes diverge strongly from the conclusions indicated in the Fernald Catalogue. The present staff of the National Agricultural Library of the U.S. Department of Agriculture and the personnel of the former Library of the Bureau of Entomology and Plant Quarantine assisted materially by locating and supplying copies of much of the early, frequently obscure literature that has been examined in the preparation of the list. The late Ruth O. Ericson, translator for the insect identification unit of the Department of Agriculture, translated various foreign language papers. Finally, we extend our sincere appreciation to our colleagues in the Entomology Research Division, and to all who have assisted in any way. 


\title{
ANNOTATED LIST OF GENERIC NAMES OF THE COCCOIDEA
}

\author{
Abgrallaspis Balachowsky, 1948, Actualités Sci. et Indus., Ent. Appl. \\ $1054: 306$. \\ TYPE-SPECIES : Aspidiotus cyanophylli Signoret, 1869, by original designation. \\ This genus was established for six species and was assigned by the author to \\ his Aspidiotina.
}

Acanthaspidiotus Borchsenius and Williams, 1963, Brit. Mus. (Nat. Hist.) Ent. Bul. $13: 381$.

TYPE-SPECIES : Aspidiotus pustulans Green, 1905, by original designation and monotypy,

The authors presented this genus in the Aspidiotini, close to Aspidiotus Bouché and Metaspidiotus Takagi.

Acanthococcus Signoret, 1875, Soc. Ent. de France Ann. [Bul. Ent.] (1874) (ser. 5) 4: ccxx; 1875, Soc. Ent. de France Ann. (ser. 5) 5 : 16,34 .

TYPE-SPECIES : Acanthococcus aceris Signoret, 1875, by monotypy.

This name has been widely accepted as a synonym of Eriococcus TargioniTozzetti, 1868. It was so considered by Ferris, 1957c : 85, and by Hoy, 1963, New Zeal. Dept. Sci. and Indus. Res. Bul. 150: 62. Lindinger, 1933a: 78, 107, considered it identical with Eriococcus, but placed both names under Nidularia Targioni-Tozzetti, 1868. Borchsenius, 1948: 501, 503, considered the genus to be valid, and transferred to it most species formerly assigned to Eriococcus.

Acanthococcus Kiritchenko, 1936, Rev. d'Ent. de l'URSS (1935) 26 : 155.

TYPE-SPECIES : Acanthococcus marrubii Kiritchenko, 1936, by monotypy.

This name was preoccupied by Acanthococcus Signoret, 1875, and was replaced by Spinococcus Borchsenius, 1948a: 953. This genus was assigned to the Pseudococcidae.

Acantholecanium Borchsenius, 1949, Ent. Obozr. 30:339-340.

TYPE-SPECIES : Ctenochiton haloxyloni Hall, 1926, by original designation and monotypy.

Borchsenius, 1957: 291, 308, discussed this genus, and assigned it to the Coccinae, Coccini. 
Acanthomytilus Borchsenius, 1947, Akad. Nauk SSSR Dok. (n.s.) $58: 344$.

TYPE-SPECIES : Lepidosaphes intermittens Hall, 1924, by original designation and monotypy.

The author associated this genus with Lepidosaphes Shimer.

Acanthopulvinaria Borchsenius, 1952, Akad. Nauk SSSR Zool. Inst. Trudy 12: 297, 301.

TTPE-SPECIES : Pulvinaria orientalis Nassanor, 1908, by original designation.

Borchsenius, 1957: 203, 285, discussed this genus, and assigned it to the Coccinae, Coccini.

Acantococcus Mitiaev, 1958, Akad. Nauk Kazakh. SSR Inst. Zool. Trudy Ent. 8: 79, 94.

A lapsus for Acanthococcus Signoret of Borchsenius.

Achorophora Brimblecombe, 1957, Queensland Jour. Agr. Sci. 14: 273.

TYPE-SPECIES : Achorophora ob7iqua Brimblecombe, 1957, by original designation.

The author placed this genus in the Aspidiotini, and suggested its resemblance to Pseudaonidia Cockerell.

Acledra Signoret, 1864, Soc. Ent. de France Ann. (1863) (ser. 4) 3 : 547 , of Kloet and Hincks, 1945, A Check List of British Insects, p. 76.

Kloet and Hincks presented Acledra Signoret, 1864, a ralid generic name in the Heteroptera, as an alternate to Aclerda Signoret, 1874, in the Coccoidea. In our opinion this is unjustifiable.

Aclerda Signoret, 1874, Soc. Ent. de France Ann. (ser. 5) 4:96; 1875, Soc. Ent. de France Ann. [Bul. Ent.] (1874) (ser. 5) 4: vii.

TYPE-SPECIES : Aclerda subterranea Signoret, 1874, by monotypy.

This name has been used consistently since its original publication to designate a group of coccid species, with rather specialized morphological characteristic's, which has been accepted as a distinct family since the establishment of the Coccoidea as a superfamily. The classification of the Aclerdidae was critically reviewed by McConnell, 1954.

Acontonidia Brimblecombe, 1957, Queensland Jour. Agr. Sci. 14: 285.

TYPE-SPECIES : Acontonidia triangularia Brimblecombe, 1957 , by original designation and monotypy.

This genus was placed by the author in the Aspidiotini, somewhat related to Pscudaonidia Cockerell. 
Acreagris Koch and Berendt, 1845, Neues Jahrebuch für Mineralogia : 873, nomen nudum; 1854, in Berendt, Die im Bernstein befindlichen Organ. Reste der Vorwelt 1 (2) : pl. 17, f. 157.

TYPE-SPECIES : Acreagris crenata Koch and Berendt, 1854, by monotypy.

This genus was based on a margarodid female from Baltic amber, originally described as an Aptera. Ferris, 1941: 6-10, gave a detailed discussion of this genus, its type-species, and probable fossil relatives. He accepted it as quite similar to existing Matsucoccus Cockerell.

Actenaspis Leonardi, 1906, Portici R. Scuola Super. di Agr. Ann. (ser. 2) $6: 4,25$.

TYPE-SPECIES : Leucaspis pusilla Löw, 1883, by monotypy.

This name has been placed by subsequent workers as a synonym of Leucaspis Löw.

Aculeococcus Lepage, 1941, Inst. Biol. [Sao Paulo] Arch. 12: 141.

TYPE-SPECIES : Aculeocoocus morrisoni Lepage, 1941, by original designation and monotypy.

This genus is currently assigned to the Eriococcidae.

Acutaspis Ferris, 1941, Atlas of the Scale Insects of North America (ser. 3) [v. 3] : SIII-328.

TYPE-SPECIES: Aspidiotus perseae Comstock, 1881, by original designation.

This genus was established for seven aspidiotine species, and its assignment to the Aspidiotini is generally accepted.

Acystomargarodes Bodenheimer, 1953, Istanbul Univ. Facult. des Sci. Rev. (ser. B) 18: 152 .

TYPE-SPECIES : Margarodes tritici Bodenheimer, 1941, by present designation.

This post-1930 generic name was proposed, in tentative fashion only, for two named species presumably having similar characteristics in the adult stage, but no type-species was selected at the time of publication. Regardless of any zoological validity, the name appears to be deprived of status by the restrictions of Article 13 of the 1961 Zoological Code.

Adelosoma Borchsenius, 1948, Akad. Nauk SSSR Dok. (n.s.) 63: 583.

TYPE-SPECIES : Adelosoma phragmitidis Borchsenius, 1948, by original designation and monotypy.

This genus was placed by its author as related to Pseudantonina Green in the Pseudococcinae.

Adiscodiaspis Marchal, 1909, Acad. des Sci. [Paris] Compt. Rend. 148: 871 .

TYPE-SPECIES : Diaspis (Adiscodiaspis) ericicola Marchal, 1909, by monotypy.

Balachowsky, 1949 : 109, and 1953g: 760, placed this name as a synonym of $R u$ gaspidiotus MacGillivray, 1921. The Marchal name has clear priority if the genera are accepted as identical. 
Adiscofionina Balachowsky, 1953, Actualités Sci. et Indus., Ent. Appl. $1202: 727$.

A lapsus for Adiscofiorinia Leonardi.

Adiscofiorinia Leonardi, 1906, Redia (1905) 3: 17, 52.

TYPE-SPECIES : Fiorinia secreta Green, 1896, designated by MacGillivray, 1921 : 372.

The author placed this genus as related to Fiorinia Targioni-Tozzetti.

Adisodiaspis Bodenheimer, 1937, l'Inst. d'Egypte Mém. 33: 218.

A lapsus for Adiscodiaspis Marchal.

Aegyptococcus Ezzat, 1963, 16th Internatl. Congr. Zool. Proc. 1: 192.

TYPE-SPECIES : Phenacoccus inermis Hall, 1925, by original designation and monotypy.

The author established this genus in the Pseudococcidae for the type-species of Mirococcus Borchsenius, 1947, and gave as his reason the absence from the original characterization of Mirococcus and the redescription of inermis Hall by Williams, 1958, of certain definite characters present in authentic material of inermis Hall. Since such an action is not in accord with provisions of the International Code of Zoological Nomenclature, Aegyptococcus Ezzat stands as a synonym of Mirococcus Borchsenius because of community of type-species.

Affirmaspis MacGillivray, 1921, The Coceidae, pp. 393, 448. ${ }^{3}$

TYPE-SPECIES : Aspidiotus socotranus Lindinger, 1913, by original designation.

Recent workers have placed this name as a synonym of Quadraspidiotus MacGillivray.

Africaspis MacGillivray, 1921, The Coccidae, p. 307.

TYPE-SPECIES : Diaspis chionaspiformis Newstead, 1910, by original designation.

Recent workers have accepted this genus as valid. Balachowsky, 1954e: 171, assigned it to his Diaspidina, chionaspiform group.

Africonidia McKenzie, 1947, Calif. Dept. Agr. Bul. 36 : 110-111.

TYPE-SPECIES : Africonidia halli McKenzie, 1947, b5 original designation and monotypy.

The most recent discussion of this genus, Balachowsky, 1958b: 149-150, 226, placed the type-species as a synonym of Gymnaspis africana Newstead, 1913. The original indications of relationship were with Aonidiella Berlese and Leonardi and Diaspidiotus Berlese and Leonardi.

\footnotetext{
${ }^{3}$ Neave, Nomenclator Zoologicus, I-V, 1939-1950, apparently consistently, supplies two page citations for MacGillirray's new genera; the need for this is not apparent to us and the second page citation is hereafter omitterl, except in the few instances where changes of spelling are presented.
} 
Afrotachardina Chamberlin, 1923, Bul. Ent. Res. 14: 201.

TYPE-SPECIES : Tachardia longisetosa Newstead, 1911, by original designation.

This genus was accepted in the latest catalog of lac insects, Kapur, 1958. Balachowsky, $1950: 9$, assigned it to Tachardinina.

Agrophaspis Borchsenius and Williams, 1963, Brit. Mus. (Nat. Hist.) Ent. Bul. $13: 375$.

TYPE-SPECIES: Aonidia buxtoni Laing, 1933, by original designation and monotypy.

The authors presented this genus in the Parlatoriini, close to Greeniella Cockerell in characters of the adult female.

Akermes Cockerell, 1902, Canad. Ent. 34: 89-90.

TYPE-SPECIES: Akermes bruneri Cockerell, 1902, by original designation and monotypy.

This genus is one of a group of several New World genera of which Toumeyella Cockerell apparently was first described. They belong in the Coccidae (str.) but have not been critically studied in recent years.

Albastaspis MacGillivray, 1921, The Coccidae, p. 295 (Albataspis, pp. $290,475)$.

TYPE-SPECIES: Mytilaspis nivea Maskell, 1895, by original designation and monotypy.

The describer indicated that the relationships of the genus are with Fusilaspis MacGillivray and Pinnaspis Cockerell. MacGillivray presented this name in two spellings. We are inclined to the opinion that his original intent was to present the alternate spelling as his established genus name, but Ferris, 1941a: 11, discussed this confusion, and arbitrarily chose Albastaspis, which must stand according to Article 24 of the 1961 Code.

Albataspis MacGillivray, 1921, The Coccidae, pp. 290, 475.

TYPE-SPECIES: Mytilaspis nivea Maskell, 1895, by original designation and monotypy.

See discussion under Albastaspis MacGillivray.

Alecaniochiton Lindinger, 1937, Ent. Jahrb. 46: 178.

An emendation of Alecanochiton Hempel.

Alecaniopsis Lindinger, 1932, Konowia 11: 178; 1937, Ent. Jahrb. 46 : 178.

An emendation of Alecanopsis Cockerell.

Alecanium Morrison, 1921, Philippine Jour. Sci. 18 : 648.

TYPE-SPECIES : Alecanium hirsutum Morrison, 1921, by original designation and monotypy.

Originally assigned to the Coccidae (str.), this genus has not been restudied for more precise assignment within the family. 
Alecanochiton Hempel, 1921, Arch. da Esc. Super. Agr. e Med. Tet. [Nictheroy, Rio de Janeiro] $5: 144$.

TYPE-SPECIES : Alecanochiton marquesi Hempel, 1921, by original designation and monotypy.

This genus was assigned by the author to the Coccidae (str.) without association with ans subgroup.

Alecanopsis Cockerell, 1901, in Cockerell and Parrott, 1901, Canad. Ent. $33: 58$.

TYPE-SPECIES : Lecanopsis filicum Maskell, 1894, by original desiguation and monotspy.

This genus was originally placed in the Coccidae (str.). Green, 1924b: 41-45, added three new species, but without suggestions as to the possible relationships of the genus to other members of the family.

Alichtensia Cockerell, 1902, Inn. and Miag. Nat. Hist. (ser. T) $9: \pm 51$.

TYPE-SPECIES: Lichtensia (?) attenuata Hempel, 1900, by original designation and monotypy.

This genus is known to include at least three species which probably are more or less related to Ceroplastodes Cockerell. It was discussed by Lizer, 1942a : 322-324.

Alioides Brimblecombe, 1958, Queensland Jour. Agr. Sci. 15 : 91.

TYPE-SPECIES : Aspidiotus tuberculatus Laing, 1929, by original designation and monotypy.

The author placed this genus in the Diaspidini. Borchsenius and Williams, 1963, Brit. Mus. (Nat. Hist.) Ent. Bul. 13: 356-357, discussed it and commented on the difficulty of a positive tribal placement.

Allantomytilus Leonardi, 1898, Rir. di Patol. Tea. (1597) (3:45 (205) $-46(206)$.

TYPE-SPECIES : Mytilaspis maideni Maskell, 1897, by monotyps.

This genus may be distinct from relatives such as Lepidosaphes Shimer and Coccomytilus Leonardi as Ferris, 1936a: 20, 24, concluded, but there has been no recent comparative study of its status.

Allococcus Ezzat and McComell, 1956, Md. Agr. Expt. Sta. Bul. A-84:13.

TYPE-sPecies: Pscudococcus inamabilis Hambleton, 1935, by original designation.

This genus was established for four species from widels seluarated loealities but all showing relationship to the pseudococcid genus Planococcus Ferris.

Allomyrmococcus Takahashi, 1941, Tenthredo $3: 201$.

TYPE-SPECIES: Allomyrmococcus acariformis Takahashi, 1941, by original designation and monotypy. 
This is an aberrant genus of the Pseudococcidae, which probably associates with some other genera (Hippeococcus Reyne) in a distinct group, well isolated from characteristic pseudococeine forms.

Allopulvinaria Brain, 1920, Bul. Ent. Res. 11: 16.

TYPE-SPECIES : Allopulvinaria subterranea Brain, 1920, by original designation and monotypy.

The author's implied relationships (in generic key) were with Pulvinaria Targioni-Tozzetti and Protopulvinaria Cockerell in the Coccidae (str.).

Allotrionymus Takahashi, 1958, Univ. Osaka (Prefecture) Bul. (ser. B) (1957) $7: 4-5$.

TYPE-SPECIES : Allotrionymus elongatus Takahashi, 1958, by original designation and monotypy.

According to the describer, this genus is related to Trionymus Berg in the Pseudococcidae.

Aloaspis Williams, 1955, Ent. Soc. South. Africa Jour. 18: 247.

TYPE-SPECIES : Aloaspis mutica Williams, 1955, by original designation and monotypy.

This was placed by the author in the chionaspiform group of genera, presumably Balachowsky's Diaspidini, Diaspidina, chionaspiform group.

Alrococcus Goux, 1941, Marseille Mus. d'Hist. Nat. Bul. [n.v. (v.1 ?)] $1: 69$.

In all subsequent references the author spelled this name Atrococcus, and it is our assumption that the latter spelling was his intended choice and that Alrococcus is a lapsus.

Ambigaspis MacGillivray, 1921, The Coccidae, p. 394.

TYPE-SPECIES: Pseudaonidia lycii Brain, 1919, by original designation and monotypy.

This genus was placed by MacGillivray in the Aspidiotini in association with Lattaspidiotus MacGillivray, Partargionia MacGillivray, and others. Recent workers (Balachowsky, 1958b : 269) have accepted it as valid but have placed it in the Diaspidini.

Amelococcus Marchal, 1904, Soc. Ent. de France Ann. 73: 557, 560. TYPE-SPECIES: Amelococous alluaudi Marchal, 1904, by original designation and monotypy.

Originally suggested for inclusion in the Eriococcinae, this genus actually is identical with, or very closely related to, the genus Cerococcus Comstock in the Asterolecaniidae.

Americoccus MacGillivray, 1921, The Coccidae, p. 78.

TYPE-SPECIES: Matsucoccus fasciculensis Herbert, 1919, by original designation and monotypy.

The type-species of this genus is an obvious Matsucoccus Cockerell so the genus lacks standing. See Morrison 1928: 48. 
Ametrochaspis MacGillivray, 1921, The Coccidae, p. 311.

TYPE-SPECIES: Chionaspis flava Green, 1899, by original designation and monotypy.

Recent authors (Rao, 1949: 59-60) have placed this name as a synonym of Unaspis MacGillivray.

Amonostherium Morrison and Morrison, 1922, U.S. Natl. Mus. Proc. 60, Art. $12($ No. 2407) : 48 .

TYPE-SPECIES : Dactylopius lichtensioides Cockerell, 1897, by original designation and monotypy.

This genus was established for a rather common western U.S. pseudococcid and it possibly can be included in the phenacoccine series of genera.

Amorphococcus Green, 1902, Ent. Monthly Mag. 38: 261.

TYPE-SPECIES: Amorphococcus mesuae Green, 1902, by original designation and monotypy.

This genus was assigned to the Asterolecaniidae by its describer but it has been associated recently by Borchsenius, 1960d: 221, 223, with Lccaniodiaspis Signoret and other genera in the Lecaniodiaspididae.

Ampelocecis Amyot, 1847, Soc. Ent. de France Ann. (ser. 2) 5: 502.

This was proposed as a uninomial replacement for Coccus vitis Linnaeus; hence it is without status from the original publication. Lindinger, 1932f: 199, discussed an "Ampelocecis vitis Amy. $1847=$ ? Phenacoccus aceris," so the name might have status of sorts from 1932.

Anamaspis Leonardi, 1906, Portici R. Scuola Super. di Agr. Ann. (ser. 2) $6: 4,22$.

TYPE-SPECIES : Leucaspis loewi Colvée, 1882, by monotypy.

Some recent workers (Ferris, 1937d: 104, Balachowsky, 1953g: 842) have regarded this name as a synonym of Leucaspis Targioni-Tozzetti.

Anamefiorinia Leonardi, 1906, Redia (1905) 3:17, 48.

TYPE-SPECIES : Fiorinia casuariniae Maskell, 1897, by subsequent designation by MacGillivray, 1921: 372.

Recent workers (Balachowsky, 1953g: 842 ) have accepted this as a valid genus related to Fiorinia Targioni-Tozzetti.

Anaparaputo Borchsenius, 1962, Akad. Nauk SSSR Zool. Inst. Trudy $30: 224$.

TYPE-SPECIES: Anaparaputo liui Borchsenius, 1961, by original designation and monotypy.

The describer placed this genus close to Paraputo Laing in the Pseudococcidae, Planococcini. 
Anapulvinaria Borchsenius, 1952, Akad. Nauk SSSR Zool. Inst. Trudy 12: 296, 300.

TYPE-SPECIES : Pulvinaria pistaciae Bodenheimer, 1926, by original designation and monotypy.

The describer, 1957: 203, assigned this genus to the Coccidae (str.), Coccinae, Pulvinariini.

Anaspidiotus Borchsenius and Williams, 1963, Brit. Mus. (Nat. Hist.) Ent. Bul. $13: 381$.

TYPE-SPECIES : Aspidiotus immaculatus Green, 1904, by original designation and monotypy.

The authors placed this genus in the Aspidiotini related to Aspidiotus Bouché.

Anatolaspis Bodenheimer, 1949, The Coccoidea of Turkey, Ankara. Guney Pub. Office No. 670 : 29, 39, 101 (in Turkish) ; 1951, Ent. Ber. 13: 330 (in English).

TYPE-SPECIES : Anatolaspis abidini Bodenheimer, "1941," by original designation and monotypy.

The describer's action in apparently dating the type-species from 1941 is confusing. We have found no evidence that the name appeared in print that year. We accept the appearance of the name plus an adequate illustration of the morphological characteristics of the type-species in 1949 as evidence of its publication in that year, and note that the author, in his 1951 reference, dated the genus from 1949. Balachowsky, 1953g: 827, concluded that the type-species is identical with Parlatoreopsis longispina (Newstead), 1911, and that the name Anatolaspis is a synonym of Parlatoreopsis Lindinger. We concur in this conclusion.

Ancepaspis Ferris, 1920, Canad. Ent. 52:32.

TYPE-SPECIES : Protodiaspis tridentata Ferris, 1919, by original designation.

This was originally described as a peculiar diaspidid genus. Ferris, 1936a: 18, placed it in the Phoenicococcinae, which he accepted as a subfamily of the Diaspididae.

Andaspis MacGillivray, 1921, The Coccidae, p. 275.

TYPE-SPECIES: Mytilaspis flava var. hawaiiensis Maskell, 1894, by original designation.

The species assigned to this genus have been reviewed by Rao and Ferris, 1952: $17-32$.

Anemolus Mahdihassan, 1934, Current Sci. [India] 3:261.

We are uncertain as to the status of this name. Only one species, indicus, is mentioned in association with it, and Mahdihassan did not give the author of the specific name. An indicus has been published as a nomen nudum in association with Anomalococcus Green, first by Fletcher, 1917, Second Ent. Meeting, Pusa, Rpt. of Proc. : 275, then by Ramakrishna Ayyar, 1919: 627, who described the gross appearance of the insect. Our opinion is that this name is a lapsus for Anomalococcus Green. 
Angulaspis "MacGillivrar," 1937, Lindinger, Ent. Jahrb. 46 : 179.

We find no eridence that MacGillirrar proposed this name, and therefore conclude that it is a misspelling of Augulaspis MacGillivray.

Anisococcus Ferris, 1950. Atlas of the Scale Insects of North America (ser. 5) [v. 5]: 26.

TYPE-SPECIES : Dactylopius crawii Coquillet, 1899, by original designation.

The author assigned six species to this genus. Its indicated relationships were with Pseudococcus Westrood, sensus latus.

Annulaspis Ferris, 1938, Atlas of the Scale Insects of North America (ser. 2) [r.2]:SII-154.

TYPE-SPECIES : Annulaspis polygona Ferris, 1938, by original designation and monotrpy.

When he described this genus, the author indicated a relationship with the Oronaspis Leouardi group of genera. Balachowskr, 1953g: 72S, assigned it to the Rugaspidiotina.

Annulicoccus Morrison, 1945, Wash. Acad. Sci. Jour. 35 : 39.

A lapsus for Annulococcus James.

Annulococcus James, 1936, Roy. Ent. Soc., London, Trans. 85 : 209.

TYPE-SPECIES: Annulococcus ugandaensis James, 1936, by original designation and monotypy.

According to Morrison, 1945: 40, this genus associates with a group of mealybug genera having Heterococcus Ferris as its best known representative.

Anomalococcus Green, 1902, Ent. Monthly Mag. 38:260.

TYPE-SPECIES: Anomalococcus cremastogastri Green, 1902, by original designation and monotypy.

The describer assigned this genus to the Asterolecaniinae. The latest comment on the genus (Borchsenius, 1960d: 221, 223) associated it closels with Lecaniodiaspis Signoret.

Anomosterium Gómez-Menor, 1960, Eos 36:201.

A lapsus for Amonostherium Morrison and Morrison.

Anomostherium Balachowsky, 1932, Encyc. Ent. (ser. 1) 15: XXXIX.

A lapsus for Amonostherium Morrison and Morrison.

Anophococcus Balachowsky, 1954, Soc. Ent. de France Bul. 59: 61.

TIPE-SPECIES : Eriococcus inermis Green, 1915, by original designation.

The author included fire species in this genus and indicated a close relationship with Erionorms Targioni-Tozzetti. The name appears to be a srnonsm of Grenisca. Borchsenius, 1948: 502, since both genera have the same trpe-species. 
Anoplaspis Leonardi, 1898, Riv. di Patol. Veg. (1897) 6:47 (207).

TYPE-SPECIES : Mytilaspis metrosideri Maskell, 1880, by monotypy.

Ferris, 1920a : 63-64, reviewed the confusion caused by Leonardi's double use of this name (see Anoplaspis Leonardi, 1900) and indicated the necessity to base the genus on Mytilaspis metrosideri Maskell. This action seems acceptable under the conditions of Article 16(a) (v) of the 1961 Code. This species was redescribed by Morrison and Morrison, 1922: 109. Balachowsky, 1954e: 171, assigned the genus to his Diaspidina, group II, chionaspiform.

Anoplaspis Leonardi 1900, Riv. di Patol. Veg. 8:344.

TYPE-SPECIES : Aspidiotus (Odonaspis) bambusarum Cockerell, 1898, by original designation and monotypy.

Leonardi unequivocally rejected his 1898 application of this generic name and applied it anew to an entirely different coccid. This new application has been generally rejected, and MacGillivray, 1921, proposed the new generic name Berlesaspidiotus, using the same type-species.

Anotaspis Ferris, 1941, Atlas of the Scale Insects of North America (ser. 3) [v. 3] : SIII-269.

TYPE-SPECIES : Anotaspis particula Ferris, 1941, by original designation and monotypy.

The describer placed this genus in the Diaspididae, Diaspidini, without more precise assignment. Balachowsky, 1953g: $842,1958 \mathrm{~b}: 335$, assigned it to his Leucaspidina.

Anothococcus Ferris, 1955, Atlas of the Scale Insects of North America $7: 94,148$.

A lapsus for Anophococcus Balachowsky. Ferris also mistakenly cited gouxi Balachowsky, 1954, as the type-species.

Antakaspis Mamet, 1959, Inst. Sci. de Madagascar, Mém. (195̃9) (Sér. E. Ent.) $11: 465-466$.

TYPE-SPECIES: Antakaspis terminalis Mamet, 1959, by original designation and monotypy.

The describer proposed a new tribe, Antakaspidini, in the Diaspididae for the reception of this genus.

Antandroya Mamet, 1959, Inst. Sci. de Madagascar, Mém. (1959) (Sér. E. Ent.) 11:410-412.

TYPE-SPECIES : Antandroya euphorbiae Mamet, 1959, by original designation.

The describer placed this genus in the Coccidae (str.).

Antecerococcus Green, 1901, Linn. Soc. N.S. Wales, Proc. (1900) 25 : 560 .

TYPE-SPECIES : Antecerococcus punctiferus Green, 1900, by monotypy.

$208-496-66-2$ 
Green, 1909a : 305, placed this name as a synonym of Cerococcus Comstock, 1882. Ferris, 1955a: 31, accepted this placement. Borchsenius, 1960d: 104, however, differentiated between Cerococcus Comstock and Cercococcus Scott, and associated Antecerococcus tentatively in a group with them.

Antonia Signoret, 1872, Soc. Ent. de France Ann. [Bul. Ent.] (ser. 5) 2:xxxvi; 1875, [Bul. Ent.] (ser.5) 4 : ccxx.

TYPE-SPECIES : Antonia purpurea Signoret, 1872, by monotypy.

Signoret's usage of Antonia was preoccupied, according to Neave, 1939, Nomen. Zool. I : 235, by use in the Diptera in 1856 and in the Hemiptera in 1864, and was therefore invalid in the Coccoidea. See Antonina Signoret for other comment.

Antoniella Neave, 1950, Nomen. Zool. V:18.

A misspelling of Antoninella Kiritschenko.

Antonina Signoret, 1875, Soc. Ent. de France Ann. (ser. 5) 5: 24.

TYPE-SPECIES : Antonia purpurea Signoret, 1872, by monotypy.

Although no statement to that effect was located, we have assumed that Signoret proposed this name on discovery of the earlier usages of Antonia in other groups. The author suggested relationships with Gossyparia Signoret, Capulinia Signoret, and Eriococcus Targioni-Tozzetti. Today it is well established as an aberrant genus in the Pseudococcidae.

Antoninella Kiritschenko, 1938, Konowia $16: 233$.

TYPE-SPECIES : Antoninella inaudita Kiritschenko, 1938, by monotypy.

Both the original describer and Borchsenius, $1950 \mathrm{~b}$ : 173, indicated a relationship to Rhizoecus Künckel d'Herculais in the Pseudococcidae for this genus.

Antoninella Sulc, 1944, Seske Zool. Společ. Vĕst. (1944) $9:$ 148-149.

TYPE-SPECIES: Antonina sulci Green, 1934, by original designation and monotypy.

This generic name is clearly preoccupied by Antoninella Kiritschenko, 1938. From the incomplete study of casuarinae Maskell, the type-species of Sphaerococcus Maskell, 1892, made by Morrison and Morrison, 1922: 35, it appears that Antonina sulci has some relationship to the Maskell genus, but the evidence currently available is too incomplete to permit placing the Sulc name as a synonym of Sphaerococcus Maskell.

Antoninoides Ferris, 1953, Atlas of the Scale Insects of North America $6: 300$.

TYPE-SPECIES: Antonina parrotti Cockerell, in Fernald, 1903b, by original designation and monotypy.

The author indicated close relationships with Antonina Signoret for this genus.

Aoinidomytilus Michelmore, 1955, Uganda Dept. Agr. Ann. Rpt. for $1954: 117$.

A lapsus for A onidomytilus Leonardi. 
Aonidia Targioni-Tozzetti, 1868, (separate) Soc. Ital. di Sci. Nat. Atti $11: 43 ; 1869,11: 735$.

TYPE-SPECIES : Aonidia purpurea Targioni-Tozzetti, 1868, a name substituted by the author for Aspidiotus lauri Bouché, 1833.

This genus has retained its present concept, although soon after its first publication Signoret, in his early monographic work, made some attempt to associate Aonidia with Coccus aonidum Linnaeus, 1758. Balachowsky, 1958b: 232, proposed assignment to Aonidina, Aspidiotini, Diaspidinae, Diaspididae.

Aonidiella Berlese and Leonardi, 1895, in Berlese, Riv. di Patol. Veg. (1896) $4: 77,83$.

TYPE-SPECIES : Aspidiotus aurantii Maskell, 1879, by monotypy.

The authors did not associate this species directly with their new genus when this was described, although the combination was mentioned in a footnote discussing Targioni-Tozzetti's action in assigning the species to his genus Aonidia. In recent years this genus has acquired full status as a segregate within the Aspidiotinae. McKenzie reviewed the inclusions in 1938 and added supplementary information in 1942b, 1946, and 1953, covering a total of 22 species. Balachowsky, 1956 : 22-49, reviewed the 19 African species of the genus.

Aonidomytilus Leonardi, 1903, Portici R. Scuola Super. di Agr. Ann. (1904) (ser. 2) 5:4,102.

TYPE-SPECIES: Mytilaspis albus var. concolor Cockerell, 1893, by monotypy.

The describer presented this first as a subgenus (p. 4), later as a genus (p. 102), indicating a relationship with Mytilaspis (i.e., Lepidosaphes Shimer). Subsequent workers, including Ferris, 1942: SIV-446-448, have accepted the genus as a valid unit and have assigned several species to it. Balachowsky, 1954e: 23, included it in his Lepidosaphedina but listed maideni Maskell as the type-species.

Apezococcus Ferris, 1955, Atlas of the Scale Insects of North America $7: 78-79$.

TYPE-SPECIES : Apezococcus idiastes Ferris, 1955, by original designation and monotypy.

The author placed this genus in his Eriococcidae. Hoy, 1963, New Zeal. Dept. Sci. and Indus. Res. Bul. 150 : 6, agreed.

Apiococcus Hempel, 1900, Rev. Mus. Paulista [Sao Paulo] 4: 401.

TYPE-SPECIES: Apiococcus gregarius Hempel, 1900, by original designation.

The author assigned this genus to the Dactylopiinae (of the Fernald Catalogue, 1903b). Ferris, 1957c : 84, placed it in the Eriococcidae, as did Hoy, 1963, New Zeal. Dept. Sci. and Indus. Res. Bul. 150: 6 .

Apiomorpha Rübsaamen, 1894, Berlin. Ent. Ztschr. 39 : 201, 204.

TYPE-SPECIES : Brachyscelis pileata Schrader, 1863, designated by Lindinger, $1937: 179$.

This name was substituted by Rübsaamen for the name Brachyscelis Schrader, 1863, which was preoccupied by use in 1834 in the Coleoptera. In spite of the long 
and involved history of this classificatory unit, we have found no type indication prior to that presented in Lindinger's 1937 list of coccid genera. Rübsaamen did not himself refer to pileata. Ferris, $1957 \mathrm{~b}: 66,1957 \mathrm{c}: 84$, assigned the genus to the Eriococcidae. Hoy, 1963, New Zeal. Dept. Sci. and Indus. Res. Bul. 150 : 6 , agreed.

\section{Apterococcus Newstead, 1898, Ent. Monthly Mag. 34:97.}

TYPE-SPECIES : Ripersia fraxini Newstead, 1891, by monotypy.

It seems reasonably established that this name is a synonym. Lindinger, 1937: 179, and Borchsenius, 1949: 365, concluded that Newstead's species is identical with Chermes (?) fraxini Kaltenbach, 1860, which Nitsche, 1895: 1249, made the type of his genus Pseudochermes. Ferris, 1955a: 178, reviewed the problem of proper association but was unable to arrive at an acceptable conclusion. Later, he, 1957e: 88, tentatively followed Lindinger and Borchsenius in placing it as a synonym of Pseudochermes, which he assigned to his Eriococcidae, but raised a question as to the separation of this and Gymnococcus Douglas (now Ovaticoccus Kloet on account of preoccupation of Gymnococcus). We are not able to offer a critical opinion on this problem.

Apteronidia Berlese, 1895, Riv. di Patol. Veg. (1896) 4:80.

TYPE-SPECIES : Aonidia blanchardi Targioni-Tozzetti, 1892, by original designation and monotypy.

The author first proposed this genus in a footnote discussion of TargioniTozzetti's assignment of certain species to the genus Aonidia Targioni-Tozzetti. It has had a varying status as a coccidological unit since its proposal, with most workers placing the name as a synonym of Parlatoria Targioni-Tozzetti, 1868. These, among more recent coccid students, include Stickney 1934a, Ferris 1936a, Morrison 1939a, McKenzie 1945, Borchsenius 1950b, and Balachowsky 1953g. In contrast, Lindinger, 1937: 179, recognized the genus as a ralid zoological unit and placed several proposed coccid generic names in synonymy under it. Ghauri, 1962: 21t, on the basis of his study of adult male diaspidids, suggested the validity of its generic separation from Parlatoria, but did not actually make this formal separation.

Araucaricoccus Brimblecombe, 1960, Queensland Jour. Agr. Sci. 17: 183.

TYPE-SPECIES: Araucaricoccus queenslandicus Brimblecombe, 1960, by original designation and monotypy.

The author suggested a relationship to Matsucoccus Cockerell in the Margarodidae for this genus.

Archangelskaia Bodenheimer, 1951, Ent. Ber. 13 : 331.

TYPE-SPECIES : Parlatoria ephedrae Lindinger, 1911, by original designation and monotypy.

The describer indicated that this genus is related to Parlatoria TargioniTozzetti. Balachowsky, 1953g: 773, 793, placed the name as a synonym of Parlatoria.

Archaspis Bodenheimer, 1943, Iraq. Dir.-Gen. Agr. Bul. 28: 25. TYPE-SPECIES : Archaspis ephedrae Bodenheimer, 1943, by monotypy. 
Since the author of this 1943 genus did not himself definitely fix a typespecies for it, the genus can have no standing under Article 13(b) of the 1961 Code. Otherwise, the genus has the identical foundation for acceptance available for many other coccid genera. The author suggested a relationship to the genus Conchaspis Cockerell, but both Balachowsky, 1948b: 257, 259, and Mamet, $1954 \mathrm{~b}: 193$, in his monograph of the Conchaspididae, disagreed, considering that the insect is either an aberrant or an immature diaspidine coccid.

Arctorthezia Cockerell, 1902, Entomologist 35: 114, 259.

TYPE-SPECIES: Orthe:ia occidentalis Douglas, 1891, by subsequent designation by the author (p. 259).

Originally set up as a new "section" of the genus Orthesia Bosc d'Antic, this unit was subsequently raised first to subgeneric, and then to generic standing by Morrison, 1925: 143, 1952: 53, who reviewed it with other ortheziid genera and species.

Artemicoccus Balachowsky, 1953, Soc. des Sci. Nat. du Maroc, Bul. 33 (trimest. 3) : 147 .

TYPE-SPECIES : Centrococcus bispinus Borchsenius, 1949, by original designation.

The author proposed this genus for three species previously assigned to Centrococcus Borchsenius, all living on Artemisia.

Artemisaspis Borchsenius, 1949, Akad. Nauk SSSR Dok. (n.s.) 64: $735-736$.

TYPE-SPECIES: Artemisaspis artemisiae Borchsenius, 1949, by original designation.

The author placed this genus in the Diaspidini, and indicated a close relationship to Chionaspis Signoret. Balachowsky, 1953g: 751 (footnote), placed the name in synonymy with Rhizaspidiotus MacGillivray, and since artemisiae was already included in the latter genus, proposed the new name Rhizaspidiotus mesasiaticus for artemisiae Borchsenius. Borchsenius and Williams, 1963, Brit. Mus. (Nat. Hist.) Ent. Bul. 13: 357, rejected this action and considered Artemisaspis a distinct and valid genus.

Arundaspis Borchsenius, 1949, Akad. Nauk SSSR Dok. (n.s.) 64: 735,737 .

TYPE-SPECIES : Arundaspis secreta Borchsenius, 1949, by original designation and monotypy.

The describer placed this genus in the Odonaspidini. Balachowsky, 1951: 650, 670 , placed the name in synonymy with Rhisaspidiotus MacGillivray in the Aspidiotini, Targionina of his scheme of classification. Borchsenius and Williams, 1963, Brit. Mus. (Nat. Hist.) Ent. Bul. 13: 381, rejected this opinion and considered the genus to be distinct and allied to the genera Aspidiella Leonardi, Rhizaspidiotus MacGillivray, Remotaspidiotus MacGillivray and Eremiaspis Balachowsky in the Aspidiotini. Lindinger, 1957: 545, indicated that the typespecies was identical with Dycryptaspis (i.e., Odonaspis of authors) secreta (Cockerell), but we believe that his opinion was based on a misunderstanding of the Borchsenius description. 
Ascelis Schrader, 1863, Ent. Soc. N.S. Wales Trans. 1 : 6.

TYPE-SPECIES : Ascelis praemollis Schrader, 1863, by monotypy.

The describer associated this genus with Apiomorpha Rübsaamen and Opis. thoscelis Schrader. Ferris, 1957c: 84. included it in the Eriococcidae, and Hor, 1963. New Zeal. Dept. Sci. and Indus. Res. Bul. 150: 6, placed it there tentatirely.

Asphodelococcus Morrison, 1945, Wash. Acad. Sci. Jour. 35 : $41-42$.

TYPE-SPECIES : Ripersia asphodeli Bodenheimer, 1927, by original designation and monotypy.

The indicated assignment for this genus was within the Heterococcus Ferris complex of the Phcnacoccus Cockerell series of genera in the Pseudococcidae.

Asphodeloripersia Bodenheimer, 1953, Istanbul Unir. Facult. des Sci. Rev. (ser. B) 18:164.

We believe that this is a lapsus for Asphodelococcus Morrison since the associated figure on page 124 is labeled Asphodelococcus asphodeli.

Aspidaspis Ferris, 1938, Microentomology 3: 45: 1938, Atlas of the Scale Insects of North America (ser. 2) [v. 2] : SII-181.

TYPE-SPECIES : Aspidiotus densiflorae Bremner, 1907, by original designation.

The author included five species here and indicated a relationship with Aspidiotus Bouché (str.). Balachorsky, 1950b: 545, recognized the genus for the Palearctic area, assigned three species to it, and placed it in the Aspidiotini.

Aspidatus Kirchner, 18ว6, Lotos $6: 218$.

A lapsus for Aspidiotus Bouché.

Aspidiatus Breyer, 1862. Soc. Ent. de Belge Ann. 6:97.

A lapsus for Aspidiotus Bouché.

Aspidiella Leonardi, 1898, Rir. di Patol. Veg. (1897) 6: 50 (210), $60(220)$.

TYPE-SPECIES: Aspidiotus sacchari Cockerell, 1894, by original designation.

Originally presented as a new subgenus of Aspidiotus Bouché, the author included here a collection of aspidiotine forms now widely scattered in several genera. Ferris, 1937c: 50, 53, accepted this as a ralid zoological unit. Bala(howskr, 1958b: 282-286. accented the genus for the species hartii (Cockerell) and sacchari Cockerell.

Aspidioides MacGillivray, 1921, The Coccidae, p. 387.

TYPE-SPECIES: Aspidiotus corohiae Maskell, 1891, by original designation.

Lindinger, 1937: 179, and Ferris, 1937c: 50, both used this spelling, which first appeared in a key on page 387 . On subsequent pages $(406,477)$ in his book, MacGillivray presented the spelling Aspidoides, but this presumably is to be rejecterl berause of definite acceptance of the initial spelling. Ferris, 1941e: 42, suggested the possibility that the type-species would assign to the genus Aspidiella Leonardi. Borehsenius and Williams, 1963, Brit. Mus. (Nat. IIist.) Ent. I3ul. 13: 3\$4. considered the resemblance to 4 spinticlla superficial and 
regarded the genus distinct pending further study of the New Zealand and Australian species. They suggested Monaonidiella MacGillivray as its nearest genus.

Aspidioproctus Sasscer, 1912, U.S. Dept. Agr., Bur. Ent., Tech. Ser. $16: 83$.

A lapsus for Aspidoproctus Newstead.

Aspidiotes Bouché, 1844, Stettin. Ent. Ztg. 5 : 294.

A lapsus for Aspidiotus Bouché.

Aspidiotus Bouché, 1833, Naturgeschichte der Schädlichen und Nützlichen Garten Insekten : 52; 1834, Naturgeschichte der Insekten, p. 9.

TYPE-SPECIES : Aspidiotus nerii Bouché, 1833, by subsequent designation of Leonardi, $1897: 285$.

Ferris, 1941e: 39, reviewed this genus, attempted to list and, where indicated by current ideas, to reassign all species that had ever been placed in the genus. He restricted the inclusions to a comparatively few species. Subsequently he, $1946: 42-44$, added supplementary notes to his previous review.

In post-Fernald Catalogue, 1903b, literature involving the type-species of Aspidiotus, this has been presented consistently, except for Ferris, 1941e, as "A. hederae (Vallot)" or as "A. nerii Bouché=A. hederae (Vall.)." So far as we have been able to ascertain, the name " $C$. hederae Vallot 1829 " is a nomenclatorial artifact that did not exist prior to presentation in Signoret, 1868: 513, 856 . The name is not presented in Vallot, 1829, where only one scientific name, Coccus mesembryanthemi Vallot, appears, and a search through other volumes of the "Mém. Acad. Dijon" has produced no other paper in which hederae is proposed by Vallot. We know of no recent critical review of the question of the identity of Aspidiotus hederae as described by Signoret, 1869: 122, and Aspidiotus nerii Bouché, as this has been interpreted since its original description. The first hint of synonymy appears to be the suggestion of the possibility by Cockerell, 1894, Insect Life $6: 327$, and $1894 \mathrm{w}: 211$. The first flat assignment of nerii in synonymy under hederae appears to hare been made by Leonardi, 1898c: 71, where Signoret's "C. hederae Vall." is also converted into Chermes hederae Vallot, 1829. This was accepted in the Fernald Catalogue, 1903b, and apparently universally thereafter, except for Ferris, 1941e: 39, who said, "type nerii which is supposed to be hederae." There are so many references to Aspidiotus hederae in the literature, both as a ralid species and as the proper name for the coccid which Bouche called neri-we have records of around 1,000 such citations-that we hesitate to suggest any disruption of the existing stability. Howerer, if priority is to stand as one of the foundation stones of zoological nomenclature, it appears to us that this is one instance in which it is necessary to apply its requirements, and to accept the name nerii for the type of Aspidiotus.

Aspidistus Cockerell, 1899, New York Ent. Soc. Jour. 6 : 258-259.

A lapsus for Aspidiotus Bouché.

Aspidites Berlese and Leonardi, 1896, Riv. di Patol. Veg. 4: 349-350.

TYPE-SPECIES: Aspidiotus rapax Comstock, 1881 (A. camelliae Sign. ?), by original designation.

This name was preoccupied in Reptilia, 1877, and in Mollusca, 1895, according to Neave, 1939, Nomen. Zool. I : 319. Cockerell, 1897 (in Leonardi, 1897a), 
discorered the Mollusean preoccupation shortls after the presentation of Aspidites br Berlese and Leonardi and suggested the name Hemiberlesia as a substitute.

Aspiditus Lindinger, 1910, Ztschr. f. Wiss. Insektenbiol. $6: 192$.

A lapsus for Aspidiotus Bouchê.

Aspidoides MacGillivray, 1921, The Coccidae, pp. 406, 47 .

See discussion under Aspidioides MacGillirray.

Aspidonymus Brimblecombe, 1957, Queensland Jour. Agr. Sci. 11: 283.

TYPE-SPECIEs: Aspidonymus wooduardi Brimblecombe, $195 \bar{\imath}$, bs original designation and monotypy.

The author suggested relationship with Pseudaonidia Cockerell.

Aspidoproctus Nerstead, 1901, London Zool. Soc. Proc. (1900) 62 : 948.

TYPE-SPECIES: Walkeriana pertinax Newstead, 1901, by original designation and monotspy.

Nerstead's presentation of this name was curionsly contradictort. The trpespecies was actualls presented in Walkeriana Signoret. The generic name Aspidoproctus was onls presented in an appended discussion of the original intent of the author, and was discarded in his final action, which we interpret as presentation in synonymy (1961 Code, Article 11(d)). The generic name Aspidoproctus has had long use, howerer, and was ralidated in Opinion 268 (1954) : 397 , of the International Commission on Zoological Nomenclature. For its relationships in the Coccoidea see Morrison, 1928: 151.

Aspisarcus "Yeuport" Walker, 1852, List of the Specimens of Homopterous Insects in the Collection of the British Musemm. Pt. 4:10s8.

TYPE-SPECIES: Aspisarcus eucalypti Newport [no date], nomen nudum, by monotypy.

Although presented by Walker as indicated, we hare not succeeded in finding earlier references to Nerport's proposal of the names, and follow other coccid workers in regarding both genus and species as nomina nuda. Fernald Catalogue, 1903b: [330], suggested "A Psrllid ?" but since no description of ans sort accompanied the Walker presentation, we do not understand the basis for the suggestion.

Assymetraspis Lindinger, 193-. Ent. Jahrb. 46: 180.

A lapsus for Asymmetraspis MacGillirrar.

Asterilecanium Lindinger, 1929, Ent. .Tahrb. $32: 146$.

A misspelling of Asterolecanium Targioni-Tozzetti.

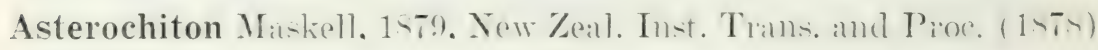
$11: 214$.

Although described as a coccoid genus, this is reported to be an alerrolid. 
Asterococcus Borchsenius, 1960, Akad. Nauk SSSR Zool. Inst. (n.s. 77) $8: 113-115$.

TYPE-SPECIES: Asterococcus schimae Borchsenius, 1960, by original designation.

This genus was established for four species, and was placed in close association with Cerococcus Comstock.

Asterodiaspis Signoret, 1877, Soc. Ent. de France Ann. [Bul. Ent.] (ser. 5) 6 : ccix.

TYPE-SPECIES : Aonidia ilicicola Targioni-Tozzetti, 1888, misidentified by Signoret as Asterolecanium quercicola (Bouché), 1851. See Russell, 1941: 109, for a report on her examination of Signoret specimens.

Russell, 1941: 4, placed this name as a synonym of Asterolecanium TargioniTozzetti. Borchsenius, 1950a: 781, 1960d; 174, recognized it as a valid genus and included 17 species in it.

Asterolecanium Targioni-Tozzetti, 1868, (separate) Soc. Ital. di Sci. Nat. Atti 11:41;1869, $11: 734$.

TYPE-SPECIES : Coccus aureus Boisduval, 1868, by monotypy.

Targioni-Tozzetti presented aureus Boisduval as a synonym of "Asterolecanium aureum nob." Coccus aureus Boisduval is at present considered to be a synonym of Lecanium epidendri Bouché, 1844.

Russell, 1941, considered Asterolecanium to be a relatively homogeneous genus containing (in 1941) 160 species and varieties. Borchsenius, 1960d: 131, recognized 11 genera in the complex and restricted Astcrolecanium to 3 species.

Asymmetraspis MacGillivray, 1921, The Coccidae, p. 311.

TYPE-SPECIES : Chionaspis distorta Newstead, 1917, by original designation.

The author placed this genus in his Diaspidini in association with several other new genera. Hall, 1946a: 503-504, accepted it as a valid genus.

Atriplicia Cockerell and Rohwer, 1909, Ent. Soc. Wash. Proc. (1908) 10: 169 .

TYPE-SPECIES : Atriplicia gallicola Cockerell and Rohwer, 1909, by monotypy.

Neave, 1939, Nomen. Zool. I : 351, credited this genus to Cockerell only, but the original paper indicated that joint authorship existed. Lindinger, 1937: 180, presented a thoroughly confusing “Atriplicia Cockerell 1893." Ferris, 1955a : 94, placed the name in synonymy under Eriococcus Targioni-Tozzetti, but at the same time presented distinctive, descriptive information of a sort that has been used by some workers for generic recognition. Hoy, 1963, New Zeal. Dept. Sci. and Indus. Res. Bul. 150 : 6, restored the genus to full value.

Atrococcus Goux, 1941, Mus. d'Hist. Nat. Marseille Bul. [n.v. (v. 1 ?)] (1) : 69 .

TYPE-SPECIES: Atrococcus melanovirens Goux, 1941, by original designation.

The author first established this as a subgenus of Pseudococcus Westwood, but later in the same paper treated it as a genus. Williams, 1962: 8, accepted the genus for three British species and noted that North American Spilococcus Ferris, 1950, and Chorizoccus McKenzie, 1960, show a close relationship to it. 
Augulaspis MacGillirray, 1921, The Coccidae, pp. 309, 353.

TYPE-SPECIES: Chionaspis nudata Newstead, 1911, by original designation and monotypy.

The author placed this genus in his Diaspidini in association with Phenacaspis Cooley and Cockerell and related genera. Hall, 1946a : 504, used it as valid in his discussion of African diaspidine coccids.

Aulacaspis Cockerell, 1893, Inst. Jamaica Jour. 1: 180.

TYPE-SPECIES: Aspidiotus rosae Bouché, 1834, by restriction by Newstead, 1901b: 168, through his transfer of boisduvalii Signoret, 1869, and bromeliae (Kerner), 1778, originally included by Cockerell, from Aulacaspis back into Diaspis.

Scott, 1952: 33-60, reviewed this genus and indicated proper retentions in it and disposal of species not correctly assigned. Balachowsky, 1954e: 163, placed it in his Diaspidina, diaspiform.

Aulacispis King, 1902, Psyche 9: 401.

A lapsus for Aulacaspis Cockerell.

Auloicerya Morrison, 1923, in Morrison and Morrison, 1923, U.S. Natl.

Mus. Proc. 62, Art. 17 (No. 2463) : 22.

TYPE-SPECIES : Icerya rosae var. australis Maskell, 1894, by original desig. nation.

Morrison, 1928: 211, placed this genus in the Iceryini, Monophlebinae, Margarodidae.

Aulycerya Castel-Branco, 1952, Estudos de Zool. An. 7 :23.

A lapsus for Auloicerya Morrison.

Aumyrmococcus Gonzales Mendoza and Valenzuela, 1955, Agricultura Tropical 11: 593.

A lapsus for Eumyrmococcus Silvestri.

Austrolichtensia Cockerell, 1902, Ann. and Mag. Nat. Hist. (ser. 7) $9: 451$.

TYPE-SPECIES: Lecaniodiaspis (?) hakearum Fuller, 1897, by original designation. Later, Fuller, 1899: 457, presented this same species as "Lichtensia hakearum n. sp.," and Cockerell cited this combination as type of his new genus.

Cockerell made no suggestion regarding the probable relationships of this genus beyond placement in the "Lecaniinae." The Fernald Catalogue, 1903b: 142, associated it with the coccid genera that are completely enclosed by a secreted sac.

Austromaskellia Lindinger, 1943, Ztschr. der Wien. Ent. Gesell. 28: 206-207.

TYPE-SPECIES: Maskellia globosa Fuller, 1897, by substitution of Austromaskellia for Maskellia Fuller. 
This substitute for Maskellia Fuller, 1897, was proposed by Lindinger as a result of his discovery that the combination Maskellia zonata "Green" had appeared in print (as a host of hymenopterous parasites) in a paper published by Howard and Ashmead, 1896, U.S. Natl. Mus. Proc. 18: 639. The name also appeared in Dalle Torre, Catalogus Hymenopterorum (1898) 5: 266, and elsewhere in literature on parasitic Hymenoptera. Lindinger assumed, perhaps correctly, that this host species was the one finally described as Antonina zonata Green, 1919a: 175, but the picture appears to be considerably confused by the fact that the pinned parasite specimens discussed by Howard and Ashmead (now present in the U.S. National Museum collections) have attached to the pins the name Pseudococous zonatus for the host. We can provide no explanation for this discrepancy. We do not find in the 1961 Nomenclature Code any requirement for the permanent rejection of nomina nuda, of which Maskellia zonata as presented by Howard and Ashmead, 1896, certainly is an example, and therefore can see no basis for the rejection of Maskellia Fuller, 1897-a genus that stood undisturbed for 46 years.

Austrotachardia Chamberlin, 1923, Bul. Ent. Res. 14: 194.

TYPE-SPECIES : Tachardia angulata Froggatt, 1911 (orthotype), by original designation.

Originally placed only in the Tachardiinae by its describer, this genus was assigned to the Austrotachardiini by the author, 1925: 40, and to the same by Kapur, 1958: [9]. Balachowsky, 1950: 9, assigned it to "Austrotachardinina Chamberlin."

Austrotachardiella Chamberlin, 1923, Bul. Ent. Res. 14: 174, 187.

TYPE-SPECIES: Tachardia rotundata Cockerell and Cockerell, 1903 (orthotype), by original designation.

Balachowsky, 1950: 9, assigned this genus to the Lacciferinina, Lacciferini. Kapur, 1958: [9], assigned it to the Lacciferini.

Baccacoccus Brain, 1920, Bul. Ent. Res. 10: 127.

TYPE-SPECIES : Baccacoccus elytropappi Brain, 1920, by original designation and monotypy.

The author placed this genus as "allied to the Lecaniinae."

Bacococcus Lindinger, 1937, Ent. Jahrb. 46: 180.

An emendation of Baccacoccus Brain, which is not here accepted.

Bakeraspis MacGillivray, 1921, The Coccidae, p. 395.

TYPE-SPECIES : Odonaspis schizostachyi Cockerell and Robinson, 1914, by original designation and monotypy.

Ferris 1937a: 33, 1938a: SII-161, and Balachowsky 1953g: 729, placed this name as a synonym of Odonaspis Leonardi.

Balachowskiella Kaussari, 1955, Rev. de Path. Veg. et d'Ent. Agr. de France 34: 229.

TYPE-SPECIES: Balachowskiella salvadorae Kaussari, 1956, by original designation and monotypy.

The author assigned this genus to the Diaspidinae, Diaspidini. 
Balachowskya Gómez-Menor, 1956, Portici R. Scuola Super. di Agr., Lab. Zool. Gen. e Agr. Bol. 33 : 615.

TYPE-SPECIES: Balachonvskya hispanica Gómez-Menor, 1956, by original designation and monotypy.

The anthor assigned this genus as close to Rhodania Goux in the Psendococcinae. The name was preoceupied by Balachowskya Peyerimhoff, 1928, in the Coleoptera.

Balanococeus Williams, 1962, Brit. Mus. (Nat. Hist.) Ent. Bul. 12: 13,15 .

TYPE-SPECIES : Ripersia scirpi Green, 1921, by original designation.

The author placed this mealybug genus as closest to Kiritshenkella Borchsenius.

Balaspis Hall, 1946, Roy. Ent. Soc., London, Trans. 97 : 505-506.

TYPE-SPECIES: Balaspis faurei Hall, 1946, by original designation and monotypy.

Balachowsky, 1954e: 172, placed this genus in the Diaspidinae, Diaspidina, group II, chionaspiform.

Bambusaspis Cockerell, 1902, Entomologist 35 : 114.

TYPE-SPECIES: Chermes miliaris Boisduval, 1869, by subsequent designation of Sanders, $1906: 3$.

Russell, 1941: 4, placed this name as a synonym of Asterolecanium TargioniTozzetti. Borchsenius, 1950a: 781, accepted the name as standing for a valid genus.

Bantuaspis Balachowsky, 1954, Inst. Pasteur [Paris] Mém. Sci.: 213.

A lapsus for Bantudiaspis Hall. This spelling was also used by Lindinger, $1957: 547$.

Bantudiaspis Hall, 1941, Ent. Soc. South. Africa Jour. 4 : 225-226.

TYPE-SPECIES : Howardia loranthi Hall, 1928, by original designation.

The describer, 1946a: 506, associated this genus with Asymmetraspis MacGillivray in his review of Ethiopian Diaspidini. Balachowsky, 1954e: 213, under the spelling Bantuaspis, suggested a close relationship to Furchadaspis MacGillivray.

Beesonia Green, 1926, Bul. Ent. Res. $17: 55$.

TYPE-SPECIES : Beesonia dipterocarpi Green, 1926, by original designation and monotypy.

Ferris, $1950: 5$, considered this genus unusual and established a new family, the Beesonidae, for it. Later he, 1957b: 66, maintained the family status for the genus but amended the name to Beesoniidae. 
Benaparlatoria Balachowsky, 1953, Rev. de Path. Veg. et d'Ent. Agr. de France 32 : [19]-20.

TYPE-SPECIES : Benaparlatoria moityi Balachowsky, 1953, by original designation and monotypy.

The author assigned this genus to his Parlatorina.

Bergrothia Kraatz, 1888, Deut. Ent. Ztschr. $32: 360$.

TYPE-sPECIES : Westwoodia perrisii Signoret, 1875, by substitution of Bergrothia for Signoretia Kraatz.

This name was proposed as a substitute for Signoretia Kraatz, 1888, preoccupied in Hemiptera by use of Stål, 1860. Bergrothia Kraatz was itself preoccupied in the Coleoptera by use of Reitter, 1884. This zoological unit is currently placed under Trionymus Berg.

Bergrothiella Reitter, 1898, Wien. Ent. Ztg. $17: 54$.

TYPE-SPECIES : Westwoodia perrisii Signoret, 1875, by substitution of Bergrothiella for Bergrothia Kraatz.

This name was proposed to replace the preoccupied name Bergrothia Kraatz, 1888, although it had been proposed, also by Reitter, 1897, Wien. Ent. Ztg. 16: 241, as an erroneous replacement for Bergrothia Reitter, 1884, in the Coleoptera. Bergrothiella currently is placed as a synonym of Trionymus Berg, 1899.

Bergrothula Strand, 1928, Arch. f. Naturgesch. (Abt. A.h. 8 for 1926) $92: 47$.

TYPE-SPECIES : Westuoodia perrisii Signoret, 1875, by substitution of Bergrothula for Bergrothiella Reitter.

Strand proposed this name as a replacement for Bergrothiella Reitter, 1898, noting that he referred to its application in the Coccoidea, and apparently unaware of the 1899 proposal of the name Trionymus by Berg, for this unit. This name currently is placed as a synonym of Trionymus.

Berlesaspidiotus MacGillivray, 1921, The Coccidae, p. 389.

TYPE-SPECIES : Aspidiotus (Odonaspis) bambusarum Cockerell, 1898, by original designation and monotypy.

Recent coccid workers place this name as a synonym of Froggattiella Leonardi.

Berlesaspis MacGillivray, 1921, The Coccidae, p. 274.

TYPE-SPECIES : Mytilaspis spinifera Maskell, 1894, by original designation.

Balachowsky, 1954e: 23, placed this genus in his Lepidosaphedina, Diaspidini.

Berleseaspis Lindinger, 1937, Ent. Jahrb. 46: 180, 196.

An emendation of Berlesaspis MacGillivray which is not here accepted.

Bernardia Ashmead, 1891, Amer. Ent. Soc. Trans. 18: 100.

TYPE-SPECIES : Chermes oleae Bernard, of authors, by subsequent designation, apparently by correspondence; see Marlatt, 1891, Insect Life 4: 150-151.

This genus was proposed in a key to coccid genera, but without any included species. Bernardia is currently accepted as a synonym of saissetia Déplanche, 1859. 
Bigymnaspis Balachowsky, 1958, Mus. Roy. du Congo Belge [Tervuren] Ann. (n.s.) Sci. Zool. $4: 3+2$.

TYPE-SPECnEs: Gymnaspis bilobis Green and Laing. 1923, by original designation and monotyps.

This genus was placed by its author in his Parlatorini, Gymmaspidina, related to Gymnaspis Newstead.

Birchippia Green, 1900, Amm. and Mag. Nat. Hist. (ser. i) 6:450.

TrPE-SPECIES: Birchippia anomala Green, 1900, by original designation and monotsps.

Green. 1901a: 294, concluded that this name was actually a synonym of Lecaniodiaspis Targioni-Tozzetti. The Fernald Catalogne. 1903b: 59, accepted it as ralid. Borchsenius. 1959a : 841, 1960d: 2:3. included it in his Lecaniodiaspididae and suggested the need to restudy the question of its ralidity.

Bodenheimera Bodenheimer, 1953, Istanbul Lnir. Facult. des Sci. Rev. (ser. B) 18:131.

TYPE-SPEcies: Lecanium (Eulecanium) racheli Bodenheimer, 1924, by monoтуру.

This name, suggested br Green in lit.. first appeared in print in the Bodenheimer list of Palearctic Coccidae, 1935: 240, 251. We consider that Bodenheimer gare the genus status by his inclusion of the name in his kes to the Turkish genera of a mealrbug subfamilr, the Antoninae, eren though his generic characterization mas not critically definitive. He described the trpe-species in considerable detail in this paper. We cannot agree with his assignment after an examination of specimens of the species which Dr. Bodenheimer kindly presented to the L.S. National Collection of Coccoidea, but we are not able to suggest a proper assignment for the species from the material arailable to us. We believe that its placement cau result only from a critical studs of fresh material in all stages. Lindinger, 1957 : 547 , claimed that the type-species is identical to Lecanium coryli (L. ), but we do not think that this can be possible.

Boisduvalia Signoret, 18\%, Soc. Ent. de France Amm. (ser. o) 5) : 338.

We hare found no eridence of trpe fixation for this genus as established in the Coccoidea. Signoret, 1822: clvii, noted that he had previousls used Boisduralia for what is currently known as Cerataphis Lichtenstein, an aphid genus, and immediatels replaced it, for the Coccoidea, with the name Oudablis with the same included species. In addition. the name nas alreadr preoccupied br use in the Diptera where it had been established in 1530. For information on the zoological status of the unit represented by this name, see under oudablis.

Boisduvalis Sule, 194t, Leta Soc. Sci. Nat. Morav. 16 (11) : 49.

A lapsus for Boisduvalia Signoret.

Borchseniaspis Zahradnik, 1959, Leta Faun. Ent. Mus. Nat. Pragae $5: 65$.

TYPE-SPECIES : Aspidiotus palmae "Morgan and Cockerell" [actually Cockerell only], 15!)3, hy original designation and monotrpy.

The relationships, ateording to the describer, are with He mibr rexia Corkerell and Abgrallaspis Balachowsky. 
Boreococcus Danzig, 1960, Ent. Obozr. 39 : 172.

TYPE-SPECIES: Boreococcus ingricus Danzig, 1960, bj original designation and monotypy.

The author suggested a relatively close relationship to Annulococcus James, an African genus of the Pseudococcidae, for this genus.

Bouhelia Balachowsky, 1938, Soc. Ent. de France Bul. 43: 37.

TYPE-SPECIES : Bouhelia maroccana Balachowsky, 1938, by original designation and monotypy.

This genus was placed in the Eriococcinae at the time of its description, but was later placed in the Pseudococcini by Balachowsky, 1948b : 253. It belongs in the phenacoccine series of the Pseudococcidae.

Brachiomorpha Ferris, 1957, Microentomology $22: 66$.

From the usage, this seems to be a lapsus for Apiomorpha Riibsaamen.

Brachyscelis Schrader, 1863, Ent. Soc. N.S. Wales Trans. 1:2, 6.

Brachyscelis was preoccupied by usage in the Coleoptera in 1834, and was replaced by Apiomorpha Rübsaamen, 1894.

Brainaspis MacGillivray, 1921, The Coccidae, pp. 390, 427.

TYPE-SPECIES: Aspidiotus kellyi Brain, 1918, by original designation and monotypy.

MacGillivray placed this genus in his Aspidiotini. Ferris, 1938b: 65, after examination of a type specimen of kellyi, concluded that the name was a synonym of Temnaspidiotus MacGillivray, and he, 1952a: 8, reiterated this stand when he described a new species of Temnaspidiotus. Balachowsky, 1956: 132, however, speculated on the probability that kellyi and Ferris' 1952 new species should stand together as distinct from Temnaspidiotus, but took no definite action to revise Brainaspis.

Brevennia Goux, 1940, Soc. d'Hist. Nat. l'A frique du Nord, Bul. 31 : 58.

TYPE-SPECIES: Brevennia tetrapora Goux, 1940, by original designation and monotypy.

The describer erected this as a subgenus of Ripersia Signoret. Borchsenius, 1949: 270, accepted it as a valid genus and placed it in the phenacoccine series of the Pseudococcidae.

Brevicoccus Hambleton, 1946, Rev. de Ent. [Rio de Janeiro] 17:10. TYPE-SPECIES: Brevicoccus clavisetosus Hambleton, 1946, by original designation and monotypy.

The describer placed this genus in the rhizococcine series of the Pseudococcidae.

Caelostoma Maskell, 1884, New Zeal. Inst. Trans. and Proc. (1883) 16 : 141 .

From the context we believe this to be a printer's error for Coelostoma Maskell. In any circumstance the name is preoccupied by Agassiz's use of it in 1846 as a 
replacement for Coctostoma Brullé. 183.j. Lindinger. 1937 : 181. charged Cockrell with the use of this misspelling.

Caia Williams, 1963, Brit. Mus. (Nat. Hist.) Ent. Bul. 15: 26.

TYPE-SPECIES: Caia quernea Williams, 1963, by original designation and monotyps.

The author referred this genus to the Lepidosaphes Shimer series of the Diaspidini with close affinities with Andaspis MacGillirras.

Calicoccus Balachorskr, 1959, Rer. Acad. Colombiana 10:839.

TYPE-SPECIES: Calicoccus guazumae Balachowsky, 1959, by original designation and monotrpr.

The describer placed this genus in the Pseudococcidae, related to Hypogeococcus Rau.

Calimmata O. G. Costa. 1835,,$^{4}$ Fauna del Regno di Napoli. Famiglia de' Coccinigliferi, o de' Gallinsetti. Emitteri Napoli, p. 2.

Costa used this particular spelling in a footnote on page 2 for the segregate from the genus Coccus sens. lat. which he had called Calymmata in 1826: later in the paper, p. 8, he substituted still another name, Calypticus, for Calimmata. We hare found no eridence that Calimmata has $\in$ rer had standing in the circeoidea, although Testrood, 1st0: 147 , did discuss a Costa genus under this name.

Caliptici O. G. Costa, 1835,5 Fauna del Regno di Napoli, Famiglia de Coccinigliferi, o de' Gallinsetti. Emitteri Tapoli, p. 2.

Costa used this spelling for an italicized name, which was one "of three distinct genera" into which he dirided Coccus Linnaeus, sens. lat. We have found no eridence that it ever acquired status in the Coccoidea.

Callipalpus "Sign. 1875," Lindinger, 1937, Ent. Jahrb. $46: 181$.

In spite of diligent search through all the Signoret coccid papers known to us, we have failed to verify this spelling for a coceid generic name. I.indinger stated. "=Callipappus Guér."

"This paper shows no date or other eridence of actual time of issue, and coccid workers and bibliographers from Agassiz and Hagen through Neare. including Sherborn, and Horn and schenkling. are rague or arbitrars on the probable date of issue. Lindinger. $1943 \mathrm{c}: 24 \mathrm{~s}$, after haring earlier (1937: 1\$3) accepted an 1835 date for the work. reported that Guerin-Menerille. 184: 379. gare the date of publication for this Costa paper as 1*29. and. indeed. Guérin-Ménerille did state unequirocally that this was the publication date and that it considerabls preceded the Burmeister 1.s.5 Haudmuch. Because of the alprearance in 1828 of his paper (Costa 1 - 2 a i diriding the genus copeus. there is a degree of plausibilits in an assumption that Costa did proceed immediately thereafter to complete and publish his japer on the coccid fauna of the Naples region. However, the acceptance of a later date. usually 1835. has become so firmly fixed in coccid literature, and the Guérin-Ménerille allegation remains so comrletels without substantiation, in slite of much areful digging for eridence. that we hare arbitrarils accepted the rear 1 (n).5 as the date to be associated with the Costa "Fauna" names.

see foootnote on Calimmata Costa. 
Callipappus Guérin-Méneville, 1841, Rev. Zool. 4 : 129.

TYPE-SPECIES : Callipappus westwoodi Guérin-Méneville, 1841, by monotypy.

This genus has had a long association with the margarodine series of genera. See Morrison, 1928: 82, for a discussion of its relationships.

Callipapput "Guérin," Perroud and Montrousier, 1864, Soc. Linn. de Lyon, Ann. (n.s.) 11:247.

A lapsus for Callipappus Guérin-Méneville.

Callococcus Ferris, 1918, Canad. Ent. $50: 328$.

TYPE-SPECIES: Sphaerococcus pulchellus Maskell, 1897, by original designation and monotypy.

Its describer assigned this genus to the Asterolecaniidae. Morrison and Morrison, 1927 : 10, presented detailed descriptive information on three included species. Borchsenius, 1960d: 92, 128, discussed the genus and tentatively suggested its inclusion in his Polliniini.

Callypticus Signoret, 1869, Soc. Ent. de France Ann. (1868) (ser. 4) $8: 858$.

Presented in combination with a Costa species name as "Callypticus aterrimus," this spelling is an erident lapsus for Calypticus Costa. It has never attained acceptance in coccid literature.

Calycicoccus Brain, 1918, Bul. Ent. Res. 9 :11.

TYPE-SPECIES : Calycicoccus mervei Brain, 1918, by original designation and monotypy.

The describer set up a new subfamily, the Calycicoccinae, for this genus. Ferris, 1957b: 64, suggested that it should be assigned to the Eriococcidae along with certain other unusual genera. Hoy, 1963, New Zeal. Dept. Sci. and Indus. Res. Bul. 150: 7, placed it in the Eriococcidae.

Calycococcus “Brain 1918," Lindinger, 1937, Ent. Jahrb. 46 : 181.

An emendation of Calycicoccus Brain, not here accepted.

Calymmata O. G. Costa, 1828, Prospetto di una nuova divisione metodica del genere Coccus, Lin. Lam. ec. Napoli, Dalla Tipografia Trani, pp. 6-7.

TYPE-SPECIES : Coccus hesperidum Linnaesus, 1758, by subsequent indication of Cockerell, 1929b: 150, through his selection of this species as type for Calymmatus Costa, 1840, and Calypticus Costa, 1835, which are themselves Costa emendations of Calymmata, 1828.

This name is recognized as a synonym of Coccus Linnaeus in the currently accepted sense.

$208-496-66-3$ 
Calymmatus O. G. Costa, 1840, Atti del real Ist. d'Incoragg. alle sci. nat. di Napoli $6: 50$.

TYPE-SPECIES : Coccus hesperidum Linnaeus, 1758, by subsequent designation of Cockerell, $1929 \mathrm{~b}: 150$.

This usage occurs only in the explanation for the figures at the end of the paper as "Calymmatus hesperidum." Earlier in the body of the paper the reference is to Calypticus hesperidum. We assume that Calymmatus is a lapsus. The name is placed in synonymy under Coccus Linnaeus, 1758. Lindinger, 1937 : 181, credited this name to Costa, 1835 , but we cannot confirm this date.

Calymnatus "Costa" Signoret, 1868, Soc. Ent. de France Ann. (ser. 4) $8: 511 ; 1869$ (ser.4) $8: 856$.

TYPE-SPECIES : Coccus hesperidum Linnaeus, 1758, by subsequent indication of Cockerell, 1929b: 150, through his designation of this species as type for Calymmatus and Calypticus Costa.

Since Signoret (p. 511) discussed this name in relation to "Costa (1827)" it seems evident that it is a lapsus or an unannounced emendation of the original Calymmata Costa, 1828. Neave, 1939, Nomen. Zool. I: 554, listed it as "pro Calymma- Costa 1840," but the initial Signoret reference to "Costa 1827" seems to indicate clearly that Calymmata Costa, 1828, is involved. This and all other variations in the spelling of the Costa name are currently placed in synonymy under Coccus Linnaeus.

Calypticus O. G. Costa, 1835, Fauna del Regno di Napoli, Famiglia de' Coccinigliferi, o de' Gallinsetti. Emitteri Napoli, p. 8.

TYPE-SPECIES : Coccus hesperidum Linnaeus, 1758, by subsequent designation of Fernald, 1902: 178; also by Cockerell, 1929b : 150.

This generic name was proposed by Costa as a substitute for his Calymmata, 1828 , on the grounds that it was more exact. It is generally accepted to be a synonym of Coccus Linnaeus.

Calyptococcus Borchsenius, 1948, Akad. Nauk SSSR Dok. (n.s.) 61 : 956.

TYPE-SPECIES : Calyptococcus desertus Borehsenius, 1948, by original designation and monotypy.

The describer associated this genus with Coccura Šulc, Centrococcus Borchsenius and Mediococcus Kiritschenko in his Coccurini, Pseudococcidae.

Camptocecis Amyot, 1847, Soc. Ent. de France Ann. (ser. 2) 5: 503.

This name was proposed as a uninomial designation for a coccid species and so has no status as we understand the 1961 Nomenclature Code. According to Fernald, 1903b: 64, the species involved here is Kormes quercus (Linnaeus).

Canaspis MacGillivray, 1921, The Coccidae, pp. 308, 352.

TYPE-SPECIES : Chionaspis arundinariae Green, 1899, by original designation and monotypy.

The describer placed this genus in his Diaspidini. Lindinger, 1943b: 20s, apparently accepted it as valid. Ferris, 1937a: 3, accepted it as distinct from 
Chionaspis Signoret but later, 1952a: 6, placed it in synonymy with Greenaspis MacGillivray, 1921, first on the alleged grounds that the two genera have the same originally designated type-species, Chionaspis elongata Green, 1896, which is not true; later, on the basis that he had examined authentic material of the types of both genera and that he considered them to be congeneric, which probably is correct. As Ferris pointed out, Greenaspis has page priority. Balachowsky, 1954e: 171-172, assigned both genera to his Diaspidina, group II, chionaspiform, apparently without recognition of Ferris' previous conclusion regarding their identity. He also suggested that Greenaspis MacGillivray has a relationship to Pinnaspis Cockerell.

Canceraspis Hempel, 1934, Rev. d Ent. [Sao Paulo] 4: 141.

TYPE-SPECIES : Canceraspis brasiliensis Hempel, 1934, by original designation and monotypy.

Lepage, 1938: 432, synonymized this generic name with Limacoccus Bondar, 1929 : 59, and placed brasiliensis in Limacoccus. Hempel proposed the subfamily name Canceraspidinae for Canceraspis although Lepage, 1938: 432, placed this genus in the Phoenicococcidae.

Cannococcus Borchsenius, 1960, Ent. Obozr. 39: 932.

TYPE-SPECIES : Cannococcus cannicola Borchsenius, 1960, by original designation and monotypy.

Borchsenius placed this genus in the Pseudococcidae close to his Kiritshenkella and Neotrionymus.

Capulinia Signoret, 1875 , Soc. Ent. de France Ann. [Bul. Ent.] (ser.

5) 4: cexx; 1875, Soc. Ent. de France Ann. (ser. 5) 5:27.

TYPE-SPECIES : Capulinia sallei Signoret, 1875, by monotypy.

Its describer suggested that this genus associates with a group which he called the Acanthococcites. Cockerell, 1899m : 277, placed the genus in his Eriococcini. MacGillivray, 1921: 210, assigned it to Cylindrococcinae, as did Balachowsky, 1948b : 257. Ferris, 1955a : 224, 1957b, 66-67, after a study of the type-species, concluded that the genus cannot be placed comfortably in any accepted higher unit of coccid classification although he did suggest a possible relationship to the Australian genus Opisthoscelis Schrader. Hoy, 1963, New Zeal. Dept. Sci. and Indus. Res. Bul. 150 : 7, referred this genus to the Eriococeidae.

Cardiococcus Cockerell, 1903, Ann. and Mag. Nat. Hist. (ser. 7) 11: 155 .

TYPE-SPECIES : Cardiococcus umbonatus Cockerell, 1903, by original designation.

The describer suggested a relationship with Inglisia Maskell in the Coccidae (str.).

Carpochloroides Cockerell, 1899, Entomologist $32: 12$.

TYPE-SPECIES : Carpochloroides viridis Cockerell, 1899, by monotypy.

The describer suggested a relationship with Capulinia Signoret and Cylindrococcus Maskell for this genus. Ferris, 1957e: 84, considered that it belonged in the Eriococcidae and Hoy, 1963, New Zeal. Dept. Sci. and Indus. Res. Bul. 150 : 7, agreed. 
Carteria Signoret, 1874, Soc. Ent. de France Ann. (ser. 5) 4: 101.

TYPE-SPECIES : Coccus lacca Kerr, 1782, by original designation and monotypy.

This name, preoccupied in the Protozoa, 1866, and the Spongifera, 1867, was replaced by Tachardia $\mathbf{R}$. Blanchard, 1886. See Laccifer Oken and Kerria Targioni-Tozzetti for details on this complex situation.

Carulaspis MacGillirray, 1921, The Coccidae, pp. 305, 313.

TYPE-SPECIES : Diaspis juniperi Bouché, 1851, by original designation.

This genus has been recognized in recent years as a ralid segregate. Recent studies (Baccetti, 1960, Goidanich, 1960) have firmly established its validity in the Diaspidini. Balachowsky, 1954e: 165, mistakenly indicated the trpe-species for the genus as Coccus visci Schrank, 1781.

Casuarinaloma Froggatt, 1933, Limn. Soc. X.S. Wales, Proc. 58: 368.

TYPE-SPECIES : Sphaerococcus leaii Fuller, 1897, by monotypy.

The describer gave no indication as to the group assignment for this genus. Borchsenius, 1949: 44, implied an association with the Pseudococcidae in his listing of the genus as a member of the Australian fauna.

Casuarinoloma "Frogg. 1933," Lindinger, 1937, Ent. Jahrb. 46: 181. An emendation of Casuarinaloma Froggatt, not accepted here.

Cataenococcus Ferris, 1955, Microentomology 20 : 3.

TYPE-SPECIES : Dactylopius olivaceus Cockerell, 1896, by original designation.

Ferris established this genus for four species of North American mealybugs and indicated its relationship to the pseudococcid genus Farinococcus Morrison, described from South America.

Catenococcus Ferris, 1955 , Microentomology 20 : fig. 5.

A lapsus for Cataenococcus Ferris, that was repeated by McKenzie, 1960: 691.

Caulococcus Borchsenius, 1960, Akad. Nauk Tadzh. SSR Dok. 3: 47. TYPE-SPECIES: Phenacoccus angustatus Borchsenius, 1949, by original designation.

The describer discussed the relationship of this pseudococcid genus with Ferrisicoccus Ezzat \& McConnell and Heterococcopsis Borchsenius.

Cerococcus Ramakrishna Ayyar, 1919, Bombay Nat. Hist. Soc. Jour. $26: 627$.

A lapsus for Cerococcus Comstock.

Cecolepis Amyot, 1847, Soc. Ent. de France (ser. 2) 5:503.

This is a uninomial designation intended to replace a generic and specific name. Although listed in Neave, 1939, Nomen. Zool. I : 614, according to the 1961 Code it has no validity as a generic name. From the literature citations presented by Amyot we conclude that this probably relates to the species now known as Lepidosaphes ulmi (Linnaeus). 
Centrococcus Borchsenius, 1948, Akad. Nauk SSSR Dok. (n.s.) 61: 953.

TYPE-SPECIES : Eohinococcus echinatus Balachowsky, 1936, by substitution of Centrococcus for Echinococcus Balachowsky, and, 1949: 307, confirmed by definite designation as type-species.

The author presented this name as a replacement for Echinococcus Balachowsky, 1936, preoccupied, and placed it and three other mealybug genera, Coccura Šulc, Mediococcus Kiritshenko, and Calyptococcus Borchsenius in a new tribe, the Coccurini. Lindinger, 1943b : 218, proposed Coccidohystrix as a replacement for Echinococcus, and Centrococcus must fall into synonymy with Coccidohystrix.

Cephalaspis MacGillivray, 1921, The Coccidae, pp. 274, 286.

TYPE-SPECIES: Mytilaspis cocculi Green, 1896, by original designation and monotypy.

According to Neave, 1939, Nomen. Zool. I : 625, this generic name was preoccupied through use by Agassiz in 1835 in Pisces. Takahashi, 1939b: 265, and Balachowsky, 1954e : 28, placed this name as a synonym of Lepidosaphes Shimer.

Cercococcus Scott, 1907, Linn. Soc. London, Trans. Zool. (ser. 2) 9 : 455 .

TYPE-SPECIES : Cercococcus eremobius Scott, 1907, by monotypy.

The describer associated this genus with Asterolecanium Targioni-Tozzetti in the Dactylopiinae. Subsequent consideration has generally assigned the name as a synonym of Cerococcus Comstock, 1882. Borchsenius, 1960d : 105, accepted the genus as valid with two definite, and nine suggested, Palearctic inclusions.

Ceriococcus Mahdihassan, 1946, Current Sci. [India] 15: 197.

A lapsus for Coricoccus Mahdihassan.

Cerococcus Comstock, 1882, U.S. Dept. Agr., Comnr. Agr. Rpt., 1881$1882: 213$.

TYPE-SPECIES : Cerococcus quercus Comstock, 1882, by monotypy.

This genus is currently well established as a member of the Asterolecaniidae.

Ceronema Maskell, 1895, New Zeal. Inst. Trans. and Proc. (1894) $27: 55$.

TYPE-SPECIES : Ceronema banksiae Maskell, 1895, by monotypy.

The type-species of this genus was redescribed in detail by Morrison and Morrison, 1922: 60. The Fernald Catalogue, 1903b: 127, associated the genus rather closely with Pulvinaria Targioni-Tozzetti, but there seems to have been no recent discussion of its associations within the Coccidae (str.).

Ceronesera Watt and Mann, 1903, Pests and Blights of the Tea Plant, Ed. 2, p. 310.

From the usage, this appears to be a lapsus for Ceronema Maskell.

Ceronina Kuwana, 1917, A Check List of the Japanese Coccidae, p. 8. A lapsus for Ceronema Maskell. 
Ceroplasses Sankaran, 1954, Jour. Sci. Res. Benares Hindu Univ. $5: 100$.

A lapsus for Ceroplastes Gray.

Ceroplastes Gray, 1828, Spicilegia Zoologica, pt. I, p. T.

TYPE-SPECIES : Coccus (Ceroplastes) chilensis Gray, 1827, by subsequent designation of Fernald, 1903b: 147 (the first we have found).

This is a well known, widely distributed genus of the Coccidae (str.) which probably will be divided into sereral segregates beyond the two already proposed by Cockerell, 1910a: 76, when the species currently assigned to it have been giren critical study.

Ceroplastidia Cockerell, 1910, Canad. Ent. $42: 76$.

TYPE-SPECIES: Ceroplastes bruneri T. D. A. and W. P. Cockerell, 1902, by original designation.

This was established as a subgenus on the basis of growth habit, for species that crowd closely together on the host twig, produce solid masses of covering wax, and have the bodies vertically distorted. Morrison, 1919: 76, commented on this genus, noting its similarity to the genus Gascardia Targioni-Tozzetti, 1893, and its doubtful distinction from Ceroplastes Gray, sens. lat.

Ceroplastina Cockerell, 1910, Canad. Ent. $42: 76$.

TYPE-SPECIES: Ceroplastes lahillei Cockerell, 1910, by original designation.

This was established as a subgenus by its describer on the basis of the unusual development of the waxy covering of the body of the adult female.

Ceroplastodes Cockerell, 1893, Entomologist $26: 350$.

TYPE-SPECIES : Fairmairia (subg. Ceroplastodes) nivea Cockerell, 1893, by original designation and monotypy.

Cockerell, 1902n : 194, concluded that nivea must be a synonym of Lecanopsis Augesii "Lichtenstein" Signoret, 1886a: xxxix, on the basis of his examination of topotype material sent to him by Dugès, who had forwarded the material of dugesii to Lichtenstein. Subsequently (Fernald, 1903b : 164; Steinweden, 1929: 232 ; Lindinger, $1937: 181$ ) it has been customary to cite dugesii as the type of the genus Ceroplastodes. It seems probable that this synonym, which has been accepted, is valid but it has not been based on a direct comparison of the types of the two species. The genus has been assigned to the "glassy" section of the Coccidae (str.), but seems not to have received critical restudy in recent years. There is doubt if the Indo-Malayan and Australian species assigned here actually associate generically with the North American inclusions.

Ceroplastus "Grmy." Trestwood, 18t0, In Introduction to the Modern Classification of Insects $2: 449$.

In the Westwood context this appears to be a misspelling of Ceroplastes Gray. The name was used in Coleoptera in 1883, according to Neave, 1939, Nomen. Zool. I : 648 . 
Ceroputo Sulc, 1898, K. Böhmisch. Gesell. der Wiss. Sitzber. (1897) No. $66: 1$.

TYPE-SPECIES : Ceroputo pilosellae Šulc, 1898, by monotypy.

This genus is accepted as closely related to Puto Signoret, 1876. Ferris, 1918d: 34, 61, 1950b : 190, actually placed Ceroputo as a synonym of Puto. Recent European workers including Lindinger, 1937: 181; Borchsenius, 1948b: 31, 1949: 285, 289-290; and Reyne, 1954a : 323, regard the genus as distinct. Balachowsky, 1948b : 253, assigned it to the Pseudococeini, but there is evidence that this genus and Puto deserve a sharper group separation from other known pseudococcids.

Cerrococcus Kiritschenko, 1936, Inst. Zashch. Rast. Plant Protect. $9: 70$.

A lapsus for Cerococcus Comstock.

Chaetaonidia Balachowsky, 1948, Actualités Sci. et Indus., Ent. Appl. $1054: 269$, nomen nudum; $1951,1127: 615$.

TYPE-SPECIES: Aonidia tlaiae Balachowsky, 1927, by original designation and monotypy.

This genus was proposed in 1948 without description. Balachowsky, 1951: 615 , indicated that the name was a synonym of Cryptoparlatoreopsis Borchsenius, 1947.

Chaetococcus Maskell, 1898, New Zeal. Inst. 'Trans. and Proc. (1897) $30: 249$.

TYPE-SPECIES : Sphaerococcus bambusae Maskell, 1893, by subsequent designation of Fernald, 1903b: 120 (the first we have located).

This belongs with Antonina Signoret and some other genera in a group of much modified mealybugs. Betrem, 1937 : 21, 97, and Lindinger, 1937: 181, placed the name as a synonym of Antonina. Goux, 1935a : 96, and Borchsenius, 1949: 314, recognized the genus and the latter assigned species to it. It appears to be validly distinct from Antonina.

Chavesia Balachowsky, 1957, Rev. de Path. Veg. et d'Ent. Agr. de France $36: 158-159$.

TYPE-SPECTES: Chavesia caldasiae Balachowsky, 1957, by original designation and monotypy.

The describer assigned this coccid genus to the group "Kerminae-Eriococcini," related to Eumyrmococcus Silvestri. Hoy, 1963, New Zeal. Dept. Sci. and Indus. Res. Bul. 150: 8, examined specimens of the type-species and found no morphological grounds for association with the Eriococcidae.

Chelinococcus Signoret, 1869, Soc. Ent. de France Ann. (ser. 4) 9 : 104.

A lapsus for Chelonicoccus A. Costa. 
Chelonicoccus A. Costa, 1866, Accad. delle Sci. Fis. e Mat. Napoli, Atti 3 (7) : 10; Silvestri, 1920, in Leonardi, Monografia delle Cocciniglie Italiane, p. 500.

TXPE-SPECIES : Chelonicoccus luteus Costa, 1866, by monotypy.

Originally described as a "singular" Italian coccid, Silvestri reported that examination of the type specimen showed it to be a part of a lepidopterous chrysalid, probably of a lycaenid.

Chemnaspidiotus MacGillivray, 1921, The Coccidae, p. 391.

TYPE-SPECIES: Cryptophyllaspis liquidambaris Kotinsky, 1903, by original designation and monotypy.

Lindinger, 1937: 181, placed this name as a synonym of Aspidiotus Bouché. Ferris, 1938a: SII-223, considered that the type-species belonged in the genus Diaspidiotus Berlese and Leonardi. Recent usage has aroided the use of the name.

Chentraspis Leonardi, 1897, Riv. di Patol. Veg. (Nov. 1896-Feb. 1897 ) 5:284, 286; 1897, 6: 111 (again presented as a new genus).

TYPE-SPECIES : Aspidiotus unilobis Maskell, 1895, by subsequent restriction by Cockerell, 1899a : 395, where he included only the species unitobis under this generic heading, and by subsequent designation by Fernald, 1903b: 251.

Morrison and Morrison, 1922: 93, were in error when they alleged that only one species was included in the genus at the time it was established. Actually another species, Aspidiotus extensus Maskell, 1895, was also assigned here. Lindinger, 1937: 181, designated extensus as type-species, apparently on a "first species" selection basis, and ignored the prior designations cited abore. In the same lists he indicated that Chentraspis, as discussed by Leonardi in 1898 [apparently 1897b: 111], represented a different concept than the original presentation and proposed a new genus, Neglectaspis, for this, with unilobis Maskell as type-species. Lindinger, 1937: 190, also considered Neoleonardia MacGillivray to be a synonym of Chentraspis as he restricted it, but this can be true only if his type fixation is accepted. Ferris, 1937e: 528, rejected Lindinger's 1937 type-species selection because of the action presented in the Fernald Catalogne. Lindinger, 1943b: 217, again insisted that extensus was the type-species of the genus, apparently this time basing his contention on the fact that the combination Chentraspis extensus occurs one page before Chentraspis unilobis in Cockerell's, 1897i: 26-27, list of Australian aspidiotine species. We do not agree with this, and consider that the earlier type assignment of unilobis has validity to fix the nature of the genus, which, on this basis, seems definitely to be aspidiotine in character.

Chermes Geoffroy, 1762, Histoire Abrégée des Insectes qui se trouvent aux environs de Paris, v. 1:498-504.

In this spelling and authorship this genus appears to have no current status in the Coccoidea although several early species of coccids were described under the name. The name was proposed first by Linnaeus in 1758 and seems definitely not to be applicable to any coccid. In Amyot and Serville, 1843, Hist. Nat. Ins. Hem., 1). 630, this name was used as an alternate for the coccid Kermes Boitard, 1828 , lut wholly without nomenclatorial justification according to presently accepted rules. 
Chianaspis Froggatt, 1908, Dept. Agr. Victoria, Jour. 6 (8) : 489.

A lapsus for Chionaspis Signoret.

Chinaspis Gómez-Menor, 1954, Eos 30:122.

TYPE-SPECIES: Chinaspis vellae Gómez-Menor, 1954, by original designation and monotypy.

The describer assigned this genus as close to Lindingaspis MacGillivray, one of the aspidiotine series of genera.

Chiomaspis Borchsenius, 1938, Akad. Nauk SSSR Izv. 29: 139.

A lapsus for Chionaspis Signoret.

Chionapsis Mouillefert, 1903, in Lindinger, 1954, Beitr. z. Ent. 4 $(5 / 6): 620$.

A lapsus for Chionaspis Signoret. This spelling appeared also in Lameere, 1936, Précis de Zoologie 4 : 416.

Chionaspis Signoret, 1869, Soc. Ent. de France Ann. (ser. 4) 8: 814, 854, 871-872, 874; 1869, (ser. 4) 9:442 (first description: $C$. salicis offered as an "example").

TYPE-SPECIES: Coccus salicis Linnaeus, 1758, by subsequent designation of Cooley, 1899: 3, 9-10.

Numerous diaspid species of uncertain relationships have been described under this generic name, but in recent sears many have been reassigned into new, restricted generic units, some of which appear to be zoologically valid. Depending on the individual viewpoint, there are now few to numerous synonyms placed under Chionaspis Signoret. The trend appears to be in the direction of restricting the use of Chionaspis to Holarctic species with acceptance of other generic units for species originally placed in this genus from other areas. Balachowsky, 1954 : 163 , placed the genus in his Diaspidina chionaspiform.

Chironomus Fabricius, 180气, Systema Antliatorum, p. 46.

This generic name entered into coccid literature because of the description of Chironomus dubius Fabricius, 1805, now accepted as a male margarodid. C. plumosus Fabricius, a dipterous insect, appears to have been established as the type of the genus by dipterists. An hemipterous association was indicated for the name by Schulze, 1927, Nomenclator animalium generum et subgenerum 2: 660, and Sherborn, 1932, Index Animalium 2 (29): 47. Neare, 1939, Nomen. Zool. I : 699, recognized it only as a dipterous genus name.

Chlamidolecanium Lindinger, 1935, Ent. Jahrb. 44: 142; 1936, 45 : 155 .

A lapsus for Chlamydolecanium Goux.

Chlamydolecanium Goux, 1933, Soc. Ent. de France Bul. 38:119-120.

TXPE-SPECIES : Chlamydolecanium conchioides Goux, 1933, by original designation and monotypy.

Lindinger, $1937: 182$, placed this name as a synonym of Parafairmea [Lindinger spelling], but Borchsenius, 1957: 138, accepted the genus as valid, and assigned it to his Filippiinae in the Coccidae (str.). 
Chlidaspis Borchsenius, 1949, Akad. Nauk SSSR Dok. (n. s.) 64: $736-737$.

TYPE-SPECIES : Phenacaspis prunorum Borchsenius, 1939, by original designation and monotypy.

The describer placed this genus close to Phenacaspis Cooley and Cockerell, in the Diaspidini. Balachorsky, 1954e: 369, srnonymized the name with Tecaspis Hall, 1946. Borchsenius and Williams, 1963, Brit. Mus. (Nat. Hist.) Ent. Bul. 13: $357-358$, 360, regarded the genus as ralid and belonging to a group of genera comprising Tecaspis Hall, Voraspis Hall, and Rolaspis Hall. They stated that Toraspis adlei Balachowsky and Kaussari, 1955, is identical with the type-species.

Chloeoon Anderson, 1788, Letters to Sir Joseph Banks, Baronet, President of the Royal Society, on the subject of cochineal insects, discovered at Madras [I-XIV] : 6, 25.

TYPE-SPECIES : Kermes choromandelensis Anderson, 1788, [p. 25], by monotypy.

According to a microfilm copy of Anderson's letters to Banks, 1788, obtained from the New York Public Library, this name was published by Anderson for a definitely stated genus, placed between Coccus Linnaeus and Kermes Boitard. Although a species name was not directly associated with the first mention (p. 6) of the generic name, the author (p. 25) later listed it, along with several other new coccid names, as "The Chloeoon or Kermes Choromandelensis." We consider that the generic name was validly established by Anderson's actions, and that the species name he proposed is to be accepted as its type-species. A plate showing illustrations of this and other coccids accompanied the descriptive information in the "Letters" and this insect was displajed in position on its grass host and also in crude detail. One of the pertinent illustrations, called the caterpillar stage of the coccid, seems clearly to represent the larral stage of some predatory insect, perhaps of a chrysopid. A second illustration, called the fly, supposed to be a male viewed with the microscope, is also highly suspect, as the figure is not clearly assignable to any insect group and its description reports the presence of four procumbent wings. Signoret, 1877: 612, considered the "ffy" a hymenopterous insect. The remaining illustrations (figs. 1, 3-4) seem clearly to represent a coccid species and the habitus illustration strongly suggests the coccid currently going under the name Antonina graminis (Maskell), 1897, a species which was described from India as Antonina indica Green, 1908. We do not, however, present this indication as a firm assignment of $A$. graminis into synonymy under the Anderson names and consider that the species should continue to go under the name in current use. There seems to be no prospect of reaching a more critical decision on the identity of Anderson's species.

Chloropulvinaria Borchsenius, 1952, Akad. Nauk SSSR Zool. Inst. Trudy $12: 299-300$.

TYPE-SPECIES : Coccus flocciferus Westwood, 1870, br original designation.

Borchsenius, 1957: 203, placed this in his Pulvinarini, Coccinae, Coccidae (str.). 
Chnaurococcus Ferris, 19ð0, Atlas of the Scale Insects of North America (ser.) 5 [v. 5]: 40.

TYPE-SPECIES : Ripersia villosa Ehrhorn, 1899, by original designation.

The describer suggested a possible relationship for this genus with Cryptoripersia Cockerell in the Pseudococcidae.

Choetococcus Goux, 1936, Soc. Ent. de France Bul. 41 : 10 .

A lapsus for Chaetococcus Maskell.

Chorizaspidiotus MacGillivray, 1921, The Coccidae, p. 391.

TYPE-SPECIES: Aspidiotus (Targionia) gutierreziae Cockerell and Parrott, 1899, by original designation. [A synonym of Aspidiotus dearnessi Cockerell, 1898, according to Ferris, 1937a : 33.]

Ferris, 1937a : 33, 1938a: SII-213, 1943a: 99, placed this name as a synonym of Rhizaspidiotus MacGillivray. Balachowsky, 1951: 650, and 1958b : 288, agreed with the Ferris conclusions.

Chorizococcus McKenzie, 1960, Hilgardia 29 : 692.

TYPE-SPECIES : Chorizococcus wilkeyi McKenzie, 1960, by original designation.

The describer associated this genus closely with spilococcus Ferris in the Pseudococcidae and also suggested relationships with Atrococcus Goux and Allotrionymus Takahashi.

Chortinaspis Ferris, 1938, Microentomology 3: 46, nomen nudum; 1938, Atlas of the Scale Insects of North America (ser. 2) [v. 2]: SII-194.

TYPE-SPECIES : Aspidiotus chortinus Ferris, 1921, by original designation.

The describer placed this genus in the Aspidiotini. Balachowsky, 1948b: 382 , accepted the genus as valid and assigned it to his Aspidiotina.

Chrysomphalus Ashmead, 1880, Amer. Ent. 3: 267.

TYPE-SPECIES : (Chrysomphalus ficus Ashmead, 1880)=Coccus aonidum Linnaeus, 1758 , by monotypy.

The date and citation presented above are generally accepted for the establishment of this aspidiotine genus. However, Ashmead, 1879, Florida Agriculturist, v. 2, published an account of the insect, and it is possible that he included sufficient descriptive material to fix the genus and species from that date. We have not seen this publication. Coccus aonidum Linnaeus, 1758 , has been widely recognized as type-species, but Ferris, 1937c: 50, 53-54, first accepted, then, 1937d: 105, rejected the concept and retained ficus as type-species. Williams (1960, in lit.) examined type specimens of aonidum in the collection of the Linnaean Society of London and decided that ficus Ashmead of authors was identical with it. We have not succeeded in locating type material of ficus.

Chrysonphalus Monastero, 1955, Palermo Univ. Ist. Ent. Agr. e Osserv. Fitopat. Bol. 1:89.

A lapsus for Chrysomphatus Ashmead. 
Cintococcus Goux, 1940, Soc. d'Hist. Nat. l'Afrique du Nord, Bul. 31: 61-62.

TYPE-SPECIES : Ripersia cinti Balachowskr, 1933, by original designation and monotspy.

This was described originally as a subgenus of Ripersia Signoret but at a time when there was little critical understanding of the nature of Ripersia as a pseudococcid genus.

Cionops Leach. 1815, in Brewster's Edinb. Encrc. 9: 126 (according to Agassiz, 1845, List of Zoological Names, and Femald, 1903b: 33). Sherborn, 1925, Index Animal., sec. 2, pt. TI : 1318, and Neare, 1939, Nomen. Zool. I : 740, state, "not located on search."

Te hare not succeeded in locating a cops of the $181 \mathrm{~J}$ edition of the Edinburgh Encyclopedia, so can contribute no critical comment on this name and its citation. The name seems to be universally accepted as a synonym of Orthezia Bose d'Antic, 1784, but we have found no mention earlier than Westwood, 1840: 450, where it stands as a synonym of Orthezia, and therefore hare no assurance that it actually has any status. It does not, for example, appear in Signoret's extensive study of the coccids, which started with a reriew of the work of earlier coccid authors. Perhaps it should be charged against Westmood, 1840, rather than Leach, 1815.

Circaputo McKenzie, 1962, Hilgardia $32: 643$.

TYPE-SPECIES: Circaputo hirsutus McKenzie, 1962, by original designation and monotypy.

The describer placed this pseudococcid genus as related to Cataenococcus Ferris, Paraputo Laing, and Criniticoccus Williams.

Circulaspis MacGillirray, 1921, The Coccidae, p. 393.

TYPE-SPECIES: Odonaspis canaliculata Green, 1900, by original designation and monotypy.

Ferris, 1937a: 33 , considered this a valid genus zoologically, but later, 1938a: SII-156, 161, questioned if it represented a sound segregate. Balachorsks, $1948 b$ : 264, $1949: 109$, accepted it as ralid in the Odonaspidini.

Cissococcus Cockerell, 1902, Amn, and Mag. Nat. Hist. (ser. i) $9: 23$.

TYPE-SPECIES: Cissococcus fulleri Cockerell, 1902, by original designation and monotypy.

The describer assigned this genus to the Eriococcini. Brain, 1915: 109, established the Cissococcinae for it. Ferris, 1920a: 65, assigned it to the Coccidae (str.), reporting affinities with Ceroplastes Gray. Steinweden, 1929: 233, discussed it but added nothing to the Ferris opinion.

Cisticoccus A. Costa, 1877, Degl' Insetti che attaccano l' Albero ed il frutto dell' Olivo, Ed. 2, rev. and enl., Napoli, R. Ist. d'Incoraggiamento, pp. 125, 127.

Costa proposed this name as a substitute for Pollinin Targioni-Tozzetti, 186s,

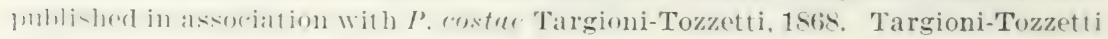


presented the latter names as a new genus and species combination to replace "Coccus Pollini" A. Costa, 1857: 77 (not O. Costa, 1828, as cited in Fernald, 1903b : 60). Costa (1877) properly pointed out the impropriety of substituting a complete new name for his "Coccus Pollini", but erred, according to the standards accepted to-day, in substituting his own new generic name for the one proposed by Targioni-Tozzetti. Since Cisticoccus is based on the same insect as Pollinia, the name is a synonym of the latter. Lindinger, 1937: 182, listed the spelling above, and the alternate spelling "Cystococcus Costa 1877". We have had no success in locating this spelling in Costa's paper of that date, or elsewhere.

\section{Clavaspis MacGillivray, 1921, The Coccidae, p. 391.}

TYPE-SPECIES : (Aspidiotus subsimilis var. anonae Houser, 1918)=Aspidiotus herculeanus Cockerell and Hadden, 1909, by original designation.

Ferris, 1937e: 50, 53, accepted this genus as valid and indicated the common identity of the two species, subsimilis anonae and herculeanus, included by MacGillivray. Later, 1938a: SII-202-214, he reviewed the North American species assigned to the genus.

Balachowsky, 1950b: 490 and 1956: 90-92, accepted the genus for various Old World species and placed it in his Aspidiotina, close to Diaspitiotus "Leonardi."

Clavataspis Ferris, 1955, Microentomology $20: 24$.

This name seems to have been presented in error in citing the type-species of Scytalaspis Ferris.

Clavicoccus Ferris, 1948, in Zimmerman, 1948, Insects of Hawaii 5 : $148,168$.

TYPE-SPECIES : Clavicoccus tribulus Ferris, 1948, by original designation.

This is an unusual genus belonging to the Pseudococcidae.

Clypeococcus Newstead, 1920, Bul. Ent. Res. 10:175.

TYPE-SPECIES : Icerya (Crypticerya) hempeli Cockerell, 1899, by original designation and monotypy.

This genus was established because of Newstead's belief that he could recog. nize a clypeus on the type specimens. Morrison, 1928: 105, discussed the name as a synonym of Mimosicerya Cockerell.

Cnetochiton Balachowsky, 1932, Encyc. Ent. (ser. A) 15: 36, 38.

A lapsus for Ctenochiton Maskell.

Cocccionella Lindinger, 1958, Beitr. z. Ent. 8: 371.

A lapsus for Coccionella Hahnemanns.

Coccicaccia Amyot, 1847, Soc. Ent. de France Ann. (ser. 2) 5:496.

A uninomial designation for a coccid of uncertain status but which we suspect might be Coccus cassiae Chavannes, 1848 . We believe this has no validity as a generic name but it is included in Neave, 1939, Nomen. Zool. I : 778. 
Coccidella Hambleton, 1946, Biol. Soc. Wash. Proc. $59: 17$.

TYPE-SPECIES: Morrisonella poensis Hambleton, 1946, by substitution of Coccidella for Morrisonella Hambleton.

The describer proposed this new name for Morrisonella Hambleton, 1946, preoccupied by Morrisonella Bartsch, 1945, in the Mollusca. Ferris, 1953a: 426, considered Coccidella a synonym of Rhizoecus Künckel d'Herculais.

Coccidohystrix Lindinger, 1943, Ztschr. der Trien. Ent. Gesell. 28 : 218.

TYPE-SPECIES : Echinococcus echinatus Balachowsks, 1936, by original designation and monotypy.

Lindinger, 1943b : 219, proposed this generic name as a substitute for Echinococcus Balachowsky, 1936c: 157, preoccupied in Vermes. For further discussion of associated complications, see under Centrococcus Borchsenius.

Coccilacca Anyot, 18tī, Soc. Ent. de France Ann. (ser. 2) $5: 495$.

This is a uninomial designation with no validity as a generic name, although it is listed in Neave, 1939, Nomen. Zool. I : 778. We presume that it is intended to stand for Coccus lacca Kerr.

Coccinella Gmelin, 1766, Onomatologia Hist. Nat. Completa 3 : column 22.

This was used by the author as a pseudogeneric name to designate the cochineal insect. In the same volume it was also used (col. 27) for the genus Coccinella in the Coleoptera. We beliere that the coccid usage has no nomenclatorial status.

Coccionella Gmelin, 1766, Onomatologia Hist. Nat. Completa 3: column 22 ; Hahnemanns, 1793, Apothekerlexikon 1 (1) :193.

Gmelin used this name as a uninomial to designate the cochineal coccid. We believe that this usage does not gire the name generic standing in the Coccoidea. Hahnemanns used the name as an apparent generic unit in association with a species Coccionella polonicus [Linnaeus, 1758], writing the name in italies. He also used the name as a minomial in the same alphabetical sequence to refer to what we presume is the true Mexican cochineal coccid, which he further referred to, in the same sequence, under the name "Coccus Cacti L." which was written in Roman type. Neare, 1939, Nomen. Zool. I : 778, noted only the 1860 use of this name by Voet in the Coleoptera. Lindinger, 1954: 614, who discovered the 1793 . apparently binomial, use of this name for a coccid, presented the case for acceptance. After examining the original Hahnemanns presentation, we reluctantly conclude that it is possible to interpret the latter's treatment (names presented in italics) as a binomial scientific name, eren though he presented all other coceit binomials that were noted in his Lexicon in undifferentiated Roman type-e.g. "Coccus Cacti L." Howerer, we cannot agree with Lindinger's use of the name as a total replacement for Margurodes Guilding. 1N29, sensus latus. There hats been sufficient work in recent rears, notably by Silvestri, 1936-1939a, to demonstrate clearly that Wargarodes sensus latus is a complex of morphologically diverse species which can legitimatels go into sereral distinct genera. Therefore Coccionella, if accepted, can replace only Porphyrophora Brandt, 1833. 
Coccomytilus Leonardi, 1898, Riv. di Patol. Teg. (1897) $6: \pm 5$ (20气) $46(206)$.

TYPE-SPECIES: Mytilaspis concexa Maskell, 1894, b5 subsequent designation

in Fernald Catalogue, 1903b : 304.

The trpe of this genus was redescribed br Morrison and Morrison, 1922: 100. Ferris, 1941a : 12, accepted it as a ralid genus. Silrestri, 1939: 812, differentiated it from Iytilococcus Amerling [Lepidosaphes of authors]. It also was accepted as ralid br Hall, 1946a : 508, and Balachowsky, 1954e: 23, 117, who placed it in his Lepidosaphedina.

Cocconidia Amyot, 18tī, Soc. Ent. de France Ann. (ser. 2) כ̌ $49 t$.

This is a uninomial designation beliered to stand for the mealybug currently known as Pseudococcus adonidum (Linnaeus), 175s. Although entered in Neare, 1939, Nomen. Zool. I: 779, it appears to have no standing as a coccid generic name.

Coccopoa Amyot, 18tī, Soc. Ent. de France Ann. (ser. 2) ǒ : 494.

The author presented this uninomial designation as a substitute for Coccus phalaridis Linnaeus, 1761 . This species does not seem to have been placed critically in modern coccid classification. It is presented in Neare, 1939, Nomen. Zool. I : 779, although without standing as a coccid generic name.

Coccoptelia Amyot, 1847, Soc. Ent. de France Ann. (ser. 2) ว : 495.

This is a uninomial designation offered to replace a generic and specific name for the insect inrolred, which in this instance seems to be the cocid currently called Gossyparia spuria (Modeer), 177s. This Amsot name appears to hare no ralidity as representing a generic unit but is included in Neare, 1939, Nomen. Zool. I : 779.

Coccum Ledermüllers, 1760, Mikroskopischer Gemüths-und AugenErgötzung, pp. 64-65, 73.

The author presented this name as a personalls preferred alternate spelling of the Greek-derired Coccus. While he associated this with polonicum and other specific names. his treatment does not appear to be strictly binomial throughout his discussion. so the name does not seem to be arailable besond recognition of its identity with the widely accepted Coccus Linnaeus.

Coccura Sule, 1908, Klubu Prirod., Prostejore, Vest. (1907), p. 64.

TYPE-SPECIES: Coccus comari Künow, 1880, by original designation and monotspy.

There has been confusion in the discussions of the status of this genus. Lindinger. 1937: 182, indicated its identits with Tetrura Lichtenstein, 1882, beliering that its trpe-species was identical with T. rubi Lichtenstein, 1882. Subsequent workers, especially Borchsenius, 1948a : 953, considered that the trpe-species of these two genera were distinct and that Coccura was ralid. Borchsenius placed it in a recognizable group of the Pseudococcidae, which he called the Coccurini, and included here also the genera Hediococcus Kiritshenko, Centrococcus Borchsenius, and Calyptococcus Borchsenius. Takahashi, 195s: 3, accepted it as a valid genus for Japan. 


\section{Coccus Linnaeus, 1758, Systema Nat. (Ed. 10) 1: 45ॅ-457.}

TYPE-SPECIES : Coccus hesperidum Linnaeus, 1758, by general acceptance.

Neare, 1939, Nomen. Zool. I : 781, also cites 1767, Ed. $12: 7$, 39. The significance of the later citation is not obvious at this writing. As the first established and oldest valid coccid genus, Coccus has had a most involved history. At the time of its establishment, and through the years since, numerous coccoid species representing a wide variety of forms hare been assigned to it, and a number of entomologists hare attempted to fix the correct type-species for the genus. Fernald, 1902a : 232, $1906: 125$, gare critical consideration to the problem in relation to her 1903b Catalogue of the Coccidae, and decided that Sulzer, 1761, in his discussion of the genus, with a reference to $C$. hesperidum Linnaeus by name, accompanied br an illustrated description of this insect, had set the trpe by restriction to this single species.

Historically, and in terms of the original Greek source of the name Coccus, its trpe probably ought to stand as one of the originally included oak-infesting species currently placed in the genus Kermes Boitard and, indeed, Westwood, 1840:447, presented this conclusion when he stated, "The type of this family (and for which, of course, the generic name Coccus must unquestionably be retained, . . . . ) is the Coccus ilicis Linn." Cockerell, 1929b : 150, arrived at the some conclusion, apparentls without recognition of Westwood's prior decision on the matter. Cockerell made sereral attempts at trpe fixation. In 1893dd: 1044, he discussed Coccus "as typified by $C$. cacti", with the associated discussion clearly indicating that he was citing Coccus cacti of authors, not Linnaeus [=Dactylopius coccus Costa of current usage]. This association was repeated by him in his $1896 \mathrm{~b}$ Check List : 323 . In $1899 \mathrm{j}: 260$, after debate, he concluded that Coccus phalaridis Linnaeus, 1758, must be chosen as trpe-species of the genus because it was the only original Linnaean inclusion remaining in Coccus after dirision of the genus by Geoffror, 1762 (a non-binomial work). Other attempts at type fixation include Latreille, 1810: 266, 434, who gave Coccus persicae Fabricius-a non-Linnaean and ineligible species-as the typical species; Kirkaldy, 1906a: 253, who stated that the type was mexicanus Lamarck, 1801 : 298, which also was not an inclusion br Linnaeus in his 1758 Coccus. MacGillirray 1921: 102, associated the name Coccus with the true Mexican cochineal, using the name cacti Linnaeus for it.

A majority of the coccid students publishing since the appearance of the Fernald Catalogue, 1903b, have accepted $C$. hesperidum Linnaeus, 1758, as the trpespecies of the genus. Coccid workers who have recently mentioned the genus with hesperidum accepted as the type-species include: Balachowsky, 1948b : 255256. who placed it with related genera in his Lecaniini ; Borchsenius. 1937 : 75, 86, 19.57 : 292. who placed it in his Coccini ; DeLotto, 1957: 295, 1959: 151: Ferris, in Zimmerman, 1948: 301; Gómez-Menor, 1937: 254. 295. and 1948 : 82 ; Laing. 1944: 93, who considered that Latreille, 1802: 267, fixed the type of Coccus by citing Coceus hesperidum Linnaeus as an "Example;" Lindinger, 1937: 182, who chose hesperidum as type on a "first species listed" basis; Mamet, 1954: 4S ; Schmutterer. 19.52: 5.52: and Silrestri, 1939: 716, who placed the genus in the Coccini. Beyond usige by coccid specialists, there is a considerable rolume of reference to "Coceus hesperidum L." in non-taxonomic literature that has appeared since the publication of the Fernald Catalogue. None of the attempts at trpe fixation reported above appear to us to comply with a rigid application of the requirements of the 1961 International Code. However, the use of hesperidum Linnaeus, 1758. as understood by current coccid workers, for the type-species of Coccus has become so nearly unirersal that we helieve strongly that it should be accepted without further questioning, and that the accentance should date from sulzer. 1761, as proposed by Fernald. 
Cockerellaspis MacGillivray, 1921, The Coccidae, p. 306.

TYPE-SPECIES : Aulacaspis montana Cockerell, 1896, by original designation and monotypy.

Ferris, 1936a: 21, 24, regarded this name as a synonym of Diaspis Costa, but later, 1937: SI-21, 49, 52, placed it as a synonym of Epidiaspis Cockerell. No later opinion on the name is available.

Cockerellella MacGillivray, 1921, The Coccidae, p. 71.

TYPE-SPECIES : Monophlebulus townsendi Cockerell, 1905, by monotypy.

Morrison, 1928: 63, placed this as a synonym of Drosicha Walker.

Cocus Breyer, 1862, Soc. Ent. de Belg. Ann. 6: 98.

A lapsus for Coccus Linnaeus.

Coelostoma Maskell, 1880, New Zeal. Inst. Trans. and Proc. (1879) $12: 294$.

TYPE-SPECIES : Coelostoma zealandica ذIaskell, 1880, by monotypy.

This name was preoccupied by Coelostoma Brullé, 1835, in the Coleoptera, and was replaced by Coelostomidia Cockerell.

Coelostomidia Cockerell, 1900, Nature [London] 61:367.

TYPE-SPECIES : Coelostoma zealandica Maskell, 1880, by substitution of Coelostomidia for Coelostoma Maskell.

This name was proposed by Cockerell to replace preoccupied Coelostoma Maskell. See Morrison, 1928: 112, for discussions of the structures and classification of the genus.

Coleococcus Borchsenius, 1962, Akad. Nauk SSSR Zool. Inst. Trudy $30: 240$.

TYPE-SPECIES : Coleococcus scotophilus Borchsenius, 1962, by original designation and monotypy.

Its describer placed this genus in the Phenacoccini, Pseudococcidae, with an indication of close relationship to Volvicoccus Goux.

Colobopyga Bréthes, 1912, Buenos Aires Mus. Nac. de Hist. Nat. An. $23: 279$.

TYPE-SPECIES : Colobopyga magnani Bréthes, 1912, by monotypy.

This genus remained a puzzle for years after its description, with Sasscer, 1915: 30, assigning it incorrectly to the Tachardiinae. Final assignment came only in recent years, when Ferris, 1952: 3, primarily on the foundation of Stickney's 1934 work on the Phoenicococcinae, concluded that the genus was identical with Palmaricoccus Stickney, 1934, which it antedated.

Columella Šulc, 1936, Ceskoslov. Zool. Spolec. Věst. (1935̃) 3: 65.

From the usage, this is rather certainly a lapsus for Columnea TargioniTozzetti.

$208-496-66-4$ 
Columna Signoret, 1877, Soc. Ent. de France Ann. (ser. 5) 6:658.

Signoret presented this name only as "Columna Targ.-Tozz,=Ceroplastes." Since he used Columnea elsewhere, it seems correct to conclude that Columna was a lapsus for Columnea. Columna was preoceupied in 1811 in the Mollusca, according to Neave, 1939, Nomen. Zool. I : 806.

Columnea Targioni-Tozzetti, 1866, R. Accad. dei Georg. Atti (n. s.) 13: 131, 138, 142; 1867, Soc. Ital. di Sci. Nat. Mem. 3 (3) : 11.

TYPE-SPECIES : Coccus caricae Fabricius, 1794, by subsequent restriction.

The proposer of this name originally presented it as a substitute for Ccroplastes Gray and included in the genus 10 species names, several of which he offered as substitutes for already published, available names. Subsequently, 1867: 11, he deliberately restricted the use of Columnea to Coccus caricae Fabricius, and assigned the other species to the genus Ceroplastes. All of his inclusions that have been recognized are currently assigned to Ceroplastes, but we consider that Columnea might be available if Ceroplastes should be split into smaller generic units.

Comstockaspis MacGillivray, 1921, The Coccidae, p. 391.

TYPE-SPECIES: Aspidiotus perniciosus Comstock, 1881, by original designation.

There has been some variation of opinion on the status of this genus in recent years. Silvestri, 1939: 841, made use of it in his Compendio, and Bodenheimer, 1952: 341, argued in favor of its use. Ferris, 1937e: 50, 53, 56, first assigned the name to synonymy under Forbesaspis MacGillivray, but later, 1938a: SII-255, placed both names as synonyms of Quadraspidiotus MacGillivray. Balachowsky, 1950b : 397 , followed the Ferris assignments.

Comstockiella Cockerell, 1896, Ill. State Lab. Nat. Hist. 4: 320.

TYPE-SPECIES: Aspidiotus sabalis Comstock, 1883, by original designation and monotypy.

Cockerell established this genus in a purely negative fashion by proposing it for Aspidiotus sabalis Comstock because "Comstock's excellent description and figures show that it is not Aspidiotus." Subsequent critical mention seems to have been restricted to various observations by Ferris, especially in 1938a: SII212-213, who characterized the genus and redescribed the trpe-species on the basis of examples from Texas. He strongly questioned the aspidiotine affinities of the genus but left it in the Aspidiotini. Brown, 1957: 362, and $1960: 160-162$, commented on the strong digression of the chromosome pattern from the aspidiotine standards now known. Altogether, it seems doubtful that this genus associates with any aspidiotine genera, but no satisfactory assignment has thus far been found.

Conchaspis Cockerell, 1893, Jamaica Bot. Dept. Bul. (March 1893) 40: 9; 1893, Gard. Chron. (May 1893) 13:548.

TYPE-SPECIES : Conchaspis angraeci Cockerell, 1893, by monotypy.

In both citations Cockerell presented genus and species names as new. Mamet. 19.54h: 190, in his thorough review of the Conchaspididae, accepted the genus as based on the Jamaica Bot. Dept. Bul. citation, and reviewed its status as the 
single genus included in the family which he accepted as properly segregated from, but closer to, the Diaspididae than to other coccids. We concur on both points.

Conifericoccus Brimblecombe, 1960, Queensland Jour. Agr. Sci. 17 : $185-186$.

TYPE-SPECIES: Conifericoccus invaginatus Brimblecombe, 1960, by original designation.

The describer included two additional species in this genus which he assigned to close relationship with the margarodid genus Matsucoccus Cockerell.

Conofilippia Brain, 1920, Bul. Ent. Res. 11: 25.

TYPE-SPECIES : Conofilippia subterranea Brain, 1920, by original designation and monotypy.

The proper association of this genus within the Coccidae (str.) has never been studied critically. Lindinger, 1928: 107, and 1937:182, assigned the name as a synonym of Parafairmairea [Lindinger spelling], but Borchsenius, 1957: 133, stated that this synonymy is not correct.

Contigaspis MacGillivray, 1921, The Coccidae, p. 309.

TYPE-SPECIES : Chionaspis subnudata Newstead, 1912, by original designation.

The author erected this genus in the Diaspidini. It has generally been accepted as ralid. Its status was discussed by Hall, 1946a, and Balachowsky, 1954e, who assigned it to his Diaspidina, chionaspiform complex. Borchsenius and Williams, 1963, Brit. Mus. (Nat. Hist.) Ent. Bul. 13: 360, confirmed its validity and placed it in a group of genera consisting of Sclopetaspis MacGillivray, Unachionaspis, MacGillivray, Balaspis Hall, Neochionaspis Borchsenius, Artemisaspis Borchsenius, and Aloaspis Williams.

Cooleyaspis MacGillivray, 1921, The Coccidae, p. 308.

TYPE-SPECIES : Chionaspis praelonga Newstead, 1920, by original designation and monotypy.

Hall, 1946a: 510-511, accepted and discussed this genus of the Diaspidini. Borchsenius and Williams, 1963, Brit. Mus. (Nat. Hist.) Ent. Bul. 13: 360-364, noted that it is very close to Rolaspis Hall and Voraspis Hall.

Coricoccus Mahdihassan, 1933, [Paris] Acad, des Sci. Compt. Rend. $196: 562$.

TYPE-SPECIES: Coricoccus ornatus proposed as a substitute for Cerococcus ornatus Green, 1909, by original implication.

The proposer of this genus based it, in his original treatment, not on any observable morphological characteristics but on the reaction of the secretionary cover of its presumed type, ornatus, to various chemical solvents plus the general nature of the associated internal symbionts (said to be bacterial). We are in some doubt if the genus can be accepted as validly described under Article 24(b) of the 1961 Code of Zoological Nomenclature. Certainly it does not meet fully the requirements of Article $13(\mathrm{~b})$ of that Code. Nevertheless, it has entered coccid literature, even if somewhat uncertainly, since Lindinger, 1937: 182, recorded it with ornatus as type, and Borchsenius, 1960d : 104, accepted it, although perhaps uncritically, as a legitimate member of the Indo-Malaysian coccid fauna. 
The zoological ralidity of the genus is brought into further question by its proposer's treatment of a second species, Cerococcus hibisci Green, which he included. If we have correctly understood his initial 1933 discussion (in French), he con. sidered that ornatus and hibisci may be separated by differences in the beharior of their secretionary coverings in relation to various wax solvents, that of hibisci dissolving on treatment, that of ornatus remaining resistant to wax solvents, even under heat treatment. In contrast to this described difference, Mahdihassan, 1946a : 197, stated that "both these species . . . do not produce wax." In this $1946 \mathrm{a}$ note, the forms were discussed under the generic names Ceriococcus and Coriococcus, which we accept as unintentional variants of the original Coricoccus.

Coriococcus Mahdihassan, 1946, Current Sci. [India] 15: 197.

The author used this name to refer to the genus and two included species presented by him as Coricoccus in 1933: 562. Lindinger, 1937: 182, stated, "Coriococcus = Coricoccus."

Cornoculus Ferris, 1955, Atlas of the Scale Insects of North America, $7: 81$.

TYPE-SPECIES : Cornoculus oculatus Ferris, 1955, by original designation and monotypy.

The describer placed this genus in the Dactylopiidae as he recognized this family, and indicated close relationship to Gymnococcus Douglas, as defined by Ferris, 1955a : 178.

Cornuaspis MacGillivray, 1921, The Coccidae, pp. 274, 286.

TYPE-SPECIES : Mytilaspis ocellata Green, 1907, by original designation.

This genus seems to have doubtful zoological validity. Lindinger, 1937: 182, said: "=Mytilococcus Amerling [Lepidosaphes]," and Ferris, 1937a: 4, considered its status doubtful. Balachowsky, 1954e: 28, placed the name as a synonym of Lepidosaphes Shimer.

Coronaspis MacGillivray, 1921, The Coccidae, pp. 312, 362.

TYPE-SPECTES : Chionaspis coronifera Green, 1905, by original designation.

The describer placed this genus in the Diaspidini. Ferris, 1937a: 3, indicated that it is distinct from Chionaspis Signoret. Hall, 1946a: 511, 546, accepted it as a valid genus. Balachowsky, 1954e : 23, assigned it to his Lepidosaphedina.

Corylocecis Amyot, 1847, Soc. Ent. de France Ann. (ser. 2) 5: 502.

A uninomial designation proposed as a replacement for a proper binomial for the species discussed. This appears to be Coccus coryli Linnaeus, 1758, the identity of which is confused in European coccid literature. We do not consider that this name has proper status as representing a generic unit, but it is included in Neave, 1939, Nomen. Zool. I : 844.

Cosmococcus Borchsenius, 1959, Ent. Obozr. 38: 842-843.

TYPE-SPECIES: Cosmococcus erythrinae Borchsenius, 1959, by original designation.

The describer placed this genus in the Lecaniodiaspididae, which he separated from the Asterolecaniidae as a new family. 
Cossus Řeháček, 195̌9, [Bratislava] Biologia 14: 625 .

A lapsus for Coccus Linnaeus.

Costalimaspis Lepage, 1937, [Sao Paulo] Inst. Biol. Arch. 8: 239.

TYPE-SPECIES : Costalimaspis eugeniae Lepage, 1937, by original designation.

The describer placed this genus close to Gymnaspis Newstead. Subsequent publication by students of the Coccoidea, including Ferris, 1938b: 57-58; Silvestri, 1939: 801-802; and Lindinger, 1943b: 218, accepted it as zoologically valid in the Diaspidini.

Crassaspis Ferris, 1941, Atlas of the Scale Insects of North America (ser. 3) [v. 3] : SII-274.

TYPE-SPECIES : Pseudodiaspis multipora Ferris, 1919, by original designation. The describer placed this genus in the Diaspidini.

Credodiaspis MacGillivray, 1921, The Coccidae, pp. 313, 366.

TYPE-SPECIES : Cryptodiaspis limuloides, Lindinger, 1909, by original designation and monotypy.

The describer assigned this genus to his Diaspidini. Lindinger, 1937: 182, placed the name as a synonym of Cryptodiaspis Lindinger, 1909. Hall, 1946a:

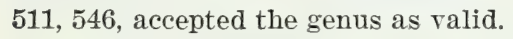

Crenulaspidiotus MacGillivray, 1921, The Coccidae, pp. 389, 426.

TYPE-SPECIES: Chrysomphalus (Melanaspis) portoricensis Lindinger, 1910, by original designation and monotypy.

Lindinger, 1937 : 182, placed this name as a synonym of Melanaspis Cockerell, 1897. Ferris, 1941d: SII-347, agreed, as did Balachowsky, 1951: 578 .

Cribrolecanium Green, 1921, Ann. and Mag. Nat. Hist. (ser. 9) 8:639.

TYPE-SPECIES : Cribrolecanium formicarum Green, 1921, by original designation.

The species included in this genus are rather specialized Coccidae (str.) living under peculiar conditions.

Criniticoccus Williams, 1960, Brit. Mus. (Nat. Hist.) Ent. Bul. 8: 391.

TYPE-SPECIES: Criniticoccus ficus Williams, 1960, by original designation.

The describer indicated for this genus a close relationship with Dysmicoccus Ferris in the Pseudococcidae.

Criococcus Rutherford, 1915, Spolia Zeylanica 10:110.

A lapsus for Eriococcus Targioni-Tozzetti.

Crisicoccus Ferris, 1950, Atlas of the Scale Insects of North America (ser. 5) $[$ จ. 5$]: 45$.

TYPE-SPECIES: Dactylopius pini Kuwana, 1902, by original designation and monotypy.

The describer indicated the close association of this genus with Planococcus Ferris in the Pseudococcidae. Its zoological validity has been confirmed by Ezzat and McConnell, 1956: 3, 13, 22, and by Takahashi, 1958: 3. 
Crocidocysta Rübsaamen, 1894, Berlin. Ent. Ztschr. 39: 218.

TYPE-SPECIES : Crocidocysta froggatti Rübsaamen, 1894, by monotypy.

There seems to be no question that this name is a synonjm of Cylindrococcus Maskell, 1892, and that the trpe-species is identical with C. amplior Maskell, 1893. Lindinger, $1910: 156$, and 1931a : 114, alleged that $C$. froggatti Rübsaamen was a psyllid but emended this riew, 1937: 182, to indicate that Crocidocysta Rübsaamen partim equaled Cylindrococcus Maskell.

Crossotosoma Douglas, 1890, Ent. Monthly Mag. 26: 79.

TYPE-SPECIES : Crossotosoma aegyptiacum Douglas, 1890, by monotypy.

This name has long been accepted as a synonym of Icerya Signoret, 1875 .

Cryptaonidia Neave, 1939, Nomen. Zool. I: 884.

A lapsus for Cryptoaonidia Leonardi.

Cryptaspidiotus Lindinger, 1910, Ztschr. f. Wiss. Insektenbiol. $6: 156$.

TYPE-SPECIES : Chrysomphatus barbusano Lindinger, 1908, by original indication and monotypy.

The type association of this genus has received some complicated treatment. Although proposed originally for Chrysomphalus barbusano, and for this only, Lindinger, 1931a: 10, in listing the genus said: "Typ: aonidioides n. sp." Later he, 1937: 182, gave barbusano as the type of the genus. Ferris, 1937e: 51, 53, complicated the matter by listing the type-species as mediterraneus Lindinger, but later in the same year, 1937d: 106, he too specified barbusano. MacGillivray, 1921: 426, included only mediterraneus Lindinger in his treatment of the genus. Balachorsky, 1948b: 269, accepted the genus as zoologically ralid and assigned it to his Aonidina.

Cryptaspidus Lindinger, 1910, Jahrb. der Hamburg. Wiss. Anst. (1909) 27 Beih. $3: 43$.

TYPE-SPECIES: Cryptaspidus nucum Lindinger, 1910, by monotypy.

The describer, 1957: 543, offered the opinion that this genus is the "cryptogynous" form of Pseudoparlatoria Cockerell.

Cryptes (Crawford MS) Maskell, 1892, New Zeal. Inst. Trans. and Proc. (1891) 24:21, nomen nudum; Cockerell and Parrott, 1899, Industrialist $25: 162$.

TYPE-SPECIES : Lecanium baccatum Maskell, 1892, by subsequent designation by Cockerell and Parrott, and monotypy.

The authorship and date of publication above are presented in Neave, 1939, Nomen. Zool. I : sst. Fernald, 1903b: 209, credited the genus to Cranford, and the type species to Maskell. Assignment of author and publication date has varied in the few recent references that mention the genus.

Following his description of baccatum, Maskell noted that "Cryptcs baccata" was a manuscript name attached by Crawford to the specimens on which Lecanium baccatum Maskell was based. This seems to us to make Cryptes a nomen nudum under the negative restrictions of Article 11(d) of the 1961 Code, as artually, thom perhaps not formally, publication in synougmy. Te have 
failed to find in the 1961 Code any solid support for the acceptance of Maskell 1892 as the proper author and date combination to associate with the name Cryptes. Morrison and Morrison, 1922: 80, discussed this matter when they redescribed baccatum, and concluded that the first positive use of Cryptes as a coccoid genus occurred in the 1899 Cockerell and Parrott reference. Publication of this opinion brought a prompt protest from Professor Cockerell, but no citation of Code provisions of that day that would justify his stand. Although not a precisely parallel situation, perhaps Opinion 268 (1954) of the International Commission, involving the genus Aspidoproctus, can be stretched to support the Neare interpretation of authorship and date for Cryptes. Otherwise, we think the name should be credited to Cockerell and Parrott, 1899, with type-species Lecanium baccatum Maskell, 1892, by subsequent designation and monotypy. There appears to have been no critical assignment of this genus within the Coccidae (str.).

Crypthemichionaspis Lindinger, 1910, Ztschr. f. Wiss. Insektenbiol. 6: 192, nomen nudum; 1911, $7: 175$.

TYPE-SPECIES: Crypthemichionaspis nigra Lindinger, 1911, by subsequent designation of Sasscer, 1912: 91.

Lindinger established this genus for certain Australian species, including the type-species, but by 1937: 182, had concluded that the name should stand as a synonym of Anamefiorinia Leonardi, 1906. Ferris, 1936a: 21, 26, considered it to be a synonym of Trullifiorinia Leonardi, 1906, but later, 1941a: 12, left the question of zoological distinctness of the genus open to further investigation.

Crypticerya Cockerell, 1895, Psyche (1891-1896) (sup.) $7: 15$.

TYPE-SPECIES : Icerya rosae Riley and Howard, 1890, by original designation and monotypy.

The describer indicated a relationship to Icerya Signoret. See Morrison, 1928: 200 , for information on included species and the position of the genus in the Margarodidae.

Cryptinglisia Cockerell, 1900, The Entomologist 33: 173.

TYPE-SPECIES : Cryptinglisia lounsburyi Cockerell, 1900, by monotypy.

The describer indicated a relationship to Inglisia Maskell in the Coccidae (str.). There seems to have been no further discussion of this; even Brain, 1920a : 38, confined himself to copying the original description.

Cryptoaonidia Leonardi, 1899, Sistema delle "Parlatoriae" Nota Preventiva. Florence Mariani, p. 5 (separate) ; 1900, Riv. di Patol. Veg. 8:207, 323.

TYPE-SPECIES : Aspidiotus hakeae Maskell, 1896, by original designation and monotypy.

This name is a synonym of Phautaspis Leonardi, 1897, because the two genera have the same type-species. Balachorsky, 1948b: 268, mentioned this name (spelled Cryptaonidia) as one of the proper inclusions in his Aonidina. The type-species was redescribed under Phaulaspis by Morrison and Morrison, 1922 : 89 . 
Cryptococcus Douglas, 1890, Ent. Monthly Mag. 26: 155.

TYPE-SPECIES: Coccus fagi Baerensprung, 1849, by original designation and monotypy.

Lindinger, 1936a: 444, showed that the type-species was preoccupied by Coccus fagi Sulzer, 1776, and offered as a replacement the name Cryptococcus fagisuga Lindinger, 1936. Ferris, 1955a : 83 ; Balachowsky, 1948b : 254; Schmutterer, 1952 : 405-406, 417; and Borchsenius, 1949: 370-371, placed this genus in the Eriococcidae (Dactylopiidae of Ferris, 1955a), and Hoy, 1963, New Zeal. Dept. Sci. and Indus. Res. Bul. $150: 8$, confirmed this assignment.

Cryptodiaspis Lindinger, 1909, Jahrb. der Hamburg. Wiss. Inst. (1908) 26 Beih. $3: 26$.

TYPE-SPECIES : Cryptodiaspis conservans Lindinger, 1909, by subsequent designation by Sasscer, 1911 : 69.

The author erected this genus for three African diaspidine species. Hall, 1946a : 511, considered the genus zoologically valid on the basis of the published notes but without examination of specimens.

Cryptohemichionaspis Ferris, 1941, Microentomology $6: 16$.

A lapsus for Crypthemichionaspis Lindinger. This spelling was presented on the plate figure showing the trpe-species with the correct spelling in the text. Takahashi, 1956a : 58, also used this misspelling.

Cryptokermes Hempel, 1900, Rev. MLus. Paulista [Sao Paulo] 4: 380. 398.

TYPE-SPECIES: Cryptokermes brasiliensis Hempel, 1900, by original designation and monotypy.

The proper assignment of this genus in the existing system of coccoid classification was discussed in detail by Morrison, 1928: 100, who placed it in the Margarodidae.

Cryptoparlatorea Lindinger, 1905, Insekten Börse 22 : 132.

TYPE-SPECIES : Cryptoparlatorea leucaspis Lindinger, 1905, by original designation and monotypy.

This genus has been discussed by several recent coccid writers under the name Cryptoparlatoria; see discussions of Parlatoria Targioni-Tozzetti and Parlatorea Lindinger. Lindinger, 1937: 183, said "=Apteronidia Berl." Balachowsky, 1958b : 315, among others, accepted it as valid, as Cryptoparlatoria.

Cryptoparlatoreopsis Borchsenius, 1947, Akad. Nauk SSSR Dok. (n.s.) $58: 343-344$.

TYPE-SPECIES : Aonidia halli Bodenheimer, 1929, by original designation and monotypy.

The describer indicated a relationship with "Parlatoreopsis MacG." See Parlatoreopsis Jindinger. Balachowsky, 19-8b: 232, 240-24s, assigned the Borchsenius genus to the Aspidiotini, Aonidina. 
Cryptoparlatores Takagi, 1960, Insecta Matsumurana 23: 71.

A lapsus for Cryptoparlatorea Lindinger.

Cryptoparlatoria Kuwana, 1917, A Check List of the Japanese Coccidae, p. 18.

An emendation of Cryptoparlatorea Lindinger. MacGillivray, 1921: 248, 253, 481, used both spellings. Balachowsky, 1958b: 315, who used this spelling, placed the genus in his Parlatorina.

Cryptoparlatyrea Lindinger, 1934, Ent. Anz. 14: 15.

A lapsus for Cryptoparlatorea Lindinger.

Cryptophyllaspis Cockerell, 1897, U.S. Dept. Agr., Div. Ent., Tech. Ser. $6: 14$.

TYPE-SPECIES : Aspidiotus occultus Green, 1896, by original designation and monotypy.

Leonardi, 1897a: 375, may have antedated Cockerell's publication of this name when he published a brief note on the disposition of various names that Cockerell had presented in a letter addressed to Leonardi. He placed Cryptophyllaspis as a synonym of Aspidiotus Bouché, and Lindinger, 1937, 183; Ferris, 1941e: 35, 37; and Balachowsky, 1948b: 273, have accepted this synonymy.

Cryptorhizococcus Green, 1918, Ann. Appl. Biol. 5: 150, nomen nudum; Lindinger, 1937, Ent. Jahrb. 46: 183.

TYPE-SPECIES : Cryptorhizococcus oleariae Green, 1918, by subsequent designation of Lindinger, 1937: 183.

Both these names lack nomenclatorial and zoological status.

Cryptoripersia Cockerell, 1899, in Ehrhorn, Canad. Ent. 31: 5; Cockerell, 1899, Canad. Ent. 31: 278.

TYPE-SPECIES : Ripersia arizonensis Ehrhorn, 1899, by original designation and monotypy.

Ferris, 1953a: 307,310 , stated that arizonensis was a synonym of Ripersia trichura Cockerell, 1901, but the exact opposite should have been stated. Ferris placed this as an aberrant genus in the Pseudococcidae.

Cryptoselenaspidus Lindinger, 1910, Ztschr. f. Wiss. Insektenbiol. $6: 259$.

TYPE-SPECIES : Cryptoselenaspidus serra Lindinger, 1910, by monotypy.

Its proposer suggested that the second stage of this insect shows a similarity to the adult of Selenaspidus silvaticus Lindinger. The adult female remains enclosed within the second stage. Despite this implied relationship, the genus was not considered by Mamet, 1958a, in his review of the Selenaspidus conplex, nor was it mentioned by Balachowsky, $1958 \mathrm{~b}$, in his coverage of the remaining aspidiotine genera from central Africa. Available information on it is confined to the original description. 
Cryptostigma Ferris, 1922, Canad. Ent. 54: 160.

TYPE-SPECIES : Cryptostigma ingae Ferris, 1922, by original designation and monotypy.

Ferris subsequently (in lit.) concluded that this new species was identical with Pseudophilippia inquilina Newstead, 1920, described from Jamaica, but this, while quite possible, has not been confirmed by an examination of Newstead's types. C. ingae Ferris, published Oct. 12, 1922, is clearly identical with Alicrmes secretus Morrison, published before October 1, 1922. Morrison, 1929: 53, discussed this. The species properly assignable to this genus associate with New World genera such as Toumeyella Cockerell within the Coccidae (str.).

Crysomphalus Martins, 1961, Gazeta de Agricole de Angola 6 : 203.

A lapsus for Chrysomphalus Ashmead.

Ctenochiton Maskell, 1879, New Zeal. Inst. Trans. and Proc. (1878) 11: 208.

TYPE-SPECIES : Ctenochiton viridis Maskell, 1879, by subsequent designation of Fernald, $1903 \mathrm{~b}: 159$.

The describer compared this genus only with certain genera now placed in the Asterolecaniidae, but, on the basis of the indicated type-species, it seems clearly to assign to the Coccidae (str.). The genus and its type-species were redescribed by Morrison and Morrison, $1922: 71$.

Cucullococcus Ferris, 1941, Microentomology $6: 25-26$.

TYPE-SPECIES: Cucullococcus vaccinii Ferris, 1941, by original designation and monotypy.

The describer placed this genus in the Psudococcidae and suggested a relationship with Ehrhornia Ferris.

Cupidaspis MacGillivray, 1921, The Coccidae, p. 312.

TYPE-SPECIES: Leucaspis cupressi Coleman, 1903, by original designation and monotypy.

This name is accepted as a synonym of Lineaspis MacGillivrar. 1921, br recent coccid workers including Ferris 1936a: 19, 21, 24-25, and 1937: SI-77-78; Lindinger, 1937 : 183 ; and Balachowsky, 1954e : 401.

Cupressaspis Borchsenius, 1962, Ent. Obozr. 41: 866-869.

TYPE-SPECIES : Cupressaspis isfarensis Borchsenius, 1962, by original designation.

The author placed this genus close to Aonidia Targioni-Tozzetti and noted that all members of the genus live on coniferous plants of the Cupressinae.

Cupulinia Signoret, 1875, Soc. Ent. de France Ann. (ser. 5 ) $5: 40$.

A lapsus for Capulinia Signoret.

Curycerus Targioni-Tozzetti, 1867, Soc. Ital. di Sci. Nat. Mem. 3 (3): 19.

A lapsus for Ericcrus Guérin-Méneville. 
Cyclococcus Ferris, 1950, Atlas of the Scale Insects of North America (ser. 5) [v.5]: 116, nomen nudum.

Ferris presented this name as "Cycloccoccus balteatus (Green)" without further information that might authenticate it in terms of the post-1930 requirements of the 1961 Code of Zoological Nomenclature. The species involved was described in Phenacoccus Cockerell and is presently assigned to Peliococcus Borchsenius.

Cyclolecanium Morrison, 1929, Ent. Soc. Amer. Ann. 22 : 56.

TYPE-SPECIES: Cyclolecanium hyperbaterium Morrison, 1929, by original designation and monotypy.

The describer placed this genus in the Coccidae (str.) and indicated a possible relationship with the Toumeyella Cockerell series of genera.

Cylindrococcus Maskell, 1892, New Zeal. Inst. Trans. and Proc. (1891) $24: 41$.

TYPE-SPECIES: Cylindrococcus casuarinae Maskell, 1892, by subsequent designation by Fernald, 1903b : 84.

The type-species of this genus was redescribed by Morrison and Morrison, 1922 : 26, with an indication that the genus was "possibly Eriococcine." It was also redescribed by Froggatt, 1933: 374. Balachowsky, 1942: 39, 44, placed the genus in a new family, the Cylindrococcidae, along with other genera he considered related. Ferris, $1957 \mathrm{c}: 85$, assigned it to the Eriococcidae and this was accepted by Hoy, 1963, New Zeal. Dept. Sci. and Indus. Res. Bul. 150 : 8.

Cynodontaspis Takagi, 1961, Insecta Matsumurana 24: 42, nomen nudum; 1962, 25: [46]-48 (validated).

TYPE-SPECIES : Cynodontaspis piceae Takagi, 1962, by original designation and monotypy.

The describer assigned this genus to the Diaspidini.

Cyphococcus Laing, 1925, Bul. Ent. Res. 16 : 56.

TYPE-SPECIES : Cyphococcus caesalpiniae Laing, 1925, by original designation and monotypy.

The describer placed this genus in the Coccidae (str.) without closer association.

Cyphoma Gistel, 1848, Naturgeschichte des Thierreichs, Stuttgart, p. 151.

TYPE-SPECIES : Cyphoma characias [Bose d'Antic, 1784], by monotypy.

The type-species of the genus is accepted to be identical with Orthezia urticae (L.), so in this usage Cyphoma is a synonym of Orthezia Bose d'Antic. It was used in the Mollusca in 1798 and in 1807.

Cystococcus Fuller, 1897, West. Austral. Bur. Agr. Jour. 4: 1346.

TYPE-SPECIES : Cystococcus echiniformis Fuller, 1897, by monotypy.

The describer placed this genus in the Brachyscelinae of Maskell. Cockerell, 1902g: 114, and Fernald, 1903b:48, assigned the name as a synonym of Ascelis 
Schrader. Froggatt, 1921a: 156, accepted the genus as ralid, but placed its typespecies as a synonym of Brachyscelis pomiformis Froggatt, 1892. There appears to be no recent contribution to its status.

Dactylaspis Ferris, 1937, Atlas of the Scale Insects of North America (ser. 1) [ . 1]: SI-26.

TYPE-SPECIES : Dactylaspis dactylifera Ferris, 1937, by original designation.

The describer placed four species in this genus and assigned it to the Diaspidini. Balachowskr, 195te: 23. listed it as belonging to his group Lepidosaphedina, but subsequently (p. 172) included it in a group of genera which he assigned to his Diaspidina chionaspiform.

Dactylopius O. G. Costa, $1835,{ }^{6}$ Fauna del Regno di Napoli, Famiglia de’ Coccinigliferi, o de’ Gallinsetti, Emitteri Napoli, pp. 2, 1 .

TYPE-SPECIES : ?Coccus adonidum [Linnaeus 1758] by subsequent designation of Targioni-Tozzetti, 1866: 129, or Dactylopius coccus Costa, 1835, by subsequent designation of Cockerell, 1902k: 453. (This is Coccus sativus Lancry, 1791, according to Lindinger, $1949: 211$.)

Aside from the complications surrounding the fixation of the proper date of publication for this genus, our examination of its beginnings showed serious complications in other areas. Costa, footnote (page 2) stated unequirocally that he ras substituting this name for the nomenclatorially less exact name Diaprosteci, which he, 1828a: 7 , had proposed along with two other currentls accepted genera, for the reception of coccids haring the body dirided into 13 segments, each with lateral appendages, such as Coccus adonidum. Since this is the only coccid species he mentioned under Diaprosteci, it is type by monotypy. Since Costa, 1835: 2, deliberatels substituted Dactylopius for Diaprosteci, the trpespecies of Dactylopius would stand as Coccus adonidum by substitution. However, adonidum receired only the briefest incidental mention in the Fauna Napoli paper, and nearly all of the discussion under Dactylopius in this paper related to two species which Costa called Dactylopius coccus [the Mexican cochineal] and Dactylopius polonicus [the Polish cochineal].

The first subsequent comment on Dactylopius and Diaprosteci seems to have been made by Testwood, $1810: 44 \bar{i}$, who accused Costa of promoting nomenclatorial confusion through proposal of these names [ Testwood substituted Diaprostocetus for Diaprosteci], but made no direct critical effort to establish the status of either genus. Targioni-Tozzetti, 1866:129, made the first type-species designation for this genus that has been encountered, citing adonidum as the proper type-species. His proposal fitted the sequential pattern from Diaprosteci through Dactylopius but was predicated on his assignment of Coccus cacti of authors, non Linnaeus, as the type-species of the genus Coccus Linnaeus, a concept already rejected (see Coccus). At the same time he ruled out the use of the genus name Pseudococcus Westwood, 1840, for this mealybug concept on the grounds of prior publication of Dactylopius. Signoret and subsequent authors followed this association for some 60 years so that many species currently placed in the Psendococcidae were originally described under the generic namp Dactylopius.

The next pronouncement on type fixation aplarently was by Cockerell, 1902k : 453-454, who allegedly reviewed the history of Dactylopius and stated: "D.

'See footnote on Calimmata Costa. 
coccus Costa ... which is the first mentioned is to be regarded as type of the genus. D. coccus is said to be Coocus cacti L., but instead of being a synonym of that species (Monophlebus cacti [see 1899j: 261]), it is the first available name for the commercial cochenille." This statement ignored the previous potential type fixation through the substitution of Dactylopius for Diaprosteci and the actual previous type fixation by Targioni-Tozzetti, but it was accepted by Fernald $1903 \mathrm{~b}$, and seems to have had substantial usage subsequently by critical students of coccid taxonomy, with the exception of Green, 1912a, and MacGillivray, 1921. Lindinger, 1937: 182, accepted Dactylopius as valid for his list of coccid genera. Laing, 1944: 93, discussed the name in connection with his comment on the genus Pseudococcus Westwood, as did Ferris, 1950b: 170, and 1955a: 85. Kirkaldy, 1904a : 254, and 1906a: 254, presented various observations on the status and type of this genus but his opinions do not seem to be significant or, indeed, germaine to the alignment of the genus.

It is our opinion that the zoological concept of this genus as standing for the Mexican cochineal and its relatives is now sufficiently established in taxonomic literature to make its continued use as the accepted designation for these coccids highly desirable. But a decision in its favor under the Plenary Powers of the International Commission is clearly required to make its use valid.

Dactylopus Signoret, 1875, Petites Nouvelles Ent. 7 : 499.

This name was printed in Signoret's description of Dactylopus bromeliae n. sp. We consider it to be a lapsus for Dactylopius O. G. Costa, which was then in use for the mealybug genus now called Pseudococcus Westwood.

Daraspis Hall, 1946, Roy. Ent. Soc., London, Trans. 97 : 511.

TYPE-SPECIES : Chionaspis bussii Newstead, 1911, by original designation and monotypy.

The proposer of this genus suggested a relationship to Sinistraspis MacGillivray. Balachowsky, 1954e: 23, 172, suggested two different assignments for it, the first in Lepidosaphedina, the second in Diaspidina, group II, chionaspiform.

Dattilopii O. G. Costa, 1835, Fauna del Regno di Napoli, Famiglia de' Coccinigliferi, o de' Gallinsetti. Emitteri Napoli, p. 2.

Costa presented this italicized and capitalized name as one of the "three distinct genera" into which he divided the coccid group. It has never attained standing in coccid literature and may actually be a vernacular name.

Decoraspis Ferris, 1955, Microentomology $20: 31-32$.

TYPE-SPECIES : Aonidia cornigera Green, 1896, by original designation.

This name was proposed by Ferris as a replacement for Greeniella "MacGillivray 1921: 395." In our opinion this was an unnecessary proposal since MacGillivray, 1921: 395, actually stated "Greeniella Ckll." [1897]. Thus Decoraspis is a synonym of the Cockerell name. See Greeniella MacGillivray.

Delococcus Ferris, 1955, Microentomology $20: 5$.

TYPE-SPECIES: Formicoccus tafoensis Strickland, 1947, by original designation.

This was placed in the Pseudococcidae. 
Dentachionaspis MacGillirray, 1921, The Coceidae, p. 310.

TYPE-SPECIES : Chionaspis capensis Newstead, 1917, by original designation and monotypy.

Hall, 1946a: 499, 512, 542,546 , accepted this genus as valid zoologically but stated that the type-species ras identical to Dinaspis lounsburyi Leonardi, 1914. Balachorsky, 1954e: 172, accepted the genus and placed it in his Diaspidina, group II, chionaspiform.

Dentaspis MacGillivray, 1921, The Coccidae, p. 312.

TYPE-SPECIES : Chionaspis substriata Newstead, 1910, by original designation and monotypy.

Hall, 1946a: 499, 542, 546, accepted this as a zoologically ralid genus. Balachowsky, 1954e: 171, placed it in his Diaspidina, group II, chionaspiform.

Dermatolecanium Lindinger, 1937, Ent. Jahrb. $46: 183$.

An emendation of Dermolecanium Zavattari.

Dermolecanium Zavattari, 1928, in Casazza, Bol. della Soc. Med. Chir. $42: 419$.

TYPE-SPECIES : Dermolecanium migrans Zavattari, 1928, by monotypy.

A claim was made that the larvae on which the description is based belong to the lecanine series of the Coccidae (str.). The report associated with the description of the new genus and species made the most unusual claim that the coccids were responsible for a serious skin injury to a human being. Silvestri, 1939: 769, commented on this report, and seemed inclined to accept the evidence at face ralue. We have examined the report carefully and feel that too many mexplained factors are present to give it full credence as evidence that this insect, presumbably belonging in a plant-feeding group, actually attacked and damaged human skin. We suspect some explanation other than active attack by the coccid may have accounted for the presence of the larvae in association with the lesions.

Desmococcus McKenzie, 1942, Microentomology $7: 7$.

TYPE-SPECIFS : Desmocaccus captivus McKenzie, 1942, by original designation.

The describer placed this genus in the new tribe Pitycoccini, Coelostomidinae, Margarodidae.

Diaonidia Takahashi, 1956, Insecta Matsumurana 20: 25.

TYPE-SPECIES: Aonidia yabunikkei Kuwana, 1933, by original designation and monotypy.

The describer offered characters to separate this genus from Aonidia TargioniTozzetti.

Diaphoraspis Brimblecombe, 1957, Queensland Jour. Agr. Sci. 14: 277.

TYPE-SPECIES: Diaphoraspis orbata Brimblecombe, 1957, by original designation.

Its describer placed this genus in the Aspidiotini. 
Diaprostecha Targioni-Tozzetti, 1868, (separate) Soc. Ital. di Sci. Nat. Atti 11:4;1869, 11:697.

An emendation or misspelling of Diaprosteci Costa, which has acquired no standing in coccid literature.

Diaprostechus Targioni-Tozzetti, 1868, (separate) Soc. Ital. di Sci. Nat. Atti 11:32;1869, 11:725.

Presumably an emendation of Diaprosteci Costa, since Targioni-Tozzetti credited it to Costa, Pontano [a publication], 1828. It has acquired no standing in coccid literature.

Diaprosteci O. G. Costa, 1828, Prospetto di Tna Nuora Dirisione Metodica del Genere Coccus, Lin. Lam. EC. Napoli, Dalla Tipografia Trani, p. 7.

TYPE-SPECIES : Coccus a donid um Linnaeus, 1758, by monotypy.

Various compilers of lists of animal names, including Sherborn, 1925, Index Animalium, section 2: 1900, hare placed this as a "rernac." name. According to Sherborn, Cockerell, $1902 \mathrm{k}$ : 453, stated that this was given in the Italian rernactlar, and Fernald, 1903: 22, also regarded it as a rernacular name to be disregarded. We are not able to confirm that this is a "vernacular name" as defined in the 1961 Zoological Code. Instead, Diaprosteci appears to us to be dericed from the Greek language, although perhaps poorly formed. For a number of years after its original publication the name appeared in the published works of Targioni-Tozzetti, Signoret, and other workers under a variety of spellings. Nine variations of the name hare been found, and are included in this list.

This generic name was published by its describer in direct association with his Diaspis and Calymmata, which hare been accepted fully in coccid literature. If our understanding of its formation is correct, Diaprosteci is as fully entitled to consideration as are Calymmata and Diaspis. The author, 1835: 1, however. dereloped dissatisfaction with it and, according to his own statement, replaced it with Dactylopius. The author's substitution of Dactylopius for the reason of personal dissatisfaction is not allowable according to Code Article 18 (a). The initial complications here outlined appeared in print well over 100 years ago. In the interrening period, and especially in the past 60 sears, Diaprosteci, in any spelling, has disappeared from coccid literature, while Dactylopius has retained its standing as an available generic name although it has had rarying applications through the years.

Diaprostecie Cockerell, 1902, Ann. and Mag. Nat. Hist. (ser. 7 ) 9: 454 .

Cockerell stated that Costa presented this spelling of Diaprosteci, but we hare been unable to confirm this.

Diaprostecus Waterhouse, 1902, Index Zoologicus, sup. 1: 110.

An emendation of Diaprosteci Costa, credited to Costa, 1827. Lindinger, 1937: 183, repeated this spelling, crediting it to Pontano [a publication], $182 \mathrm{~s}$. 
Diaprostethus Signoret, 1877, Soc. Ent. de France Ann. (ser. 5) 6: 658.

Presumably this is another variation in the spelling of Diaprosteci Costa. Signoret credited it to Costa and indicated that it should be a synonym of Dactylopius Costa, 1835.

Diaprostetus Signoret, 1868, Soc. Ent. de France Ann. (ser. 4) 8: 842.

This spelling was presented in the synonymy Signoret included under Coccus adonidum Linnaeus in his preliminary catalogue of the Coccidae. The name was credited to Costa, 1828.

Diaprostocetus Westwood, 1840, An Introduction to the Modern Classification of Insects 2: 447.

Westwood credited this name to Costa, another change in the spelling of Diaprosteci.

Diapsis Targioni-Tozzetti, 1867, Soc. Ital. di Sci. Nat. Mem. 3 (3): 38,51 .

A lapsus for Diaspis Costa.

Diaspidiotus Berlese, 1896, or Berlese and Leonardi, 1896, in Berlese and Leonardi, Riv. di Patol. Veg. 4: 350; or Leonardi, 1897, Riv. di Patol. Veg. 5 : 375 :

TYPE-SPECIES: Aspidiotus (Diaspidiotus) patavinus Berlese, 1896, by monotypy; or Diaspis ancylus Putnam, 1877, by subsequent designation of Leonardi, 1898a : 50 (210).

This genus presents another of the painfully frequent instances of confusion over the early history and actual status of a coccid generic name. Neave, 1939, Nomen. Zool. II : 63, credited the name to Berlese, 1896, in Berlese and Leonardi, 1896: 350 . This represented the first known publication of the name, which was presented as "6. Aspidiotus (Diaspidiotus) patavinus Berl. n. sp." This heading was followed by a description of the new species. We have found nothing in the 1961 Code of Zoological Nomenclature that would either permit or compel rejection of this publication date and author. Acceptance of this concept, however, repudiates completely the subsequent history of the genus and gives a zoological status other than that currently accepted by many coccid workers.

In 1897a: 375, Leonardi referred to the "subgenus Diaspidiotus already proposed by Prof. Berlese and me" and, in 1898a : 50 (210), in a key, he presented "Diaspidiotus Berl. et Leon., Trpus A. ancylus" and repeated the joint authorship of page 215 of the same paper. Other coccid students of the period, e.g. Cockerell, 1897i: 11, and Newell, 1899: 3-5, also credited the genus to joint authorship. More recent students show variation on assigning authorship and date of publication, where indicated, but pretty consistently accept Diaspis ancylus l'utnam, 1877, as the type-species of the genus. This is not possible if the earlier publication date is accepted since Aspidiotus patavinus Berlese, 1896, which is currently placed by European workers as a synonym of Aspidiotus pyri Lichtenstein, must necessarily be accepted as type-species by monotypy. This was discussed by De Iotto, 1963, Ent. Soc. South. Africa Jour. 26: 144-145, who 
concluded that Diaspidiotus should be credited to Berlese, 1896, and that patavinus Berlese, 1896, =A. pyri Lichtenstein, 1881, is its type-species. Current publications on aspidiotine coccids generally recognize Diaspidiotus, based on Diaspis ancylus Putnam, 1877, as type-species, as a zoologically valid coccid segregate, generically separated from related forms and especially from Quadraspidiotus MacGillivray, 1921, which had Aspidiotus ostreaeformis Curtis, 1843, designated as its type-species.

We believe that the zoological distinction between Diaspidiotus and Quadraspidiotus, as they are now constituted (i.e., each with the type-species indicated and each with numerous included species), can be maintained on present knowledge only with considerable uncertainty. In our view much more critical study of included species would be needed to confirm the zoological separation of these two generic units. If patavinus is accepted as type-species of Diaspidiotus, then Quadraspidiotus clearly becomes a synonym of it. Such synonymy was indicated by Borchsenius, $1950 \mathrm{~b}: 224$. Perhaps this synonymy is valid zoologically as well, even if the currently accepted concept of Diaspidiotus rests on the occurrence of a reduced number of pygidial marginal lobes as compared with Quadraspidiotus. We conclude that a rigid conformity to the applicable Articles of the 1961 Code will disrupt the zoological standards for the genus Diaspidiotus that were established in 1897 and 1898 and that are currently accepted by many active students of the Coccoidea. We further conclude that, in the interest of stability, the genus can best stand as Diaspidiotus Berlese and Leonardi 1897, 1898, with type-species Diaspis ancylus Putnam, 1877, by designation of Leonardi, 1898a: 50 [210].

Diaspidistus Hempel, 1900, [Sao Paulo] Rev. Mus. Paulista 4: 497, 522.

TYPE-SPECIES : Diaspidistus multilobis Hempel, 1900, by original designation and monotypy.

Its describer keyed this genus to a relationship with Diaspis Costa. Cockerell, 1902p: 257, suggested a close affinity with Pseudoparlatoria Cockerell. Lindinger, 1937 : 183, said: "=Pseudoparlatoria Ckll."

Diaspidopus Brimblecombe, 1959, Queensland Jour. Agr. Sci. 16: 129.

TYPE-SPECIES: Diaspidopus distinctus Brimblecombe, by original designation and monotypy.

The describer suggested a relationship to Pseudotargionia Lindinger for this genus.

Diaspis O. G. Costa, 1828, Prospetto di Una Nuova Divisione Metodica del Genere Coccus, Lin. Lam. EC. Napoli, Dalla Tipografia Trani, pp. 6-7, nomen nudum; 1835, Fauna del Regno di Napoli, Famiglia de' Coccinigliferi, o de' Gallinsetti. Emitteri Napoli, p. 19.

TYPE-SPECIES : (Diaspis calyptroides Costa, 1835)=Aspidiotus echinocactus

Bouché, 1833, by subsequent designation of Cockerell, 1902d: 58.

While Diaspis was first proposed by Costa in 1828 , he did not include in it at that time any definitely named species. Therefore it did not acquire status until its appearance in his coccid Fauna of Naples paper, of uncertain date, but here accepted as 1835 ( species for his genera. Targioni-Tozzetti, 1867: 9, stated that the type-species for this genus was Coccus aonidum, or a form that has been confused with $208-496-66-5$ 
others under this name. Costa did not mention this name in his paper. We have found no tie-up that could permit acceptance of this attempted type-species fixation and since the subsequent Targioni-Tozzetti Catalog (1868) offers no confirmation of such a choice of type-species for Diaspis, we conclude that the proposal has no validity.

The first type-species designation with apparent validity that we have encountered, occurred in Cockerell, 1902d:58, where he stated: "The type of Diaspis is D. calyptroides ...." Searches in coccid literature by different workers have brought published opinions that Costa's calyptroides was identical with Coccus luteus Lancry, 1791, and with Aspidiotus echinocacti Bouché, 1833, and the evidence from the description of these forms seems to lend plausible support to the published opinions. Lindinger, 1943c: 249, accepting 1829 as the date of publication of calyptroides Costa, gave it priority over echinocacti Bouché, 1833, but held that both of these species were predated by luteus Lancry, 1791. For more than 60 years the majority of coccid workers have cited echinocacti Bouché, 1833 , as type-species of Diaspis Costa.

The problem of the status of the coccid genus Diaspis seems to be further complicated by its proposal, apparently wholly independently of the Costa publication, by Bremi, or Bremi-Wolf, first in Ver. Schweiz. Naturf. Gesell., 1847: 43, where no species were included, and again, 1849:327, where the species name Diaspis nivea was included. (Lindinger, 1936:167, offered his opinion that this is Chionaspis salicis (L.) Sign.) Diaspis also was used in the Coleoptera in 1848 according to Neave, 1939, Nomen. Zool. II : 63, but the Costa use, whatever the date of its appearance, seems to have ample priority.

With respect to zoological usage, this genus has been applied with relative consistency, especially since the Cockerell type-species and the Fernald Catalogue acceptance, to a group of diaspidine coccids centering on the common armored scale found on many Cactus species. Balachowsky, 1954e: 173, placed this genus in Diaspidina, group I, diaspiform. We believe that this application should be accepted.

Diasprotecus Signoret, 1868, Soc. Ent. de France Ann. (ser. 4) 8:511.

A variation of spelling of Diaprosteci Costa.

\section{Diaste Dalle Torre, 1898, Cat. Hymenopterorum 5 : 220, footnote 3.}

We believe that this name, as listed by Dalle Torre, resulted from an inadequate examination of the paper on North American Aphelinae by L. O. Howard, on which it was based. Howard reported one of his parasites as coming from "Mytilaspis on an orchid, an undetermined species of Dycaste from Japan." Dycaste does not seem to be a recognized plant genus and we are persuaded that the spelling was a lapsus for Lycaste, a well-known orchid genus. This error appears to have been compounded by Morley, 1909, Entomologist 42: 257, in his review of the Hymenopterous Parasites of Coccidae, where he further transposed Diaste into Diaspis.

Diastolaspis Brimblecombe, 1959, Queensland Jour. Agr. Sci. 16:132. TYPE-SPECIES : Diastolaspis novata Brimblecombe, 1959, by original designation and monotypy.

The describer placed this genus close to Pseudotargionia Lindinger. 
Diaulacaspis Takahashi, 1942, Formosa Govt. Res. Inst. Dept. Agr. Rpt. $81: 39-40$.

TYPE-SPECIES : Diaulacaspis siamensis Takahashi, 1942, by original designation and monotypy.

The describer suggested a relation to Aulacaspis Cockerell but noted conspicuous differences.

Dichosoma Brimblecombe, 1957, Queensland Jour. Agr. Sci. 14: 271.

TXPE-SPECIES : Dichosoma convexa Brimblecombe, 1957, by original designation and monotypy.

The describer suggested a relationship to Neomorgania MacGillivray and Mimeraspis Brimblecombe in the Aspidiotini.

Diclavaspis Balachowsky, 1956, Mus. Roy. du Congo Belge [Tervuren] Ann: (n. s.) Sci. Zool. $3: 100$.

TYPE-SPECIES: Aspidiotus (Diaspidiotus) ehretiae Brain, 1918, by original designation.

The describer associated this genus closely with the aspidiotine genera Clavaspis MacGillivray, Quadraspidiotus MacGillivray, Abgrallaspis Balachowsky, and Aspidaspis Ferris.

Dicyphococcus Borchsenius, 1959, Ent. Obozr. 38: 165, 167.

TYPE-SPECIES : Dicyphococcus bigibbus Borchsenius, 1959, by original designation.

Its describer placed this genus close to Parafairmairia Cockerell and Cardiococcus Cockerell in the Coccidae (str.).

Didesmococcus Borchsenius, 1953, Ent. Obozr. 33: 281.

TYPE-SPECIES : Didesmococcus megriensis Borchsenius, 1953, by original designation.

Its describer placed this genus close to Sphaerolecanium Šulc in the Coccidae (str.).

Dimargarodes Silvestri, 1938, Notes d'Ent. Chinoise 5: 22.

TYPE-SPECIES : Margarodes mediterraneus Silvestri, 1908, by original designation and monotypy.

This genus belongs in the Margarodini where it can perhaps be distinguished from Margarodes Guilding (str.).

Dinaspidiotus Gómez-Menor, 1957, Eos 33 : 45.

A lapsus for Dynaspidiotus Thiem \& Gerneck.

Dinaspis Leonardi, 1911, Portici R. Scuola Super. di Agr. Lab. Zool. Gen.e Agr. Bol. 5 : 282.

TYPE-SPECIES : Dinaspis ichesii Leonardi, 1911, by subsequent designation of

Sasscer, 1912 : 95.

Recent workers have presented diverse opinions regarding this genus, but Ferris, 1938: $37,45-46$, considered it to be zoologically valid and Balachowsky, 1954e : 23, accepted it and assigned it to his Lepidosaphedina. 
Discoccus Ferris, 1955, Atlas of the Scale Insects of North America $7: 79$.

A lapsus for Discococcus Ferris.

Discococcus Ferris, 1953, Atlas of the Scale Insects of North America $6: 314$.

TYPE-SPECIES : Ehrhornia graminis Ferris, 1918, by original designation.

This genus was placed in the Pseudococcidae by its describer.

Discodiaspis Koronéos, 1934, Les Coccidae de la Grèce surtout du Pélion, p. 88.

TYPE-SPECIES : Discodiaspis suaedae Koronéos, 1934, by monotypy.

Lindinger, 1937: 183, and Balachowsky, 1953g: 749-750, placed the typespecies as a synonym of Protargionia salicorniae Gómez-Menor. Both Ferris, 1937d : 104, and Balachowsky, 1953g: 749-750, 754-755, considered the genus to be zoologically valid and assignable to the Odonaspidini.

Distichlicoccus Ferris, 1950, Atlas of the Scale Insects of North America (ser. 5) [v. 5]: 21, 48.

TYPE-SPECIES: Dactylopius salinus Cockerell, 1902, by original designation.

Its describer placed this genus in the Pseudococcidae.

Doriopus Brimblecombe, 1959, Queensland Jour. Agr. Sci. 16: 381, 397, nomen nudum; 1960, $17: 193$.

TYPE-SPECIES : Doriopus bilobus Brimblecombe, 1959, by original designation and monotypy.

Its describer associated this genus with the Australian diaspidid genera Hybridaspis Green and Hemiaspidis MacGillivray. Borchsenius and Williams, 1963, Brit. Mus. (Nat. Hist.) Ent. Bul. 13: 375, placed it in the Parlatoriini, noting that those affinities were revealed by the second-stage female.

Dorthesia d'Orthez (or Dorthez), 1785, Observations sur le Physique sur l'Histoire naturelle et sur les Arts [Jour. de Phys.] $26: 207$.

TYPE-SPECIES : Orthezia characias [Bosc d'Antic], 1784, by monotypy.

The original papers presenting this name and Orthezia Bose d'Antic have not been seen, and the conclusions here presented are based primarily on F. B. White, 1880: 304. According to him the originally presented generic name was Orthezia [Bosc] 1784; then, still according to White, the Abbé d'Orthez, whose name was the source of the original name, published on it in 1785 but emended Orthezia into Dorthesia. Both names have appeared in print subsequently as either "-zia" or "-sia." Signoret, 1868-1877, presented both Dorthesia and Dorthezia. This name, in either spelling, is currently accepted as belonging in synonymy under Orthezia Bosc d'Antic, 1784. The type-species is considered to be a synonym of Coccus urticae Linnaeus. 


\section{Douglariella MacGillivray, 1921, The Coccidae, p. 474.}

TYPE-SPECIES : Orthezia maenariensis Douglas, 1884, by substitution of this generic name for Douglasia MacGillivray, 1921, preoccupied.

MacGillivray replaced his Douglasia, preoccupied in the Lepidoptera and Coccoidea, with Douglariella. Laing, 1922: 254-255, synonymized the type-species with Orthezia urticae (Linnaeus), making Douglariella a synonym of Orthezia Bosc d' Antic.

\section{Douglasia Green, 1902, Victorian Nat. 19: 95 .}

TYPE-SPECIES : Coccus floccosus De Geer, 1778, by original designation and monotypy.

Green proposed this as a subgenus. It was preoccupied in Lepidoptera by Douglasia Stainton, 1854, according to Neave, 1939, Nomen. Zool. II : 151. In the same year, but probably about a month later, Green, Ent. Monthly Mag. 38: 285, published a practically identical paper, which proposed Newsteadia as the new subgeneric name, with " $D$. floccosus" as the type-species. We assume that editorial substitution was made for the preoccupied Douglasia since Green had forwarded both papers from Ceylon.

Douglasia MacGillivray, 1921, The Coccidae, pp. 110-111, 474.

TYPE-SPECIES: Orthezia maenariensis Douglas, 1884, by monotypy.

Laing, 1922: 254-255, showed that this name is a synonym of Orthezia urticae (Linnaeus). In this usage Douglasia is doubly preoccupied. See two preceding discussions.

Douglasiella MacGillivray, 1921, The Coccidae, p. 483.

A lapsus for Douglariella MacGillivray.

Drosicha Walker, 1858, List of the Specimens of Homopterous Insects in the Collection of the British Museum. Supplement, p. 306.

TYPE-SPECIES : Drosicha contrahens Walker, 1858, by monotypy.

This margarodid genus was reviewed by Morrison, 1928: 163.

Drosichiella Morrison, 1927, Biol. Soc. Wash. Proc. 40: 105.

TYPE-SPECIES : Monophlebus tamarindus Green, 1918, by original designation.

This genus is accepted as valid in Morrison, 1928: 160, but Rao, 1950a : 114, after examining the type specimens of tamarindus, reports that the genus name is a synonym of Perissopneumon Newstead, 1900.

Drosichoides Morrison, 1927, Biol. Soc. Wash. Proc. 40: 106.

TYPE-SPECIES : Llaveia haematoptera Cockerell, 1917, by original designation.

This genus was founded on the adult male only; its relationships to other margarodid genera were discussed by Morrison, 1928: 171.

Drosycha Signoret, 1875, Soc. Ent. de France Ann. (ser. 5) 5:351.

A lapsus for Drosicha Walker. 
Drymococcus Borchsenius, 1962, Akad. Nauk SSSR Zool. Inst. Trudy 30: [221].

TYPE-SPECIES : Drymococcus rhizophilus Borchsenius, 1962, by original designation and monotypy.

This genus was assigned by its describer to the Planococcini, Pseudococcidae, where it is considered close to Formicococcus Takahashi.

Dryocecis Amyot, 1847, Soc. Ent. de France Ann. (ser. 2) 5: 501.

This is a uninomial designation for a coccid species, Chermes variegata Olivier, which is currently assigned as a synonym of Kermes roboris (Fourcroy).

\section{Duplachionaspis MacGillivray, 1921, The Coccidae, p. 307.}

TYPE-SPECIES: Chionaspis graminis Green, 1896, by original designation.

MacGillivray included 21 species in this genus. Recent workers have accepted it as a zoologically valid unit. Balachowsky, 1954e: 171, assigned it to his Diaspidina, group II, chionaspiform.

Duplaspidiotus MacGillivray, 1921, The Coccidae, p. 394.

TYPE-SPECIES : Pseudaonidia clavigera Cockerell, 1901, by orginal designation.

The author placed this genus close to Pseudaonidia Cockerell. Ferris, 1937c: 51, 54, was doubtful of its distinctness, but later, 1938a : SII-252, accepted it as zoologically valid. Balachowsky, 1958b : 256-257, 268-269, accepted it and used it for species included in his study of African diaspidid coccids.

Duplaspis Goux, 1937, Soc. Ent. de France Bul. 42: 229.

TYPE-SPECIES: Duplaspis fraxini Goux, 1937, by original designation and monotypy.

Its describer placed this genus in the Diaspidini. Balachowsky, 1954e: 168, accepted it and placed it in his Diaspidina, group II, chionaspiform.

Dycryptaspis Cockerell, 1897, in Leonardi, Riv. di Patol. Veg. (Nov. 1896-Feb. 1897) 5: 375; 1897, U.S. Dept. Agr., Div. Ent., Tech. Ser. $6: 31$.

TYPE-SPECIES: Aspidiotus secretus Cockerell, 1896h: 20, by original designation and monotypy.

Leonardi discussed this name, crediting it to Cockerell and suppressing it as a synonym of his Odonaspis in a short published note in which he remarked on the details of a letter received from Cockerell after the publication of the Leonardi, 1897: 283-286, preliminary note on aspidiotine classification. Cockerell, in the reference cited, accepted Leonardi's suppression of his name in favor of Odonaspis, although without actual mention of Dycryptaspis. Lindinger, 1937: 184, 191 accepted Dycryptaspis Cockerell as valid nomenclatorially and as a replacement for Odonaspis Leonardi which he regarded as preoccupied by Odontaspis Agassiz, 1845. For further discussion on this problem, see Odonaspis Leonardi and Spatheaspis Leonardi. In spite of the emphasis Lindinger gave to this name, it does not seem to be included in Neave's Nomenclator Zoologicus. 
Dynaspidiotus Thiem and Gerneck, 1934, Arb. über Physiol. u. Angew. Ent. 1:131, 230-231.

TYPE-SPECIES: Aspidiotus britannicus Newstead, 1898, by original designation.

As a result of the unusual method used by these authors in presenting what seem to be extensive, critical, morphological studies, it is quite difficult to evaluate this genus properly. It was presented first (p. 131) as a subgenus, in the list of species studied. It appears to us to have been presented as both a nomenclatorial and a zoological unit much later in the paper (p. 231), where it was included in a key to the groups and species of Aspidiotini studied. The manner of presentation at this point “. . . Genus Dynaspidiotus (syn. Aspidiotus s. str.) (Typ: britannicus. Included hederae, abietis)" leaves no alternative to the conclusion that it is nomenclatorially a synonym of Aspidiotus Bouché. Acceptance of the existence of a zoologically independent unit, based initially on Aspidiotus britannicus Newstead, appears to date from Ferris, 1938a: SII-228, where he credited the genus to Thiem and Gerneck. Subsequent authors, including Balachowsky and Schmutterer, have followed this pattern, so the genus is now fairly well established in literature. It is our belief that the aspidiotine genera are much in need of critical classificatory studies, and that the zoological status of this unit must be considered as unsettled at present.

Dysmicoccus Ferris, 1950, Atlas of the Scale Insects of North America (ser. 5) [v. 5]: 22, 53.

TYPE-SPECIES : Dactylopius brevipes Cockerell, 1893, by original designation.

This genus was separated from Pseudococcus Westwood to care for a group of 13 species, most of which were assigned to Pseudococcus previously. On the basis of present knowledge of the species in this group, the separation can be maintained only on very narrow grounds.

Echinicerya Morrison, 1930, Biol. Soc. Wash. Proc. 43 : 17.

TYPE-SPECIES : Echinicerya anomala Morrison, 1930, by original designation and monotypy.

Its describer placed this genus in the Iceryini, Monophlebinae.

Echinococcus Balachowsky, 1936, Soc. Ent. de France Bul. 41: 157.

TYPE-SPECIES : Echinococcus echinatus Balachowsky, 1936, by original designation and monotypy.

This generic name was preoccupied by Echinococcus Rudolphi, 1801, in Vermes. Lindinger, 1943b: 219, recognized this prior usage and proposed the name Coccidohystrix as a replacement. Borchsenius, 1948a : 953; 1949:307, also noted the preoccupation and suggested the name Centrococcus. See the discussion under Centrococcus.

Edwalia Borchsenius, 1957, Akad. Nauk SSSR Zool. Inst. (n.s. 66) $9: 47$.

A lapsus for Edwallia Hempel. 
Edwallia Hempel, 1899, Canad. Ent. 31: 131.

TYPE-SPECIES : Edwallia rugosa Hempel, 1899, by original designation and monotypy.

This genus is placed in the group of "glassy" genera of Coccidae (str.).

Ehrhornia Ferris, 1918, Canad. Ent. 50:324-325.

TYPE-SPECIES : Sphaerococcus cupressi Ehrhorn, 1911, by original designation.

Ferris redescribed the type-species when he established the genus. Borchsenius, 1949: 87, 178, assigned it to the Pseudococcidae, as did Ferris, 1953a : 345, where he restricted the genus to the type-species and assigned the previously included $E$. graminis Ferris as type-species of a new genus, Discococcus.

Elatocecis Amyot, 1847, Soc. Ent. de France Ann. (ser. 2) 5: 502.

This is a uninomial designation presented to replace a generic and specific name for the insect involved. It is without nomenclatorial status.

Elizabetiella Borchsenius, 1947, Akad. Nauk Armians. SSR Dok. 7: 142; 1948, Akad. Nauk SSSR Dok. (n.s.) 61:953.

TYPE-SPECIES : Dactylopius nipae Maskell, 1893, by original designation and monotypy.

Borchsenius, 1948a : 953, placed this name as a synonym of Nipaecoccus Šulc.

Emmereziaspis Mamet, 1941, Mauritius Inst. Bul. $2: 36$.

TYPE-SPECIES : Fiorinia allaudi de Charmoy, 1899, by original designation [see U.S. Dept. Agr. Misc. Pub. 734: 89, under Grandpré and Charmoy].

The describer implied a relationship with Fiorinia Targioni-Tozzetti for this genus.

Encarsia Zoological Record, 1895, p. 364.

Kirkaldy, 1904a: 257, commented: "N.B. The genus Encarsia was listed under Coccidae in error in the Zool. Record for 1895." It is a hymenopterous genus.

Enlacaspis Cardin, 1915, Cuba Estac. Expt. Agron. Informe 3: 125.

A lapsus for Aulacaspis Cockerell.

Enlecanium Cockerell, 1929, Science $70: 150$.

A lapsus for Eulecanium Cockerell.

Entaspidiotus MacGillivray, 1921, The Coccidae, p. 394.

TYPE-SPECIES : Selenaspidus magnus Lindinger, 1909, by original designation.

Mamet, 1958a: 362, 413-414, accepted this aspidiotine genus as valid but restricted its coverage to two species rather than to the nine originally included by MacGillivray. 
Ephedraspis Borchsenius, 1949, Akad. Nauk SSSR Dok. (n.s.) 64: 738.

TYPE-SPECIES : Aspidiotus ephedrarum Lindinger, 1912, by original designation and monotypy.

Its proposer assigned this genus to the Aspidiotini and suggested a relationship to Chortinaspis Ferris. Balachowsky, 1956: 14, placed the name as a synonym of Abgrallaspis Balachowsky, 1948.

Epicoccus Cockerell, 1902, Ann. and Mag. Nat. Hist. (ser. 7) 9: 24. TYPE-SPECIES: Coccus acaciae Maskell, 1897, by original designation and monotypy.

This genus obviously assigns to the Pseudococcidae. Morrison and Morrison, $1922: 41$, redescribed the genus and its type-species, but since the redescription of Ripersia Signoret by Reyne, 1951a, their suggestions on probable relationships no longer have significance.

Epidiaspis Cockerell, 1899, Ill. Nat. Hist. Survey Bul. 5: 398; 1902, Entomologist 35 : 59 .

TYPE-SPECIES: (Aspidiotus piricola Del Guercio, 1894)=Diaspis leperii Signoret, 1869, by subsequent designation of Fernald, 1903b: 250.

The author presented this name in his checklist as a subgenus of Diaspis Costa with two included species, but in the second citation, associated the genus with piricola only. Lindinger, $1912 \mathrm{~b}: 359,388$, indicated the identity of species piricola Del Guercio, 1894, and leperii Signoret, 1869, by citing both as synonyms of betulae Baerensprung, 1849. Ferris, 1937: SI-51, and various European coccid students, including Balachowsky, 1954e:217, accepted the piricola-leperii synonymy but not Lindinger's opinion in regard to betulae. We have no critical opinion on this point. Balachowsky assigned the genus to the Diaspidina, group I, diaspiform.

Eremaspis Bodenheimer, 1951, Ent. Ber. $13: 330$.

TYPE-SPECIES : Pinnaspis zillae Hall, 1923, by original designation.

The describer indicated that this genus was proposed for certain species originally described in Pinnaspis Cockerell and Chionaspis Signoret. Borchsenius and Williams, 1963, Brit. Mus. (Nat. Hist.) Ent. Bul. 13: 360, placed it in synonymy with Contigaspis MacGillivray, 1921, because they considered the typespecies of the two genera congeneric.

Eremiaspis Balachowsky, 1951, Actualités Sci. et Indus., Ent. Appl. $1127: 671$.

TYPE-SPECIES : Hemiberlesia balachowskyi Rungs, 1936, by original designation and monotypy.

This name has priority of publication date over the preceding (before April as against Sept. 1), but even so, it seems to us that it will be possible to retain both names because of the one-letter difference in spelling (Code Article 56(a)). At the time of description, Balachowsky assigned this genus to his Aspidiotini, Targionina. 
Eremococcus Ferris, 1919, Canad. Ent. 51: 252.

TIPE-SPECIES: Sphaerococcus pirogallis Maskell, 1894, by original designation and monotypy.

The describer did not suggest any close relationships for this genus. Its typespecies was redescribed by Morrison and Morrison, 1922: 38, but their only suggestion was a possible relationship with Asterolecaniidae. Borchsenius, 1960d: \&S, agreed with this concept tentatively, suggesting that this genus may represent a third branch of that family.

Eremohallaspis Bodenheimer, 1951, Ent. Ber. 13:330.

TYPE-SPECIES : Coccomytilus farsetiae Hall, 1926, by original designation and monotypy.

Balachowsky, 1954e: 22, 26, 157-158, accepted this genus as zoologically valid and assigned it to his Lepidosaphedina.

Ericerus Guérin-Ménerille, 1858, Soc. Ent. de France Bul. (3) 6: Ixvii; Signoret, 1874, Soc. Ent. de France Ann. (5) 4: 90.

TYPE-SPECIES : Coccus ceriferus Fabricius [i.e. ceriferus of Anderson] as a misidentification by Guérin-Ménerille of Coccus pela Chavannes, 1848, by monotypy.

This name ras presented by Guérin-Ménerille as subgenus of Coccus Linnaeus, and with the single included species, which clearly was misidentified since he wrote of an insect which produces wax in China, while Fabricius referred to an Indian wax-producing insect. The original presentation by Guérin-Méneville did not seem to include any material that can be characterized as positively descriptire, or any indication that can gire substance to Guérin-Ménerille's presentation of the name for a ralid genus. Therefore it appears to have acquired nomenclatorial status only after its listing in Signoret's preliminary coccid catalog, 1869: 864, and solid zoological standing after Signoret presented his descriptire discussion of both genus and species, although Targioni-Tozzetti, 1866 : 140, did comment on this coccid briefly under the name "Pela cerifera nob." Regardless of any possible technicalities, this genus has stood as "Ericerus Guérin-Ménerille, 1858" for so many years (90 plus) that we believe it should be accepted as permanent in such association.

Eriocerus Cotes, 1891, Indian Mus. Notes 2 : 91.

A lapsus for Ericerus Guérin-Méneville.

Eriochitin MacGillirray, 1921, The Coccidae, pp. 168, 175.

A lapsus for Eriochiton Maskell.

Eriochiton Maskell, 1887, New Zeal. Inst. Trans. and Proc. (1886) 19 : 46.

TYPE-SFECIES: Eriochiton hispidus Maskell, 1887, by subsequent designation of Fernald, 1903b: 127.

Morrison and Morrison, 1922:63, redescribed this type-species and genus, and stated, incorrectly, that hispidus was the only species included in the genus by Maskell. The genus belongs in the Coccidae (str.), in the group of genera having the adult female enclosed in a felted test or sac. 
Eriococcus Targioni-Tozzetti, 1868, (separate) Soc. Ital. di Sci. Nat. Atti $11: 33 ; 1869,11: 726$.

TYPE-SPECIES : Coccus buxi Fonscolombe, 1834, by subsequent restriction of Signoret, $1872: 429$.

This is another early coccid genus with a tangled history. It was first proposed by Targioni-Tozzetti in 1868: 33, as "Gen. 9. Eriococcus nob." with five included species, all previously described in Coccus Linnaeus, but no type was selected or indicated. Signoret, 1870: 283, removed one of the five included species to a new genus of his own and in the process remarked that he was reserving Eriococcus "for $C$. festucae Fonsc." We do not regard this as type-species fixation in the face of the requirements of Article 67 (b) of the Code. A little later, Signoret, 1872: 422, 429, concluded that "Coccus buxi Fonscolombe is a true Coccite and for it we will retain the name of Eriococcus Targioni." This we accept as adequate type-species designation. Lindinger, 1933a: 77, discussed the status of Eriococcus at some length and pointed out, correctly we believe, that Fernald, 1903b: 70, should have designated Coccus buxi Fonscolombe as type-species of Eriococcus, rather than Coccus crispus Fonscolombe. Rather than accept this, however, Lindinger applied his own personal standard of selecting the first species included in any multispecific genus as its type-species. This approach led him to designate Coccus festucae Fonscolombe as the typespecies of Eriococcus, resulting in a very different zoological concept for the genus, and in his substitution of the name Nidularia Targioni-Tozzetti for the zoological concept of genus Eriococcus, as most coccid workers have accepted it.

Borchsenius, 1948: 501, reviewed this action by Lindinger and rejected the latter's type-species selection of Coccus festucae for Eriococcus. Borchsenius credited the genus to Signoret rather than to Targioni-Tozzetti on the ground that the latter's presentation was a nomen nudum. On this we disagree, believing that the Targioni-Tozzetti presentation constituted establishment through indication in accordance with the requirements of Article 16(a) (v) of the Code. As generally accepted zoologically, Eriococcus is a large genus containing numerous species described from many places in the world. Borchsenius, however, restricted the genus zoologically to the single type-species buxi on the ground that it alone possessed a certain specialized type of tubular duct, and transferred the majority of other described Eriococcus species to the genus Acanthococcus Signoret, 1875, which has long been regarded as a synonym of Eriococcus. We have examined specimens of buxi and have studied the specialized ducts on which his action is based. Our present view is that a critical morphological study of the whole eriococcine fauna of the world should be undertaken before wholesale transfer is accepted completely. Hoy, 1962: 29-30, and 1963, New Zeal. Dept. Sci. and Indus. Res. Bul. $150: 8$, reviewed the situation and rejected the Borchsenius actions, regarding both Acanthococcus Signoret and Rhizococcus Signoret as synonyms of Eriococcus Targioni-Tozzetti.

Eriodes Betrem, 1937, Arch. v. Koffiecult. Nederland Indië 11: 24, 99.

A lapsus for Erioides Green. This name, as spelled by Betrem, is preoccupied by Eriodes Geoffroy, 1829, in Mammalia.

Erioides Green, 1922, The Coccidae of Ceylon. Part V, p. 365.

TYPE-SPECIES : Erioides cuneiformis Green, 1922, by original designation.

This is a pseudococcid genus that has not been placed more precisely within that family. Lindinger, $1943 \mathrm{~b}: 219$, reviewed the nomenclatorial status of the name 
and concluded that it is derired from the same Greek source as Eriodes Geoffror, 1829 , and is so close to it that it must be rejected for use. He also noted that the trpe-species had appeared as Pipersia cuneiformis Green in the Cockerell, 1899a, Check List. Ferris, 1953a: 404, noting the similarity of life habit of Porococcus Cockerell and Erioides offered his opinion that Erioides was a srnonrm of the former. Te consider this doubtful. It has not been confirmed by any other worker.

Erioidococcus Lindinger, 1943, Ztschr. der Tien. Ent. Gesell. 28 : 219. TYPE-SPECIES: Erioides cuneiformis Green, 1922, by substitution of Erioidococcus for Erioides Green.

Lindinger substituted this name for Erioides Green. On the basis of the application of Article 56 (a) of the 1961 Code we consider this action unnecessary.

Eriopeltis Signoret, 18ז2, Soc. Ent. de France Ann. (ser. 5) 1: 429.

TYPE-SPECIES: Coccus festucae Fonscolombe, 1834, by original designation and monotypy.

The Fernald Catalogue, 1903b: 145, listed the type-species of this genus as Eriopeltis lichtensteinii Signoret, and under the citations to lichtensteinii cited as a preoccupied first reference "Eriopeltis festucae Sign. (non Fonsc.)" with page 430 of the reference giren abore as the place of publication. Subsequent type indications seem to hare followed this pattern. Te hare reriewed Signoret's rarious comments on genus and included species, and consider that the conclusion presented in Fernald is not correct, and that festucae Fonscolombe, as interpreted by Signoret, 1872, is the proper name for the type-species of Eriopeltis. In his first proposal of Eriopeltis, Signoret, 18 $72: 429-430$, remarked on the fact that the one species he was including forms a complete sac, "a mass of wool, so to speak, in the center of which is found the female ..." In a later presentation where lichtensteinii was discussed, Signoret, 1Si6: 607, said, "I hare alwass noted that there were two quite distinct trpes, one showing a sac of curled, woolly thread ... and the other, on the contrary, a very dense felted sac . . . I hare beliered that it would be well to make a new species of this latter type that we called Eriopeltis lichtensteinii, keeping the name festucae for the species trpical of Boyer de Fonscolombe, that we hare and that shows the curled woolly sac." Lindinger, 1933a: 77, argued at some length for the use of Eriococcus TargioniTozzetti for this Eriopeltis zoological concept but his proposal seems based on his rigid concept that the type-species of a multiple species genus must be the first one listed, so it can be disregarded. This genus is a member of the group of "woolly" genera belonging to the Coccidae (str.). Borchenius, 1957: 40, 91, placed it in his Filippiinae.

Erium (Cramford MS) Maskell, 1892, New Zeal. Inst. Trans. and Proc. (1891) 24: 35̆, nomen nudum; Cockerell, 1897, Amer. Nat. 31: 590 .

TYPE-SPECIES : Dactylopius globosus Maskell, 1592, by subsequent designation by Cockerell and monotypy.

This combination of generic and author names is offered in Neare, 1939, Nomen. Zool. II : 288. Fernald, 1903b: 112, credited the genus to Crawford and the trpe-species to Maskell. Maskell's recording of "Erium globosum," a manuscript name attached to specimens by Cratfford, following the description of Dactylopius globosus Maskell, makes Erium a nomen nudum under the negative restrictions of 
Article 11(d) of the 1961 Code, as actually, though perhaps not formally, publication in synonymy. The first affirmative action in giving generic type status to Erium was that taken by Cockerell, as cited, where he definitely considered it to be a subgenus of Dactylopius [i.e. Pseudococcus of current usage] and cited Dactylopius globosus Maskell [1892] as the type-species. We therefore believe that the genus should stand as Erium Cockerell, 1897, with type-species Dactylopius globosus Maskell, 1892, by subsequent designation and monotypy.

Morrison and Morrison, 1922: 48, redescribed the type-species, globosum, and noted the serious misunderstanding of the genus that had resulted from the Maskell distribution to coccid workers of specimens from other than the type lot. The genus as redefined from the type specimens was shown to be a characteristic pseudococeine form, differing from the genus Trionymus Berg, as then constituted, primarily in the possession of a rotund rather than an elongate, parallelsided body. A tentative synonymical association was suggested in this discussion but was not made positive. Lindinger, 1935a: 121, definitely recorded the synonymy of Trionymus with Erium and transferred a considerable number of species names to Erium. In his 1937 list of coccid genera, he placed 9 additional names as synonyms of Erium, an action resulting largely from his acceptance of Trionymus and its numerous synonyms as identical with Erium. One name so placed by him, Amonostherium Morrison (p. 179), is clearly an error, as its type was definitely stated to be a common North American species having little or no morphological relationship with true Dactylopius globosus Maskell. The classificatory status of this genus remains in question. It seems to have been pretty much overlooked by more recent students of the Pseudococcidae and its typespecies, globosum, is much in need of restudy to establish Erium in a proper relation to the flood of new pseudococcid genera that have been proposed in recent years.

Essigaspis MacGillivray, 1921, The Coccidae, p. 306.

TYPE-SPECIES: Protodiaspis agrifoliae Essig, 1914, by original designation and monotypy.

Ferris, 1936a: 21, 24, 26, and 1937: SI-99, placed this name as a synonym of Protodiaspis Cockerell.

Eucalymmatus Lindinger, 1943, Arb. über Morph. u. Taxonom. Ent. $10: 147$.

An emendation of Eucalymnatus Cockerell.

Eucalymnatus Cockerell, 1901, in Cockerell and Parrott, Canad. Ent. $33: 57$.

TYPE-SPECIES : Lecanium tessellatum Signoret, 1873, by original designation and monotypy.

Its proposer presented this as a subgenus of Lecanium Burmeister, but it stands as a genus in the Fernald Catalogue, 1903b: 165, and has been used constantly by coccid students since its proposal.

Eudinaspis Lizer, 1942, La Plata Univ. Nac. Inst. Mus. Notas 7 (Zool. $56): 76-78$.

TYPE-SPECIES : Eudinaspis jorgenseni Lizer, 1942, by monotypy.

Itg proposer placed this genus in the Diaspidini with a suggested close relationship to Dinaspis Leonardi. 
Eugreeniella Brimblecombe, 1958, Queensland Jour. Agr. Sci. 15: 87.

TYPE-SPECIEs: Aonidia (Greeniella) pulchra Green, 1905, by original designation and monotypy.

The describer noted resemblances to Greeniella Cockerell and Aonidia Targioni-Tozzetti in the Aspidiotini but concluded that the proper assignment of this genus was in the Diaspidini with relationships to Gymnaspis Newstead and Parlatoria Targioni-Tozzetti. Borchsenius and Williams, 1963, Brit. Mus. (Nat. Hist.) Ent. Bul. 13: 378, assigned it to the Parlatoriini, nearest to Agrophaspis Borchsenius and Williams, noting that its affinities were shown in the second-stage female.

Eulaingia Brimblecombe, 1958, Queensland Jour. Agr. Sci. 15: 80.

TYPE-SPECIES: Pseudaonidia stenophyllae Laing, 1929, b5 original designation and monotypy.

Its proposer suggested affinities with Pseudotargionia Lindinger and Neomorgania MacGillirras in the Aspidiotini. Borchsenius and Williams, 1963, Brit. Mus. (Nat. Hist.) Ent. Bul. 13: 384, confirmed its position in the Aspidiotini.

Eulecanium Cockerell, 1893, Amer. Ent. Soc. Trans. 20:54.

TYPE-SPECIES : Coccus tiliae Linnaeus, 1758 , by original designation.

Because of the enormous confusion that exists orer the proper assignment and synongmy of the many specific names that have been proposed in the Coccidae (str.), to which Eulecanium assigns, and perhaps because of some early cataloguing confusion, the treatment accorded this genus has been rariable. This name first appeared in print when Cockerell, 1893g: 54, presented it as a subgenus of Lecanium, "taking L. tiliae as the type." He stated that he was able to examine specimens of the 7 described species that he included in his "Third Series," and his specimens of tiliae are clearly defined by his presentation of adequate associated collection data. These particular specimens must be presumed to carry the burden of the zoological identity of the genus. However, they hare not been located. Therefore, we assume that the genus stands for a complex which first began to take shape in terms of modern recognition when Marchal, 1908: 295, redescribed and redefined Lecanium coryli (Linnaeus) and placed Coccus tiliae Linnaeus as a synonjm. Confusion over the probable identity of this trpe-species was compounded by the action of Šulc, 1932: 47, who used the name tiliae (Linnaeus) for the concept that Marchal called coryli and the name coryli (Linnaeus) for the concept that Marchal, 1908: 264, called corni (Bouché). Lindinger, 1937: 185, accepted Eulecanium as valid in his list of coccid generic names, dating it from 1896, and citing as type-species "E. accris $(\mathrm{Schr})=$. coryli $(\mathrm{L}$.)" because aceris was the first species included under Eulecanium by Cockerell, 1896b: 332, in his Check List.

The most recent broad treatment of this genus occurred in Borchsenius 1957: 381, 423. He accepted Eulecanium as ralid, but cited as its type-species, Coccus mali Schrank, 1is1, on the ground that Coccus coryli Linnaeus of authors has been anplied, through the sears, to sereral different species, and that the Linnaean name must be considered to be a nomen nudum because the original description is inadequate for acceptable recognition of the Linnaean species. Borchsenius dated the genus from 1596 and presented (p. 423) Coccus tiliae Linnacus as a definitely recognizable form distinct from other elements of the 
"coryli complex." Because of Cockerell's original positive action in 1893, we consider that the Borchsenius type designation is no more acceptable than was that of Lindinger in 1937. However, if Coccus tiliae Linnaeus is actually plainly recognizable today, as indicated by Borchsenius, there results no zoological dislocation of currently accepted understandings as he included it and coryli of authors in the same group of species. Various coccid workers from Sanders, 1909: 430, who retained the name "because it is impossible to eliminate Lecanium from our coccid nomenclature," through Šulc, 1932, to Kawecki, 19541961, have made use of the name Lecanium as a valid generic symbol for a particular group of species in the Coccidae (str.), usually with broader coverage than is implied by the name Eulecanium. While the Sanders statement is precisely correct, see Lecanium for a discussion of the status of the name as a zoologically valid nomenclatorial unit.

Eulepidosaphes Borchsenius and Williams, 1963, Brit. Mus. (Nat. Hist.) Ent. Bul. $13: 384$.

TYPE-SPECIES: Lepidosaphes marshalli Laing, 1925, by original designation and monotypy.

The authors placed this genus in the Diaspidini and noted differences from Lepidosaphes Shimer.

Euleucaspis Lindinger, 1905, Zool. Anz. 29: 252.

TYPE-SPECIES: (Leucaspis corsa Lindinger, 1905)=Leucaspis signoreti Targioni-Tozzetti, 1868, by monotypy.

This name was originally proposed for a "Sektion" of the genus Leucaspis. It was raised to the status of a subgenus by MacGillivray, 1921: 262, but with Coccus pini Hartig, invalidly nominated for type-species. Currently, Euleucaspis is accepted as a synonym of Leucaspis Targioni-Tozzetti, 1868, (or Leucodiaspis Signoret, 1869, according to Lindinger). See these names for further comment.

Eumargarodes Jakubski, 1950, Ann. and Mag. Nat. Hist. (ser. 12) 3: 397-399.

TYPE-SPECIES : Eumargarodes laingi Jakubski, 1950, by original designation and monotypy.

On present knowledge, this is a zoologically valid genus of the Margarodini.

Eumyrmecoccus Balachowsky, 1957, Rev. de Path. Veg. et d'Ent. Agr. de France $36: 158-159,162$.

A lapsus for Eumyrmococcus Silvestri.

Eumyrmococcus Silvestri, 1926, Portici R. Scuola Super. di Agr. Lab. Zool. Gen. e Agr. Bol. 18:271.

TYPE-SPECIES : Eumyrmococcus smithii Silvestri, 1926, by original designation and monotypy.

The describer associated this genus with Xenococcus Silvestri, 1924. It is an anomalous genus related to a few others reported from ant nests, of uncertain relationships but within the limits of the Dactylopiinae of the Fernald Catalogue, 1903b. 
Euparlatoria Leonardi, 1903, Portici R. Scuola Super. di Agr. Ann. (1904) (ser. 2) 5:15.

TYPE-SPECIES: (Parlatoria calianthina Berlese and Leonardi, 1895)= Parlatoria oleae Colvée, 1880, by subsequent designation of MacGillivray, 1921: 247.

The describer originally proposed this as a subgenus of Parlatoria. The name is regarded by current coccid workers as a synonym of Parlatoria Targioni-Tozzetti.

Euphilippia Berlese and Silvestri, 1906, Redia (1905) 3: 396.

TYPE-SPECIES : Euphilippia olivina Berlese and Silvestri, 1906, by monotypy.

Although the authors evidently considered that this form was distinct from Filippia [or Philippia] oleae (Costa), and some writers on the Mediterranean coccid fauna have so treated it, Lindinger, $1937: 185$, indicated that this genus is identical with Filippia Targioni-Tozzetti. Borchsenius, 1957: 188, 195, assigned both genus and species names to synonymy under Filippia oleae (Costa).

Eupulvinaria Borchsenius, 1953, Ent. Obozr. $33: 288$.

TYPE-SPECIES: Eupulvinaria peregrina Borchsenius, 1953, by original designation.

The describer placed this genus in his Pulvinariini, Coccinae, Coccidae (str.), and included 5 previously described species in addition to the type-species. A close relationship to Pulvinaria Targioni-Tozzetti was indicated.

Euraspidiotus Thiem and Gerneck, 1934, Arb. über Physiol. u. Angew. Ent. 1:131, 230-231.

TYPE-SPECIES : Aspidiotus ostreaeformis Curtis, 1843, by original designation.

The proposers of this unit presented it as a subgenus of Aspidiotus Bouché and included, in addition to the tspe-species, five related aspidiotine forms. The name is a synonym of Quadraspidiotus MacGillivray, 1921, by reason of community of type-species, and recent coccid workers have so accepted it.

Eurhizococcus Silvestri, 1936, Portici R. Ist. Super. di Agr. Lab. Zool. Gen. e Agr. Bol. 30 : 32-40.

TYPE-SPECIES : Margarodes brasiliensis Hempel, 1922, acc. to Silvestri ; Wille, 1922, acc. to Morrison; by original designation.

According to our understanding of Article 50 of the 1961 Code, it is necessary to credit the type-species, Margarodes brasiliensis, to Wille rather than to Hempel. Wille apparently furnished all the descriptive information included in the Egatea, 7: 83-85, article which first presented the species, although he credited Hempel with the specific name. This represents a ralid generic unit within the Margarodini, and currently includes one other species, brevicornis Silvestri, transferred from Termitococcus Silvestri.

Euripersia Borchsenius, 1948, Akad. Nauk SSSR Dok. (n.s.) 61: 955.

TYPE-SPECIES : Euripersia amnicola Borchsenius, 1948, by original designation and monotypy.

The describer, 1949: 179, incorporated this genus in the Pseudococcidae although he suggested that it was not too closely related to other genera of the 
family. Williams, 1962: 24, assigned to it two species from the British Isles, described in Ripersia Signoret by Newstead. We suspect that it has phenacoccine relationships.

Eurrhizococcus Lindinger, 1943, Ztschr. der Wien. Ent. Gesell. 28 : 219.

A lapsus for Eurhizococcus Silvestri.

Eurycerus Targioni-Tozzetti, 1867, Soc. Ital. di Sci. Nat. Mem. 3 (3) : 19,41 .

A lapsus for Ericerus Guérin-Méneville.

Eurycoccus Ferris, 1950, Atlas of the Scale Insects of North America (ser. 5) [v. 5]:22, 81 .

TYPE-SPECIES : Pseudococcus jessica Hollinger, 1916, by original designation.

The describer placed this genus in the Pseudococcioae with an implied relationship to Trionymus Berg.

Eutaxia Green, 1926, Bul. Ent. Res. 17 : 60.

TYPE-SPECIES: Eutaxia moreirae Green, 1926, by original designation and monotypy.

The describer placed this genus in the Coccidae (str.) without more precise assignment and there has been no recent restudy of the genus.

Euvoraspis Mamet, 1951, Inst. Sci. de Madagascar, Mém. Sér. A, 5 : 227.

TYPE-SPECIES : Chionaspis cordiae Mamet, 1936, by original designation and monotypy.

Its describer considered this genus allied to Voraspis Hall, 1946. Ferris, 1955d: 47, discussed the type-species in the course of a review of Phenacaspis Cooley and Cockerell and placed the name as a synonym of Phenacaspis.

Evallaspis Lupo, 1939, Portici R. Ist. Super. di Agri. Lab. Zool. Gen. e Agr. Bol. 31:130.

TYPE-SPECIES: Mytilaspis ampelodesmae Newstead, 1897, by original designation and monotypy.

The describer established this as a subgenus of "Mytilococcus" [Lepidosaphes auct.]. Balachowsky, 1954e: 21-23, 27, 147-148, 154, accepted it as an aberrant genus in his Lepidosaphedina.

Evaspidiotus Leonardi, 1898, Riv. di Patol. Veg. (1897) 6: 50(210), $74(232)$.

TYPE-SPECTES : Chermes hederae Vallot [?], by original designation.

The author presented this as a subgenus of Aspidiotus Bouché. The name is a synonym of Aspidiotus from community of type-species. See Aspidiotus for a discussion of the status of the name Chermes hederae Vallot. 
Exaeretopus Newstead, 1894, Ent. Monthly Mag. 30 : 204.

TYPE SPECIES : Exaeretopus formiceticola Newstead, 1894, by monotypy.

According to Lindinger, $1937: 185$, and $1943 \mathrm{~b}: 221$, this name is a synonym of "Lecaniopsis" Targioni-Tozzetti, 1868. Borchsenius, 1957: 116, treated it as a valid genus which he associated with Lecanopsis Targioni-Tozzetti and Luzulaspis Cockerell in his Filippiinae, Coccidae (str.).

Exeraetopus Bodenheimer, 1928, Konowia 7 : 192.

A lapsus for Exaeretopus Newstead.

Exilipedronia Williams, 1960, Brit. Mus. (Nat. Hist.) Bul. Ent. 8: 397.

TYPE-SPECIES : Exilipedronia sutana Williams, 1960, by original designation and monotypy.

The describer placed this genus in the Pseudococcidae with a suggested closest relationship to Pedronia Green and Pedrococcus Mamet.

Exoerctopus Cockerell, 1894, Amer. Nat. $28: 1051$.

A lapsus for Exaeretopus Newstead.

Exoeretopus Cockerell, 1896, Ill. State Lab. Nat. Hist. 4: 333.

A lapsus for Exaeretopus Newstead.

Exuviaspis Ferris, 1941, Atlas of the Scale Insects of North America (ser. 3) [v.3]: SIII-285.

TYPE-SPECIES : Exuviaspis enceliae Ferris, 1941, by original designation and monotypy.

Although the describer included this genus in the Diaspidini, he emphasized his inability to suggest any closer relationships for it. There has been no restudy of the type-species since the original presentation.

Fagisuga Lindinger, 1909, Ztschr. f. Wiss. Insektenbiol. 5 : 107.

TYPE-SPECIES : Fagisuga triloba Lindinger, 1909, by monotypy.

This genus was assigned to the Conchaspididae, but Mamet, 1954b : 193, in his monograph of this group, concluded that Balachowsky, 1948b : 257, was correct in placing it in the Phoenicococcidae.

Fairmairea Lindinger, 1907, Ent. Wochenblatt 24:20.

An emendation of Fairmairia Signoret.

Fairmairia Signoret, 1872, Soc. Ent. de France Ann. (Bul. Ent.) (ser. 5) 2: xxxvi; 1874, Soc. Ent. de France Ann. (ser. 5) 4:98; 1875, Soc. Ent. de France Ann. (Bul. Ent.) (1874) (ser. 5) 4: vii.

TYPE-SPECIES : Fairmairia bipartita Signoret, 1872, by monotypy.

Signoret first presented this generic name in 1872, as cited, at which point he described the gross appearance of the insect to an extent sufficient, in our view, to validate the names under Article 16 of the 1961 Code. The generic name 
Fairmairia was noted to be preoccupied by use in the Diptera, and Cockerell, 1899m : 332, replaced it in Coccoidea with Parafairmairia.

Farinococcus Morrison, 1922, Psyche 29 : 137.

TYPE-SPECIES : Farinococcus multispinosus Morrison, 1922, by original designation and monotypy.

Originally placed merely as belonging in the Pseudococcidae, this genus has been shown by more recent studies (Ferris, 1955:2) to be a member of a group of mealybug genera provided with an abundance of marginal cerarian spines, present either in dense clusters or running continuously along the body margin.

Farrmairia Hempel, 1899, Canad. Ent. 31:131.

A lapsus for Fairmairia Signoret.

Fasisuga Brues and Melander, 1932, Mus. Comp. Zool. Harvard Bul. $73: 131$.

A lapsus for Fagisuga Lindinger.

Fernaldanna MacGillivray, 1921, The Coccidae, p. 276.

TYPE-SPECIES : Mytilaspis indentata Green, 1900, by substitution of Fernal danna for Fernaldella Leonardi.

This name was proposed as a replacement for Fernaldella Leonardi, 1903, preoccupied in Lepidoptera. Ferris, 1937a: 4, considered the unit zoologically valid. Balachowsky, 1954e : 23, accepted it, and placed it in his Lepidosaphedina.

Fernaldella Leonardi, 1903, Portici R. Scuola Super. di Agr. Ann. (1904) (ser. 2) 5:105-106,109, 111.

TYPE-SPECIES : Mytilaspis indentata Green, 1900, by monotypy.

This name was replaced by Fernaldanna MacGillivray, 1921, on account of preoccupation in the Lepidoptera, a fact noted by Sanders, 1909a: 58.

Fernaldiella Leonardi, 1903, Portici R. Scuola Super. di Agr. Ann. (1904) (ser. 2) 5:4, 112 .

Leonardi presented this spelling in his generic key; all (4) subsequent references in his paper were to Fernaldella. Sanders, $1906: 16$, first accepted Fernaldiella for the Leonardi genus and then, 1909a: 58, modified it to the preoccupied Fernaldella. This "first reviser" action seems to us to dispose permanently of this name.

Ferrisaspis MacGillivray, 1921, The Coccidae, p. 388.

TYPE-SPECIES : Aspidiotus covilleae Ferris, 1919, by original designation and monotypy.

Ferris, 1937c: 51, 54, regarded this genus as not separable from Diaspidiotus Berlese and Leonardi. Later he, 1938a: SII-202, definitely placed the name as a synonym of Clavaspis MacGillivray. 
Ferrisia Fullamay, 1923, Hamaii. Ent. Soc. Proc. 5: 309, 311.

TYPE-SPECIES: Dactylopius virgatus Cockerell, 1S93, b5 original designation and monotypy.

This is currently accepted as a ralid zoological unit in the Pseudococcidae.

Ferrisiana Takahashi, 1929, Formosa Nat. Hist. Soc. Trans. 19: 429.

Takahashi proposed this name to replace Ferrisia Fullarras on the grounds that the latter was preoccupied br Ferrissia Walker, 1903 (IIollusca). This usage had some currencs for a time, but the change was unjustified, in our opinion, on the basis of earlier Code rules, and the 1961 Code in Article 56 (a) forbids a change of generic name if there is so much as one letter difference, which applied in this instance.

Ferrisiaspis Balachowsky, 1956, Mus. Roy. du Congo Belge [Terruren] Ann. (n.s.) Sci. Zool. 3:90.

A lapsus for Ferrisaspis MacGillivray.

Ferrisicoccus Ezzat and McConnell, 1956, MId. Agr. Expt. Sta. Bull. A-84: 13, 31.

TYPE-SPECIEs : Ferrisicoccus angustus Ezzat and IIcConnell, 1956, by original designation.

The describers assigned this genus to the Planococcini, Pseudococcidae.

Ferrisidiaspis Bodenheimer, 1951, Ent. Ber. 13 : 329 .

TYPE-sPECIES : Diaspis syriaca Lindinger, 1912, by original designation and monotypy.

Balachowsky, 1954e: 173, placed this name as a șnonrm of Diaspis Costa.

Filippia Targioni-Tozzetti, 1868, (separate) Soc. Ital. di Sci. Nat. Atti $11: 33 ; 1869,11: 726$.

TYPE-SPECIES: Phitippia follicularis Targioni-Tozzetti. 1867, [Coccus oleae A. Costa, 1857, partim (non O. G. Costa, 1828) ], by substitution of Filippia for Philippia and present designation.

Targioni-Tozzetti first presented this zoological unit in $186 \pi$ as Philippia. He change the spelling to Filippia in 1868: 33, without ans explanation and in so doing escaped the priority problem set up by Philippia Gras, 1Sti (Mollusca). It has been customary among coccid cataloguers and other workers to credit the trpe-species of this genus to O. G. Costa, 1528. Howerer. Targioni-Tozzetti was specific in designating certain figures in a plate published in 1557 by $\mathrm{A}$. Costa as the basis for his genus, and for Targioni-Tozzetti's follicularis. We have studied the descriptire material presented by O. G. Costa, 1S2S, and conclude that it contains onls a presentation of the coccid species currently called saissetia cleae (Bernard) and that there is no certain evidence that it contains ans material that suggests the trpe-species of Fitippia. We hare also reriewed material rresented by $\mathrm{A}$. Costa. 15.57, under the designation Coccus oleae, and consider that it, ton. relates primarily to the saissetia olcae of current understanding. We therefore conclude that it is best to designate the trpe-species of Filippia as $F$. follicularis (Targioni-Tozzetti), 186i. A. Costa, 187 7 , in the rerised edition 
of his 1857 paper, expressed similar conclusions respecting the material discussed in O. G. Costa, 1828, and A. Costa, 1857.

Finaspis Hall, 1946, Roy. Ent. Soc., London, Trans. $97: 517$.

TYPE-SPECIES : Lepidosaphes distincta Hall, 1929, by original designation and monotypy.

The author described this genus in the Diaspidini, noting some affinities with Africaspis MacGillivray. He rejected the Lindinger, 1932f: 202, assignment of the type-species to Pygalataspis Ferris.

Fiorina, Signoret, 1869, Soc. Ent. de France Ann. (ser. 4) 8: 845.

Signoret presented this name in his catalog of previously described species as "Fiorina?" in connection with his preliminary assignment of Coccus buxi Fonscolombe. We presume, since he used Fiorinia elsewhere in his monograph, that this is a lapsus.

Fiorinia Targioni-Tozzetti, 1868, (separate) Soc. Ital. di Sci. Nat., Atti 11: 42; 1869, 11: 735 .

TYPE-SPECIES : (Fiorinia pellucida Targioni-Tozzetti, 1868)=Diaspis fioriniae Targioni-Tozzetti, 1867, by monotypy.

This generic name has been accepted consistently by coccid workers since its proposal. Numerous species are now included. Balachowsky, 1954e : 322, placed the genus in Diaspidini, Diaspidina, group II, chionaspiform.

Fisanotargionia Kaussari and Balachowsky, 1953, Rev. de Path. Veg. et d'Ent. Agr. de France 32: 277.

TYPE-SPECIES : Fisanotargionia quadrilobata Kaussari and Balachowsky, 1953, by original designation and monotypy.

The describers placed this genus in Aspidiotini, Targionina of the Balachowsky classification system, with an indicated relationship to Targionia signoret.

Fissiventer Misra, 1924, Ent. Mtg. (Pusa, 1923) Proc. 5 : 346.

TYPE-SPECIES: Walkeriana polei Green, 1896, by original designation.

This was listed as a subgenus of Walkeriana Signoret. Since polei Green is the type-species of Labioproctus Green, 1922, Fissiventer is a synonym of the older name.

Fissuraspis Ferris, 1937, Atlas of the Scale Insects of North America (ser.1) [v. 1]:SI-56.

TYPE-SPECIES : Crypthemichionaspis ulmi Hoke, 1927, by original designation and monotypy.

The proposer placed this genus in the Diaspidini with no more precise suggestions as to its relationships. Balachowsky and Kaussari, 1951: 7, discussed its relation to certain other genera and compared it with Salicicola davatchi, new species. Lindinger, 1957: 544, assigned the type-species to Anamefiorinia Leonardi.

Fonscolombea Lindinger, 1908, Berlin. Ent. Ztschr. (1907) 52: 94.

An emendation of Fonscolombia Lichtenstein. 
Fonscolombia Lichtenstein, 1877, Soc. Ent. de France Ann. (Bul. Ent.) (ser. 5) 7:cviii.

TYPE-SPECIES : Fonscolombia graminis Lichtenstein, 1877 (which he believed to be identical with Coccus radicumgraminis Fonscolombe), by original designation and monotypy.

This is another coccoid genus with a most uncertain background and current status. Aside from the fact that most coccid workers who have mentioned the genus believe that Coccus radicumgraminis Fonscolombe, 1834, generally cited as the type-species, is not today recognizable with certainty, it seems clear to us that the genus, in any zoological sense, must be based on the specimens which Lichtenstein examined and discussed, and which he chose to call Fonscolombia graminis. We do not know if these specimens exist, or their location if still intact. As he based the genus on wingless adult males with secreted caudal filaments, a secondary complication to satisfactory placement results. No adequate scheme of coccid classification based on adult males exists today. The status of the genus has been further complicated by the introduction into it of Chermes fraxini Kaltenbach, a coccid species having a quite different habitus than does the type-species. As a result, the Fernald Catalogue, 1903b: 114, for example, placed both Apterococcus Newstead, 1898, and Pseudochermes Nitsche, 1895, as synonyms, but, we believe, wholly without warrant in the existing circumstances.

Assignments of the genus have been to the Dactylopiidae or Eriococcidae by Ferris, 1957c: 86, and to the Coccidae (str.) by Lindinger, 1943b: 221, as a synonym of Lecanopsis Targioni-Tozzetti, 1868. With respect to this last assignment, complications again are present. Borchsenius, 1957: 191, said that males are not known for Lecanopsis. An interesting sidelight on this problem is found in the lot number book of Mrs. Anna Botsford Comstock, which we have examined. Under lot 235, Sub 1, is listed a preparation of "Lecanopsis rhizophila ??" received 8 May 1882 from J. Lichtenstein. The specimen involved under this name has been examined and, although a very poor preparation on present-day standards, shows that it is a root-feeding pseudococcid having some, at least, of the characteristics of the genus Cryptoripersia Cockerell as this genus is currently accepted in the United States. The notebook entry also includes this note, evidently a comment by Lichtenstein, in lit.: "Fonscolombia is a synonym of Lecanopsis Targioni, yet it is under observation as I have two males (one winged and one apterous) and only one female, so I keep it in reserve until I get the whole cycle of life?" From this we conclude that the Lichtenstein concept of Fonscolombia and Lecanopsis actually was pseudococcid. Hoy, 1963, New Zeal. Dept. Sci. and Indus. Res. Bul. 150: 9, included Fonscolombia in the Eriococcidae on the basis that species previously referred to this genus are known to belong in that family.

It is our present conclusion first, that this generic name is nomenclatorially valid and is available when it can be associated critically with some coccid unit; second, that the concepts of its zoological identity which have been presented by the more recent coccid workers have not emerged with sufficient consistency or clarity to justify arbitrary proposals for its classificatory assignment; third, that the association and characteristics implied by its assignment in the Fernald Catalogue, 1903b: 114, must be regarded with a question because they actually are based primarily on a second, well-known species that was assigned arbitrarily to this genus. 
Forbesaspis MacGillivray, 1921, The Coccidae, p. 388.

TYPE-SPECIES : Aspidiotus forbesi Johnston, 1896, by original designation and monotypy.

Ferris, 1938a: SII-255, placed this name as a synonym of Quadraspidiotus MacGillivray, and Balachowsky, 1950b : 397 ; 1958b : 210, agreed with his action.

Formicicoccus Lindinger, 1932, Konowia 11:197.

An emendation of Formicococcus Takahashi. Lindinger, 1937: 185, used the original spelling, not the emendation, in his generic list.

Formicococcus Takahashi, 1928, Formosa Nat. Hist. Soc. Trans. 18:

253.

TYPE-SPECIES : Formicococcus cinnamomi Takahashi, 1928, by original designation and monotypy.

This genus belongs to the Pseudococcidae and was treated in some detail in relation to related genera by Ezzat and McConnell, 1956 : 35-37, who included it in their Planococcini.

Formicoccus Schmutterer, 1957, in Sorauer, Handb. der Pflanzenkrankheiten V (pt.2) : 440.

A lapsus for Formicococcus Takahashi.

Formosaspis Takahashi, 1932, Soc. Trop. Agr. Jour. 4:47.

TYPE-SPECIES : Protodiaspis nigra Takahashi, 1930, by original designation.

The describer implied some relationship to Chionaspis Signoret and Leucaspis Targioni-Tozzetti in presenting this genus. Lindinger, 1937:185, said "=Anamefiorinia Leonardi." Ferris, 1937d: 104, accepted it as probably valid.

Freenchia Balachowsky, 1937, Actualités Sci. et Indus., Ent. Appl. $526: 49$.

A lapsus for Frenchia Maskell.

Frenchia Maskell, 1892, New Zeal. Inst. Trans. and Proc. (1891) 24: 56.

TYPE-SPECIES : Frenchia casuarinae Maskell, 1892, by monotypy.

This genus actually belongs in the Asterolecaniidae. See Morrison and Morrison, $1922: 17-20$, for a redescription of the type-species.

Frogatiella Balachowsky, 1953, Actualités Sci. et Indus., Ent. Appl. $1202: 727$.

A lapsus for Froggattiella Leonardi.

Froggattiella Leonardi, 1900, in Cockerell, Psyche 9 : 72 (rec'd USDA Lib. VI-1-1900) ; 1900, Riv. de Patol. Veg. 8: 299-300 (publ. VIII31-1900).

TYPE-SPECIES : Aspidiotus inusitatus Green, 1896, by monotypy.

Ferris, 1937a : 33, accepted this as a probably valid genus, and placed it in his Odonaspidini. Balachowsky, 1953g: 727 , accepted it in the same way. 
Fulaspis Balachomsky, 1952, Rev. de Path. Veg. et d'Ent. Agr. de France 31: 121.

TYPE-SPECIES : Fulaspis guilliermi Balachowsky, 1952, bJ original designation and monotypy.

The describer placed this genus in Diaspidinae, Diaspidini, Lepidosaphedina of his system of classification, and in his synoptic work, 1954: 142-143, confirmed the assignment.

Fulbrightia Ferris, 1950, Microentomology 15 : 7.

TYPE-SPECIES: Fulbrightia gallicola Ferris, by original designation and monotypy.

The describer placed this genus in the Eriococcidae as characterized by him. Hoy, 1963, New Zeal. Dept. Sci. and Indus. Res. Bul. 150:9, confirmed this assignment.

Fundaspis MacGillivray, 1921, The Coccidae, p. 307.

TYPE-SPECIES : Chionaspis americana Johnson, 1896, by original designation.

Ferris, 1936a : 21, 24, and Balachowsky, 1954e : 317, placed this name as a synonym of Chionaspis Signoret. Lindinger, $1937: 185$, accepted it as a valid genus.

Fuparlatoria Leonardi, 1903, Portici R. Scuola Super. di Agr. Ann. (1904) (ser.2) 5:15.

A lapsus for Euparlatoria Leonardi.

Furcadaspis Lupo, 1938, Portici R. Ist. Super. di Agr. Lab. Zool. Gen. e Agr. Bol. 30 : 255.

A lapsus for Furchadaspis MacGillivray.

Furcaspis Lindinger, 1908, Berlin. Ent. Ztschr. (1907) 52: 98-99.

TYPE-SPECIES : Aspidiotus biformis Cockerell, 1893, by subsequent designation of Sanders, 1909a : 54 .

This is a zoologically valid genus which Lindinger, $1910: 156,330$, placed in his Parlatoreae group. It has been associated more often with the aspidiotine series of genera by other authors; e.g., Ferris, 1942: SIV-446(33). Lindinger, 1937: 185, placed as synonyms: Neofurcaspis Green, Paraonidiella MacGillirray, Separaspis MacGillivray, Stringaspidiotus MacGillivray, and Truncaspidiotus MacGillivray.

Furchadaspis MacGillivray, 1921, The Coccidae, p. 310.

TYPE-SPECIES: Diaspis zamiae Morgan, 1890, by original designation and monotypy.

This is generally accepted as a valid zoological unit by coccid students. Balachowsky, 1954e: 212, placed the genus in his Diaspidina, diaspiform.

Furchadiaspis Ferris, 1936, Microentomology $1: 21,24$.

So far as can be determined this was a lapsus for Fuchadaspis MacGillivray and unfortunately was followed by some other coccid workers who relied on 
Ferris rather than on the original presentation. Neave, 1950, Nomen. Zool. V : 100, charged the misspelling to Hall, $1941: 230$, but the Ferris usage came earlier.

Furchaspis Ferris, 1938, Microentomology $3: 46$.

This spelling appeared in a list of generic names ending in "aspis" which Ferris compiled and published. From the fact that Furcaspis Lindinger is not included in the list, we presume that Furchaspis is a lapsus for it.

Furoaspis Lindinger, 1937, Ent. Jahrb. 46 : 197.

A lapsus for Furcaspis Lindinger.

Fusilaspis MacGillivray, 1921, The Coccidae, p. 275.

TYPE-SPECIES : Mytilaspis phymatodidis Maskell, 1880, by original designation.

There seems to have been no modern restudy of this genus. Lindinger, 1937 : 185, said, "=Polyaspis Mask." (i.e., Poliaspis), but there is no reason to suppose that this is a critical opinion resting on a study of the type-species.

Gadaspis Hall, 1946, Roy. Ent. Soc., London, Trans. 97 : 509, 518.

TYPE-SPECIES: Chionaspis (Pinnaspis) combreti Hall, 1928, by original designation.

The describer related this genus to Pinnaspis Cockerell and Contigaspis MacGillivray. Balachowsky, 1954e: 172, placed it in his Diaspidina, group II, chionaspiform.

Galeraspis Mamet, 1939, Roy. Ent. Soc., London, Trans. $89: 589$.

TYPE-SPECIES : Galeraspis eugeniae Mamet, 1939, by original designation and monotypy.

Its describer offered no suggestions for the proper association of this genus, nor did Ferris, 1941a: 12, 17, who accepted it as valid and reillustrated it. As of now, the genus places as an aberrant diaspidine form.

Gallipalpus Signoret, 1869, Soc. Ent. de France Ann. (1868) (ser. 4) $8: 832$.

A lapsus for Callipappus Guérin-Méneville.

Gallipappus Signoret, 1868, Soc. Ent. de France Ann. (ser. 4) 8:519520,$526 ; 1869$ (ser.4) 9:103.

A lapsus for Callipappus Guérin-Méneville.

Gascardia Targioni-Tozzetti, 1893, in A. Gascard, Contribution a l'étude des gommes lacques des Indes \& Madagascar, pp. 73, 88, 121.

TYPE-SPECIES: Gascardia madagascariensis Targioni-Tozzetti, 1893, by monotypy.

This genus is obviously a close relative of Ceroplastes Gray in the Coccidae (str.) and is similar in growth habit to Cockerell's subgenus Ceroplastidia. Mamet, 1951: 216, considered it a valid genus closely related to Ceroplastes and not belonging in the Lacciferidae. 
Gassyparia Balachowsky, 1927, Soc. Ent. de France Ann. $96: 189$.

A lapsus for Gossyparia Signoret.

Gasteralphe Icery, 1864, Mem. sur le pou à poche blanche, 8 p. (not seen) ; 1864 (or 1865), Ent. Soc. London, Trans. (ser. 3) 2: 55 (translation).

This name is included in Neave, 1940, Nomen. Zool. IV sup.: 736, but the reason for the inclusion is not evident. We have not seen the original Icery pamphlet, but the translated presentation cited above appears to offer this name only as a uninomial designation similar to those of Amyot, 1847, and so is without nomenclatorial standing. The insect involved is now considered to be properly called Pulvinaria iceryi (Signoret). See Mamet, 1958:66-69, for detailed discussion.

Gasteralphes Guérin-Méneville, 1868, Rev. et Mag. de Zool. (ser. 2) $20: 127$.

This author listed Gasteralphes iceryi Signoret as "The Gasteralphe of Icery." Mamet, 1958: 69, considered the Guérin-Méneville elevation of Gasteralphes to generic rank without standing in nomenclature. See Mamet for details.

Gasteralphus Guérin-Méneville, 1868, Soc. Imp. et Cent. d'Agr. de France, Bul. de Séances (ser. 3) 3:248.

An emendation of Gasteralphes Guérin-Méneville.

Genaparlatoria MacGillivray, 1921, The Coccidae, p. 248.

TYPE-SPECIES: Parlatoria pseudaspidiotus Lindinger, 1905, by original designation.

This genus has been accepted as zoologically valid by recent coccid students. Balachowsky, 1958b: 318, placed it in his Parlatorini, Parlatorina of the Diaspidinae.

Genistaspis Bodenheimer, 1949, The Coccoidea of Turkey, Ankara, Güney (Pub. Office No. 670) : 26, 38, 83 (in Turkish); 1951, Ent. Ber. 13: 329 (in English).

TYPE-SPECIES : Genistaspis zelihiae Bodenheimer, 1949, by original designation and monotypy.

The describer placed this genus as close to Targionia Signoret, which was assigned by Balachowsky, 1951: 632, to his Targionina, Aspidiotini, Aspidiotinae.

Geococcus Green, 1902, Ent. Monthly Mag. 38: 262.

TYPE-SPECIES: Geococcus radicum Green, 1902, by original designation and monotypy.

Hambleton, 1946: 10, 12, associated this genus with an unnamed group of genera in the Pseudococcidae centering on Rhizoecus Künckel d'Herculais. 
Getulaspis Balachowsky, 1954, Inst. Pasteur [Paris] Mém. Sci., pp. 171,365 .

TYPE-SPECIES : Chionaspis (Phenacaspis) bupleuri Marchal, 1904, by original designation and monotypy.

The describer placed this genus in his Diaspidina, group II, chionaspiform, and noted that it had all of the general characters of Voraspis Hall.

Giganticoccus van der Goot, 1917, Proefsta. Midden-Java, Salatiga, Meded. No. 25: 31, nomen nudum. This name was presented as "Giganticoccus degueliae mihi i.1."

Globulicoccus Lindinger, 1907, Ent. Bl. $3: 138$.

TYPE-SPECIES: "L[ecanium] (Globulicoccus subg. n) fuscum (Gmel.) Dougl.," 1789, by original indication.

Although the type indication above does not conform to the 1961 Code rules covering type-species of genera (Art. 66-70), the assignment appears inevitable from Lindinger's manner of presentation. Lindinger, $1937: 186$, placed the name as a synonym of Eulecanium Cockerell, and Borchsenius, 1957 : 386, did likewise.

Gomezmenoraspis Balachowsky, 1953, Actualités Sci. et Indus., Ent. Appl. 1202: 907.

TYPE-SPECIES : Aonidia pinicola Leonardi, 1906, by original designation and monotypy.

Balachowsky placed this genus in his Parlatorini, Leucaspidina, Diaspididae.

Gomphaspidiotus Borchsenius and Williams, 1963, Brit. Mus. (Nat. Hist.) Ent. Bul. $13: 384,389$.

TYPE-SPECIES: Aspidiotus cuculus Green, 1905, by original designation and monotypy.

The authors placed this genus in the Pseudaonidia group of genera of the Aspidiotini. They considered it closest to Neomorgania MacGillivray, Diastolaspis Brimblecombe, and Dichosoma Brimblecombe.

Gonaspidiotus MacGillivray, 1921, The Coccidae, p. 390.

TYPE-SPECIES: Aspidiotus minimus Leonardi, 1896, by original designation.

Balachowsky, 1950 : 535, 545, accepted this as a zoologically valid unit and included it in his group of aspidiotine genera.

Gossiparia Chorbadzhiev, 1939, Izv. B'lgarsk. Ent. Druzh. for 1938, Sofia, 10: 89 .

A lapsus for Gossyparia Signoret.

Gossyparia Signoret, 1875, Soc. Ent. de France Ann. (Bul. Ent.) (ser. 5) 4: ccxx; 1875, Soc. Ent. de France Ann. (ser. 5) 5: 16, 20. TYPE-SPECIES : Coccus ulmi Geoffroy (non binomial) of Signoret, 1875, currently Coccus spurius Modeer, 1778, by subsequent designation of the describer.

Zoologically this genus is currently placed in the Eriococcidae. Ferris, 1957c: 85, made the name a synonym of Eriococcus, but Hoy, 1963, New Zeal. Dept. Sci. 
and Indus. Res. Bul. 150: 9, considered the genus valid. Other workers considered it zoologically valid and assigned it within a comparable complex, either of family status or as a recognizable group of genera within the Pseudococcidae (Borchsenius, 1949: 9, 327). We believe that its final zoological status will be determined only when there has been a thorough taxonomic study of all the species which group with it.

Gossyperia Kuwana, 1907 [Japan] Imp. Cent. Agr. Expt. Sta. Bul. $1(2): 213$.

A lapsus for Gossyparia Signoret.

Gossypariella Borchsenius, 1960, Ent. Obozr. 39 : 920.

TYPE-SPECIES : Rhizococcus siamensis Takahashi, 1942, by original designation and monotypy.

Borchsenius placed this genus close to Gossyparia Signoret in the Eriococcidae. It was so accepted by Hoy, 1963, New Zeal. Dept. Sci. and Indus. Res. Bul. $150: 9$, on the basis of the description and figure presented by Borchsenius.

Gramenaspis MacGillivray, 1921, The Coccidae, p. 309.

TYPE-SPECIES : Chionaspis africana Newstead, 1912, by original designation and monotypy.

Hall, 1946: 519, commented that while neither type nor any slides or material of the type-species have been found, the characters giren by Newstead suggest the validity of the genus.

Graminococcus Kiritschenko, 1940, Rpt. Odessa Univ. Bion. Ser. 4: 187 (not seen); Borchsenius, 1949, Akad. Nauk Zool. Inst. (n.s. 38) $7: 208$.

This genus is known to us only through the Borchsenius presentation where it was considered to be identical with Phenacoccus Cockerell.

Graphaspis MacGillivray, 1921, The Coccidae, p. 310.

TXPE-SPECIES : Chionaspis permutans Green, 1899, by original designation and monotypy.

Rao, 1949: 59-60, placed this name as a synonym of Unaspis MacGillivray, 1921, and Balachowsky, 1954e : 288, accepted his placement.

Greenacoccus MacGillivray, 1921, The Coccidae, p. 474.

This new name was proposed by MacGillivray for his Greeniella (p. 70) which was preoccupied by Greeniella Cockerell, 1897. Morrison, 1928: 163, placed the name as a synonym of Drosicha Walker, 1858.

Greenaspis MacGillivray, 1921, The Coccidae, p. 307.

TYPE-SPECIES : Mytilaspis elongata Green, 1896, by original designation and monotypy.

This has been accepted by recent coccid workers as zoologically valid. Balachowsky, 1954e: 171, 276, suggested a relationship to Pinnaspis Cockerell and assigned it to his Diaspidina, chionaspiform. 
Greenella MacGillivray, 1921, The Coccidae, pp. 75, 474.

A lapsus for Greeniella MacGillivray.

Greenica Matesova, 1960, Akad. Nauk Kazakh. SSR Inst. Zool. Trudy $11: 205$.

A lapsus for Greenisca Borchsenius.

Greenidiella Fulmek, 1943, Ent. Beihefte aus Berlin-Dahlem 10: 34.

A lapsus for Greeniella Cockerell.

Greeniella Cockerell, 1897, American Nat. 31:703.

TYPE-SPECIES: Aonidia cornigera Green, 1896, by original designation and monotypy.

This genus has been accepted as zoologically valid by Ferris, 1937c: 51, 54; 1937e: 529, and by Balachowsky, 1958b: 269. Balachowsky, 1958b: 342, referred to a Greeniella Leonardi which he placed as a synonym of Decoraspis Ferris, and assigned to his Gymnaspidina, Parlatorini. In our opinion this action thoroughly confused the status of Greeniella. All Leonardi citations that we have seen credit this genus to Cockerell and the Ferris proposal of Decoraspis was entirely unnecessary since it was based on the same type-species as the validly established Greeniella Cockerell, 1897. See Decoraspis Ferris.

Greeniella (non Cockerell, 1897) MacGillivray, 1921, The Coccidae, pp. $70,75,474$.

TYPE-SPECIES : Monophlebus stebbingii Stebbing, 1902, by original designation.

MacGillivray discovered the existence of Greeniella Cockerell, 1897, prior to the printing of his book and at its end (p. 474) substituted Greenacoccus for Greeniella MacGillivray, non Cockerell. Zoologically the concept seems identical with Drosicha Walker, 1858, so this and the other involved names have been placed in synonymy under Drosicha by Morrison, 1928: 163.

Greenisca Borchsenius, 1948, Akad. Nauk SSSR Dok. (n.s.) 60: 502.

TYPE-SPECIES : Eriococcus inermis Green, 1915, by original designation and monotypy.

The genus places in the group currently called the Eriococcidae and is accepted there by Hoy, 1963, New Zeal. Dept. Sci. and Indus. Res. Bul. 150: 9.

Greenoidea MacGillivray, 1921, The Coccidae, p. 392.

TYPE-SPECIES: Aspidiotus (Targionia) phyllanthi Green, 1905, by original designation and monotypy.

Ferris, 1941d: SIII-347, and Balachowsky, 1951: 587, placed this name as a synonym of Melanaspis Cockerell, 1897. 
Greenoripersia Bodenheimer, 1929, in Bodenheimer and Theodor, Ergebnisse der Sinai Expedition 1927, iv : 112; 1951, Ent. Ber. 13: 329.

TYPE-SPECIES: Greenoripersia kaiseri Bodenheimer, 1921, by original designation and monotypy.

As is indicated by the describer, this genus belongs in the Pseudococcidae as currently accepted. The genus was ralidly established when presented and the reasons for its representation are not evident, although the later description does provide more detailed information on the generic characteristics.

Grewiacoccus Brain, 1918, Bul. Ent. Res. 9 : 108.

TYPE-SPECIES: Grewiacoccus gregalis Brain, 1918, by original designation and monotypy.

This gall-making genus was originally described as a member of the Pseudococcidae and the recent redescription of the type-species by De Lotto, 1958a; 82 , has confirmed this assignment.

Grewiicoccus Lindinger, 1932, Konowia 11:197.

An emendation of Grewiacoccus Brain.

Grewiococcus Lindinger, 1937, Ent. Jahrb. 46 : 186.

An emendation of Grewiacoccus Brain.

Guerinia Targioni-Tozzetti, 1868, (separate) Soc. Ital. di Sci. Nat. Atti $11: 39 ; 1869,11: 724$.

TYPE-SPECIES: Guerinia tinctoria Targioni-Tozzetti, 1868, believed to be the same as Coccus serratulae Fabricius, 1775 , by monotypy.

This name was preoccupied by earlier usage in other groups and was replaced by Gueriniella Fernald.

Gueriniella Fernald, 1903, Mass. Agr. Expt. Sta. Spec. Bul. 88: [331].

TYPE-SPECIES: Guerinia tinctoria Targioni-Tozzetti, 1868, believed to be the same as Coccus serratulae Fabricius, 1775 ; by substitution of Gueriniella for Guerinia Targioni-Tozzetti.

This was presented as a replacement for Guerinia Targioni-Tozzetti. It assigns to the Margarodidae.

Guerinococcus Berlese, 1909, Gli Insetti, p. 498.

This is another replacement proposed for Guerinia Targioni-Tozzetti. It stands as a synonym of Gueriniella Fernald.

Guineaspis Balachowsky, 1952, Soc. Ent. de France Bul. 57: 98.

TYPE-SPECIES: Guineaspis mignardi Balachowsky, 1952, by original designation and monotypy.

Balachowsky placed this genus close to Pinnaspis Cockerell in his Diaspidina, chionaspiform. 
Gymnaspis Newstead, 1898, Ent. Monthly Mag. 34: 92.

TYPE-SPECIES: Gymnaspis aechmeae Newstead, 1898, by monotypy.

This genus has been accepted since its establishment. The latest assignment is that of Balachowsky, $1958 \mathrm{~b}: 342$, to his Gymnaspidina, Parlatorini.

Gymnococcus Douglas, 1888, Ent. Monthly Mag. 25 : 150; Cockerell, 1896, Ill. State Lab. Nat. Hist. 4 : 323.

TYPE-SPECIES : Coccus agavium Douglas, 1888, by monotypy.

The citations given above are presented in Neave, 1939, Nomen. Zool. II : 529. If the Douglas reference is rejected as a basis for establishment of the genus, an action which we consider to be proper, then status for the name as a coccid genus dates from Cockerell, 1893dd: 1049. The point is of academic interest only, however, since Kloet, 1944: 86, noted the use of Gymnococcus by Zopf in the Protozoa in 1884 and proposed the name Ovaticoccus as a substitute for the coccid Gymnococcus.

Haematococcus Reyne, 1961, Beaufortia (Zool. Mus. Amsterdam) 8: 127.

TYPE-SPECIES : Haematococcus obtusispinus Reyne, 1961, by original designation.

Reyne placed this genus in the Eriococcidae as defined by Ferris, 1957c: 8283, a placement confirmed by Hoy, 1963, New Zeal. Dept. Sci. and Indus. Res. Bul. 150: 9. The name is preoccupied, having been proposed previously in the Protozoa.

Halimococcoides Lindinger, 1943, Ztschr. der Wien. Ent. Gesell. 28 : 221.

TYPE-SPECTES : Fiorinia kewensis Newstead, 1901, by original designation and monotypy.

This genus assigns to the Phoenicococcidae. According to Lindinger, Halimococcus borassi Green, 1902. is identical with kewensis Newstead. Ferris, 1952: 3, assigned kewensis to Colobopyga Bréthes, 1912, with Halimococcus nesiotes Laing a synonym. There is no evidence that Ferris was familiar with Lindinger's genus Halimococcoides, but his treatment of its type-species, kewensis, will result in its placement as a synonym of Colobopyga.

Halimococcus Cockerell, 1902, Entomologist 35 : 15.

TYPE-SPECIES : Halimococcus lampas Cockerell, 1902, by monotypy.

Stickney, 1934: 6, who studied this and related genera critically, assigned it to his Phoenicococcinae.

Hallaspidiotus Mamet, 1951, Inst. Sci. de Madagascar, Mem. Ser. A, $5: 217$.

TYPE-SPECIES: Gymnaspis africana Newstead, 1913, by original designation and monotypy.

Lindinger, 1957: 549, placed the type-species as "Cryptaspidiotus africanus (Newst.) 1913," which creates a question as to the status of the genus. 
Balachorskr, 1954e: 77 , considered this name synonymous with Africonidia McKenzie, 1947. Despite Nerstead's original generic placement, the type-species is currently accepted to be aspidiotine.

Halococcus Takahashi, 1951, Mushi $22: 1$.

TYPE-SPECIES : Halococcus formicarii Takahashi, 1951, by original designation and monotypy.

Takahashi assigned this genus to the Coccidae (str.).

Haplaspis Borchsenius, 1919, Akad. Nauk SSSR Dok. (n.s.) 6t: 735.

TYPE-SPECIES : Haplaspis calligoni Borchsenius. 1949, by original designation and monotypy.

Balachorskr, 1954e: 118, 125, placed this name as a srnonsm of Ifercetaspis Gómez-Jenor, 1927. It was preoccupied by Haplaspis Tornes, 1914, in the Hymenoptera.

Helaspis McKenzie, 1963, Calif. Dept. Agr. Bul. 52 (1) : 34.

TYPE-SPECIES : Helaspis mexicana McKenzie, 1963, by original designation and monotypy.

The author established this genus in the Aspidiotini, noting a certain superficial relationship to Aspidiotus Bouché.

Heliococcus Sulc, 1912, Ceskoslor. Společ. Ent. Casopis $9: 39$.

TYPE-SPECIES : Heliococcus bohemicus Šulc, 1912, by monotypy.

This is currently accepted as a zoologically ralid genus in the Pseudococcidae.

Hemaspidis MacGillirrar, 1921, The Coccidae, p. 474.

TYPE-SPECIES: Lepidosaphes hemichionaspiformis Green, 1916, by substitution of Hemaspidis for Hemiaspis MacGillirray, 1921.

This name was presented as a substitute for Hemiaspis, preoccupied.

Hemaspidoproctus Morrison, 1927, Biol. Soc. Wash. Proc. 40: 104. TYPE-SPECIES: Thalkeriana cinerea Green, 1908, by original designation.

This genus was assigned to the Margarodidae, Monophlebinae. Monophlebini.

Hemiaspidis Ferris, 1936, Microentomology 1:21.

This is an erroneous spelling of Hemaspidus MacGillirray which Ferris, 1937: 4 , used in expressing the opinion that the genus is zoologicalls ralid. Infortunately this Ferris spelling of the generic name was also used bs Balachowsk5, 1954e: 172 , in placing the genus in his Diaspidina. group II, chionaspiform, and by Brimblecombe. 1960a : 193. in his comparison of the genus with his new genus Doriopus.

Hemiaspis MacGillirrar, 1921, The Coccidae, pp. 275, 4i4.

TYPE-SPECIES: Lepidosaphes hemichionaspiformis Green, 1916, by original designation and monotypy.

This generic name was preoccupied br prior use in Reptilia and elsewhere and was replaced by Hemaspidis MacGillirray. 
Hemiberleisa Balachowsky, 1956, Mus. Roy. du Congo Belge [Tervuren] Ann. (n. s.) Sci. Zool. 3:130.

A lapsus for Hemiberlesia Cockerell.

Hemiberlesea Lindinger, 1908, Berlin. Ent. Ztschr. (1907) 52: 96.

An emendation of Hemiberlesia Cockerell.

Hemiberlesia Cockerell, 1897, in Leonardi, Riv. di Patol. Veg. 5 : 375 ; 1897, U.S. Dept. Agr., Div. Ent., Tech. Ser. 6: 9, 12, 30.

TYPE-SPECIES: Aspidiotus rapax Comstock, 1881, through substitution of Hemiberlesia for preoccupied Aspidites Berlese and Leonardi, 1896.

Fernald, 1903b : 277, erroneously listed the first usage of Hemiberlesia as by Saccardo, 1895: 50, the combination there being "Aspidiotus cameliae." The citations offered above do not coincide with the one presented in Neave, 1939, Nomen. Zool. II : 602 , which we think is not the earliest citation of the genus. Recent coccid students have accepted Hemiberlesia as a zoologically valid aspidiotine genus, but have differed on the species that may properly be included under it.

Hemiberlesiana Thiem and Gerneck, 1934, Arb. über Physiol. u. Angew. Ent. 1:182, 230, 232 .

TYPE-SPECIES: "cameliae"-presumed to be Aspidiotus camelliae Signoret, 1869 , by original designation.

The peculiarities of the Thiem and Gerneck taxonomic method are such that information is difficult to extract from the text, but the page 232 citation does appear to include a positive type fixation although it is not certain whose "cameliae" is involved. The name becomes a synonym of Hemiberlesia through identity of type-species, for rapax Comstock and camelliae Signoret are believed to denote the same species.

Hemiberlesiella Thiem and Gerneck, 1934, Arb. über Physiol. u. Angew. Ent. 1: 132, 230, 232.

TYPE-SPECIES: [Aspidiotus] canariensis [Lindinger], 1911, by original designation.

Ferris, 1943a : 99, and Balachowsky, 1951: $650 ; 1958 \mathrm{~b}: 288$, placed this name as a synonym of Rhizaspidiotus MacGillivray, 1921.

Hemichionaspis Cockerell, 1897, Amer. Nat. 31 : 592.

TYPE-SPECIES : Chionaspis aspidistrae Signoret, 1869, by original designation.

The author presented this as a subgenus of Chionaspis Signoret. The name is currently considered a synonym of Pinnaspis Cockerell, 1892. See Ferris and Rao, 1947 : 25-27.

Hemiclonaspis Singh, 1960, The Mango, London, p. 300.

A lapsus for Hemichionaspis Cockerell.

Hemicoccus Lameere, 1936, Précis de Zoologie, Inst. Zool. TorleyRousseau, Brussels, 4 : 415 .

This name was used as an alternate to Kermes; e.g., "Hemicoccus (Kermes) vermilio et ilicis" and has no nomenclatorial standing.

$208-496-66-7$ 
Hemigymnaspis Lindinger, 1934, Ent. Rundshau 51:46; 1943. Ztschr. der Wien. Ent. Gesell. 28:221.

TYPE-SPECIES: Melanaspis (Hemigymnaspis) eugeniae Lindinger, 1934, by monotypy.

The author presented this as a subgenus of Melanaspis Cockerell and in 1943 raised it to full generic status.

Hemilecanium Newstead, 1906, Liverpool Univ., Inst. Com. Res. in Tropics Quart. Jour. 1: 71, nomen nudum; 1908, Jour. Econ. Biol. $3: 39$.

TIPE-SPECIES: (Hemilecanium theobromae Newstead, 1908)=Lecanium imbricans Green, 1903, by monotypy.

The author placed this genus in the Lecaniinae. Hall, 1932: 195, compared specimens of theobromae from Pretoria with examples of imbricans Green from India and found them to be identical. Steinweden, 1929: 236, presented a detailed description of imbricans which indicated well the generic characters.

Hemisphaerococcus Borchsenius, 1934, Survey of the Coccid Fauna of the Black Sea Coast of the Caucasus, p. 12, nomen nudum.

TYPE-SPECIES : Hemisphaerococcus rubi Borchsenius, 1934, by monotypy.

These genus and species names were presented with collection data only. Borchsenius, 1949: 300, placed them in synonymy with Coccura [Šulc] comari (Künow).

Hendaspidiotus MacGillivray, 1921, The Coccidae, p. 391.

TYPE-SPECIES : Aspidiotus uTmi Johnson, 1896, by original designation.

The validity of this genus has not been accepted by coccid workers. Ferris, 1938a: SII-202, and Balachowsky, 1956: 90, considered the name a synonym of Clavaspis MacGillivray.

Heteraspis Leonardi, 1914, Portici R. Scuola Super. di Agr. Lab. Zool. Gen. e Agr. Bol. 8 : 197.

TYPE-SPECTES : Aspidiotus replicatus Lindinger, 1909, by monotypy.

This was presented as a subgenus of Aspidiotus Bouché. According to Neave, 1939, Nomen. Zool. II : 632, the name was preoccupied by use in the Coleoptera in 1835. Ferris, 1938: 45; McKenzie, 1938: 3, and Balachowsky, 1956: 22, placed it as a synonym of Aonidiella Berlese and Leonardi.

Heterococcopsis Borchsenius, 1948, Akad. Nauk SSSR Dok. (n.s.) 61: 955 .

TYPE-SPECIES : Heterococcopsis lonicerae Borchsenius, 1948, by original designation and monotypy.

The describer placed this genus in the Pseudococcidae, close to Heterococcus Ferris. 
Heterococcus Ferris, 1918, Stanford Univ. Pub. (Univ. Ser.) 78: 34, 65 .

TYPE-SPECIES: Heterococcus arenae Ferris, 1918, by original designation and monotypy.

The describer placed this pseudococcine genus in the Phenacoccus Cockerell series. See Morrison, 1945, for detailed discussion of characteristics, relationships, etc.

Heterodera Philippi, 1884, Soc. Nac. de Agr. de Chili Bol. 15: 226 (not seen).

TYPE-SPECIES : Heterodera vitis Philippi, 1884, by monotypy.

Believing it to be a nematode, Philippi designated as Heterodera vitis ("perla de tierra") the species known today as Margarodes vitium Giard.

Hippeococcus Reyne, 1954, Leyden Rijks Mus. van Natuurlijke Hist. Zool. Meded. 32 : 237.

TYPE-SPECIES : Hippeococcus rappardi Reyne, 1954, by original designation.

The author placed this genus in the Pseudococcidae more closely allied to the myrmecophilus genera Allomyrmococcus Takahashi and Paramyrmococcus Takahashi than to others.

Horvardia Schumacher, 1918, Naturw. Ztschr. Forestl.-und Landw. $16: 228$.

A lapsus for Howardia Berlese and Leonardi.

Houardia Marchal, 1909, Soc. de Biol. [Paris] Compt. Rend. 66 : 586. TYPE-SPECIES : Houardia troglodytes Marchal, 1909, by monotypy.

The author presented a detailed description of this lecanine genus. We have found no further treatment of it or its type-species.

Hovaspis Mamet, 1954, Inst. Sci. de Madagascar, Mém. (1953) (Ser. E. Ent.) $4: 55-56$.

TYPE-SPECIES : Hovaspis perinetensis Mamet, 1954, by original designation and monotypy.

The author placed this genus in the Diaspidini but did not suggest relationship to any other genus. Lindinger, 1957:549, assigned the type-species to his Cryptaspidus.

Howardia Berlese and Leonardi, 1896, Riv. di Patol. Veg. 4: 347.

TYPE-SPECIES : Chionaspis (?) biclavis Comstock, 1883, by subsequent designation of Cockerell, 1896a : 256.

This genus has been accepted consistently by coccid workers since its description. Balachowsky, 1954e:167, 216, 250-252, placed it as an aberrant Diaspidini, Diaspidina; Williams, 1960c: 393, as an aberrant genus in the Lepidosaphina. 
Hsuia Ferris, 1950, Microentomology 15 : 70-71.

TYPE-SPECIES: Hsuia vitrea Ferris, 1950, by original designation and monotypy.

The describer piaced this genus in the Asterolecaniidae. most closely approaching Pollinia Targioni-Tozzetti. Borchsenius, 1960d:167, accepted the genus, and described a new species in it.

Hulaspis Hall, 1916, Roy. Ent. Soc., London, Trans. 97 : 520.

TYPE-SPECIES : Howardia dombeyae Hall, 1929, br original designation and monotypy.

Mamet, $1953: 251$, accepted this genus, noted the occurrence of its trpe-species in Madagascar, and, 195t:58, described a second species from Madagascar. Balachowskr, 1954e:167, placed it in his Diaspidina, group I, diaspiform. Lindinger, $1957: 549$, said the type-species "=Howardia."

Humococcus Ferris, 1953, Atlas of the Scale Insects of North America $6: 370$.

TYPE-SPECIES : Ripersia hilariae Ferris, 1919, by original designation.

The author placed this genus in the Pseudococcidae.

Hyalococcus Borchsenius, 195̌0, Akad. Nauk SSSR Dok. 71: 782.

TYPE-SPECIES : Hyalococcus mali Borchsenius, 1950, bs original designation and monotypy.

The author placed this genus in the Asterolecaniidae, near Asterolecanium Targioni-Tozzetti.

Hybridaspis Green, 1926, Bul. Ent. Res. $17: 64$.

TYPE-SPECIES: Hybridaspis producta Green, 1926, by original designation and monotypy.

The author placed this genus as allied to Fiorinia Targioni-Tozzetti. Lindinger, 1937:186, said "=Anamefiorinia Leon." Ferris, 1937a:4, considered the genus worthr of recognition after preriousls, 1936a:26, placing the name as a synonrm of Trullifiorinia Leonardi, 1906. Brimblecombe, 1960c: 193, accepted it and noted the close relationship of his genus Doriopus with it.

Hypaspidiotus Takahashi, 1956, Insecta Matsumurana 20: 23.

TYPE-SPECIES: Aspidiotus jordani Kumana, 1902, by original designation and monotypy.

The author noted that the relationships of this to other genera were not traceable.

Hypericicoccus Williams, 1961, Ent. Monthly Mag. 97: 93.

TYPE-SPECIES : Trachycoccus hyperici Ferris, 1955, by substitution of Hypericicoccus for Trachycoccus Ferris.

The author proposed this new name for Truchyenceus Ferris, 195.5: 215. homonym of Trachycoccus Borchsenius, 1950a : 781-782. 
Hypogeococcus Rau, 1938, Canad. Ent. $70: 159$.

TYPE-SPECIES : Hypogeococcus barbarae Rau, 1938, by monotypy.

The author placed this genus in the Pseudococcidae.

Iachnaspis Dunham, 1954, Bol. Inst. Biol. [Bahia] 1:66.

A lapsus for Ischnaspis Douglas.

Iberococcus Gómez-Menor, 1928, Eos 4 : 356.

TYPE-SPECIES : Iberococcus andalusicus Gómez-Menor, 1928, by original designation and monotypy.

The describer placed this genus close to Dactylopius Costa and Trabutina Marchal in the Pseudococcidae. Ferris, $1957 \mathrm{c}: 86$, suggested its reference to the Eriococcidae, and Hoy, 1963, New Zeal. Dept. Sci. and Indus. Res. Bul. 150: 9, agreed.

Iceria Signoret, 1875, Soc. Ent. de France Ann. (Bul. Ent.) (ser. 5) 5 : vi.

The word Iceria was presented here as a generic name, with a definite description but without included type-species. It appears to be a lapsus for the previously published Icerya Signoret.

Icerya Signoret, 1875, Soc. Ent. de France Ann. (Bul. Ent.) (ser. 5) 4: cclviii; 1875, Soc. Ent. de France Ann. (ser. 5) 5: 350-351.

TYPE-SPECIES : (Coccus sacchari Guérin-Méneville, 1867) =Dorthesia seychellarum Westwood, 1855, by monotypy.

The author established this margarodid genus for the single species, but over the years many more have been assigned to it. Morrison, 1928: 203, discussed it and placed it in the Iceryini, Monophlebinae. It is the most numerous in number of species and most widely distributed of the genera in this subfamily.

Iceryas Herrera, 1903, Mexico Comis. de Parasitol. Agr. Bol. (19011903) $1: 455$.

A lapsus for Icerya Signoret.

Idiococcus Takahashi and Kanda, 1939, Insecta Matsumurana 13: 52.

TYPE-SPECIES : Idiococcus bambusae Takahashi and Kanda, 1939, by original designation and monotypy.

The authors noted the resemblance of this genus to Ourococcus Fuller and suggested placement in the Cylindrococcinae. We assign it to the Antonininae, Pseudococcidae.

Idiosaissetia Brain, 1920, Bul. Ent. Res. 11:40.

TXPE-SPECIES : Idiosaissetia peringueyi Brain, 1920, by original designation and monotypy.

The author assigned this genus to the Lecaniinae. 
Imerinaspis Mamet, 1954, Inst. Sci. de Madagascar, Mém. (1953) (Ser. E. Ent.) $4: 18,60$.

TYPE-SPECIES : Imerinaspis perinetensis Mamet, 1954, by original designation and monotypy.

The author assigned this genus to the Diaspidini. Lindinger, 1957:549, called the trpe-species Cryptaspidus simitis, new name, because he had already (earlier on p. J49) placed Hovaspis perinetensis Mamet in Cryptaspidus. Mamet, 1959a: 380 , did not accept this action.

Inchoaspis MacGillivray, 1921, The Coccidae, p. 310.

TYPE-SPECIES: (Chionaspis amaniensis Lindinger, 1910)=Chionaspis dentilobis Newstead, 1910, by original designation and monotypy.

The author placed this genus in the Diaspidini and it was so listed by Ferris, 1936a: 22. without comment. Hall, 1946a: 521, accepted the genus as valid and presented a characterization. He noted that Lindinger, 1913: 75, had placed amaniensis in synonymy with dentilobis Newstead, the type-species of Remotaspis MacGillivray. This made Inchoaspis and Remotaspis isogenotypic, but Inchoaspis, with page priority retains validity. Balachowsky, 1954e: 171, placed the genus in the Diaspidina, group II, chionaspiform.

Inciaspis MacGillivray, 1921, The Coccidae, p. 311.

A lapsus for Incisaspis MacGillivray. While the above spelling was given on page 311, the author subsequently used Incisaspis in discussion of the single included species and in the index.

Incisaspis MacGillivray, 1921, The Coccidae, pp. 311, 361, 487.

TXPE-SPECIES : Diaspis pugionifera Lindinger, 1909, by original designation and monotypy.

The author placed this genus in the Diaspidini. This spelling was accepted by Ferris, 1936a: 22, and Hall, 1946a: 522, 547. Lindinger, 1937: 187, placed the name in synonymy with Diaspis Costa.

Inglina Signoret, 1882, Soc. Ent. de France Ann. (Bul. Ent.) (1881) (ser.6) 1: clvii.

This is presumably a lapsus for Maskell's Inglisia.

Inglisia Maskell, 1879, New Zeal. Inst. Trans. and Proc. (1878) 11: 213.

TYPE-SPECIES : Inglisia patella Maskell, 1879, by monotypy.

SeC Morrison and Morrison, 1922: 75, for a study of taxonomic anatomy and relationships of this coccine genus.

Inglisian Dop, 1923, Rev. Agr. New Caledonia 93 : 2.

A lapsus for Inglisia Maskell.

Insaspidiotus Barreda, in Herrera et al., 1901, Mexico Comis. de Parasitol. Agr. Bol. (1900-1903) 1:104, 229.

A "formula" mame used for species ficus, agavis and perniciosus, without status in zoological nomenclature. 
Inschionaspis Barreda, in Herrera et al., 1901, Mexico Comis. de Parasitol. Agr. Bol. (1900-1903) 1: 125-128, 222.

A "formula" name without status in zoological nomenclature.

Ins-coccus Herrera et al., 1903, Mexico Comis. de Parasitol. Agr. Bol. (1900-1903) 1:456.

A "formula" name without status in zoological nomenclature.

Ins-dactylopius Herrera et al., 1903, Mexico Comis. de Parasitol. Agr. Bol. (1900-1903) 1:457.

A "formula" name without status in zoological nomenclature.

Insiceryas Herrera et al., 1903, Mexico Comis. de Parasitol. Agr. Bol. (1900-1903) 1:5, 457 .

A "formula" name without status in zoological nomenclature.

Inslechanius Herrera et al., 1903, Mexico Comis. de Parasitol. Agr. Bol. (1900-1903) 1:207-208, 457.

A "formula" name without status in zoological nomenclature.

Insmytilaspis Herrera et al., 1900, Mexico Comis. de Parasitol. Agr. Bol. (1900-1903) 1:6.

A "formula" name without status in zoological nomenclature.

Insneolecanius Herrera et al., 1903, Mexico Comis. de Parasitol. Agr. Bol. (1900-1903) 1:457-458.

A "formula" name without status in zoological nomenclature.

Inspseudococcus Herrera et al., 1903, Mexico Comis. de Parasitol. Agr. Bol. (1900-1903) 1: 458.

A "formula" name without status in zoological nomenclature.

Insulaspis Mamet, 1950, Inst. Sci. de Madagascar, Mém. Sér. A, 4: 32-33.

TYPE-SPECIES : Lepidosaphes vermiculus Mamet, 1937, by original designation.

The author considered this genus close to Aonidomytilus Leonardi and definitely separable from Lepidosaphes Shimer. Balachowsky, 1954e: 28, 30 , placed the name in synonymy with Lepidosaphes.

Ischinaspis Kuwana, 1917, A Check List of the Japanese Coccidae, p. 18.

A lapsus for Ischnaspis Douglas.

Ischnafiorinia MacGillivray, 1921, The Coccidae, p. 372.

TYPE-SPECIES : Fiorinia bambusae Maskell, 1896, by original designation and monotypy.

Ferris, 1936a: 22, 25, accepted this as a valid genus and, 1937e: 529, rejected Lindinger's, 1937: 187, assertion that it equaled Fiorinia Targioni-Tozzetti. 
Ischnaspis Douglas, 1887, Ent. Monthly Mag. 24:21.

TYPE-SPECIES : (Ischnaspis fliformis Douglas, 1887)=Mytilaspis longirostris Signoret, 1882, by monotypy.

This genus has been accepted as valid since its establishment. It is currently placed in Diaspidini, Lepidosaphedina, by Balachowsky, 1954e: 25, 134.

Ischnofiorinia Vesey-Fitzgerald, 1940, Bul. Ent. Res. 31: 270.

A lapsus for Ischnafiorinia MacGillivray.

Jaapia Lindinger, 1914, Ztschr. f. Wiss. Insektenbiol. 10: 158.

TYPE-SPECIES: Mytilaspis (Lepidosaphes) uniloba Kuwana, 1909, by monotypy.

Lindinger, 1937: 186, 188, maintained the validity of this genus. Ferris and Rao, 1947: 27, considered the name a synonym of Pinnaspis Cockerell.

Kaicoccus Takahashi, 1958, Univ. Osaka (Prefecture) Bul. (ser. B) (1957) $7: 3,5-6$.

TYPE-SPECIES: Pseudococcus kaiensis Kanda, 1932, by original designation and monotypy.

The author placed this genus near Dysmicoccus Ferris in the Pseudococcidae.

Kandraspis Mamet, 1959, Inst. Sci. de Madagascar, Mém. (1959) (Sér. E. Ent.) 11:439-440.

TYPE-SPECIES: Kandraspis euphorbiae Mamet, 1959, by original designation and monotypy.

The author assigned this genus to the Diaspidini but could not associate it with any particular member of the group.

Karteria Berlese, 1894, Riv. di Patol. Veg. 3: 66 (footnote 1).

An emendation or lapsus for Carteria Signoret. Lindinger, 1937: 187, said "=Kerria Targioni."

Kermes Boitard, 1828, Les Gallinsectes, in Manuel d'Entomologie ou Histoire Naturelle des Insectes, $\nabla .2$ : 171.

TYPE-SPECIES: (Coccus variegatus Gmelin, 1789)=Chermes roboris Fourcroy, 1785, by subsequent designation of Fernald, 1903b : 60 .

This presents one of the more difficult problems in coccid nomenclature. In coccidological application, in recent years, Kermes has rather consistently been credited to Boitard, 1. c., where it was presented as one of the three coccid genera considered in this book. This was its first actual usage as a generic name, its prior appearances in literature having been as a common or group name. Silvestri, 1911: 148, substituted his Kermococcus for Kicrmes, without indicated reason, and named Chermes vermilio Planchon type-species. Borchsenius, 1960d: 26 , accepted this replacement as valid for Kermes auct. He considered polonicus Linnaeus, as first-included species, the type-species of Firmcs, which made that genus isogenotypic with Porphyrophora Brandt. We do not accept either of these actions, and believe that Kermes Boitard is nomenclatorially valid and available for the oak-infesting species now going under that name. Sce also under Talla Heyden. 
Kermesococcus Cromartie, 1959, Ann. Rev. Ent. 4 : 61.

Editorial lapsus for Kermes Boitard or Coccus Linnaeus.

Kermesoides Signoret, 1869, Soc. Ent. de France Ann. (ser. 4) 8: 862. TYPE-SPECIES : Targionia nigra Signoret, by implication.

Signoret stated, "Targ. nigra Signoret, nov. spec. (Kermesoides id. olim)." Lindinger, 1933e : 68, and Ferris, 1943a : 91, accepted Kermesoides as an alternate specific name for nigra. We disagree with this interpretation and consider it to be a generic name that Signoret had earlier placed on specimens of nigra.

Kermicus Newstead, 1897, Ent. Monthly Mag. 33 : 170.

TYPE-SPECIES : Kermicus wroughtoni Newstead, 1897, by monotypy.

This genus assigns to the Pseudococcidae.

Kermococcus Silvestri, 1911, Dispense di Entomologia Agraria secondo le Lezioni del Prof. F. Silvestri raccolte dal Dott. Guido Grandi. Parte Speciale. Portici, p. 148.

TYPE-SPECIES: Chermes roboris Fourcroy, 1785, by substitution of Kermococcus for Kermes Boitard.

The author presented this, without comment, as a new name for Kermes Boitard, accompanied by a discussion of one species, vermilio Planchon. Leonardi, $1920: 266$ (footnote), quoted Silvestri's reason for the change as the similarity of the name Kermes to Chermes, of earlier date, used in the Aphidoidea. Silvestri, 1939 : 692, definitely cifed Chermes vermilio Planchon as the type-species of this genus. Ferris, 1921: 157, rejected the Silvestri substitution as not justified under the International Code. Lindinger, 1928: 107, listed Kermococcus as a synonym of Kermes and later, 1933a: 117, replaced Kermes with Talla Heyden. Borchsenius, $1960 \mathrm{~d}$ : 25-26, accepted and used Kermococcus as a proper replacement for Kermes auct. See under Kermes.

Kerria Targioni-Tozzetti, 1884, Min. di Agr. Indus. e Com., Ann. di Agr. 1884 (Nos. 86-89) : 410.

TYPE-SPECIES : Coccus lacca Kerr, 1782, by monotypy.

Targioni's manner of presenting this name implied that he had proposed it prior to the presentation of the name Carteria signoret, 1874. We have found no trace of it in any earlier Targioni literature. See discussion under Laccifer Oken.

Kiritshenkella Borchsenius, 1948, Akad. Nauk SSSR Dok. (n.s.) 63: 583.

TYPE-SPECIES : Kiritshenkella stataria Borchsenius, 1948, by original designation and monotypy.

The author placed this genus close to Neotrionymus Borchsenius in the Pseudococcidae.

Koroneaspis Bodenheimer, 1943, Iraq. Dir.-Gen. Agr. Bul. 28:9.

TYPE-SPECIES : Lepidosaphes aegilopos Koronéos, 1934, by monotypy.

Balachowsky, 1954e :24, 98-99, accepted this as a valid genus close to Lepidosaphes Shimer. Borchsenius, 1949b: 343, added a second species, lonicerae. 
Kuwanaia Lindinger, 1953, Ztschr. der Wien. Ent. Gesell. 28 : 221.

An emendation of Kuwania Cockerell.

Kuwanaspis MacGillivray, 1921, The Coccidae, p. 311.

TYPE-SPECIES : Chionaspis (?) hikosani Kuwana, 1902, by original designation and monotypy.

This genus is accepted as valid in the Diaspidini by modern coccid workers. Balachowsky, 1954e: 261, placed it in the Diaspidina, group II, chionaspiform, near Stramenaspis Ferris and Madagaspis Mamet.

Kuwaneia Lindinger, 1937, Ent. Jahrb. 46:187.

An emendation of Kuwania Cockerell.

Kuwania Cockerell, 1903, in Fernald, Mass. Agr. Expt. Sta. Spec. Bul. $88: 32$.

TYPE-SPECIES : Sasakia quercus Kuwana, 1902, by substitution of Kuwania for Sasakia Kuwana.

This name was first presented in the Fernald Catalogue as a replacement for Sasakia Kuwana, preoccupied, but with definite credit to Cockerell as author. Cockerell, 1909: 56, included the genus in a table of genera allied to Xylococcus Löw (Margarodinae, Xylococcini). Morrison, 1928: 64, placed it with Neosteingelia Morrison in the Kuwaniini and redescribed the genus as limited to the type-species.

Kuwanina Cockerell, 1903, in Fernald, Mass. Agr. Expt. Sta. Spec. Bul. 88: 121.

TYPE-SPECIES: Sphaerococcus parvus Maskell, 1897, by original designation and monotypy.

This generic name appeared first in the Fernald Catalogue with Cockerell as author. Green, 1915a:181, redescribed the type-species in detail. Ferris, 1918b: 324, grouped the genus with his new genera Ehrhornia and Paludicoccus in the Dactylopiinae (of the Fernald Catalogue). In 1941 he added Rhodania Goux and Cucullococcus Ferris to the group, and suggested the possibility of their inclusion in the Pseudococcidae. Mamet, 1954: 30, noted a relationship with his pseudococcid genus Paulianodes. Takahashi, 1958: 1, also suggested reference of Kuwanina to the Pseudococcidae.

Labidaspis Borchsenius and Williams, 1963, Brit. Mus. (Nat. Hist.) Ent. Bul. $13: 378$.

TYPE-SPECIES: Fiorinia myersi Green, 1929, by original designation and monotypy.

The authors placed this genus in the Parlatoriini and noted that its relationships are rather obscure but that the second-stage female comes nearest to Doriopus Brimblecombe. 
Labioproctus Green, 1922, The Coccidae of Ceylon. Part V, p. 453.

TYPE-SPECIES: Walkeriana polei Green, 1896, by original designation and monotypy.

The author placed this genus in the Monophlebinae, allied to Aspidoproctus Newstead. Morrison, 1928: 145, assigned it to group 2 of the Monophlebini. Only the type-species has been assigned to the genus.

Laboulbenia Lichtenstein, 1877, Schweiz. Ent. Gesell. Mitt. 5: 299.

TYPE-SPECIES : Laboulbenia brachypodii Lichtenstein, 1877 , by monotypy.

The author presented this name with brief habit notes. Three pages later, in a footnote, he expressed the opinion that this insect was Antonina purpurea of Signoret, a synonymy that has been accepted by subsequent coccid workers.

Lac Anderson, 1790, Asiatic Researches (Asiatic Soc. Bengal, Trans.)

$2: 359$.

In his introductory letter to the Roxburgh 1790 article describing the lac insect, Anderson said: "Mr. Roxburgh's discovery will bring Lac a genus into the class Hemiptera of Linnaeus." There was no obvious use of the binomial system in this presentation.

Lacanium Lelong, 1890, Calif. State Bd. Hort. Ann. Rpt. for 1889 : 193.

A lapsus for Lecanium Burmeister.

Lacca Signoret, 1869, Soc. Ent. de France Ann. (ser. 4) 8: 848.

Lacca alba Pearson, Trans. Phil. (1794) : 383, was cited as a synonym of Ceroplastes ceriferus Anderson.

Laccifer Oken, 1815, Lehrbuch der Naturgeschichte, Sect. 3 (Zool. 1) : 430.

TYPE-SPECIES : Coccus lacca Kerr, 1782, by monotypy.

Kirkaldy, 1906: 249, first noted the priority of this name over Tachardia Blanchard, 1886, and it was again resurrected by Cockerell, 1924: 47. Chamberlin, 1925, accepted Laccifer as a substitute for Tachardia R. Blanchard and since then the name has found general use in entomological literature. Lindinger, 1933b : 228, pointed out that the names in the Oken Lehrbuch were not consistently binomial, hence not valid, and restored Tachardia for this zoological unit. Later in the same year, 1933a: 166, he reported that the name Kerria Targioni-Tozzetti, 1884, had priority over Tachardia and hence must replace it. Other authors have not accepted this action. The International Commission on Zoological Nomenclature (Bul. Zool. Nomen., 11 May 1951, 9(7) : 193218) undertook an extended study of the Oken Lehrbuch and produced an informal finding that Lehrbuch volume 3 is not consistently binomial and that its names therefore do not acquire arailability from such publication. This seems to confirm the Lindinger conclusion, although the Oken presentation of this particular genus was strictly binomial. It is concluded that further changes in the basic name of the lac insects will not be seriously disruptive since several have already been made (from Carteria Signoret to Tachardia to Laccifer to Kerria) and since many of the species already described in Tachardia have been transferred to other genera in consequence of Chamberlin's work. 
Lachnocecis Amyot, 1847, Soc. Ent. de France Ann. (ser. 2) 5: 503.

A monomial designation to replace a generic and specific name. It has no validity as a generic name.

Lachnodiella von Ihering, 1907, Bot. Jahrb. 39: 680, nomen nudum; Hempel, 1910, Rev. Mus. Paulista [Sao Paulo] 8: 52.

TYPE-SPECIES: Lachnodiella cecropiae Hempel, 1910, by original designation and monotypy.

Ferris, 1955: 2, redescribed the type-species of this pseudococcine genus and noted certain resemblances to Lachnodius Maskell.

Lachnodiopsis Borchsenius, 1960, Ent. Obozr. 39 : 923.

TYPE-SPECIES: Lachnodiopsis szemaoensis Borchsenius, 1960, by original designation.

The author placed this genus close to Delococcus Ferris and Lachnodiella Hempel in the Pseudococcidae.

Lachnodius Maskell, 1896, New Zeal. Inst. Trans. and Proc. (1895) $28: 400$.

TYPE-SPECIES : Dactylopius eucalypti Maskell, 1892, by designation of Fernald, $1903 \mathrm{~b}: 95$.

Morrison and Morrison, 1922: 44 48, redescribed this genus and its type-species. They expressed the opinion that it was not closely related to the Pseudococcus Westwood group of genera and suggested a possible connection with Sphaerococcopsis Cockerell. Ferris, 1955: 1, also commented on the uncertainty of its position in the Pseudococcidae.

Lackshadia Mahdihassan, 1931, Zool. Anz. 94: 296.

A lapsus for Lakshadia Mahdihassan.

Lacombia Goux, 1940, Soc. d'Hist. Nat. l'Afrique du Nord, Bul. 31 : 62.

TYPE-SPECIES : Ripersia bouhelieri Goux, 1938, by original designation and monotypy.

The author presented this as a subgenus of Ripersia Signoret, characterized chiefly by the absence of multilocular glands.

Lacsha Roxburgh, 1790, Asiatic Researches (Asiatic Soc. Bengal, Trans.) 2: 361 .

Mahdihassan, 1935a, stated that this name has priority over Laccifer Oken, 1815. We have found no hint of a binomial treatment of the name in this citation and consider it a colloquial or common name.

Lagosinia Cockerell, 1899, Canad. Ent. 31:332.

TYPE-SPECIES: Lecanium strachani Cockerell, 1898, by original designation and monotypy.

This genus and species of the Coccidae (str.) have not been studied since Cockerell's original treatment. 
Laingaspis Borchsenius and Williams, 1963, Brit. Mus. (Nat. Hist.) Ent. Bul. $13: 364$.

TYPE-SPECIES: Poliaspis lanigera Laing, 1929, by original designation and monotypy.

The authors placed this genus in the Diaspidini, set apart from other members of the tribe by the position and character of the pygidial ducts.

Laingiococcus Morrison, 1945, Wash. Acad. Sci. Jour. 355 : 54.

TYPE-SPECIES : Heterococcus painei Laing, 1930, by original designation and monotypy.

Williams, 1960:400, accepted this genus in the Pseudococcidae and redescribed the type-species.

Lakshadia Mahdihassan, 1923, Vizianagaram, India, Maharajah's Col. Sci. Assoc. Jour. 1: 98.

TYPE-SPECIES : Lakshadia indica Mahdihassan, 1923, new name for Tachardia lacca (Kerr), by substitution.

The author proposed the use of this name derived from laksha, the Sanskrit word for lac, to indicate the true lac insect and the retention of Tachardia for the pseudolac insects. No definite type designation was made but the name Lakshadia indica was substituted for the Tachardia lacca found on Butea frondosa. The situation was further confused by the proposal of sereral new specific names for various components of the previous Coccus lacca of authors complex, based largely on the color of the lac produced. Coccid workers have not accepted this generic substitution and the International Rules of Nomenclature do not permit it.

Laminicoccus Williams, 1960, Brit. Mus. (Nat. Hist.) Ent. Bul. 8 : 402.

TYPE-SPECIES : Tylococcus giffardi Ehrhorn, 1916, by original designation.

The author described this genus in the Pseudococcidae. He noted that it lacked a claw denticle but showed some other similarities to Rastrococcus Ferris and Puto Signoret of the Phenacoccus Cockerell series.

Lapazia Ferris, 1937, Atlas of the Scale Insects of North America (ser. 1) [ . 1]:SI-68.

TYPE-SPECIES : Lepidosaphes obtecta Ferris, 1921, by original designation and monotypy.

The author assigned this genus to the Diaspidini with the suggestion of a connection with Pallulaspis Ferris and perhaps Situlaspis MacGillivray. Balachowsky, $1954 \mathrm{e}: 23$, included it in his Lepidosaphedina.

Lattaspidiotus MacGillivray, 1921, The Coccidae, pp. 457-458.

TYPE-SPECIES: Aspidiotus (Diaspidiotus) tesseratus de Charmoy, 1899, by original designation.

The author assigned this genus to the Aspidiotini. The name was placed as a synonym of Duplaspidiotus MacGillivray by Ferris, 1937c: 51, 55, 1938a: SII226 ; and Balachowsky, 1951 : 680, $1953 \mathrm{i}: 1512$. 
Leacaspis Schmidt, 1956, Bioloski Glasnik (1955) 8:79.

A lapsus for Leucaspis Targioni-Tozzetti.

Leachia Signoret, 1876, Soc. de France Ann. (1875) (ser. 5) 5: 359.

TYPE-SPECIES: Monophlebus fuscipennis Burmeister, 1835, by subsequent designation of Cockerell, 1902q : 233.

Replaced by Palaeococcus by Cockerell, $1894: 36$, because of preoccupation in Mollusca. See Morrison, 1928, for details.

Lecamium Leuckart, 1858, Zur Kenntniss des Generations Wechsels und der Parthenogenesis bei den Insecten, pp. 38, 43, 112.

A lapsus for Lecanium Burmeister.

Lecaniochiton Lindinger, 1932, Konowia 11:197.

An emendation of Lecanochiton Maskell.

Lecaniodiaspis Signoret, 1870, Soc. Ent. de France Ann. (ser. 4) 10: 272.

A lapsus for Lecanodiaspis Targioni-Tozzetti, 1869. See Lecanodiaspis.

Lecaniodrosicha Takahashi, 1930, Formosa Govt. Res. Inst. Dept. Agr. Rpt. 48: 29-30.

TYPE-SPECIES : Lecaniodrosicha lithocarpi Takahashi, 1930, by original designation and monotypy.

The describer related this genus to Aspidoproctus Newstead and its allies in the Margarodidae.

Lecaniopsis Lindinger, 1923, Ent. Jahrb. 32 : 148-149.

An emendation of Lecanopsis Targioni-Tozzetti.

Lecanium Burmeister, 1835, Handb. der Ent. 2 (1) : 69.

TYPE-SPECIES : Coccus hesperidum Linnaeus, 1758, by subsequent designation of Cockerell, $1893 \mathrm{~g}: 49$.

Burmeister was the first to present this name in print, crediting it to Illiger, but nothing has been found in literature to justify acceptance of Illiger as author. No definite type designation was made but detailed descriptions were given for five species of which $L$. hesperidum (Coccus hesperidum Linnaeus) stood first. A final paragraph listed five other species "which must belong in this genus," among them Coccus tiliae Linnaeus and Coccus coryli Linnaeus. Westwood, 1840 : 118, listed "Lecanium Ill. (L. hesperidum Linn., Burm ... .)" which has been accepted by some as a type designation. Howerer, the first definite type designation was made by Cockerell, 1893g: 49, when, discussing the Signoret 1873 division of the genus Lecanium into six groups of genera, he stated: "First Series. Consists of flat and often viviparous species of which $L$. hesperidum L. may be taken as type." In the same article he proposed Eulecanium as a subgeneric name "taking $L$. tiliae as the type," for the third series, "hemispherical species with skin more or less tessellated, living on trees and shrubs in North America and Europe." This described the zoological unit that has appeared in literature over the years under the name of Lecanium. 
Cockerell, 1901c: 91 , and 1902k : 453, reported that Lecanium Burmeister, 1835, with the same type-species as Calymnatus Costa, 1828, must be abandoned in favor of the prior genus. Fernald, 1903b: 167, accepting Cockerell's conclusion, placed Lecanium and the Costa genera Calymmata and Calypticus as synonyms of Coccus Linnaeus with type-species hesperidum Linnaeus. Green, 1904d: 248 and 1922:461, recognized the suppression of Lecanium in favor of Coccus, but continued to use the name Lecanium for this zoological unit that "has nerer been known under any other generic name." Sanders, 1909:430, autocratically set persicae (Fabricius) as type-species of Lecanium, because "all the species Burmeister really placed under this genus have been remored to other genera except persicae" and "it is impossible to eliminate Lecanium from our Coccid nomenclature." There is no rule that will permit this action. Steinweden, 1929:225, accepted this genus as Lecanium Inliger with type-species "Coccus tiliae Linnaeus or Coccus coryli Linnaeus" but the facts detailed abore show no justification for such a presentation. Šulc. 1908:36, recognized Eulecanium Cockerell as a genus that included most Palearctic species (not in hot houses) of the genus Lecanium (sensu Signoret) and proposed the remoral of certain of the species haring salient differential characters to three new genera. In his 1923 paper, Šulc used the name Lecanium, demoting to subgenera the four previously recognized generaEulecanium Cockerell, Palaeolecanium Šulc, Parthenolecanium Šulc, and Sphaerolecanium Šulc. Kawecki, 1958, followed this Šulc usage. Borchsenius, 1957: 384, 423 , acceded to the suppression of Lecanium, and accepted the three Sulc subgenera and Eulecanium Cockerell as valid genera. See Eulecanium for further details.

Lecanochiton Maskell, 1882, New Zeal. Inst. Trans. and Proc. (1881) $14: 222$.

TYPE-SPECIES: Lecanochiton metrosideri Maskell, 1882, by monotypy.

Morrison and Morrison, 1922: 69-75, redescribed this coccine genus and its type-species, but were unable to offer suggestions as to its relationships.

Lecanodiaspis Targioni-Tozzetti, 1869, Soc. Ent. Ital. Bul. 1: 261.

TYPE-SPECIES: Lecanodiaspis sardoa Targioni-Tozzetti, 1869, by monotypy.

Signoret, 1870: 285, used this spelling, agreeing with the Targioni original presentation, in his index and in his detailed treatment of the genus and its single associated species. The spelling Lecaniodiaspis, which appeared on page 272 of Signoret's work, we believe to be a lapsus and, although it has been in general use in literature for many years, should gire way to Lecanodiaspis Targioni-Tozzetti, 1869. Borchsenius, 1959a: 840, erected a new family, the "Lecaniodiaspididae," to include this genus and sereral others previously placed in the Asterolecaniidae.

Lecanopsis Targioni-Tozzetti, 1868, (separate) Soc. Ital. di Sci. Nat. Atti $11: 36 ; 1869,11: 729$.

TYPE-SPECIES: Lecanopsis rhyzophila Targioni-Tozzetti, 1868, by monotypy.

Targioni, $1867: 23$, first mentioned this lecanine hjpogeous genus as Rhizobium, referring to it a "large species found near the roots of an Asperula." This name, emended to Rhyzobium, appeared in his catalog, 1868: 36, as a synonym of "Lecanopsis nob., gen. nor." with species "rhyzophila nob., n. sp." Signoret, 1874: 93, published the first formal characterization of the genus as quoted notes 
and two drawings sent to him by Targioni. The type-species has never been rediscovered. The present-day concept of the genus began with Newstead, 1893e : 205, who extended the characters of the genus to include his new species formicarum. The number of species referred to this genus by various authors has reached 15, according to Borchsenius, $1957: 91$, who published the most recent review of the genus. He placed Lecanopsis in the Filippiinae of the Coccidae (str.) and presented a precise generic recharacterization based on published descriptive notes of other authors and the species he had described.

Leconium Kirchner, 1856, Lotus $6: 218$.

A lapsus for Lecanium Burmeister.

Ledaspis Hall, 1946, Roy. Ent. Soc., London, Trans. 97 : 522.

TYPE-SPECIES: Chionaspis (Dinaspis) mashonae Hall, 1928, by original designation.

The author placed this genus in a group of genera of the Phenacaspis Cooley and Cockerell complex of the Diaspidini, closest to Tecaspis Hall. Balachowsky, $1954 \mathrm{e}$ : 549 , accepted it as a member of the Diaspidina, group II, chionaspiform.

Lef roya Lindinger, 1937, Ent. Jahrb. $46: 187$.

A lapsus for Lefroyia Green.

Lefroyia Green, 1908, India Dept. Agr. Mem., Ent. Ser. 2 : 21.

TYPE-SPECIES: Lefroyia castaneae Green, 1908, by original designation and monotypy.

Preoccupied by Lefroyia Jones, 1874, in Pisces, according to Neave, 1939, Nomen. Zool. II : 884. The type-species is synonymous with Pseudopulvinaria sikkimensis Atkinson, hence the name falls into synonymy with Pseudopulvinaria Atkinson.

Leocaspis Gómez-Menor, 1957, Eos $33: 49$.

A lapsus for Leucaspis Targioni-Tozzetti.

Leococcus Kanda, 1959, Kontyu $27: 239-240$.

TYPE-SPECIES: Leococcus erigeroneus Kanda, 1959, by original designation and monotypy.

The author considered this genus closely allied to Puto Signoret or Ceroputo Šulc in the Pseudococcidae.

Leonardaspis MacGillivray, 1921, The Coccidae, p. 274.

TYPE-SPECIES : Mytilaspis wilga Leonardi, 1903, by original designation and monotypy.

The author assigned this genus to the Lepidosaphini. Lindinger, 1937: 187, placed it in synonymy with Mytilococeus Amerling (Lepidosaphes Shimer). Borchsenius and Williams, 1963, Brit. Mus. (Nat. Hist.) Ent. Bul. 13: 366, considered it a distinct genus, in certain features close to Berlesaspis MacGillivray. 
Leonardianna MacGillivray, 1921, The Coccidae, p. 393.

TYPE-SPECIES : Aspidiotus pimentae Newstead, 1917, by original designation.

Lindinger, 1937 : 188, placed this name as a synonym of Dycryptaspis Cockerell. Ferris, 1941d: SIII-345, accepted it as valid and placed it in the Aspidiotini. Balachowsky, 1953g: 727, 731, attached it provisionally to the Odonaspidina.

Lepidaspidis MacGillivray, 1921, The Coccidae, p. 275.

TYPE-SPECIES : Mytilaspis uniloba Kuwana, 1909, by original designation and monotypy.

The author placed this genus in the Lepidosaphini. Lindinger, $1937: 188$, said, "=Jaapia Ldgr." Ferris and Rao, 1947:26-27, placed the name in synonymy with Pinnaspis Cockerell.

Lepidaspis Riley, 1923, Zool. Rec. for 1921, p. 249.

A lapsus for Lepidaspidis MacGillivray. Lindinger, 1937 : 188, said, "=Jaapia Ldgr."

\section{Lepidosaphes Shimer, 1868, Amer. Ent. Soc. Trans., pp. 372-373.}

TYPE-SPECIES: (Coccus conchiformis Gmelin, 1789, of Shimer)=Coccus $u l m i$ Linnaeus, 1758 , of current concepts, by monotypy.

Signoret, 1870:91, claimed that Mytilaspis Targioni-Tozzetti, 1868, was published earlier than Lepidosaphes, but we have found nothing to confirm this. Lindinger, 1936:148-149, insisted that the generic name Mytilococcus Amerling, 1858, had precedence over Lepidosaphes Shimer, 1868. For good reasons we question this substitution. The name appeared in three different spellings in the year of its publication, first as Mytillicoccus Amerling without included species, second as Mytilococcus Amerling with included species and illustrations but no actual descriptions, and third as Mytilicoccus in a review by von Schlechtendal of Amerling's work. There is no generic description to associate with the name and no specific descriptions associated with any of the forms named in association with Mytilococcus. A few coccid workers have utilized the name Mytilococcus since its rediscovery by Lindinger, but most current workers (Balachowsky, Borchsenius, Ferris, Hall, Schmutterer, Takahashi) have continued to use Lepidosaphes. Thus far Mytilococcus has been used in coccid literature perhaps 150 to 200 times; Lepidosaphes has built up a usage running to 3,500 to 4,000 times, and is common in current usage. There are practical advantages in continuing the use of the latter name, and we believe that its use should be accepted, and stabilized by formal action if necessary.

The question of the status of the type-species of Lepidosaphes and its synonyms presents its own problems. Cockerell, $1899 \mathrm{j}: 275$, apparently was the first to note that Coccus ulmi Linnaeus, 1758:455, was based on Reaumur's "Insectes 4. t. 2, 5. f. 5-7." Fernald, 1903b: 314, placed Coccus linearis Modeer, 1778, and Coccus conchiformis Gmelin, 1789, both bearing their author's citations to the same Reaumur plate figures noted above, in synonymy with Coccus ulmi Linnaeus. The acceptance of $u l m i$ Linnaeus over the several other names used for this species, first in Mytilaspis and after publication of the Fernald Catalogue, 1903b, in combination with Lepidosaphes, has become very widespread, if not universal, and we believe it is correct. We believe further that continued use of conchiformis (Gmelin) as a valid name (see Balachowsky, 1954e: 64), and the attempt to resurrect the name linearis (see Lindinger, 1954:617) are arbitrary actions not legitimate under the Rules of the 1961 Code.

$208-496-66-8$ 
Lepidosaphoides Lindinger, 1930, Hamburg. Inst. f. Angerr. Bot. Jahresber. (1929) : 106.

TYPE-SPECIES: Leucaspis bambusae Kuwana, 1902, by monotsps.

Balachorshr, 195te: 264: Borchsenius and Hadzibejli, 1950: 12: and Ferris, 1936a: 22-25, hare accepted this name as a srnonrm of Kuranaspis MacGillirray, 1921.

Leptococcus Reyme, 1961, Beaufortia (Zool. Mus. Amsterdam) 8:145.

TYPE-SPECIES: Leptococcus metroxyli Rerne. 1961, br original designation and monotsps.

The author placed this genus in the Pseudococcidae allied to Pseudococcus Testrood.

Leptopulvinaria Kanda, 1960, Kontyu 28:118.

TrPe-specIes: Leptoputrinaria e?aeocarpi Kanda, 1960 bs original designation and monotsps.

The author noted resemblance of this genus to Pulvinaria Targioni-Tozzetti.

Leucamium Breter, 1862, Soc. Ent. Belge Ann. 6: 9 T.

A lapsus for Lecanium Burmeister.

Leucanium Schaum, 1850, Arch. f. Naturgesch. 16, Bd. 2: 248-219.

Lindinger, 1951: 616. claimed ralid status for this as a generic name and maintained that it should replace Eutecanium Cocherell. Afier careful examination of the publication by Schaum, Te reject Lindinger's conclusions and consider that this spelling is a lapsus for Lecanium Burmeister.

Leucaspidopsis Lindinger, 1932, Konowia 1:202-203.

TYPE-sPECIES : Leucaspis vayssierei Balachomskr, 1928, br original designation.

The author presented this genus with a brief descriptire note and included also Fiorinia mastielli Brittin. Ferris, 193id: 104, considered the genus possibly ralid but the name $\pi$ as placed as a srnonrm of salicicola Lindinger br Balachowfks and Kaussari, 1951: [1], and b5 BalachowskJ, 1953g: 882-883.

Leucaspis Targioni-Tozzetti, 1868, (separate) Soc. Ital. di Sci. Nat. Atti 11: 11; 1869, 11: 731; Signoret, 18 7 , Soc. Ent. de France Ann. (ser. 4) $10: 100$.

TYPE-SPECIES: (Leucaspis candida Targioni-Tozzetti, 1sGs) =Coccus pini Hartig, 1 33, br subsequent designation of Targioni-Tozzetti, 1S81: 160.

The author presented this generic name in his 1865 catalog with no descriptire or other associated information, but with two included species names: "sp. 1 . Leucaspis candila nob. (Dispis candida nob. 15ti)" and "sp. 2. Leucaspis signorti nob. n. sp. $150 s$ (D. signoreto recepta. Pini sp. incola)." We hare failed to find Diaspis candida in ans other Targioni publication. Signoret. 18i0: 100-102, save substance to Lcucaspis, which he crealiced to Targioni, with descriptions of the genus and the two species that had been included, but placed 
candida Targioni as a synonym of Coccus pini Hartig, 1839. We consider Targioni's, 1881: 160, comment, "We are not even now in a position to determine Whether a species sent to Signoret by us as type of the genus (Leucaspis candida) is or is not distinct from Leucaspis pini described by Hartig," a definite type designation. Burmeister, 1835, Arch. f. Naturgesch. 1 (2) : 47, in commenting on Walker's treatment of a chalcid family, Leucopsidae, stated in a footnote that the generic name, Leucopsis, was erroneously formed and should be Leucaspis. On this fact certain coccid workers have based their opinion that the name Leucaspis could not be used in the Coccoidea because of preoccupation in the Hymenoptera. Hymenopterists, in general, have not accepted this as a valid chalcid genus, and Peck, 1963, Catalogue of Nearctic Chalcidoidea, p. 893, cites Leucaspis Burmeister, 1835, as an invalid emendation of Leucospis Fabricius.

Leucaspis Targioni, 1868, has been accepted as a valid genus in the Parlatoriini by most coccid workers with the exception of Lindinger, who has insisted on replacing it with Leucodiaspis Signoret, 1869. Lindinger, 1906: 10, also rejected the use of the Hartig name as type-species on the grounds that three different coccid species can stand under it, and he, 1937: 188, cited $L$. signoreti Targioni as type-species for Leucodiaspis, which he, 1910: 190, substituted for Leucaspis. Later, 1943b : 222, Lindinger reversed himself and cited $L$. candida Targioni as type-species. We have not seen the Hartig paper but Lindinger's $1906: 32$, quotations from it present so inadequate a picture as to support his questioning the use of pini Hartig in place of candida Targioni. However, the majority of European writers have accepted the concept that pini Hartig was the first name proposed for the insect listed as Leucaspis candida by Targioni, 1868, and so, by usage, including the latest revisionary work (Balachowsky, 1953g: 127), Leucaspis pini has come to be the accepted name for both the type-species and the valid species. We believe that no accurate factual decision on this identity can ever be reached, and it seems preferable to fix the Hartig name in this status and to place the name candida Targioni in synonymy under pini.

Leucodiaspis Signoret, 1869, Soc. Ent. de France Ann. (ser. 4) 9: 99 ; Lindinger, 1908, Jahrb. der Hamburg. Wiss. Anst. (1907) 25 Beih. $3: 121$.

TYPE-SPECIES : Leucaspis candida Targioni-Tozzetti, 1868, by substitution of Lencodiaspis for Leucaspis Targioni-Tozzetti.

This generic name first appeared in Signoret, 1869, in the brief introductory characterization of genera and in the index, associated with Leucaspis. Accepting Leucaspis Targioni, 1868, as preoccupied by Leucaspis Burmeister, 1835, in the Hymenoptera (see Leucaspis), Kirkaldy, 1904a : 257, suggested its replacement by Leucodiaspis Signoret, 1869. Lindinger, 1908d: 121, repeated this proposal and subsequently insisted on its acceptance. Ferris, 1936a: 22, 25, rejected this action, considering Leucodiaspis of Signoret a misspelling of Leucaspis. We agree with the Ferris opinion that it was an unnecessary substitution. Some authors, i.e., Zimmerman, 1948: 374, and Zahradnik, 1952a: 449, have continued to use Leucodiaspis.

Lichstensia Fuller, 1899, Ent. Soc. London, Trans., pp. 457-458.

A lapsus for Lichtensia Signoret. 
Lichtensia Signoret, 1873, Soc. Ent. de France Ann. (ser. 5) 3:27. TYPE-SPECIES : Lichtensia viburni Signoret, 1873 , by monotypy.

Steinweden, 1929: 236, placed this name as a synonym of Filippia TargioniTozzetti, considering that the type-species were congeneric. Borchsenius, 1957: 188 , accepted this conclusion.

Ligulaspis MacGillivray, 1921, The Coccidae, p. 388.

TYPE-SPECIES : Odonaspis janeirensis Hempel, 1900, by original designation and monotypy.

The validity of this aspidiotine genus has not been accepted by coccid workers. The name is placed in synonymy with Odonaspis Leonardi.

Limacoccus Bondar, 1929, Bol. Biol. [Sao Paulo] 16 : 59.

TYPE-SPECIES : Limacoccus serratus Bondar, 1929, by original designation and monotypy.

The author placed this genus in the Pseudococcinae but it is currently included in the Phoenicococcidae.

Lindingaspis MacGillivray, 1921, The Coccidae, p. 388.

TYPE-SPECIES : Melanaspis samoana Lindinger, 1911, by original designation and monotypy.

Ferris, 1938a: SII-245, accepted this genus as distinct, but noting the inadequacy of the original description, based his concept of the genus on Aspidiotus rossi Maskell, which he considered congeneric with the type-species. McKenzie, 1950 : 98 , reviewed the genus and recognized samoana Lindinger as type-species, but followed Ferris in basing the morphological details of his generic characterization on rossi.

Lindingeria MacGillivray, 1921, The Coccidae, p. 248.

TYPE-SPECIES : Gymnaspis aberemoae Lindinger, 1910, by original designation and monotypy.

The author placed this genus in the Parlatoriini. Coccid workers have not accepted it as valid and distinct from Gymnaspis Newstead.

Lineaspis MacGillivray, 1921, The Coccidae, p. 308.

TYPE-SPECIES : Chionaspis striata Newstead, 1897, by original designation and monotypy.

Coccid workers have accepted this genus as valid in the Diaspidini. Balachowsky, 1954e : 401, assigned it to his Diaspidina, group II, chionaspiform.

Lipidosaphes Borchsenius, 1958, Acta Ent. Sinica 8:168.

A lapsus for Lepidosaphes Shimer.

Liuaspis Borchsenius, 1960, Akad. Nauk SSSR Zool. Inst. (n.s. 77) 8: 174.

TYPE-SPECIES: Liuaspis sinensis Borchsenius, 1960, by original designation and monotypy.

The author assigned this genus to the Asterolecaniinae. 
Liucoccus Borchsenius, 1960, Ent. Obozr. 39 : 930.

TYPE-SPECIES : Liuococcus ehrhorniodes Borchsenius, 1960, by original designation and monotypy.

The author placed this genus close to Miscanthicoccus Takahashi in the Pseudococcidae.

Llavea Lindinger, 1937, Ent. Jahrb. 46 : 188.

An emendation of Llaveia Signoret.

Llaveella Lindinger, 1937, Ent. Jahrb. 46 : 188.

An emendation of Llaviella Morrison.

Llaveia Signoret, 1876, Soc. Ent. de France Ann. (1875) (ser. 5) 5 : 370.

TYPE-SPECIES : Coccus axin Llave, 1832, by monotypy.

Morrison, 1928: 182-183, assigned this genus to the Monophlebinae, Llaveiini, and reviewed the species previously assigned to it.

Llaveiella Morrison, 1927, Biol. Soc. Wash. Proc. 40 : 108.

TYPE-SPECIES : Llaveiella taenechina Morrison, 1927, by original designation and monotypy.

The type-species of this genus is the species referred to by Cockerell, 1897u: 271, as Llaveia axin (Llave). Morrison, 1928: 182, assigned the genus to the Llaveiini, Monophlebinae.

Loemica Laing, 1929, Ann. and Mag. Nat. Hist. (ser. 10) 4: 476.

TYPE-SPECIES : Loemica ghesquierei Laing, 1929, by original designation and monotypy.

The author assigned this genus to the Coccinae (str.), closely related to Lecanopsis Targioni-Tozzetti, with which it agrees in many microscopic characters.

Lomatococcus Borchsenius, 1960, Ent. Obozr. 39 : 920.

TYPE-SPECIES: Lomatococcus ficiphilus Borchsenius, 1960, by original designation and monotypy.

The author placed this genus close to Planococcoides Ezzat and McConnell in the Pseudococcidae.

Longisomus Kiritchenko, 1931, Inst. Zashch. Rast. (1930) 7: 312, nomen nudum.

TYPE-SPECIES : Longisomus festucae Kiritchenko, 1931, by monotypy.

The author presented this name in a list of coccids, with associated collection data. Borchsenius, 1949: 185, cited it as a synonym of Metadenopus Šulc, 1933.

Lophococcus Cockerell, 1902, Entomologist 34:227, 248.

TYPE-SPECIES : Lophococcus mirabilis Cockerell, 1902, by original designation and monotypy.

A synonym of Aspidoproctus Newstead, 1901. See Morrison, 1928: 151, for details. 


\section{MISC. PUBLICATION 1015, U.S. DEPT. OF AGRICULTURE}

Lopholeucaspis Balachowsky, 1953, Actualités Sci. et Indus., Ent. Appl. 1202: 875.

TYPE-SPECIES : Leucaspis japonica Cockerell, 1897, by original designation. The author assigned this genus to his Parlatorini, Leucaspidina.

Lopococcus Handlirsch, 1925, in Schröder's Handbuch der Entomologie, p. 1136.

A lapsus for Lophococcus Cockerell.

Loranthaspis Cockerell and Bueker, 1930, Amer. Mus. Nat. Hist. Amer. Mus. Novitates 424:4.

TYPE-SPECIES: Loranthaspis microconcha Cockerell and Bueker, 1930, by monotypy.

Ferris, 1937c: 51, 55, considered this genus valid and associated it with Pygidiaspis MacGillivray in the Aspidiotini.

Lusitanococcus Neves, 1954, Portugaliae Acta Biol. (ser. B) 4:239240.

TYPE-SPECIES : Lusitanococcus arrabidensis Neves, 1954, by monotypy.

A synonym of Cucullococcus Ferris.

Luzulaspis Cockerell, 1902, Ann. and Mag. Nat. Hist. (ser. 7) 9:25. TYPE-SPECIES: Aspidiotus luzulae Dufour, 1864, by original designation and monotypy.

This genus has been accepted as distinct and valid by most modern workers. Borchsenius, 1957: 87, placed it in the Filippiinae, Coccidae (str.).

Lyraspis Ferris, 1938, Microentomology $3: 45-46 ; 1938$, Atlas of the Scale Insects of North America (ser.2) [ . 2] : SII-149.

TYPE-SPECIES : Lepidosaphes ilicis Hoke, 1927, by original designation.

The author, 1941d: SIII-302, placed this name as a synonym of Niveaspis MacGillivray. This action was accepted by Lepage, 1939: 313, and Balachowsky, 1954 e : 23.

Maconellicoccus Ezzat, 1958, Soc. Ent. d'Egypte Bul. 42: 380.

TYPE-SPECIES: Phenacoccus hirsutus Green, 1908, by original designation and monotypy.

The author placed this genus close to Paracoccus Ezzat and McConnell in the Planococcini.

Macracanthopyga Lizer y Trelles, 1955, Soc. Ent. de France Bul. 60: $37-38$.

TYPE-SPECIES: Macracanthopyga verganianus Lizer y Trelles, 1955, by original designation and monotypy.

The author placed this genus in the Eriococcidae, doubtfully. Ferris, 1957, by 87, and Hoy, 1963, New Zeal. Dent. Sci. and Indus. Res. 13ul. 150: 10, accepted this placement. 
Macrancanthopyga Ferris, 1957, Microentomology 22 : 66.

A lapsus for Macracanthopyga Lizer y Trelles.

Macrocepicoccus Morrison, 1919, Ent. Soc. Wash. Proc. 21: 197-202.

TYPE-SPECIES: Macrocepicoccus loranthi Morrison, 1919, by original designation and monotypy.

The author placed this genus in the Pseudococcidae, more closely related to Pseudococcus Westwood than to any other genus.

Macrocerococcus Leonardi, 1907, Portici R. Scuola Super. di Agr., Lab. Zool. Gen. e Agr. Bol. 1:151.

TYPE-SPECIES: Macrocerococcus superbus Leonardi, 1907, by monotypy.

This name was placed as a synonym of Puto Signoret by Ferris, 1950: 190, and accepted as such by Balachowsky, 1953n: 301. Borchsenius, 1949: 289, and Reyne, 1954a: 323, did not share this view and considered Macrocerococcus a valid genus.

Maculicoccus Williams, 1960, Brit. Mus. (Nat. Hist.) Ent. Bul. 8: 403.

TYPE-SPECIES : Trionymus malaitensis Cockerell, 1929, by original designation and monotypy.

The author placed this genus in the Pseudococcidae with no suggestion of relationship to any particular genus.

Madacanthococcus Mamet, 1959, Inst. Sci. de Madagascar, Mém. (1959) (Sér. E. Ent.) 11: 396.

TYPE-SPECIES: Madacanthococcus phitippicolus Mamet, 1959, by original designation and monotypy.

The author placed this genus in the Pseudococcidae near Synacanthococcus Morrison and Echinococcus Balachowsky.

Madagaspis Mamet, 1950, Inst. Sci. de Madagascar, Mém. (Sér. A) 4: $34-35$.

TYPE-SPECIES : Madagaspis pauliani Mamet, 1950, by original designation and monotypy.

The author placed this genus in the Diaspididae near Dentaspis MacGillivray. Balachowsky, 1954e: 265, suggested its closeness to Kuwanaspis MacGillivray.

Madarococcus Hoy, 1962, New Zeal. Dept. Sci. and Indus. Res. Bul. $146: 151$.

TYPE-SPECIES : Rhizococcus pulchellus Maskell, 1890, by original designation.

The author placed this genus in the Eriococcidae, closely associated with Eriococcus Targioni-Tozzetti, but distinguished by complete absence of the Eriococcus type of tubular ducts. 
Madeurycoccus Mamet, 1959, Inst. Sci. de Madagascar, Mém. (1959) (Sér. E. Ent.) 11: 398.

TYPE-SPECIES: Madeurycoccus guari Mamet, 1959, by original designation and monotypy.

The author placed this genus in the Pseudococcidae close to Eurycoccus Ferris and Trionymus Berg.

Madhalimococcus Mamet, 1959, Inst. Sci. de Madagascar, Mém. (1959) (Sér. E. Ent.) 11:423-425.

TYPE-SPECIES : Madhalimococcus hyphaeneae Mamet, 1959, by original designation and monotypy.

The author placed this genus in the Phoenicococcinae of the Diaspididae close to Halimococcus Cockerell. Adult females of these two genera are difficult to separate but distinctive characters are present in eggs and first- and secondstage females.

Malaicoccus Takahashi, 1950, Insecta Matsumurana 17:65.

TYPE-SPECIES: Malaicoccus riouwensis Takahashi, 1950, by original designation and monotypy.

This genus was assigned by the author to the Pseudococcinae near Allomyrmococcus Takahashi.

Malleolaspis Ferris, 1941, Atlas of the Scale Insects of North America (ser. 3) [v. 3] : SIII-290.

TYPE-SPECIES: Malleolaspis sculpta Ferris, 1941, by original designation.

The author placed this genus in the Pseudoparlatoria Cockerell group of Diaspidinae, Diaspidini.

Mallococcus Maskell, 1898, New Zeal. Inst. Trans. and Proc. (1897) $30: 242$.

TYPE-SPECIES: Mallophora sinensis Maskell, 1897, by substitution of Mallococcus for Mallophora Maskell.

The author substituted this name for Mallophora Maskell, 1897, preoccupied in the Diptera. Morrison and Morrison, 1922: 66-69, redescribed this genus as a coccine form resembling the Asterolecaniinae in certain respects.

Mallophora Maskell, 1897, New Zeal. Inst. Trans. and Proc. (1896) $29: 314$.

TYPE-SPECIES: Mallophora sinensis Maskell, 1896, by monotypy.

This name was preoccupied in the Diptera and was replaced by Mallococcus Maskell.

Mammicoccus Balachowsky, 1959, Rec. Acad. Colombiana 10:337.

TYPE-SPECIES: Mammicoccus murilloi Balachowsky, 1959, by original designation and monotypy.

The author placed this genus in the Pseudococcini next to Phenacoccus Signoret. 
Mancaspis Ferris, 1941, Atlas of the Scale Insects of North America (ser. 3) [v. 3] : SIII-293.

TYPE-SPECIES : Mancaspis lunata Ferris, 1941, by original designation.

The author placed this genus in the Diaspidinae, Diaspidini, but suggested association with no particular genus.

Marchalaspis MacGillivray, 1921, The Coccidae, p. 312.

TYPE-SPECIES : Chionaspis vuilleti Narchal, 1909, by original designation and monotypy.

Lindinger, 1937: 188, placed this name in synonymy with Chionaspis Signoret. Hall, 1946a : 525, believed the genus was valid.

Marchaliella Bodenheimer, 1951, Ent. Ber. 13 : 331.

TYPE-SPECIESS Monophlebus hellenicus Gennadius, 1883, by original designation and monotypy.

The author placed this genus in the Diaspidinae related to Chioraspis Signoret. Ferris, 1955d: 42, and Balachowsky, 1954e: 317-318, considered the name a synonym of Chionaspis.

Marchalina Vayssière, 1923, Ann. des Épiphyt. 9:427.

TYPE-SPECIES : Monophlebus hellenicus Gennadius, 1883, by original designation and monotypy.

The author placed this genus in the Monophlebinae. Morrison, 1928: 88, assigned it to the Marchalinini, Coelostomidiinae, Margarodidae.

Margarodes Guilding, 1829, Linn. Soc. London, Trans. 16: 118.

TYPE-SPECIES : Margarodes formicarum Guilding, 1829, by monotypy.

The author presented this genus in an interesting and relatively detailed paper without indication of relationship to any other insect. Morrison, 1928: 72, redescribed and discussed the genus, associating it with Neomargarodes Green in the Margarodini, Margarodinae, Margarodidae.

Marginaspis Hall, 1946, Roy. Ent. Soc., London, Trans. $97: 58$.

TYPE-SPECIES : Marginaspis thevetiae Hall, 1916, by original designation and monotypy.

The author placed this genus in the Aspidiotini between Lindingaspis MacGillivray and Acutaspis Ferris. McKenzie, 1950: 98-99, and Balachowsky, 1953c: 110, and 1958b: 164, 188-191, accepted the genus as distinct, though very close to Lindingaspis.

Margorades Hunsucker, 1956, Miss. Farm Res. 19:6.

A lapsus for Margarodes Guilding.

Marlattaspis MacGillivray, 1921, The Coccidae, p. 387.

TYPE-SPECIES : Aspidiotus implicatus Maskell, 1897, by original designation and monotypy.

The author placed this genus in the Aspidiotini. Ferris. 1938a: SII-232, listed the name as a synonym of Hemiberlesia Cockerell and the type-species as 
identical with H. lataniae Signoret. Balachowsks, 1956: 104, confirmed this action.

Marshalina Hadzibejli, 1959, Akad. Nauk Gruz. SSR Soobshch. 23: 575 .

A lapsus for Marchalina Vayssière.

Marsipococcus Cockerell and Bueker, 1930, Amer. Mus. Nat. Hist., Amer. Mus. Novitates 424:7.

TYPE-SPECIES : Lecanium marsupiale Green, 1904, by monotypy.

The authors presented this as a subgenus of Coccus Linnaeus, as characterized by Steinweden, 1929 .

Mascarenococcus Mamet, 1940, Roy. Ent. Soc., London, Proc. Ser. B : Taxonomy $9: 68$.

TYPE-SPECIES : Mascarenococcus pandani Mamet, 1940, by original designation and monotypy.

The author referred this genus to the Pseudococcinae.

Maskeliella Leonardi, 1898, in Berlese and Leonardi, Ann. di Agr. Rome (ser. 2) :12; 1898, Riv. di Patol. Veg. (1897) 6:290.

The author listed this as, "Maskeliella Leon. (Polyaspis Maskl.)" with no indication of association. Ferris, 1937a: 4, stated that Maskelliella [misspelled], arbitrarily proposed by Leonardi to replace Poliaspis Maskell, was definitely invalid.

Maskellana MacGillivray, 1921, The Coccidae, p. 490.

TYPE-SPECIES : Mytilaspis (Fernaldella) beyeriae Green, by original designation and monotypy.

The author included this genus in the "Lepidosaphini." Ferris, 1937a: 4, considered it ralid. Balachowsky, 1951e : 23, placed it in his "Lepidosaphedina."

Maskellanna MacGillivray, 1921, the Coccidae, pp. 276, 296.

A lapsus for Maskellana MacGillivray.

Maskellia Fuller, 1897, Agr. Gaz. N.S. Wales 8: 579; 1897, West. Austral. Bur. Agr. Jour. 4:1345.

TYPE-SPECIES : Maskellia globosa Fuller, 1897, by monotypy.

The author established this genus for a diaspine gall-making coccid. Lindinger, 1943b : 206-207, proposed the substitution of Austromaskellia because he considered Maskellia Fuller, 1897, preoccupied by the publication in 1896 of the name "Mastellia zonata Green" as host of a chalcid parasite. See under Austromaskellia for details. We reject Lindinger's action and consider Maskellia Fuller, 1897, a valid diaspine genus.

Maskelliella Cockerell, 1899, Ill. Nat. Hist. Survey Bul. 5 : 397.

An emendation or lapsus for Maskeliella Leonardi. Lindinger, 1937: 1S9, and Ferris, 1937a : 3-4, 6, also used this spelling. 
Matsucoccus Cockerell, 1909, Canad. Ent.41:56.

TYPE-SPECIES Xylococcus matsumurae Kuwana, 1905, by original designation and monotypy.

The author erected this genus for a single Japanese species found on pine, noting that it was related to Callipappus Guérin-Méneville. Herbert, 1921, treated the genus in detail and suggested that it was most closely related to Kuwania Cockerell, Steingelia Nassanov, and Stomococcus Ferris. Morrison, 1928: 48, discussed its relationships and placed it in the Matsucoccini, Xylococcinae, Margarodidae. Ferris, 1941: 7-8, noted that specimens found in Baltic amber belong to a genus closely related to Matsucoccus.

Mauritiaspis Mamet, 1939, Roy. Ent. Soc., London, Trans. 89: 583. TYPE-SPECIES : Mauritiaspis malloti Mamet, 1939, by original designation.

The author placed this genus in the Diaspinae, related to Parachionaspis MacGillivray. Balachowsky, 1954e: 172, accepted it as valid and assigned it to the Diaspidina, group II, chionaspiform.

Mediococcus Kiritshenko, 1936, Rev. d'Ent. de l'URSS (1935) 26: 144.

TYPE-SPECIES : Mediococcus circumscriptus Kiritshenko, 1936, by monotypy.

Borchsenius, 1948: 953, associated this genus with Centrococcus Borchsenius, Calyptococcus Borchsenius, and Coccura Sulc in the Coccurini, Pseudococcinae.

Megacanthaspis Takagi, 1960, Insecta Matsumurana 23: 68-69, nomen nudum; 1961, Insecta Matsumurana 24 : 97.

TYPE-SPECIES : Megacanthaspis actinodaphnes Takagi, 1961, by original designation and monotypy.

The author placed this genus in the Diaspidini and noted certain resemblances to Mercetaspis Gómez-Menor.

Megalecanium Hempel, 1920, Rev. Mus. Paulista [Sao Paulo] 12: 352,375 .

TYPE-SPECIES : Megalecanium testudinis Hempel, 1920, by original designation and monotypy.

The author placed this genus in the Coccinae (str.), similar to Mesolecanium Cockerell, but larger.

Megalocryptes Takahashi, 1942, Formosa Govt. Res. Inst. Dept. Agr. Rpt. 81: 20.

TYPE-SPECIES : Megalocryptes buteae Takahashi, 1942, by original designation.

The author placed this genus in the Coccinae (str.), resembling Cryptes Cockerell.

Megalodiaspis Paoli, 1916, Redia (1916) 11:256.

TYPE-SPECIES : Chionaspis (?) biclavis Comstock, 1883, by monotypy.

The author established this genus on a tentative basis, on the untenable assumption that elegans Leonardi (synonym of zamiae Morgan) was type-species of 
Howardia. Cockerell, 1896a: 256, had designated biclavis Comstock, 1883, as tspe-species of Howardia. Therefore Megalodiaspis Paoli is a synonym of Howardia Berlese and Leonardi because of Identity of properly designated typespecies.

Megalolecanium Lindinger, 1937, Ent. Jahrb. $46: 189$.

An emendation of Megalecanium Hempel.

Megalosaissetia Lindinger, 1937, Ent. Jahrb. 46:189.

An emendation of Megasaissetia Cockerell.

Megasaissetia Cockerell, 1901, Ent. Student 2:32.

TYPE-SPECIES : Lecanium (Saissetia) inflatum Cockerell and Parrott, 1899, by original designation and monotypy.

The author presented this as a subgenus of Saissetia Déplanche.

Megaspidiotus Brimblecombe, 1954, Queensland Jour. Agr. Sci. 11: 155 .

TYPE-SPECIES : Diaspis (?) fimbriata Maskell, 1893, by original designation and monotypy.

The author placed this genus in the Aspidiotini with closest relationship to 1spidiotus Bouché. Borchsenius and Williams, 1963, Brit. Mus. (Nat. Hist.) Ent. Bul. 13: 389, considered it distinct, belonging to a group of genera allied to Aspidiotus Bouché.

Melanaspis Cockerell, 1897, in Leonardi, Riv. di Patol. Veg. 5 : 375; Cockerell, 1897, U.S. Dept. Agr., Div. Ent., Tech. Ser. 6: 9, 13.

TYPE-SPECIES : Aspidiotus obscurus Comstock, 1881, by original designation.

The author presented this as a subgenus of Aspidiotus Bouché. Recent coccid workers have accepted it as a valid aspidiotine genus. See Ferris, 1941d : SIII328, SIII-347, for detailed discussion.

Melanespis Ali, 1962, Indian Jour. Sugarcane Res. \& Devlpmt. 6 : 74.

A lapsus for Melanaspis Cockerell.

Melzera Lindinger, 1937, Ent. Jahrb. 46 : 189.

An emendation of Melzeria Green.

Melzeria Green, 1930, Stettin. Ent. Ztg. 91:215-216.

TYPE-SPECIES: Melzeria horni Green, 1930, by original designation and monotypy.

The author assigned this genus provisionally to the Dactylopiinae.

Membranaria Brain, 1920, Bul. Ent. Res. 11:41.

TYPE-SPECIES : Membranaria pretoriae Brain, 1920, by original designation and monotypy.

The author placed this as a lecaniid genus, somewhat like Pulvinaria TargioniTozzetti. 
Mercetaspis Gómez-Menor, 1927, Eos 3 : 292.

TYPE-SPECIES: Mercetaspis sphaerocarpae Gómez-Menor, 1927, by original designation and monotypy.

The author placed this genus close to Adiscodiaspis Marchal. Balachowsky, $1954 \mathrm{e}: 126$, after a study of the types, assigned it to the Lepidosaphedina next to Nilotaspis Ferris.

Mesococcus Bekker-Migdisova, 1959, Akad. Nauk SSSR Paleontol. Inst. Materialy $3: 115$.

TYPE-SPECIES : Mesococcus asiatica Bekker-Migdisova, 1959, by original designation and monotypy.

The author erected this genus for a specimen of a pre-Cretaceous fossil insect from the Permian period of Central Asia, an oval insect with the appearance of a mealybug.

Mesolecanium Cockerell, 1902, Ann. and Mag. Nat. Hist. (ser. 7) 9 : 451.

TYPE-SPECIES : Lecanium nocturnum Cockerell and Parrott, 1899, by original designation.

The author placed this genus in the Lecaniinae and suggested a similarity to Calymnatus O. G. Costa.

Metacardia Ramakrishna Ayyar, 1926, Bombay Nat. Hist. Soc. Jour. $31: 451$.

A lapsus for Metatachardia Chamberlin.

Metaceronema Takahashi, 1955, Insecta Matsumurana 19: 27.

TYPE-SPECIES : Ceronema japonica Maskell, 1898, by original designation and monotypy.

The author noted the similarity of this genus to Ceronema Maskell and Mallococcus Maskell. Borchsenius, 1957: 91, placed it in the Filippiinae, Coccidae (str.).

Metadenopus Sulc, 1933, Acta Soc. Sci. Nat. Morav. 8 (12) (Signatura F76) : 1-2, 15.

TYPE-SPECIES : Metadenopus festucae Šulc, 1933, by monotypy.

The author placed this genus in the Coccinae (str.), not close to any known genus. Borchsenius, 1949: 185, assigned it to the Pseudococcidae, Pseudococcinae.

Metandaspis Williams, 1963, Brit. Mus. (Nat. Hist.) Ent. Bul. 15 : 28.

TYPE-SPECIES: Mytilaspis recurvata Froggatt, 1914, by original designation.

The author placed this genus close to Andaspis MacGillivray in the Lepidosaphes Shimer group of the Diaspidini. 
Metaspidiotus Takagi, 1957, Insecta Matsumurana 21: 35-36.

TYPE-SPECIES : Aspidiotus stauntoniae Takahashi, 1938, by original designation.

The author related this genus closely to Aspidiotus Bouché.

Metatachardia Chamberlin, 1923, Bul. Ent. Res. 14:172.

TYPE-SPECIES: Tachardia conchiferata Green, 1922, by original designation and monotypy.

The author presented this as a subgenus of Tachardia R. Blanchard and later, 1925, raised it to generic rank. He noted certain similarities that linked it with Tachardiella Cockerell. Balachowsky, 1950: 9, assigned it to the Lacciferinina.

Micrococcus Leonardi, 1907, Portici R. Scuola Super. di Agr. Lab. Zool. Gen. e Agr. Bol.1: 135 .

TYPE-SPECIES: Micrococcus silvestrii Leonardi, 1907, by designation of Sanders, $1909: 42$.

Lindinger, 1907, Ztschr. f. Wiss. Insektenbiol. 3: 159, objected to this name because of the existence of a bacterial genus with the same name. He was not supported in this objection by other authors. The genus was described in the Pseudococcinae. Ferris, 1921b: 60, associated it in a group of genera with Eriococcus Targioni-Tozzetti. Balachowsky, 1936c: 163, suggested a relation with Antonina Signoret but later, 1948b: 255, established the Micrococcini in the Lecaniinae for it. Ferris, $1957 \mathrm{~b}: 64$, and $1957 \mathrm{c}: 87$, rejected this action and maintained that the genus was definitely eriococcid, with which Hoy, 1963, New Zeal. Dept. Sci. and Indus. Res. Bul. 150: 11, concurred.

Microparlatoria Takahashi, 1956, Insecta Matsumurana 20: 26.

TYPE-SPECIES: Parlatoria itabicola Kuwana, 1931, by original designation and monotypy.

The author placed this genus close to Parlatoria Targioni-Tozzetti in the Diaspididae.

Mimeraspis Brimblecombe, 1957, Queensland Jour. Agr. Sci. 14: 261.

TYPE-SPECIES : Mimeraspis cuspilobis Brimblecombe, 1957, by original designation.

The author assigned this genus to the Aspidiotini and noted resemblance to Neomorgania MacGillivray and Pseudotargionia Lindinger.

Mimosicerya Cockerell, 1902, Entomologist 35 : 233.

TYPE-SPECIES : Icerya (Crypticerya) hempeli Cockerell, 1899, by monotypy.

Morrison, 1928: 104-108, placed this genus in the Coelostomidiini, Coelostomidiinae, Margarodidae, and noted a rery close relationship to Cryptokermes Hempel. 
Mimusaspis Mamet, 1942, Roy. Ent. Soc., London, Proc. Ser. B: Taxonomy 11: 37 .

TYPE-SPECIES: Lepidosaphes mimusopis Mamet, 1939, by original designation and monotypy.

The author placed this genus in the Diaspinae, somewhat related to Andaspis MacGillivray.

Mirococcopsis Borchsenius, 1948, Akad. Nauk USSR Dok. (n.s.) 63 : 582.

TYPE-SPECTES : Mirococcopsis rubidus Borchsenius, 1948, by original designation and monotypy.

The author placed this genus in the Pseudococcidae close to Mirococcus Borchsenius.

Mirococcus Borchsenius, 1947, Akad. Nauk Arm. SSR Dok. 7 : 141143.

TYPE-SPECIES : Phenacoccus inermis Hall, 1925, by original designation and monotypy.

The author placed this genus in the Pseudococcidae intermediate between Pseudococcus Westwood and Phenacoccus Cockerell.

Miscanthaspis Takagi, 1960, Insecta Matsumurana 23 : 68-69, nomen nudum; 1961, Insecta Matsumurana 24:69.

TYPE-SPECIES : Aulacaspis kuznoi Kuwana, 1932, by original designation.

The author placed this genus in the Phenacaspis Cooley and Cockerell group of the Diaspidini.

Miscanthicoccus Takahashi, 1958, Univ. Osaka (Prefecture) Bul. (ser. B) (1957) 7:6-7.

TYPE-SPECIES : Trionymus miscanthi Takahashi, 1928, by original designation and monotypy.

The author placed this genus near Neotrionymus Borchsenius and Paratrionymus Borchsenius in the Pseudococcidae.

Misericoccus Ferris, 1953, Atlas of the Scale Insects of North America $6: 384$.

TYPE-SPECIES: Ripersia arenaria Doane and Steinweden, 1927, by original designation and monotypy.

The author placed this genus close to Humococcus Ferris in the Pseudococcidae.

Misracoccus Rao, 1950, Roy. Ent. Soc., London, Proc., Ser. B : Taxonomy $19: 115$.

TYPE-SPECIES : Lophococcus convexus Morrison, 1920, by original designation.

This genus is placed in the Monophlebini, Monophlebinae, Margarodidae. 
Mitraspis Ferris, 1941, Atlas of the Scale Insects of North America (ser.3) [v. 3] : SIII-296.

TYPE-SPECIES: Mitraspis heresiarcha Ferris, 1941, by original designation and monotypy.

The author placed this genus in the Diaspidini, Diaspidinae. Balachowsky, 1954 e : 23 , assigned it to the Lepidosaphedina.

Mitrococcus Borchsenius, 1959, Ent. Obozr. 38:170.

TYPE-SPECIES : Mitrococcus celsus Borchsenius, 1959, by original designation and monotypy.

The author placed this genus in the Coccidae (str.) close to Idiosaissetia Brain and Inglisia Maskell.

Mitulaspidis MacGillivray, 1921, The Coccidae, p. 310.

TYPE-SPECIES: Chionaspis funtumiae Newstead, 1914, by original designation and monotypy.

This spelling appeared in the key where the generic characterization was presented. It has page priority over the spelling Mitulaspis on subsequent pages. The author assigned the genus to the Diaspidini. Balachowsky, 1954e:23, placed it in the Lepidosaphedina using the spelling Mitulaspis.

Mitulaspis MacGillirray, 1921, The Coccidae, pp. 3ǒ8, 491.

A lapsus for Mitulaspidis MacGillivray.

Mixaspis Takahashi, 1932, Soc. Trop. Agr. Jour. 4:46-47.

TYPE-SPECIES: Leucaspis bambusicola Takahashi, 1930, by original designation and monotypy.

The author placed this genus as intermediate between Leucaspis TargioniTozzetti and Parlatoria Targioni-Tozzetti. Balachowsky, 1953g: 812, placed it in the Leucaspidina.

Mixorthezia Morrison, 1926, Jour. Agr. Res. 30 : 151.

TYPE-SPECIES: Mixorthezia cubana Morrison, 1925, by original designation and monotypy.

See Morrison, 1925, 1952, for relationships.

Mizococcus Takahashi, 1928, Philippine Jour. Sci. 36 : 336.

TYPE-SPECIES : Mizococcus sacchari Takahashi, 1928, by original designation and monotypy.

Lindinger, 1932c: 203, placed this name in synonymy with Ripersia Signoret, and proposed a new specific name, takahashii, because of prior use of sacchari in Ripersia. He, 1943c: 250, replaced Ripersia with Tychea Koch. These actions are of doubtful validity. See under Tychea. 
Mohelnaspis Šle, 1937, Acta Soc. Sici. Nat. Morar. 10(11) (Nignatura F 100) : 29-30.

TYPE-SPECIES : Hohelnaspis moratica Sulc, 1937, by original designation aud monotypy.

The author described this genus as related in some degree to Bcrlesaspis MacGillivray. Ferris, 1938b: 57-58, considered the genus ralicl. Palachowskr, 1954 e: 152, accepted it and placed it in the Lepidosaphedina. He stated that the type-species was identical with massilensis Goux.

Mohelnia Sulc, 1941, Acta Soc. Sci. Nat. Morar. 13 (6) (Fignatura F 131) :1-2.

TYPE-SPECIES: Mohelnia festuceti Šule, 1941, by monotypy.

The author described this genus as phrlogenetically close to Scythia Kiritchenko, in the Coccidae (str.). Borchsenius, 1957: 40, 17s, placed the name in synonymy with Scythia.

Mollicoccus Tilliams, 1960, Brit. Mus. (Nat. Hist.) Ent. Bu1. 8: 40 T.

TYPE-SPECIES: Mollicoccus guadalcanalanus Williams, 1960, by original designation and monotypy.

The author placed this genus in the Phenacoccus Cockerell series of the Pseudococcidae.

Moluscococcus Hall, 1941, Ent. Soc. South. Africa Jour. 4: 236-237.

TYPE-SPECIES : Moluscococcus fibrillae Hall, 1941, by original designation and monotypy.

The author placed this genus in the Psendococcidae, related to Micrococcus Leonardi. Williams, 1958b: 4, assigned it to the Dactylopiidae as defined by Ferris, 1955a.

Monaonidiella MacGillirray, 1921, The Coccidae, p. 382.

TYPE-SPECIES : Aspidiotus ceratus Maskell, 1895, by original designation.

The author placed this genus in the Aspidiotini. Lindinger, 1937: 189, did not accept it as distinct from Aspiäiotus Bouché. Ferris, 1941a: 22. was uncertain as to its synonsmy with Aspiriella Leonardi. Brimblecombe, 1958: 85 and 1959: 140, accepted it and used it for Australian species.

Mongrovaspis Bodenheimer, 1951, Ent. Ber. 13 : 331 .

TYPE-SPECIES : Leucaspis quadrispinosa Green, 1934, by original designation.

The author placed this genus in the Diaspidinae, closely related to Leucaspis Targioni-Tozzetti. Balachowsky, 1953g: 813, 901-905, assigned it to his Parlatorini, Leucaspidina.

Monophlaebus Berlese and Leonardi, 1898, Ann. di 1 gr. Rome (ser. 2) : 14 .

A lapsus for Monophlebus Guérin-Méneville. 
Monophleba Latreille, 1829, in Cuvier, Le Règne Animal (ed. 2) 5: 233.

A lapsus for Monophlebus Guérin-Méneville. A male coccid was here characterized briefly without specific name.

Monophlebidus Morrison, 1927, Biol. Soc. Wash. Proc. 40:10t.

TYPE-SPECIES : MLnophlebidus indicus Morrison, 1927, by original designation and monotypy.

The author assigned this margarodid genus to the Monophlebinae, Monophlebini, group 1.

Monophleboides Morrison, 1927, Biol. Soc. Wash. Proc. 40 : 104.

TYPE-SPECIES : Monophlebus gymnocarpi Hall, 1926, by original designation and monotypy.

The author piaced this margarodid genus in the Monophlebinae, Monophlebini, group 1, closely related to and possibly zoologically identical with Palaeococcus Cockerell. See Morrison, 1928: 129, for discussion of relationships.

Monophlebulus Cockerell, 1902, Entomologist 35 : 233, 318.

TYPE-SPECIES: Monophlebus fuscus Maskell, 1893, by original designation and monotypy.

Morrison, 1928: 174, associated this margarodid genus with Nodulicoccus Morrison in the Monophlebinae, Monophlebulini.

Monophlebus Guérin-Méneville, 1827, in Dictionnaire Classique d'Histoire Naturelle, p. 99; Berthold, in Latreille, 1827, Natürliche Familien des Thierreiche, p. 428; Burmeister, 1835, Handb. der Ent. v. 2, abt. $1: 80$.

TYPE-SPECIES : Monophlebus atripennis Burmeister, 1835, by subsequent designation by Cockerell, 1902q : 232, 1902r : 317-318.

Although this name was credited to Leach in early works on coccids (Burmeister, 1835:80; Westwood, 1845:21; Sigmoret, 1875a:363), no recent coccid worker has reported its presence in any of Leach's work. Cockerell, 1902r:317, reported that an exhaustive search by C. H. Fermald had failed to locate it there. Monophlebus first appeared in an article by Guériu-Méneville, 1827: 99, and later in the same year in a German translation of Latreille's Familles Naturelles du Rìgne Animal. Two years later Latreille, 1829: 233, applied the name, Monophleba, to this same zoological unit. The genus acquired named species when Burmeister, 1835: 80, placed in it “M. atripennis Kl. $\hat{\sigma}$ " [actually Monophlebus atripennis Burmeister n. sp., 1835] and "M. fuscipennis n. sp." The first type fixation that has been found was by Cockerell, 1902q:232, 1902r: 317-318, where atripemis Burmeister, 1835, was selected as type and phases of the above situation reviewed.

Monophloebus Targioni-Tozzetti, 1867, Soc. Ital. di Sci. Nat. Mem. 3 (3). 18-19; 1868, (separate) Soc. Ital. di Sci. Nat. Atti 11:4; 1869, 11: 697 .

An emendation of Monophlebus Guérin-Méneville. 
Monoplhaebus Leonardi, 1901, Insetti Nocivi 4 : 386.

A lapsus for Monophlebus Guérin-Méneville.

Moraspis Hall, 1946, Roy. Ent. Soc., London, Trans. 97 : 525.

TYPE-SPECIES : Chionaspis euphorbiae Brain, 1919, by original designation and monotypy.

The author assigned this genus to the complex of genera of the Phenacaspis Cooley and Cockerell type of the Diaspidini. Balachowsky, 1954e:172, placed it in the Diaspidina, group II, chionaspiform.

Morganella Cockerell, 1897, U.S. Dept. Agr., Div. Ent., Tech. Ser. $6: 22$.

TYPE-SPECIES : (Aspidiotus (Morganella) maskelli Cockerell, 1897)=Aspidiotus longispinus Morgan, 1889, by monotypy.

The author presented this as a subgenus of Aspidiotus Bouché. It has been accepted by coccid workers as a valid aspidiotine genus. Balachowsky, 1951: 598, placed it in group I, Aspidiotina, Aspidiotini.

Morrisonella Hambleton, 1946, Rev. de Ent. [Rio de Janeiro] 17: 16.

TYPE-SPECIES : Morrisonella poensis Hambleton, 1946, by original designation.

This name was preoccupied in Mollusca and was replaced by Coccidella Hambleton. It is assigned to the Pseudococcidae, close to Ripersiella Tinsley, Rhizoecus Künckel and Neorhizoecus Hambleton.

Morrisonia Bodenheimer, 1951, Ent. Ber. 13 : 328 .

TYPE-SPECIES : Asterolecanium tena $x$ Bodenheimer, 1929, by original designation and monotypy.

This name is a synonym of Trachycoccus Borchsenius, 1950, because of community of type-species. Morrisonia was preoccupied in Lepidoptera, 1874, and in Crustacea, 1935.

Murataspis Balachowsky and Richardeau, 1942, Ent. Soc. de France Bul. 47:100.

TXPE-SPECIES : Hemiberlesia megaporus Balachowsky, by original designation.

The authors placed this genus in the Aspidiotinae. Balachowsky, 1951: 561, assigned it to the Aspidiotina close to Saharaspis Balachowsky.

Mutabilicoceus Williams, 1960, Brit. Mus. (Nat. Hist.) Ent. Bul. 8: 409.

TYPE-SPECIES : Farinococcus simmondsi Laing, 1924, by original designation.

The author assigned this genus to the Pseudococcidae.

Mycetaspis Cockerell, 1897, U.S. Dept. Agr., Div. Ent., Tech. Ser. $6: 8,13$.

TYPE-SPECIES : Aspidiotus personatus Comstock, 1883, by original designation and monotypy.

The author presented this as a subgenus of Aspidiotus Bouché. It was accepted as valid by Ferris, 1938, 1941d ; Lindinger, 1943b ; and Balachowsky, 1951. Bala- 
chowsky, 1958b: 205-207, placed it in the Aspidiotina, Aspidiotini, close to Melanaspis Cockerell.

Mycetococcus Ferris, 1918, Canad. Ent. 50:330.

TYPE-SPECIES : Cerococcus ehrhorni Cockerell, 18950 : 255, by original designation.

The author assigned this genus to the Asterolecaniini, Dactylopiinae.

Mycococcus Ferris, 1952, Microentomology $17: 2$.

TYPE-SPECIES : Mycococcus copernicae Ferris, 19ð2, by original designation.

The author placed this genus in the Asterolecaniidae.

Myrtophila Brimblecombe, 1957, Queensland Jour. $1 \mathrm{gr}$. Sci. 14: 264.

TYPE-SPECIES : Myrtophila curvata Brimblecombe, 1957, by original designation.

The author placed this genus in the Aspidiotini, related to Pseudotargionia Lindinger, Neomorgania MacGillivray, and Mimeraspis Brimblecombe.

Mytalaspis Cooke, 1881, Treatise on Insects Iniurious to Fruit and Fruit Trees of California, p. 37.

A lapsus for Mytilaspis Targioni-Tozzetti.

Mytiella Hoke, 1921, Ent. Soc. Amer. Ann. 14 : 341.

A lapsus for Mytilella Leonardi.

Mytilapsis Cockerell, 1897, Jamaica Bot. Dept. Bul. (n.s.) 4:108.

A lapsus for Mytilaspis Targioni-Tozzetti.

Mytilaspis Targioni-Tozzetti, 1868, (separate) Soc. Ital. di Sci. Nat. Atti 11:44; 1869, 11:737; Signoret, 1869, Soc. Ent. de France Ann. (1868) (ser.4) 8:841;1870, (ser.4) 10:91.

TYPE-SPECIES : (Coccus conchiformis Gmelin, 1798)=Coccus ulmi Linnaeus, 1758, by Signoret indication.

The proper orientation of Mytilaspis and its type-species remains a problem. Through the years it has been credited equally to Targioni-Tozzetti and Signoret. In our search of entomological literature we hare failed to find evidence to support the Signoret allegation of the publication of Mytilaspis by Targioni-Tozzetti and Signoret prior to the appearance of Lepidosaphes Shimer in January 1868. We conclude that Lepidosaphes has priority orer Mytilaspis. Mytilaspis appeared in a large number of coccid papers published prior to the Fernald Catalogue, 1903b, where it was placed as a synonyn of Lepidosaphes. Lindinger, 1936: 149, gave the first formal designation of a trpe-species of Mytilaspis naming linearis Targioni-Tozzetti. Ferris, 1937a: 4, selected Aspidiotus pomorum Bouché. Both of these names are generally accepted as synonyms of Coccus ulmi Linnaeus, 1758. 
Mytilella Leonardi, 1903, Portici R. Scuola Super. di Agr. Ann. (1904) (ser.2) $5: 20$.

TYPE-SPECIES : Mytilaspis carinata Cockerell, 1896, by monotypy.

This name was placed as a synonym of Opuntiaspis Cockerell by Lindinger, $1937: 190$; Ferris, 1936a : 25, and Balachowsky, 1954e : 94.

Mytilepiss Kuwana, 1917, A Check List of the Japanese Coccidae, p. 18.

A lapsus for Mytilaspis Targioni-Tozzetti.

Mytilicoccus von Schlechtendal, 1858, Hamburger Gart. u. Blumenzeitung 14: 408 (bottom of page).

A lapsus for Mytilococcus Amerling.

Mytillicoccus Amerling, 1858, Lotos 8: 29.

A lapsus for Mytilococcus Amerling. This spelling also appeared at top of page 408, von Schlechtendal, 1858.

Mytilococcus Amerling, 1858, Lotos 8: 101, 103.

TYPE-SPECIES: (Mytilococcus communis Amerling, 1858)=Coccus ulmi Linnaeus, 1758 (according to Lindinger, $1936: 148$ ), by subsequent designation of Lindinger.

Amerling presented the scientific name, "Mytilococcus communis mihi," with reference to illustrations of the scale covers but with no description of the coccid itself. Mytilococcus Amerling has priority over Lepidosaphes Shimer, 1868, and Mytilaspis Targioni-Tozzett1, 1868, and if this indication is sufficient to validate publication of genus and species, has validity as well. Lindinger, 1936: 148, 1937 : 190, held this to be the case and substituted Mytilococcus for Lepidosaphes, as did Silvestri, 1939: 803-811. However, most recent coccid workers (Ferris, Takahashi, Balachowsky, Borchsenius) have continued to use Lepidosaphes for this zoological unit. See under Lepidosaphes.

Myxilecanium MacGillivray, 1921, The Coccidae, pp. 178, 492.

A lapsus for Myzolecanium Beccari.

Myxolecanium Targioni-Tozzetti, 1877, Soc. Ent. Ital. Bul. $9: 317$.

A lapsus for Myzolecanium Beccari.

Myzolecanium Beccari, 1877, Melesia [Genova] 1 (2) : 190-191; Targioni-Tozzetti, 1877, Soc. Ent. Ital. Bul. 9: 317 [as Myxolecanium].

TYPE-SPECIES : Mỹolecanium kibarae Beccari, 1877, by monotypy.

Beccari's paper, which appeared earlier in the year than Targioni-Tozzetti's, contained a precise description and figures of the genus and species. Thus his names have nomenclatorial priority. 
Naiacoccus Green, 1919, Indian Mus. Rec. 18:117.

TYPE-SPECIES : Naiacoccus serpentinus Green, 1919, by original designation.

The author placed this genus in the Pseudococcinae near Erium Maskell. Ferris, $1950 \mathrm{~b}: 23$, associated it in a group including Amonostherium Morrison, Trabutina Marchal, and Nipaecoccus Šulc.

Naiococcus Lindinger, 1937, Ent. Jahrb. $46: 190$.

An emendation of Naiacoccus Green.

Najacoccus Bodenheimer, 1929, in Bodenheimer and Theodor, Ergebnisse der Sinai-Expedition 1927, p. 73.

An emendation of Naiacoccus Green.

Najococcus Bodenheimer, 1927, Inst. Agr. and Nat. Hist., Palestine Agr. Rec. 2:181.

A lapsus for Najacoccus Bodenheimer or Naiacoccus Lindinger.

Natalaspis MacGillivray, 1921, The Coccidae, p. 309.

TYPE-SPECIES: “Chionaspis simplex Brain," 1920 (actually C. simplex Green var. of Brain, 1920), by original designation and monotypy.

The author placed this genus in the Diaspidini. Ferris, 1938b: 71, made the name a synonym of Poliaspoides MacGillirray in the Odonaspidini. He considered the type-species of the two genera very close, if not identical. See Mamet, 1946 : 244 , for notes on possible identity of the type-species.

Natalensia Brain, 1915, Roy. Soc. So. Africa, Cape Torn, Trans. $5: 79,90$.

TYPE-SPECIES: Natalensia fulleri Brain, 1915, by original designation and monotypy.

The author placed this genus in the Pseudococcidae allied to Cryptoripersia Cockerell.

Natalensia Mamet, 1946, Mauritius Inst. Bul. 2 : 244.

A lapsus for Natalaspis MacGillivray.

Natalensis De Lotto, 19こ8, Brit. Mus. (Nat. Hist.) Ent. Bul. 7: 84.

A lapsus for Natalensia Brain.

Nautococcus Vayssière, 1939, Soc. Ent. de France Bul. 44: 124.

TYPE-SPECIES : Nautococcus schraderae Vayssière, 1939, by monotypy.

The author placed this genus in the Llareini, Monophlebinae, close to Llaveia Signoret, Llaviella Morrison, and Protortonia Townsend.

Neglectaspis Lindinger, 1937, Ent. Jahrb. $46: 190$.

TYPE-SPECIES : Aspidiotus unilobis Maskell, 1895, by original designation.

Ferris, $1937: 51,53,55$, placed this name as a ssnonvm of Chentraspis Leonardi because of community of type-species. Lindinger, 1943b:217, 222, disagreed, 
having designated extensus Maskell as type-species of Chentraspis, and maintained the validity of his genus. See under Chentraspis.

Nelaspis Hall, 1946, Roy. Ent. Soc., London, Trans. 97 : 499, 526.

TYPE-SPECIES: Chionaspis exalbida Cockerell, 1902, by original designation.

The author assigned this genus to the Diaspidini. Balachowsky, 1954e: 374, placed it in synonymy under Duplachionaspis MacGillivray. Williams, 1955: 140 , accepted this action.

Nemolecanium Borchsenius, 1955, Akad. Nauk SSSR Zool. Inst. Trudy 18: 289.

TYPE-SPECIES: Nemolecanium abietis Borchsenius, 1955, by original designation.

The author placed this genus in the Coccinae close to Parthenolecanium šulc.

Neoacanthococcus Borchsenius, 1948, Akad. Nauk SSSR Dok. (n.s.) $60: 502$.

TYPE-SPECIES: Neoacanthococcus tamaricicola Borchsenius, 1948, by original designation and monotypy.

The author placed this genus in the Pseudococcidae, subfamily Eriococcinae, close to Acanthococcus Signoret. Hoy, 1963, New Zeal. Dept. Sci. and Indus. Res. Bul. 150: 11, accepted it in the Eriococcidae on the basis of the published description of the genus.

Neoasterodiaspis Borchsenius, 1960, Akad. Nauk SSSR Zool. Inst. (n.s. 77) Fauna SSSR 8:207-208.

TYPE-SPECIES : Asterolecanium pasaniae Kuwana and Cockerell, 1909, by original designation.

The author placed this genus in the Asterolecaniinae, Asterolecaniidae, close to Asterodiaspis Signoret.

Neobernardia Cockerell, 1892, Insect Life $4: 333$.

TYPE-SPECIES : Chermes oleae Bernard, 1782, by substitution of Neobernardia for Bernardia Ashmead, 1891.

This was proposed as a substitute name for Bernardia Ashmead because the latter was preoccupied in botany. Neobernardia is accepted as a synonym of Saissetia Déplanche, 1859.

Neochionaspis Borchsenius, 1947, Akad. Nauk SSSR Dok. (n.s.) 58: 344.

TYPE-SPECIES : Neochionaspis kirgisica Borchsenius, 1947, by original designation and monotypy.

The author placed this genus close to Chionaspis Signoret and associated the type-species with Chionaspis asiatica Archangelskaia. Balachowsky, 1954e: 171, accepted it and placed it in his Diaspidina, chionaspiform. 
Neoclavaspis Brimblecombe, 1959, Queensland Jour. Agr. Sci. 16: 144.

TYPE-SPECIES : Neoclavaspis duplex Brimblecombe, 1959, by original designation and monotypy.

The author placed this genus in the Aspidiotini and noted some resemblance to Clavaspis MacGillivray and Quadraspidiotus MacGillivray.

Neoclavicoccus Cohic, 1959, Soc. Ent. de France Bul. 64 : 88.

TYPE-SPECIES : Neoclavicoccus ferrisi Cohic, 1959, by present designation.

The author placed this genus in the Pseudococcidae near Clavicoccus Ferris and described two new species without designation of either as trpe-species. Neoclavicoccus ferrisi has page priority.

Neocoelostoma Hempel, 1932, Rev. de Ent. [Śa Paulo] 2: 310-311.

TYPE-SPECIES : Neococlostoma xerophila Hempel, 1932, by original designation and monotypy.

The author placed this genus in the Coelostomidiinae, Margarodidae, close to Coelostomidia Cockerell.

Neof urcaspis Green, 1926, Bul. Ent. Res. $17: 61$.

TYPE-SPECIES : Neofurcaspis andamens is Green, 1926, by original designation and monotypy.

The author placed this genus close to Furcaspis Lindinger. Lindinger, 1937: 190, considered the name a synonym of Furcaspis. Ferris, 1935: 43, noted the necessity of a study of the Furcaspis series before conclusions on ralidity of the genus could be reached.

Neogreenia MacGillivray, 1921, The Coccidae, p. 474.

TYPE-SPECrES: Monophlebus zeylanicus Green, 1896, by substitution of Neogreenia for Paragreenia MacGillivray.

The author proposed this name to replace Paragreenia MacGillivray, preoccupied. Morrison, 1928: 65. discussed the type-species, questioned its association with Kuxania Cockerell, but did not assign it to a position in his system.

Neolecaniochiton Lindinger, 1937, Ent. Jahrb. 46:190.

An emendation of Neolecanochiton Hempel.

Neolecanium Parrott, 1901, in Cockerell and Parrott, Canad. Eint. $33: 58$.

TYPE-SPECIES : Lecanium imbricatum Cockerell, 1896, br original designation and monotypy.

This was proposed as a subgenus of Lecanium Burmeister. Steinweden, 1929: 227, considered it identical with Toumeyella Cockerell. 
Neolecanochiton Hempel, 1932, Rer. de Ent. [Sao Paulo] 2: 324.

TYPE-SPECIES : Neolecanochiton grevilleae Hempel, 1932, by original designation and monotypy.

The author placed this genus in the Lecaniinae with resemblances to Lecanochiton Maskell and Platinglisia Cockerell.

Neoleonardia MacGillivray, 1921, The Coccidae, p. 392.

TYPE-SPECIES : Aspidiotus extensus Maskell, 1895, by original designation and monotypy.

The author placed this genus in the Diaspidinae, Aspidiotini. Lindinger, 1937: 190, placed the name as a synonym of Chentraspis Leonardi. The genus was accepted as valid by Ferris, $1938: 43$, and Brimblecombe, 1953 : 161.

Neoleucaspis Green, 1926, Bul. Ent. Res. 17:63.

TYPE-SPECIES: Neoleucaspis parallela Green, 1926, by original designation and monotypy.

The author considered this genus allied to Leucaspis Targioni-Tozzetti. Lindinger, 1934: 26, and 1937: 190, placed the name as a synonym of Apteronidia Berlese. The genus was accepted as valid by Ferris, 1936a: 22, 25, and by Balachowsky, 1953g: 842, who assigned it to his Leucaspidina, Parlatorini.

Neomargania Balachowsky, 1951, Actualités Sci. et Indus., Ent. Appl. $1127: 677$.

A lapsus for Neomorgania MacGillivray.

Neomargarodes Green, 1914, Novitates Zool. $21: 263$.

TYPE-SPECIES : Neomargarodes erythrocephala Green, 1914, by original designation and monotypy.

The author established this genus for a male coccid from the Sahara. Marchal, 1922 : 1092, described all stages of a new species, trabuti, also from the Sahara, which he placed in this genus. Morrison, 1928: 79, redescribed the genus, associating it with Margarodes Guilding in the Margarodini.

Neomorgania MacGillivray, 1921, The Coccidae, pp. 394, 458.

TYPE-SPECIES: Pseudaonidia junctiloba Marlatt, 1908, by designation of Ferris, $1937 \mathrm{c}: 55$.

The author established this genus for three species: eucalypti Maskell, 1888, acaciae Morgan, 1899, and junctiloba Marlatt, 1908, without designation of a typespecies. Brimblecombe, 1954: 149-153, after a study of authentic material, concluded that the three represented a single species. In his opinion, this made eucalypti Maskell the type-species of Neomorgania, and the genus monotypic. Balachowsky, 1948b : 269, assigned the genus to the Pseudoaonidina, Aspidiotini.

Neoparlaspis Hempel, 1934, Rev. de Ent. [Sao Paulo] 4: 144; 1935, Arb. über Physiol. u. Angew. Ent. 2:57.

TYPE-SPECIES : Neoparlaspis myrciariae Hempel, 1934, by original designation and monotypy.

The author assigned this genus to the Diaspidinae, closest to the Parlatoriini. 
Neoparlatorea Lindinger, 1937, Ent. Jahrb. $46: 190$.

An emendation of Neoparlatoria Takahashi.

Neoparlatoria Takahashi, 1931, Soc. Trop. Agr. Jour. 3: 381-382.

TYPE-SPECIES : Neoparlatoria formosana Takahashi, 1931, by original designation and monotypy.

The author described this genus of the Diaspidini as related to Parlatoria Targioni-Tozzetti. Takagi, 1960:72-73, considered it very close to Cryptoparlatoria Lindinger, but the type-species validly distinct. Ferris, 1937d: 104, accepted it as valid.

Neopinnaspis McKenzie, 1949, Calif. Dept. Agr. Bul. 38: 123-124.

TYPE-SPECIES : Neopinnaspis harperi McKenzie, 1949, by monotypy.

The author assigned this genus to the Diaspidini, Diaspidinae, with resemblances to Pinnaspis Cockerell. Ferris, 1955b: 22, listed the name as a synonym of Africaspis Hall, but Borchsenius, 1959b: 1821, accepted the genus as valid and noted a closeness to Lepidosaphes Shimer and Andaspis MacGillivray.

Neoplatylecanium Takahashi, 1929, Formosa Govt. Res. Inst. Dept. Agr. Rpt. 40 : 53-54.

TYPE-SPECIES: Neoplatylecanium cinnamomi Takahashi, 1929, by original designation.

The author noted a relationship to Coccus Linnaeus, Platylecanium Cockerell and Robinson, and their allies.

Neopulvinaria Hadzibejli, 1955, Ent. Obozr. 34 : 232.

TYPE-SPECIES : Neopulvinaria imertina Hadzibejli, 1955, by original designation and monotypy.

The author placed this genus close to Rhizopulvinaria Borchsenius in the Pulvinariini, Coccinae.

Neorhizoecus Hambleton, 1946, Rev. de Ent. [Rio de Janeiro] 17: $40-41$.

TYPE-SPECIES : Rhizoecus coffeae Laing, 1925, by original designation.

Ferris, 1953a: 284, 386, and other recent coccid workers have accepted this as a valid pseudococcid genus.

Neorhyzoecus Hambleton, 1946, Rev. de Ent. [Rio de Janeiro] 17 : 2.

A lapsus for Neorhizoecus Hambleton.

Neoripersia Kanda, 1943, Kansai Ent. Soc. Trans. 12: 49-50.

TYPE-SPECIES: (Ripersia ogasawarensis Kanda, 1943 (not Kuwana 1909), by original designation and monotypy.

The author noted a close alliance of this pseudococcid genus with Ripersia Signoret. Ripersia ogasawarensis Kuwana, 1909, cited by Kanda as type-species was a misidentification. See Takahashi, 1958: 7, for details. 
Neoselenaspidus Mamet, 1958, Mus. Roy. du Congo Belge [Tervuren] (n.s.) Sci. Zool. 4:404-405.

TYPE-SPECIES: Selenaspidus silvaticus Lindinger, 1908, by original designation.

The author assigned this genus to the Aspidiotini closely allied to Selenaspidus Cockerell.

Neosignoretia MacGillivray, 1921, The Coccidae, p. 389.

TYPE-SPECIES : Aspidiotus yuccae Cockerell, 1896, by original designation.

The author placed this genus in the Aspidiotini, Aspidiotinae. Ferris, 1936a: 22, 26, disagreed; he considered the genus non-Aspidiotini. Lindinger, $1937: 190$, placed the name as a synonym of Pseudodiaspis Cockerell. Ferris, 1937 : SI-125, assigned Neosignoretia to synonymy with Situlaspis MacGillivray, and Hall, 1946a: 536, 547, discussed and accepted this placement.

Neosimmondsia Laing, 1930, Bul. Ent. Res. 21:19.

TYPE-SPECIES : Neosimmondsia hirsuta Laing, 1930, by original designation and monotypy.

The author assigned this genus to the Pseudococcus Westwood group of genera, near Farinococcus Morrison. Williams, 1960:389, 414, noted similarity to Cryptoripersia Cockerell and Mizococcus Takahashi, but placed it closest to Pilococcus Takahashi.

Neosteingelia Morrison, 1927, Biol. Soc. Wash. Proc. 40: 101.

TYPE-SPECIES : Neosteingelia texana Morrison, 1927, by original designation and monotypy.

The author placed this genus in the Margarodinae, Kuwaniini, related to Kuwania Cockerell.

Neotectococcus Hempel, 1937, Inst. Biol. [Sao Paulo] Arch. 8: 19.

TYPE-SPECIES : Neotectococcus Tenticularis Hempel, 1937, by original designation and monotypy.

The author assigned this genus to the "Apiomorphinae?". Ferris, 1957c: 87, and Hoy, 1963, New Zeal. Dept. Sci. and Indus. Res. Bul. 150:11, placed it in the Eriococcidae.

Neotrionymus Borchsenius, 1948, Akad. Nauk SSSR Dok. (n.s.) 63 : $581-582$.

TYPE-SPECIES : Neotrionymus monstatus Borchsenius, 1948, by original designation and monotypy.

The author described this genus in the Pseudococcidae, close to Pseudococcus Westwood, and, 1960e: 926, presented it in a key to genera related to Pseudantonina Green.

Nesococcus Ehrhorn, 1916, Hawaii. Ent. Soc. Proc. 3: 235, 238.

TYPE-SPECIES : Nesococcus pipturi Ehrhorn, 1916, by monotypy.

Zimmerman, 1948:274, 276, presented a redescription of this genus with placement in the Pseudococcidae near Trionymus Berg. 
Newstea dia Green, 1902, Ent. Monthly Mag. $38: 285$.

TrPE-SPECIES: Coccus floccosus De Geer, 1778, by original designation and monotsps.

This name replaced Douglasia Green. See Douglasia for details. Morrison. 1925, placed Nevsteadia in the Orthezinae, which he elerated to family rank, Ortheziidae, in 1952.

Newsteadiella MacGillirray, 1921, The Coccidae, pp. 71, 7s.

TrPE-SPECIES : Icerya formicarum Nerstead, 1897, by monotyps.

Rao, 1951: 40,54 , on the basis of examination of trpe and supplementary specimens, conciuded that the type-species is a normal Icerya rather widelr distributed in India, and placed the name in synonsmr with Icerya Signoret.

Nicholiella Ferris. 1941. Atlas of the Scale Insects of North America (ser. 3) [r. .3] : SIII-298.

TYPE-SPECIES: Nicholiella bumeliae Ferris, 1941, by original designation and monotyps.

The author placed this genus in the Diaspidini near Fissuraspis Ferris and Pelliculaspis Ferris. Brown, 1960:163, 165, 168, noted that the chromosome number of 8 in the trpe-species was suggestire of the lecanoid genetic system.

Niclularia Lindinger, 1957, Beitr. z. Ent. 7 : 549.

A lapsus for Tidularia Targioni-Tozzetti.

Nidularia Targioni-Tozzetti, 1868. (separate) Soc. Ital. di Sci. Nat. Atti 11: 34: 1869, 11: 727: Signoret. 1875. Soc. Ent. de France Ann. (ser. 5$) 5: 17$.

TYPE-SPECIES: Coccus pultinatus Plandhon. 1864, by subsequent restriction of Signoret, 1875 .

The author established this genus with a brief descriptire note and three associated species. Signoret, l.c., restricted the genus to pulvinatus, the second of these species, and it stood unquestioned as trpe-species of Nidularia for nearls 60 vears. Lindinger, 1933a: 107-108, asserted that the first species named br Targioni-Tozzetti. the species currentls called Gossyparia spuria (Moleer). must be accepted as trpe-species, and Nidularia must replace both Gossyparia Sisnoret and Eriococcus Targioni-Tozzetti of current usage. For the complex that had been known in literature as Tidularia, he proposed to substitute the name Querceticoccus. We beliere that the Signoret. 1875 , restriction of ViduIaria constituted an effectire trpe-species establishment and that Lindinger's subsequent changes mere not legitimate. On the basis of Marchal's redescription of the type-species, 1908: 259, it appears that Nidularia can assign close to Kermes Boitard.

\section{Nietnera Green, 1922, The Coccidae of Ceylor Part V, p. 454.}

TYPE-SPECIES : Nictnera pundaluoya Green, 1922, by original designation and naonotypy.

The author placed this genus in the Monophlebinae allied to Talkeriana Signoret. Morrison. 1928: 129, assigned it to group 1 of the Monophlebini and

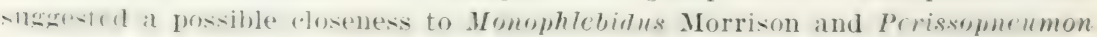
Newstead. 
Nigridiaspis Ferris, 1941, Atlas of the Scale Insects of North America (ser. 3) [v.3] : SIII-374.

TYPE-SPECIES: Nigridiaspis armigera Ferris, 1941, by original designation and monotypy.

The author placed this genus in the Aspidiotini, Diaspidinae.

Nikkoaspis Kuwana, 1928, Min. Agr. and Forestry, Dept. Agr. [Japan] Sci. Bul. 1:37.

TYPE-SPECIES: Nikkoaspis shiranensis Kuwana, 1928, by original designation and monotypy.

Takahashi, 1934: 15, considered this genus distinguishable from Tsukushiaspis Kuwana [synonym of Kuwanaspis MacGillivray]. Lindinger, 1937: 190, placed the name as a synonym of Kuwanaspis. Balachowsky, 1958b: 315, accepted it as valid and assigned it to his Parlatorina. Takagi, 1961: 4, 1961a: 78, 100, regarded it as distinct from Kuwanaspis and presented it in his key to Japanese genera of the Diaspidini.

Nilotaspis Ferris, 1941, Atlas of the Scale Insects of North America (ser. 3) [v. 3] : SIII-300.

TYPE-SPECIES: Lepidosaphes (Coccomytilus) halli Green, 1923, by original designation and monotypy.

The author placed this genus in the Diaspidini, Diaspidinae.

Nimbaspis Balachowsky, 1952, Rev. de Path. Veg. et d'Ent. Agr. de France $31: 125$.

TYPE-SPECIES : Nimbaspis mollardi Balachowsky, 1952, by original designation.

The author placed this genus in Diaspidinae, Odonaspidini, Rugaspidiotina, near Rugaspidiotus MacGillivray.

Nipaecoccus Sulc, 1945, Acta Soc. Sci. Nat. Morav. 17 (3) (Signatura F 177) :1.

TYPE-SPECIES: Dactylopius nipae Maskell, 1893, by original designation and monotypy.

The author assigned this genus to the Pseudococcidae. Borchsenius, 1948a: 953, placed it close to Phenacoccus Cockerell.

Nipponaclerda McConnell, 1954, Md. Agr. Expt. Sta. Bul. A-75: 107.

TYPE-SPECIES : Aclerda biuakocnsis Kuwana, 1907, by original designation and monotypy.

The author assigned this genus to the Aclerdidae.

Nipponorthezia Kuwana, 1916, Annot. Zool. Jap. 9 :150.

TYPE-SPECIES : Nipponorthezia ardisiae Kuwana, 1916, by monotypy.

The author assigned this genus to the Ortheziidae, closely allied to Orthesiola Šulc. See Morrison, 1952 : 72, for discussion of relationships. 
Niveaspis MacGillivray, 1921, The Coccidae, p. 276.

TYPE-SPECIES : Mytilaspis argentata Cockerell, 1898, by original designation and monotypy.

The author assigned this genus to the Diaspidinae, Lepidosaphini. Balachowsky, 1954e : 22-23, discussed it briefly and placed it in his Lepidosaphedina.

Nodulicoccus Morrison, 1923, U.S. Natl. Mus. Proc. 62, Art. 17 (No. 2463) : 19 .

TYPE-SPECIES : Monophlebus crawfordi var. levis Maskell, 1893, by monotypy.

The author assigned this genus to the Monophlebinae, Monophlebulini, associated with Monophlebulus Cockerell.

Noteococcus Hoy, 1962, New Zeal. Dept. Sci. and Indus. Res. Bul. $146: 164$.

TYPE-SPECIES: Eriococcus hoheriae Maskell, 1880, by original designation and monotypy. Hоу.

The author placed this genus in the Eriococcidae closely related to Phloeococcus

Nuculaspis Ferris, 1938, Microentomology $3: 45$, nomen nudum; 1938, Atlas of the Scale Insects of North America (ser. 2) [v. 2]: SII250 .

TYPE-SPECIES : Aspidiotus californicus Coleman, 1903, by original designation and monotypy.

The author placed this genus in the Diaspidinae, Aspidiotini. The type-species is identical with Aspidiotus pini Comstock, 1881, and has appeared under that name in much early literature. However, pini Comstock was preoccupied by Aspidiotus pini Bouché, 1851.

Nudachaspis MacGillivray, 1921, The Coccidae, p. 312.

TYPE-SPECIES: Chionaspis fodiens Green, 1898, by original designation and monotypy.

The author assigned this genus to the Diaspidinae, Diaspidini. Lindinger, 1937: 191, placed the name as a synonym of Ancepaspis Ferris. Ferris, 1937a: 4 , considered the genus valid as far as separation from Chionaspis Signoret was concerned.

Obluctaspis MacGillivray, 1921, The Coccidae, p. 311.

TYPE-SPECIES: Protodiaspis lobata Ferris, 1920, by original designation and monotypy.

The author placed this genus in the Diaspidini. Ferris, 1936a: 22, 26, and 1937: SI-99, and Lindinger, 1937: 191, assigned the name to synonymy with Protodiaspis Cockerell. 
Obtusaspis MacGillivray, 1921, The Coccidae, p. 393.

TYPE-SPECIES: Aspidiotus rhizophilus Newstead, 1920, by original designation and monotypy.

The author placed this genus in the Diaspidinae, Aspidiotini. Balachowsks, 1958b, 207-209, 230, 249, accepted the genus as ralid and assigned it to the Aspidiotini, Aspidiotina.

Ochyrocoris Menge, 1856, Progr. Petrischule Danzig, p. 17.

TYPE-SPECIES : Ochyrocoris electrina Menge, 1856, by monotypy.

Cockerell, 1896b : 326, stated that this is a fossil in amber, and probably an Orthezia Bosc d'Antic.

Octaspidiotus MacGillivray, 1921, The Coccidae, p. 387.

TYPE-SPECIES: Aspidiotus subrubescens Maskell, 1892, by original designation.

The author placed this genus in the Diaspidinae, Aspidiotini. Ferris, 1937c: 52,55 , accepted it as probably valid and, 1938a : SII-228, suggested that it might consolidate with Dynaspidiotus Thiem and Gerneck. Lindinger, 1937: 191, said "=Chrysomphalus." McKenzie, 1939: 56, considered that it derived from a common phylogenetic stock with Chrysomphalus Ashmead.

Octococcus Hall, 1939, Ent. Soc. South. Africa Jour. 2 : 93.

TYPE-SPECIES : Octococcus pentziae Hall, 1939, by original designation.

The author placed this genus in the Pseudococcidae and noted resemblances to Puto Signoret. Williams, 1958b: 6-8, corrected the description and considered the genus valid.

Odonaspis Leonardi, 1897, Riv. di Patol. Veg. (Nov. 1896-Feb. 1897) $5: 284$.

TYPE-SPECIES : Aspidiotus secretus Cockerell, 1896, by monotypy.

The author presented this as a new genus in a systematic table of genera of the Aspidioti. Soon thereafter, in published comments on a letter received from Cockerell regarding division of the genus Aspidiotus into subgenera, he noted that Cockerell had proposed a subgenus, Dycryptaspis, with the same trpe-species as Odonaspis Leonardi. Later, Leonardi, 1898b: 115, decided that Odonaspis was preoccupied by Odontaspis Agassiz, 1835, in fishes, and substituted spatheaspis. Lindinger, 1937: 184-185, agreed that Odonaspis was preoccupied because he considered that properly formed it should have been spelled Odontaspis, but held that its valid replacement was Dycryptaspis Cockerell. Other coccid workers (Ferris, Balachowsky, Borchsenius, Takagi) rejected Lindinger's conclusions and accepted Odonaspis as a valid genus assigned to the Odonaspidini.

Odontaspis Lindinger, 1937, Ent. Jahrb. $46: 191$.

The author considered Odonaspis Leonardi improperly formed and substituted this spelling which is a homonym of Odontaspis Agassiz, 1835. 
Olliffia Fuller, 1897, West. Austral. Bur. Agr. Jour. 4: 1345 (separate, Notes on Coccidae, p. 8), nomen nudum; 1899, Ent. Soc. London, Trans. 1899: 442.

TYPE-SPECIES : Olliffia eucalypti Fuller, 1899, by monotypy.

The author indicated a similarity of this genus to Eriococcus Targioni-Tozzetti. Ferris, $1957 \mathrm{~b}: 66$, noted that critical examination was necessary to determine its placement in the Eriococcidae. Hoy, 1963, New Zeal. Dept. Sci. and Indus. Res. Bul. $150: 11$, accepted this genus in the Eriococcidae on the basis of examination of a specimen labeled "type."

Olliffiella Cockerell, 1896, Science (n.s.) 4:300.

TYPE-SPECIES : Olliffiella cristicola Cockerell, 1896, by monotypy.

Ferris, 1957e : 87-88, and Hoy, 1963, New Zeal. Dept. Sci. and Indus. Res. Bul. 150 : 11, placed this genus in the Eriococcidae.

Onceropyga Ferris, 1955, Atlas of the Scale Insects of North America $7: 208$.

TYPE-SPECIES : Eriococcus neglectus Cockerell, 1895, by original designation.

The author assigned this genus to the Eriococcidae, a placement accepted by Hoy, 1963, New Zeal. Dept. Sci. and Indus. Res. Bul. $150: 11$. It is preoccupied by Onceropyga Turner, 1906, in the Lepidoptera.

Onicococcus Newstead, 1910, Bul. Ent. Res. 1: 186, nomen nudum.

TYPE-SPECIES : Onicococcus conchiformis Newstead ms., by monotypy.

Following his description of the insect Inglisia conchiformis sp. n., Newstead stated that he had given "the manuscript name Onicococcus conchiformis (gen. et sp. n.)" to material previously forwarded to the British Museum. Lindinger, 1937 : 191, said "=Cardiococcus."

Onychocephalus Newstead, Green, 1909, The Coccidae of Ceylon. Part IV, p. 282.

This appears to be a manuscript name, either an alternate or emendation of onicococcus Newstead ms. Green noted that the genus was doubtfully separable from Inglisia Maskell.

Oonidia Signoret, 1877, Soc. Ent. de France Ann. (1876) (ser. 5) 6: 669 .

A lapsus for Aonidia Targioni-Tozzetti.

Operculaspis Laing, 1925, Bul. Ent. Res. 16:62.

TYPE-SPECIES : Operculaspis crinitus Laing, 1925, by original designation and monotypy.

The author assigned this genus to the Aspidiotini. Ferris, 1937a: 3, 5, placed it in the Diaspidini.

Ophiscelis Signoret, 1869, Soc. Ent. de France $\Lambda n n$. (1868) (ser. 4) $8: 834$.

A lilpsus for Opisthoscolis Schrader. 
Ophistocelis Signoret, 1868, Soc. Ent. de France Ann. (ser. 4) 8: $525 ; 1877$ (1876) (ser. 5), 6: 597, footnote.

A lapsus for Opisthoscelis Schrader.

Ophistoscelis Signoret, 1869, Soc. Ent. de France Ann. (ser. 4) 9:100.

A lapsus for Opisthoscelis Schrader.

Opisthoscelis Schrader, 1863, Ent. Soc. N. So. Wales Trans. 1: 6.

TYPE-SPECIES : Opisthoscelis subrotunda Schrader, 1862, by subsequent designation by Fernald, 1903b : 46.

Ferris, $1957 \mathrm{~b}: 63-64$, presented a redescription of the genus but listed it with genera unplaceable in his classificatory scheme. Hoy, 1963, New Zeal. Dept. Sci. and Indus. Res. Bul. 150: 12, assigned it to the Eriococcidae.

Opliscelis Signoret, 1869, Soc. Ent. de France Ann. (1868) (ser. 4) $8: 855,872$.

A lapsus for Opisthoscelis Schrader.

Opuntiaspis Cockerell, 1898, Ann. and Mag. Nat. Hist. (ser. 7) 1:438.

TYPE-SPECIES : Mytilaspis philococcus Cockerell, 1893, by monotypy.

The author established this as a subgenus of Mytilaspis Targioni-Tozzetti. Ferris, 1937: SI-79; Lindinger, 1937: 190-191, and Balachowsky, 1954e: 26, 94-95, have accepted it as a valid genus and placed Mytilella Leonardi in synonymy.

Oracella Ferris, 1950, Atlas of the Scale Insects of North America (ser. 5) [v. 5]:22, 112 .

TYPE-SPECIES : Pseudococcus acutus Lobdell, 1930, by original designation and monotypy.

The describer placed this genus in the Pseudococcidae without more precise relation to other genera.

Orthezia Bosc d'Antic, 1784, Jour. de Phys. 24 (1) :171-173.

TYPE-SPECIES: (Orthezia characias Bose d'Antic, 1784)=Aphis urticae Linnaeus, 1758 , by monotypy.

This genus is placed in the Ortheziidae. See Morrison, 1925 and 1952, for detailed discussion of the genus.

Orthezinella Silvestri, 1924, R. Soc. Españ. Hist. Nat. Bol. 24: 170.

TYPE-SPECIES : Orthezinella hispanica Silvestri, 1924, by original designation.

Morrison, 1952: 72, assigned the type-species to Nipponorthezia Kuwana, making Orthezinclla a synonym of the latter; and placed ncotropicalis Silvestri, the other included species, in Mixorthezia Morrison. 
Ortheziola Sulc, 1895, K. Böhmisch. Gesell. der Wiss. Sitzber. (1894) no. $44: 1,5$.

TYPE-SPECIES : Ortheziola vejdovskyi Šulc, 1895, by monotypy.

The author placed this genus as closely allied to Orthezia Bosc d'Antic. Ghesquière, 1946: 236, designated Ortheziola signoreti (Haller) as the correct name for the type-species. See Morrison, 1952: 75, for details.

Ortheziopa Laing, 1925, Bul. Ent. Res. 15 : 383.

TYPE-SPECIES: Ortheziopa reynei Laing, 1925, by original designation and monotypy.

The author placed this genus as most closely allied to Ortheziola Sulc. Morrison, 1952: 2, considered it identical with Mixorthezia Morrison which was described earlier in 1925 than Ortheziopa.

Orthesiopoda Theeler, 1935, N.Y. Ent. Soc. Jour. 43 : 323.

A lapsus for Orthesiopa Laing. This name was presented in a quotation from letters of G. H. Bünzli.

Ortonia Signoret, 1875, Soc. Ent. de France Ann. (ser. 5) 5: 351.

TIPE-SPECIES : Ortonia uhleri Signoret, 1875, by subsequent designation of Cockerell, $1902 q$ : 232.

Morrison, 1928: 220, in error, listed 0 . bouvari Signoret as type-species, having orerlooked the Cockerell, 1902q : 232, designation of uhteri. Cockerell, 1899j : 259, haring discorered the preoccupation of this name by Ortonia Wood, 1869, and Ortonia Nicholson, 1873, placed the name in synonymy with Llaveia Signoret because he considered the two included species, bouvari and uhteri, to be congeneric with axin, the trpe-species of Llaveia. Fernald, 1903b:16, accepted this synonymy. Howerer, Cockerell's concept of axin was based on a species now assigned to another genus (see Morrison, 1927:108) and not on $L$. axin as recognized by Mexican (Bloede, 1884, Naturleza 6: [205]-210, and Dugés, 1884: Naturleza $6: 283,293,378$ ) and other writers. Morrison, 1928:189, considered bouvari congeneric and possibly identical with axin. The fragments of uhleri arailable for stude showed that it was not a characteristic member of Llaveia Signoret and probably would require a new genus to receire it. If this proves to be true, Ortonia would again stand as a zoologically ralid genus but a new name would be necessary for it.

Osiraspis Hall, 1923, Egypt Min. Agr. Tech. and Sci. Serr. Bul. 36: 24.

TYPE-SPECIES: Osiraspis baltcata Hall, 1923, by original designation and monotypy.

This genus has been accepted by recent coccid workers. Balachowsky, 1953g: 749-752, assigned it as an aberrant Odonaspidini, Rugaspidiotina. 
Oudablis Signoret, 1882, Soc. Ent. de France Ann. [Bul. Ent.] (1881) (ser.6) 1 : clvii.

TYPE-SPECIES: Coccus laurinus Boisduval, 1867 [emended to lauri by Signoret, $1875 \mathrm{~b}: 338$ ], by present designation.

Signoret substituted this name for his Boisduvalia, 1875, preoccupied by Boisduvalia Signoret, 1868, in Diptera. The genus mas based on the adult male character of two pairs of terminal waxy tassels in contrast to the single pair found in the males of Pseudococcus Westwood [Dactylopius of Signoret]. This characteristic applied to both of the named included species, lauri and quadricaudata, neither of which species have been recognized by modern European coccidologists. On our present limited knowledge of the classification of adult male coccids, it will assign to the Phenacoccus Cockerell series of genera rather than to the $P$ seudococcus Westwood series, where both Boisduvalia and Oudablis are presently assigned as synonyms. While Lindinger, 1912b: 360, has disposed of the originally included species by placing them as synonyms of Pseudococcus adonidum (Linnaeus) and $P$. citri (Risso) respectively, the reported presence of 8-segmented antennae does not necessarily bar them from the phenacoccine series, but does raise the question of whether or not the males and females as described actually belong together. There may be some chance to settle the question if these particular specimens are still present in the Signoret Collection.

Ourococcus Fuller, 1897, West. Austral. Bur. Agr. Jour. 4: 1346 (Notes on Coccidae, p. 10) ; 1899, Ent. Soc. London, Trans. (1899) p. 452 .

TYPE-SPECIES : Ourococcus eucalypti Fuller, 1897, by subsequent designation in the Fernald Catalogue, 1903b : 88.

Balachowsky, 1948b : 257, placed this genus in the Cylindrococcinae. Ferris, 1957b : 66, suggested the possibility that it might be included in the Eriococcidae. Hoy, 1963, New Zeal. Dept. Sci. and Indus. Res. Bul. 150: 12, assigned it to the Eriococcidae tentatively.

Ovaticoccus Kloet, 1944, Ent. Monthly Mag. 80 : 86.

TYPE-SPECIES : Coccus agavium Douglas, 1888, by substitution of Ovaticoccus for Gymnococcus Douglas.

The author proposed this name as a substitute for Gymnococcus, preoccupied in Protozoa by Zopf, 1884. See under Gymnococcus. Ferris, 1957c: 88, referred this genus to his Eriococcidae, an action accepted by Hoj, 1963, New Zeal. Dept. Sci. and Indus. Res. Bul. $150: 12$.

Ovatococcus Lindinger, 1958, Beitr. z. Ent. 8:368.

A misspelling or emendation of Ovaticoccus Kloet.

Palaeococcus Cockerell, 1894, Canad. Ent. 26 : 36.

TYPE-SPECIES: Monophlebus fuscipennis Burmeister, 1835, by subsequent designation of Cockerell, 1902q : 233.

Cockerell proposed this name to replace Leachia Signoret, 1875, preoccupied in Mollusca. Morrison, 1928: 128-129, placed this genus in the Monophlebini, most closely related to Monophleboides Morrison. 
Palacolecanium Lindinger, 1957, Beitr. z. Ent. 7 : $5 \pm 8$.

A lapsus for Palaeolecanium Šulc.

Palaeolecanium Sulc, 1908, Ent. Monthly Mag. 44: 36; 1932, Acta Soc. Sci. Nat. Morav. 7 (5) (Signatura F 57) :47-48.

TYPE-SPECIES : Lecanium bituberculatum Targioni-Tozzetti, 1868, by original designation and monotypy.

The author established this genus on characters of the male but later, 1932: 47, lowered it to subgeneric status. Lindinger, 1937: 192, accepted the genus but placed the type-species as a synonym of Coccus costatus Schrank. Borchsenius, $1957: 345$, 347 , rejected this action and considered the genus valid with typespecies as cited above.

Paleococcus Ferris, 1919, A Contribution to the Knowledge of the Coccidae of Southwestern United States. Stanford Univ. Pubs., Univ. Ser., p. 7.

A lapsus for Palaeococcus Cockerell. This spelling has been used by Morrison, 1921, Kuwana, 1922a, and others.

Palinaspis Ferris, 1941, Atlas of the Scale Insects of North America (ser.3) [v.3] : SIII-377.

TYPE-SPECIES : Targionia quohogiformis Merrill, 1923, by original designation.

The author assigned this genus to the Diaspidinae, Aspidiotini. Balachowsky, 1949c: 74, compared it with his Rungaspis and, 1959: 354, discussed its relationships.

Pallulaspis Ferris, 1937, Atlas of the Scale Insects of North America (ser. 1) [v. 1] : SI-82.

TYPE-SPECIES : Pallulaspis ephedrae Ferris, 1937, by original designation and monotypy.

The author placed this genus in the Diaspidini and noted a similarity to Velataspis Ferris. Balachowsky, 1954e: 25, 114, accepted it and assigned Coccomytilus retamae Hall as a second species. Takahashi, 1957b: 107, recorded it from Japan.

Palmaricoccus Stickney, 1984, U.S. Dept. Agr., Tech. Bul. 404: 49-51.

TYPE-SPECIES : Palmaricoceus attalcae Stickney, 1934, by original designation.

The author placed this genus in the Phoenicococeini. Ferris, 1952: 3, assigned the name as a synonym of Colobopyga Bréthes, 1912.

Palmaspis Bodenheimer, 1951, Ent. Ber. 13: 328.

TYPE-SPECIES : Asterolecanium phoenicis Rao, 1922, by original designation.

The author established this genus for Asterolecanium Group II of Russell, 1941: 9. Borchsenius, 1960d: 172, accepted it as restricted to the trpe-species and noted its closeness to Asterodiaspis Signoret. 
Palmicola Williams, 1960, Brit. Mus. (Nat. Hist.) Ent. Bul. 8: 415. TYPE-SPECIES : Ripersia palmarum Ehrhorn, 1916, by original designation.

Established for certain Pseudococcidae specific to the Palmaceae, the author, 1963, Entomologist 96:100-101, replaced it with Palmicultor because of preoccupation by Palmicola Mockford, 1955, in the Psocoptera.

Palmicultor Williams, 1963, Entomologist 96 : 100-101.

New name for Palmicola Williams.

Paloeolecanium Lindinger, 1958, Beitr. z. Ent. 8: 368.

A lapsus for Palaeolecanium Šulc.

Paludicoccus Ferris, 1918, Canad. Ent. $50: 324,327$.

TYPE-SPECIES : Pseudolecanium disticlium Kuwana, 1902, by original designation and monotypy.

Ferris, 1953a: 392, placed this genus in the Pseudococcidae. We think it may belong in the Antoninae although the anal ring is not typical.

Paracardiococcus Takahashi, 1935, Formosa Govt. Res. Inst. Dept. Agr. Rpt. 66: 6 .

TYPE-SPECIES : Paracardiococcus actinodaphnis Takahashi, 1935, by original designation and monotypy.

The describer noted differences from Cardiococcus Cockerell and Cryptostigma Ferris.

Parachionaspis MacGillivray, 1921, The Coccidae, p. 309.

TYPE-SPECIES : Chionaspis galliformens Green, 1899, by original designation and monotypy.

The author placed this genus in the Diaspidini. Ferris, 1937 a: 5, considered it valid. Lindinger, 1943b: 223, accepted the genus but emended the specific name to gallamformans. We reject this change.

Paracoccus Ezzat and McConnell, 1956, Md. Agr. Expt. Sta. Bul. A-84: $13,17$.

TYPE-SPECIES : Pseudococcus burnerae Brain, 1915, by original designation.

The authors placed this genus in the Pseudococcidae, Planococcini.

Paracoelostoma Morrison, 1927, Biol. Soc. Wash. Proc. 40: 102.

TYPE-SPECIES : Paracoelostoma peruviana Morrison, 1927, by original designation and monotypy.

The describer placed this genus in the Coelostomidiini, Margarodidae, related to Coelostomidia Cockerell, Ultracoelostoma Cockerell, Cryptokermes Hempel, and Mimosicerya Cockerell. 
Paraconchaspis Mamet, 1959, Inst. Sci. de Madagascar, Mém. (1959) (Sér. E. Ent.) 11:421.

TYPE-SPECIES: Paraconchaspis major Mamet, 1959, bJ original designation and monotypy.

The describer referred this genus to the Conchaspididae.

Paractenochiton Takahashi, 1942, Formosa Govt. Res. Inst. Dept. Agr. Rpt. 81: 28-29.

TYPE-SPECIES: Paractenochiton sutepensis Takahashi, 1942, by original designation and monotypy.

The author placed this genus in the Coccinae (str.).

Paradiaspis Lahille, 1919, Physis 4:595.

TYPE-SPECIES : Paradiaspis lizeriana Lahille, 1919, by monotypy.

Ferris, 1937d: 104, accepted this genus as valid and placed it in the Diaspidini.

Paradoxococcus McKenzie, 1962, Hilgardia 32 : 648-649.

TYPE-SPECIES: Paradoxococcus medanieli McKenzie, 1962, by original designation and monotypy.

The author referred this genus to the Pseudococcidae.

Paraepidiaspis Balachowsky, 1954, Inst. Pasteur [Paris] Mém. Sci., pp. 167, 230, 232.

TYPE-SPECTES : Diaspis (Epidiaspis) staticola Gómez-Menor, 1938, by original designation and monotypy.

The author placed this genus in his Diaspidina, group II, diaspiform.

Parafairmairea Lindinger, 1907, Ent. Wochenblatt 24:20.

An emendation of Parafairmairia Cockerell.

Parafairmairia Cockerell, 1899, Canad. Ent. 31: 332.

TYPE-SPECIES : Fairmairia bipartita Signoret, 1876 , by substitution of Parafairmairia for Fairmairia Signoret.

The author substituted this name for Fairmairia Signoret, preoccupied in Diptera, 1853. Steinweden, 1929: 229, associated this genus in a group with Exaerctopus Nerrstearl, Philephedra Cockerell, and Luzulaspis Cockerell. Goux, 1933: 123, considered it related to his Chlamydolecanium. Lindinger, 1932c: 204, placed Parafairmairia racilis Green, 1916, as a synonym of the trpe-species, an action rejected by Borchsenius, 1957: 132, and Schmutterer, 1952: 558, who accepted gracilis as distinct and valid.

Parafiorinia MacGillivray, 1921, The Coccidae, p. 372.

TYPE-SPECIES : Fiorinia rubra Maskell, 1894, by original designation.

This genus was placed by its author in the Diaspidinae, Fioriniini. Lindinger, 1937 : 192, said : "=Anamefiorinia Leon." 
Paragadaspis Kaussari and Balachowsky, 1954, Soc. Fouad Ier Ent. Bul. $38: 161$.

TYPE-SPECIES: Paragadaspis sarkissiani Kaussari and Balachowsky, 1954, by original designation and monotypy.

The authors placed this genus in the Diaspidini, Diaspidina with all the general characters of Gadaspis Hall.

Paragreenia MacGillivray, 1921, The Coccidae, pp. 78, 474.

TYPE-SPECIES: Monophlebus zeylanicus Green, 1896, by monotypy.

The author substituted Neogreenia for this generic name, preoccupied in Arachnida in 1907.

Parakuwania Borchsenius, 1960, Zool. Zhur. 39 : 144.

TYPE-SPECIES: Kuwania betulae Borchsenius, 1938, by original designation and monotypy.

The author assigned this genus close to Kuwania Cockerell of the Kuwaniini, Margarodinae.

Paralecanium Cockerell, 1899, in Cockerell and Parrott, Industrialist $25: 227$.

TYPE-SPECIES : Lecanium frenchii Maskell, 1891, by original designation.

The author placed this genus as "allied to Calymnatus." Lindinger, 1937 : 181, said : "=Coccus L." Steinweden, 1929: 206, and other workers recognized it as valid.

Paralecanopsis Bodenheimer, 1951, Ent. Ber. 13: 329; 1953, Istanbul

Facult. des Sci. Rev., Ser. B, 18:109.

TYPE-SPECIES: Paralecanopsis turcica Bodenheimer, 1951, by original designation and monotypy.

The author placed this genus close to Lecanopsis Targioni-Tozzetti.

Paralepidosaphes Borchsenius, 1962, Ent. Obozr. 41: 863-864.

TYPE-SPECIES: Paralepidosaphes coreana Borchsenius, 1962, by original designation.

The author placed this genus close to Lepidosaphes Shimer.

Paraleucaspis Mamet, 1954, Inst. Sci. de Madagascar, Mém. (1953), (Sér. E. Ent.) $4: 70-71$.

TYPE-SPECIES : Pseudoleucaspis halli Mamet, 1940, by original designation.

The author noted resemblances to Pseudoleucaspis Mamet and Emmereziaspis Mamet. Balachowsky, 1958b; 335, placed the genus in his Leucaspidina.

Paramyrmococcus Takahashi, 1941, Tenthredo $3: 204$.

TYPE-SPECIES : Paramyrmococcus chiengraiensis Takahashi, 1941, by original designation and monotypy.

The author placed this genus in the Pseudococcidae closely related to Allomyrmococcus Takahashi. 
Paranewstea dia MacGillivray, 1921, The Coccidae, p. 391.

TYPE-SPECIES : Aspidiotus maculatus Newstead, 1896, by original designation and monotypy.

The author placed this genus in the Diaspidinae, Aspidiotini.

Paraonidea MacGillivray, 1921, The Coccidae, p. 394.

A lapsus for Paraonidia MacGillivray.

Paraonidia MacGillivray, 1921, The Coccidae, p. 394.

TYPE-SPECIES: Aspidiotus (Chrysomphalus) malleolus Green, 1905, by original designation and monotypy.

Balachowsky, 1948b: 269, placed this genus in his Pseudoaonidina. Ferris, 1938: 43, noted the necessity for study of the Pseudaonidia group of genera to confirm the validity of Paraonidia.

Paraonidiella MacGillivray, 1921, The Coccidae, p. 392.

TYPE-SPECIES: Aspidiotus cladii Maskell, 1891, by original designation and monotypy.

The author placed this genus in the Diaspidinae, Aspidiotini. Laing, 1929: 26, and Lindinger, $1937:$ 192, considered the name a synonym of Furcaspis Lindinger. Ferris, 1938: 43, noted the necessity of restudy of the Furcaspis group of genera in order to reach a decision on the status of Paraonidiella.

Paraparlagena Mamet, 1959, Inst. Sci. de Madagascar, Mém. (1959) (Sér. E. Ent.) 11:452.

TYPE-SPECIES : Paraparlagena ifanadiana Mamet, 1959, by original designation and monotypy.

The author placed this genus in the Diaspidinae near Parlagena McKenzie.

Parapedronia Balachowsky, 1953, Soc. des Sci. Nat. du Maroc. Bul. (1951) 31 (semes. 2) : 283.

TYPE-SPECIES: Pedronia spinigera Goux, 1937, by original designation and monotypy.

The author placed this genus in the Psendococcidae near Pedronia Green. Danzig, 1960 : 178, placed the name in synonymy with Spinococcus Borchsenino

Paraputo Laing, 1929, Ann. and Mag. Nat. Hist. (ser. 10) 4: 473.

TYPE-SPECIES: Paraputo ritchiei Laing, 1929, by original designation and monotypy.

The anthor placed this genus in the pseudococcine series. Williams, 19.58: 217219, placed the name of the type-species as a synonym of Paraputo [Ripersia] anomala (Newstead). 
Pararhizoecus Goux, 1941, [Marseille] Mus. d'Hist. Nat. Bul. [1941] (3) : 197.

TYPE-SPECIES : Rhizoecus (Pararhizoecus) petiti Goux, 1941, by original designation and monotypy.

The author placed this genus close to Rhizoecus Künckel d'Herculais in the Pseudococcidae. We consider the name a synonym of Ripersiella Tinsley.

Parasaissetia Takahashi, 1955, Insecta Matsumurana 19:26.

TYPE-SPECLES: Saissetia nigra Nietner, 1861, by original designation.

The author noted that this genus is more closely related to Lecanium Burmeister than to Pulvinaria Targioni-Tozzetti. Lindinger, 1957: 551, rejected the genus as identical with Saissetia Déplanche.

Paraselenaspidus Mamet, 1958, Mus. Roy. du Congo Belge [Terruren] Ann. (n. s.) Sci. Zool. 4:418, 420.

TYPE-SPECIES : Sclenaspidus madagascariensis Mamet, 1953, by original designation.

The author placed this genus in the Aspidiotini, closely allied with Selcnaspidus Cockerell.

Paraspidiotus Thiem and Gerneck, 1934, Arb. über Physiol. u. Angew. Ent. 1:131, 230-231.

TYPE-SPECIES : Aspidiotus viticola Leonardi, 1913, by original designation and monotypy.

Lindinger, $1937: 192$, said "=Aspidiotus" and, $1957: 551$, placed the type-species in synonymy with Aspidiotus labiatarum Marchal. Ferris, 1941e: 41, suggested that the type-species might belong in Diaspidiotus Berlese and Leonardi.

Paratachardina Balachowsky, 1950, Eos $26: 8$.

TYPE-SPECIES: Carteria decorella Maskell, 1892, by original designation and monotypy.

The author placed this genus in the Tachardini, Tachardinina.

Paratrionymus Borchsenius, 1948, Akad. Nauk SSSR Dok. (n. s.) $63: 582$.

TYPE-SPECIES : Ripersia halocharis Kiritchenko, 1932, by original designation and monotypy.

The author placed this genus in the Pseudococcidae close to Neotrionymus Borchsenius.

Parischnaspis MacGillivray, 1921, The Coccidae, 276.

TYPE-SPECIES: Ischnaspis spathulata Lindinger, 1911, by original designation and monotypy.

The author placed this genus in the Diaspidinae, Lepidosaphini. 


\section{Misc. PUBLICATION 1015 , U.S. DEPT. OF AGRICULTURE}

Parlagena McKenzie, 1945, Microentomology 10 : 81-82.

TYPE-SPECIES: (Parlagena inops MacKenzie, 1945)=Gymnaspis buxi Takahashi, 1936, by original designation and monotypy.

The author placed this genus in the parlatorine series allied to Parlatoria Targioni-Tozzetti. Balachowsky, 1950a: 17, reported the identity of the typespecies with buxi Takahashi, 1936, and, 1953g: 833, assigned the genus to his Parlatorini, Parlatorina.

Parlaspis McKenzie, 1945, Microentomology 10 : 82.

TYPE-SPECIES : Parlatoria (Websteriella) papillosa Green, 1919, by original designation and monotypy.

The author placed this genus in the Diaspidini, noting a relation to Parlatoria Targioni-Tozzetti. Balachowsky, 1958b: 315, assigned it to his Parlatorina. [Misspelled the type-species papillotae.]

Parlatorea Lindinger, 1905, Insekten Börse 22:131.

An emendation of Parlatoria Targioni-Tozzetti. Brain, 1919: 212, 214, and Gómez-Menor, 1937: 43, accepted this spelling but most modern coccid workers (Ferris, Balachowsky, Borchsenius, Morrison, McKenzie) have rejected it.

Parlatoreopsis Lindinger, 1912, Die Schildläuse, pp. 14, 191.

TYPE-SPECIES : Chionaspis longispina Newstead, 1911, by monotypy.

Coccid workers have accepted this as a valid genus but there has been some uncertainty in regard to the included species. Balachowsky, 1953g: 828-829, discussed this situation and concluded that longispina Newstead and chinensis Marlatt are distinct although they were placed as synonyms by Lindinger, 1937, Ferris, 1942, and McKenzie, 1945. He also placed perplexa McKenzie in synonymy with longispina Newstead; both species were described from Egypt. Borchsenius, 1950b: 172, credited the generic name to MacGillirray, 1921: 309, citing the Lindinger, 1912b: 385, presentation as a nomen nudum. We do not agree with this interpretation of the Lindinger presentation.

Parlatoria Targioni-Tozzetti, 1868, (separate) Soc. Ital. di Sci. Nat. Atti 11:42; 1869, 11: 735; Signoret, 1869, Soc. Ent. de France Ann. (ser.4) $9: 99,450$.

TYPE-SPECIES : Aspidiotus proteus Curtis, 1843, by subsequent designation of Leonardi, 1899a : 208.

Leonardi wrote: "But as Targioni, in 1868, established the genus Parlatoria first for his $P$. orbicularis, that is, the Diaspis parlatoris of his Studi sulle cocciniglie of the previous year and which he, himself, considered a synonym of $P$. proteus Curtis, and only secondarily joined with it Coccus zizyphi Lucas, thus I, to give a name to the two subgenera, as I intend to do, will call Parlatoria (s. str.) the subgenus of which the type is P. proteus and . ..." Fernald, 1903b: 318, and Ferris, 1936a: 22, incorrectly listed P. lucasii (zizyphus) as typespecies.

Parlatorie Šulc, 1936, Českoslov. Zool. Společ. Věst. (1935) 3:66.

A lapsus for Parlatoria Targioni-Tozzetti. 
Paroudables Hadzibejli, 1959, Akad. Nauk Gruz. SSR Soobshch. 23 : 575 .

A lapsus for Paroudablis Cockerell.

Paroudablis Cockerell, 1900, Entomologist $33: 87$.

TYPE-SPECIES : Boisduvatia piceae Löw, 1883, by subsequent designation of Fernald, $1903 b: 89$.

This genus was separated from Phenacoccus Cockerell on the character of four caudal filaments in the adult male. Borchsenius, 1949: 237, recognized the genus as valid but Ferris, 1950b: 120, placed it in synonymy with Phenacoccus Cockerell.

Parrotia Gómez-Menor, 1954, Eos $30: 141$.

The author proposed Parrotia as a subgenus of Gymnococcus Douglas for two described American species whose names he did not include. We believe the name has no standing because it does not fulfill the requirements of Article 13 (b) of the 1961 Code. Further, it is preoccupied by Parrotia Kieffer, 1924, in the Diptera, according to Neave, 1940, Nomen. Zool. III : 619.

Parrottia MacGillivray, 1921, The Coccidae, p. 394.

TYPE-SPECIES: Aspidiotus moorei Green, 1896, by original designation and monotypy.

The author placed this genus in the Diaspidinae, Aspidiotini. Balachowsky, 1948b : 269, assigned it to his Pseudoaonidina. Ferris, 1938: 43, noted the necessity of a study of the Pseudaonidia Cockerell series to establish its status.

Partargionia MacGillivray, 1921, The Coccidae, p. 394.

TYPE-SPECIES : Aspidiotus artocarpi Green, 1896, by original designation and monotypy.

The author placed this genus in the Diaspidinae, Aspidiotini. Ferris, 1937d: 106, discussed the genus (listed in error as Protargionia) and, 1943a: 85, concluded that it was definitely not a Targionia Signoret. Takhashi, 1939d: 344, and Williams, 1957a: 33-34, placed the name as a synonym of Semelaspidus MacGillivray.

Parthenolecanium Sulc, 1908, Ent. Monthly Mag. 44 : 36 ; 1932, Acta Soc. Sci. Nat. Morav. 7 (5) (Signatura F 57) : 64.

TYPE-SPECIES: (Lecanium coryli Šulc, 1908, nec Linné, 1758)=Lecanium corni Bouché, 1844, by original designation.

The author proposed this as one of four genera into which he divided the genus Lecanium (sensu Signoret), separating it as parthenogenetic and without males, from the other three genera, which he differentiated on characters of the males. He set as type-species, coryli L., 1758, and included persicae Fabricius, 1776, suggesting that the two species were possibly identical. In 1932: 47, he lowered the status of these genera to that of subgenera and described the male scale and male characters of Parthenolecanium. Kawecki, 1951-1961, in his works on the genus Lecanium, accepted this concent and action. Other workers have not agreed. Lindinger, 1937: 192, placed this name in synonymy with 
Palaeolecanium Šulc. Borchsenius, 1957: 347, accepted Parthenolecanium as valid and cited as type-species, Lecanium corni Bouché, 1844, with Lecanium coryli Šule, 1908 , a synonym.

Paulianodes Mamet, 1954, Inst. Sci. de Madagascar, Mém. (1953) (Sér. E. Ent.) 4:10, 29-30.

TYPE-SPECIES : Puulianodes madecassus Mamet, 1954, by original designation and monotypy.

The author placed this genus in the Pseudococcidae, related to Kuwania Cockerell and allied genera.

Pedrococcus Mamet, 1942, Roy. Ent. Soc., London, Proc. Ser. B : Taxonomy $11: 79$.

TYPE-SPECIES : Pedronia greeni Mamet, 1937, by original designation.

The author placed this genus in the Pseudococcidae near Pedronia Green. Balachowsky, 1953: 282, 284, considered it close to Synacanthococcus Morrison.

Pedronia Green, 1922, The Coccidae of Ceylon. Part V, p. 364.

TYPE-SPECIES : Pedronia strobilanthis Green, 1922, by original designation and monotypy.

The author placed this genus in the Pseudococcidae. Lindinger, 1933a: 108, considered the name a synonym of Nidularia Targioni-Tozzetti [Eriococcus auct.]. Recent workers have considered it a valid genus.

Pedroniopsis Green, 1926, Bul. Ent. Res. $17: 59$.

TYPE-SPECIES : Pedroniopsis beesoni Green, 1926, by original designation and monotypy.

The author placed this genus in the Eriococcinae, though superficially resembling Pedronia Green. Hoy, 1963, New Zeal. Dept. Sci and Indus. Res. Bul. 150: 12 , accepted the genus in the Eriococcidae.

Pela Targioni-Tozzetti, 1866, R. Accad. dei Georg. Atti (n. s.) 13: 140.

TYPE-SPECIES: Pela cerifera Targioni-Tozzetti, 1866, by original indication and monotypy.

This was proposed as a substitute name for Coccus pela Westwood, 1853. It is an isogenotypic synonym of Ericerus Guérin-Méneville.

Peliococcopsis Borchsenius, 1948, Akad. Nauk SSSR Dok. (n. s.) 61: 954 .

TYPE-SPEctes: Phenacoccus caucasicus Borchsenius, 1939, by original designation and monotypy.

'The author placed this genus in the Phenacoccus Cockerell series of the Pseudococcidae near Peliococcus Borchsenius. 
Peliococcus Borchsenius, 1948, Akad. Nauk SSSR Dok. (n. s.) 61: 954.

TYPE-SPECIES : Phenacoccus chersonensis Kiritchenko, 1936, by original designation and monotypy.

The author placed this genus in the Phenacoccus series of the Pseudococcidae close to Phenacoccus Cockerell.

Pelliculaspis Ferris, 1941, Atlas of the Scale Insects of North America (ser. 3) [v. 3] : SIII-309.

TYPE-SPECIES : Pelliculaspis pellita Ferris, 1941, by original designation.

The author placed this genus in the Diaspidinae, Diaspidini. Lindinger, 1957: 551 , transferred the two included species, pellita Ferris and durapyga Ferris, to Anamefiorinia Leonardi.

Pelomphala MacGillivray, 1921, The Coccidae, p. 292.

TYPE-SPECIES: Aspidiotus (Chrysomphalus) lilacinus Cockerell, 1898, by original designation.

The author placed this genus in the Aspidiotini. Ferris, 1937 : 52, 54, and Silvestri, 1939: 849, considered the genus valid. However, Lindinger, 1937: 192, Ferris, 1941d: SIII-347, and Balachowsky, 1951: 578, placed the name as a synonym of Melanaspis Cockerell.

Penaspis Dale, 1960, WVest Samoa Dept. Agr., Forests, and Fisheries Inform. Cir. 4: 12 .

A lapsus for Pinnaspis Cockerell.

Pendularia J. P. da Fonseca, 1927, Chacaras e Quintaes 36: 268.

TYPE-SPECIEs : Pendularia pendens J. P. da Fonseca, 1927, by original designation and monotypy.

The author placed this genus in the Lecaniinae, allied to Pulvinaria TargioniTozzetti, Protopulvinaria Cockerell, Takahashia Cockerell, and Pulvinella Hempel. Costa Lima, 1930a: 87, placed the name as a synonym of Takahashia.

Pergandiella Cockerell, 1899, Acad. Nat. Sci. Phila. Proc. [1899]: 266.

TYPE-SPECIES: Pergandiella americana Cockerell, 1899, by original designation.

This name is currently accepted as a synonym of Trionymus Berg.

Pergrothula Ferris, 1950, Atlas of the Scale Insects of North America (ser. 5) [v. 5]:251.

A lapsus for Bergrothula Strand. 
Pericerya Silvestri, 1939, Compendio di Ent. Appl. Parte Spec. 1(2): 648-649.

TYPE-SPECIES : Icerya purchasi Maskell, 1879, by monotypy.

The author placed this genus in the Monophlebini, differentiated from Icerya Signoret by having only two pairs of abdominal spiracles in the adult female. The name has received only slight acceptance in entomological literature.

Perilecanium J. P. da Fonseca, 1962, Inst. Biol. [São Paulo] Arch. 29: [13]-15.

TYPE-SPECIES: Lecanium transparens Hempel, 1937, by original designation.

The author placed this genus in the Lecaniidae close to Lecanium Burmeister.

Perissopneumon Newstead, 1900, Ent. Monthly Mag. 36: 250.

TYPE-SPECIES : Perissopneumon ferox Newstead, 1900, by monotypy.

The author characterized this genus as strictly monophlebid. Morrison, 1928: 135 , placed it in his group 2 of the Monophlebini.

Persiocecis Amyot, 1847, Soc. Ent. de France Ann. (ser. 2) 5: 501.

A uninominal designation to replace a generic and specific name for the insect involved, [Lecanium] persicae Fabricius. It is without generic validity.

Persiotrocha Amyot, 1847, Soc. Ent. de France Ann. (ser. 2) 5: 501.

A uninominal designation to replace a generic and specific name for the insect involved, [Lecanium] prunastri (Fonscolombe). It is without generic validity.

Peryceria Gómez-Menor, 1960, Eos 36:204.

A lapsus for Pericerya Silvestri.

Peukinococcus Sulc, 1944, Acta Soc. Sci. Nat. Morav. (Signatura F 169) $16(11): 2$.

TXPE-SPECIES : Boisduvalia piceae Löw, 1883, by monotypy.

This is an isogenotypic synonym of Paroudablis Cockerell. Ferris, 1950b : 120, and Lindinger, 1957 : 551, considered it a synonym of Phenacoccus Cockerell.

Phaenococcus Lindinger, 1937, Ent. Jahrb. 46:192.

An emendation of Phenacoccus Cockerell not generally accepted.

Phaulaspis Leonardi, 1897, Riv. di Patol. Veg. (Nov. 1896-Feb. 1897) $5: 284$.

TYPE-SPECIES : Aspidiotus hakeae Maskell, 1896, by monotypy.

The author placed this geuus in his Aspidioti. Morrison and Morrison, 1922: 89 ; Lindinger, 1937: 183, 192 ; and Ferris, $1937 \mathrm{c}: 52-53$, accepted it as valid.

Phaulomytilus Leonardi, 1898, Riv. di Patol. Veg. (1897) 6:45(205)$46(206)$.

TYPE-SPECIES : Mytilaspis striata Maskell, 1895, by monotypy.

The author presented this genus as a subdivision of Mytilaspis TargioniTozzetti. Morrison and Morrison, 1922: 96, 99, redescribed the type-species 
and considered the morphological modification sufficient to separate the genus widely from Lepidosaphes Shimer. Lindinger, 1937: 192, placed the name as a synonym of Mytilococcus Amerling [Lepidosaphes]. Ferris, 1938: 37, and Balachowsky, 1954e: 23 , accepted the genus as valid, the latter assigning it to his Lepidosaphedina.

Phenacaspis Cooley and Cockerell, 1899, in Cockerell, Ill. Nat. Hist. Survey Bul. 5 : 398 ; Cooley, 1903, Canad. Ent. 35 : 48.

TYPE-SPECIES : Chionaspis nyssae Comstock, 1881, by subsequent designation of Cooley, 1903: 38.

The authors established this genus as a segregate from Chionaspis Signoret in the Diaspidini. Lindinger, 1933a: 160, made the name a synonym of Trichomytilus Leonardi, later shifting the included species to Polyaspis Maskell [emended]. Takahashi, 1953: 48, after a study of the dimorphism oceurring in many of the species, rejected the validity of the genus and considered the name a synonym of Chionaspis. Recent coccid workers have accepted the genus as valid.

Phenacobryum Cockerell, 1902, Entomologist 35: 114.

TYPE-SPECIES : Planchonia bryoides Maskell, 1894, by subsequent designation of Borchsenius, 1960d: 110.

The author established this as a new section of Asterolecanium TargioniTozzetti. The name was immediately considered to be a synonym of Antecerococcus Green, 1901: 560, which Green, 1908: 41, decided was identical with Cerococcus Comstock, 1882. Borchsenius, 1960d: 104, 110, restored Phenacobryum to valid generic status, distinct from Antecerococcus and Cerococcus, both, in his opinion, also valid genera, and placed it in the Cerococcini, Cerococcinae, Asterolecaniidae.

Phenacoccopsis Borchsenius, 1948, Akad. Nauk SSSR Dok. (n. s.) 61: 954 .

TYPE-SPECIES: Phenacoccus agropyri Borchsenius, 1939, by original designation and monotypy.

The author placed this genus in the Pseudococcidae close to Phenacoccus Cockerell.

Phenacoccus Cockerell, 1893, Ent. News 4 : 318.

TYPE-SPECIES : Pseudococcus aceris Signoret, 1875, by subsequent designation by Fernald, 1903b: 89.

The author's proposal of this name to replace Pseudococcus of Signoret, 1875, met with acceptance by coccid workers. The type-species has been cited as identical with Chermes aceris Geoffroy, 1762, but the Geoffroy insect is now considered to be an aleyrodid.

Phenacoleachia Cockerell, 1899, Canad. Ent. $31: 274$.

TYPE-SPECIES : Leachia zealandica Maskell, 1891, by original designation and monotypy.

The author presented this genus in his Ortheziinae with the comment that it also had certain dactylopine features. Ferris, 1921b: 60, on the basis of study of the male, considered it a pseudococcine form of the general type of Puto 
Signoret. Morrison and Morrison, 1922: 14, redescribed the type-species and discussed the relationships of the genus, assigning it to a specially created subfamily, the Phenacoleachinae. Borchsenius, 1958b: $767-768$, placed it in the Phenacoleachiidae which he associated with the Ortheziidae and Margarodidae as the three most primitive groups of coccids.

Phenococcus Schmutterer, 1952, Ztschr. f. Angew. Ent. 33 : 396.

A lapsus for Phaenococcus Lindinger.

Philephedra Cockerell, 1898, Ann. and Mag. Nat. Hist. (ser. 7) 2: 24; 1899, Canad. Ent. 31 : 331.

TYPE-SPECIES: Pulvinaria ephedrae Cockerell, 1898, by original designation and monotypy.

The author presented this as a subgenus of Pulvinaria Targioni-Tozzetti. Steinweden, 1929: 222, placed it in the Exaeretopus Newstead group of the family Coccidae (str.) associated with Parafairmairia Cockerell and Luzulaspis Cockerell.

Philippia Targioni-Tozzetti, 1867, Soc. Ital. di Sci. Nat. Mem. 3 (3) : 13.

TYPE-SPECIES : Philippia follicularis Targioni-Tozzetti, 1867, by monotypy.

The author, 1868:33, substituted Fitippia for this generic name. See Filippia for details.

Philyrocecis Amyot, 1847, Soc. Ent. de France Ann. (ser. 2) 5: 502.

A uninomial designation to replace a generic and specific name for the insect ([Lecanium] tiliae $\mathrm{L} .=$ coryli L.) involved. It is without generic validity.

Phloeococcus Hoy, 1962, New Zeal. Dept. Sci. and Indus. Res. Bul. $146: 167$.

TYPE-SPECIES : Phloeococcus loriceus Hoy, 1962, by original designation.

The author placed this genus in the Eriococcidae, closely related to Notcococcus Hoy.

Phoenicoccus Ferris, 1957, Microentomology 22 : 65.

A lapsus for Phoenicococcus Cockerell.

Phoenicococcus Cockerell, 1899, Acad. Nat. Sci. Phila. Proc. 1899 : 262.

TYPE-SPECiEs : Phoenicococcus marlatti Cockerell, 1899, by original designation and monotypy.

The author associated this genus with pseudococcid genera. Sticknes, 1934:2. erected the I'hoenicococcinae, Phoenicococcini for it and a group of other unusual genera and placed them in the Diaspididae. Ferris, 1942: SIV-146 (66), and Balachowsky, 1948b : 260, agreed with this placement. See Stickney, 1934, for a detailed account of the anatomy and relationships of the type-species and genus.

Phoenococcus Fairchild, 1930, Exploring for Plants, pp. 198, 221.

A lapsus for Pseudococcus comstocki (Kuwana). 
Phylippia Leonardi, 1920, Monografia delle Coccinglie Italiane. P'ortici, p. 340.

A lapsus for Philippia Targioni-Tozzetti.

Phyllipia Kiritchenko, 1928, Zakhist Roslin No. 3-4 (1927-1928): 114.

A lapsus for Philippia Targioni-Tozzetti.

Phyllococcus Ehrhorn, 1916, Hawaii. Ent. Soc. Proc. 3: 234, 236.

TYPE-SPECIES : Cissococcus ? oahuensis Ehrhorn, 1912, by monotypy.

The author placed this gall-making genus in his Dactylopiinae [present Pseudococcidae]. Ferris, in Zimmerman, 1948:159, presented a recharacterization of the genus and type-species.

Phyllostroma Sulc, 1942, Ent. Listy [Brno] 5: 5-8.

TYPE-SPECIES : (Pulvinaria ericae Löw, 1883)=Lecanium myrilili Kaltenbach, 1874, by original designation and monotypy.

The author placed this genus in the Coccidae (str.) near Putvinaria TargioniTozzetti. Borchsenius, 1957 : 280, considered it close to Rhizopulvinaria Borchsenius. Schmutterer, 1952a: 554, placed the type-species in synonymy with myrtilli Kaltenbach, 1874, an action accepted by subsequent workers.

Physeriococcus Borchsenius, 1959, Ent. Obozr. 38:164.

TYPE-SPECIES : Physeriococcus cellulosus Borchsenius, 1959, by original designation and monotypy.

The author placed this genus close to Nidularia Targioni-Tozzetti in the Eriococcidae. Hoy, 1963, New Zeal. Dept. Sci. and Indus. Res. Bul. 150 : 12, confirmed its placement in this family.

Physochermes Targioni-Tozzetti, 1869, Soc. Ent. Ital. Bul. 1: 259.

A lapsus for Physokermes Targioni-Tozzetti. This spelling was also used by Bedwell, 1939, Suffolk Nat. Soc. Trans. 4:120, in combination with abietis Geoffroy.

Physococcus Hadzibejli, 1958, Ent. Obozr. 37 : 903.

TYPE-SPECIEs : Physococcus nanus Hadzibejli, 1958, by original designation and monotypy.

The author placed this genus in the Pseudococcidae close to Rhodania Goux. We believe that this name is a synonym of Ritsemia Lichtenstein, 1879a : 455-457. At hand are three mica preparations sent by Lichtenstein to Professor Comstock with the note: "Ritsemia pupifera male and female, very curious little animals on elm. I send ô 9-jointed ant, $q$ 8-jointed, and larva 6-jointed." The characters that are observable agree very well with the generic characterization presented for Physococcus. It is evident that two species were confused in Lichtenstein's published description. 
Physokermes Targioni-Tozzetti, 1868, (separate) Soc. Ital. di Sci. Nat. Atti 11: 41; 1869, 11: 734; Signoret, 1874, Soc. Ent. de France Ann. (ser. 5) 4:87.

TYPE-SPECIES : Coccus hemicryphus Dalman, 1825, by subsequent restriction of the genus to this single species by Signoret, 1874: 87 .

The author presented this genus without descriptive notes but with four associated species in the Lecanites. Signoret, 1874: 87, restricted the genus to hemicryphus Dalman and described both genus and species. Lindinger, 1933a: 117, considering quercus Linnaeus the type-species because it was first-named, placed Physokermes in synonymy with Kermes [Talla Heyden of Lindinger] because of identity of type-species. This action has not been accepted by other workers. Schmutterer, 1956: 454, reviewed the situation and confirmed hemicryphus Dalman, long considered a synonym of piceae Schrank, 1801, as the type-species and as distinct from piceae. Borchsenius, 1957: 439, accepted Physoliermes as valid but cited piceae Schrank as type-species and placed hemicryphus Dalman as a synonym of it.

Piannaspis Dunham, 1954 [Bahia], Bol. Inst. Biol. 1: 72.

A lapsus for Pinnaspis Cockerell.

Pilococcus Takahashi, 1928, Formosa Nat. Hist. Soc. Trans. 18 (97) : 257.

TYPE-SPECIES: Pilococcus miscanthi Takahashi, 1928, by original designation and monotypy.

The author placed this genus close to Ripersia Signoret in the Pseudococcidae.

Pinnapsis Lindinger, 1954, Beitr. z. Ent. 4:620.

A lapsus for Pinnaspis Cockerell.

Pinnaspis Cockerell, 1892, Inst. Jamaica Jour. 1:136.

TYPE-SPECIES: (Mytilaspis pandani Comstock, 1881)=Aspidiotus buxi Bouché, 1851, by subsequent designation of Fernald, 1903b : 242.

The author proposed this as a subgenus of Ifytilaspis Targioni-Tozzetti with two definitely included species, pandani Comstock and buxi Signoret. Its validity has never been challenged but there has been some uncertainty as to the relation of certain genera to it. Lindinger, $1912 \mathrm{~b}: 58$, 79. first indicated the synonymy of Hemichionaspis Cockerell with Pinnaspis. Jaapia Lindinger and Lepidaspidis MacGillivray are also considered to be synonyms. See Ferris and Rao, 1947 , for details.

Pityococcus McKenzie, 1942, Microentomology 7: 3-4.

TYPE-SPECIES: Pityococcus ferrisi McKenzie, 1942, by original designation.

The author established the Pityococcini in the Coelostomidiinae for this margarodid genus.

Planchonia Signoret, 1870, Soc. Ent. de France Ann. (ser. 4) 10: 282.

TYPE-SPECIES : Coccus fimbriatus Fonscolombe, 1834, by monotypy.

Signoret established this genus because he considered that fimbriatus Fonscolombe should be removed from Eriococcus, in which Targioni-Tozzetti had 
included it. Cockerell, 1893, Inst. Jamaica Jour. 1: 373, stated that Planchonia was a synonym of Asterolecanium Targioni-Tozzetti and this was accepted by his contemporary workers with the exception of Maskell, 1894: 94-95, and 1895a: 61, who insisted on the use of Planchonia because of his conviction that the name Asterolecanium was inaptly descriptive of the genus. Russell, 1941, accepted the synonymy of Planchonia with Asterolecanium. Bodenheimer, 1951: 328, recognized the genus as valid and included in it the seven "Group IV" species of the Russell monograph. Borchsenius, 1960d: 144, in his revision of the Asterolecaniidae, accepted the validity of Planchonia with the same seven included species.

Planococcoides Ezzat and McConnell, 1956, Md. Agr. Expt. Sta. Bul. A-84: 13, 53.

TYPE-SPECIES: Pseudococcus njalensis Laing, 1956, by original designation.

The authors placed this genus in the Pseudococcidae, Planococcini.

Planococcus Ferris, 1950, Atlas of the Scale Insects of North America (ser. 5) [v. 5]:22, 164 .

TYPE-SPECIES: Pseudococcus citri (Risso) of Ferris, 1950, by original designation.

Ezzat and McConnell, 1956: 3, erected the Planococcini to contain this and several related genera of the Pseudococcidae.

Plannococcus Entwhistle, 1958, Ghana Farmer 2:64.

A lapsus for Planococcus Ferris.

Platinglisia Cockerell, 1899, Entomologist $32: 12$.

TYPE-SPECIES : Platinglisia noacki Cockerell, 1899, by original designation and monotypy.

The author noted this genus as being closely allied to Inglisia Maskell in the Lecaniinae.

Platycoccus Stickney, 1934, U.S. Dept. Agr. Tech. Bul. 404: 107-108.

TYPE-SPECIES : Platycoccus tylocephalus Stickney, 1934, by original designation and monotypy.

The author placed this genus in his Phoenicococcinae, Phoenicococcini. Beardsley, 1963, Pacific Insects 5: 63-64, described the genus as an endemic [Hawaiian] offshoot of Colobopyga Bréthes.

Platycoccus Takahashi, 1959, Kontyu $27: 76$.

TYPE-SPECIES : Lecanium acuminatum Signoret, 1873, by original designation and monotypy.

The author placed this genus in the Coccidae (str.) related to Coccus Linnaeus and Protopulvinaria Cockerell. It is preoccupied by Platycoccus Stickney 1934, in the Phoenicococcinae. 
Platycoelostoma Morrison, 1923, in Morrison and Morrison, U.S. Natl. Mus. Proc. 62, Art. 17 (No. 2463) : 34.

TYPE-SPECIES : Coelostoma compressum Maskell, 1892, by original designation and monotypy.

The author placed this genus in the group of Margarodinae including Stcingelia Nassanov, Matsucoccus Cockerell, Stomacoccus Ferris, and Kuvania Cockerell, Morrison, 1927: 103, erected a new tribe for it, Platycoelostomini, in the Coelostomidiinae.

Platylecanium Cockerell and Robinson, 1915, Amer. Mus. Nat. Hist. Bul. 34: 427.

TYPE-SPECIES: Neolecanium cribrigerum Cockerell and Robinson, 1915, by original designation.

The authors presented this genus in the Lecaniinae.

Platypyga Green, 1918, Ann. Appl. Biol. 4:232, nomen nudum.

TYPE-SPECIES : Platypyga fagi [Green?], 1918, by monotypy, nomen nudum.

The name "Platypyga fagi" was presented in a list of coccid species affecting Fagus (Corylaceae) without other information. Hence it is a nomen nudum. Vayssière, 1926: [351], also presented the name in a host plant list. According to Neave, 1940, Nomen. Zool. III : 800 , the name was preoccupied by Illiger's use in the Mammalia in 1811.

Platysaissetia Cockerell, 1901, Ent. Student $2: 32$.

TYPE-SPECIES: Lecanium (Saissetia) castilloae Cockerell, 1898, by original designation and monotypy.

The author presented this as a subgenus of Saissetia Déplanche.

Pluvinaria Shinji, 1935, Zool. Soc. Japan, Tokyo, Dobutsugaku Zasshi 47 (566) : 771, 775.

A lapsus for Pulvinaria Targioni-Tozzetti.

Polea Green, 1922, The Coccidae of Ceylon. Part T, p. 162.

TYPE-SPECIES: Pollinia ceylonica Green, 1909, by original designation and monotypy.

The author placed this genus in the Asterolecaniinae with characters resembling Asterolecanium Targioni-Tozzetti.

Poliaspidoides Goux, 1937, Soc. Ent. de France Bul. 42 : 35.

A lapsus for Poliaspoides MacGillivray.

Poliaspis Maskell, 1880, New Zeal. Inst. Trans. and Proc. (1879) 12: 293.

TYPE-SPECIES : Poliaspis media Maskell, 1880, by monotypy.

The author described this diaspidine genus as very similar to Leucaspis Targioni-Tozzetti. It is accented by coccid workers as a valid genus. Balachowsky, 1954e: 171, 427, placed it in his Diaspidina, group II, chionaspiform. 
Poliaspoides MacGillivray, 1921, The Coccidae, p. 309.

TYPE-SPECIES: Chionaspis simplex Green, 1899, by original designation and monotypy.

The author placed this genus in the Diaspidini. Lindinger, 1937: 193, said "=Dycryptaspis Ckll." [Odonaspis]. Ferris, 1937a: 6, 33, considered the genus valid but transferred it to the Odonaspidini. Balachowsky, 1953g: 750, 760 , placed the name as a synonym of Rugaspidiotus MacGillivray.

Pollinia Targioni-Tozzetti, 1868, (separate) Soc. Ital. di Sci. Nat. Atti 11:41; 1869, 11:734; 1869, Soc. Ent. Ital. Bul.1:263.

TYPE-SPECiEs: (Pollinia costae Targioni-Tozzetti, 1868)=Coccus pollini A. Costa, 1857 , by monotypy.

Targioni-Tozzetti proposed this genus for the A. Costa species but with change of the specific name from pollini to costae. Since Rules do not permit such a change, the type must stand as cited above. A. Costa, 1877, noted the establishment of the new genus for his Coccus pollini and accepted the need for it, but rejected both the generic and specific names proposed. He substituted Cisticoocus, presenting the combination as Cisticoccus pollini, thus making his generic name an isogenotypic synonym of Pollinia Targioni-Tozzetti. Pollinia TargioniTozzetti has been accepted as a valid genus in the Asterolecaniidae. Borchsenius, 1960d : 128, placed it in the Cerococcinae, Polliniini.

Pollyocellaria Imhof, 1900, Biol. Centbl. 20 : 527, nomen nudum.

The author based this genus on the adult male of two coccids without mention of a species name. He suggested a possible relation to "Orther[z]ia cataphracta Sh[a]w."

Polyaspis Leonardi, 1898, in Berlese and Leonardi, Ann. di Agr. Rome (ser. 2) : 12 .

Leonardi presented this apparent misspelling of Poliaspis as; "Maskeliella Leon. (Polyaspis Maskl.)" Lindinger, 1935: 131, and 1937: 193, took this up as the proper spelling but later, 1943b: 224, accepted Poliaspis as correct. Other workers have not accepted Polyaspis.

Polyocellaria Sharp, 1901, Zool. Rec. (1900) 37:40, 332.

A lapsus for Pollyocellaria Imhof. The name was placed under Aphididae by Sharp. Kirkaldy, 1906, Canad. Ent. 38: 10, repeated this, but indicated that the placement was doubtful. Sanders, 1906: 2, used this spelling but placed the name in the Ortheziinae. Kiritchenko, 1940: 120, listed the name erroneously in combination with radicumgraminis as a synonym of Lecanopsis TargioniTozzetti.

Polystomophora Borchsenius, 1948, Akad. Nauk SSSR Dok. (n. s.) 61:955.

TYPE-SPECIES : Phenacoccus ostiapturimus Kiritchenko, 1940, by original designation and monotypy.

The author placed this genus in the Pseudococcinae close to Mirococcus Borchsenius. 
Porceraspis Ferris, 1938, Microentomology $3: 75$.

A lapsus for Proceraspis MacGillivray.

Porococcus Cockerell, 1898, Ann. and Mag. Nat. Hist. (ser. 7) 1:426. TYPE-SPECIES : Porococcus tinctorius Cockerell, 1898, by original designation.

The author suggested a relationship with Solenophora Maskell. Ferris, 1920a: 61, considered this a pseudococcine form in the group associated with Pseudococcus Westwood and structurally similar to Erioides Green.

Porogymnaspis Green, 1916, Bul. Ent. Res. $7: 55$.

TYPE-SPECIES: Porogymnaspis rufa Green, 1916, by subsequent designation by Ferris, 1936a : 23.

The author associated this genus with Gymnaspis Newstead, Parlatoria Targioni-Tozzetti, and Leucaspis Targioni-Tozzetti, most nearly related to Leucaspis. Lindinger, 1934: 26, placed the name as a synonvm of Apteronidia Berlese. Ferris, 1936a: 23, accepted the genus as valid, and Balachowsky, 1958b: 342, placed it in his Gymnaspidina, grouping with Gymnaspis Newstead, Decoraspis Ferris, Bigymnaspis Balachowsky and Sakaramyaspis Mamet.

Porphirophora Targioni-Tozzetti, 1867, Soc. Ital. di Sci. Nat. Mem. $3(3): 18$.

A lapsus for Porphyrophora Brandt.

Porphyrophora Brandt, 1833, in Brandt and Ratzeburg, Medizinische Zoologie oder getreue Darstellung und Beschreibung der Thiere, die in der Arzeneimittellehre in Betracht kommen, in systematischer Folge $2: 355$.

TYPE-SPECIES: (Porphyrophora frischii Brandt, 1883)=Coccus polonicus Linnaeus, 1758, apparently by subsequent designation of Kirkaldy, 1906a: 254 (the first we have found).

This genus was established after Margarodes Guilding, 1829, and was used for many years for the reception of the European species of that genus. Later, the name was considered a synonym of Margarodes by Lindinger, 1912b: 307 ; 1937: 193, and Morrison, 1928: 220. Silvestri, 1938: 35, on the basis of examination of rarious species, decided that Porphyrophora should be restored to valid status. Hall, 1940: 494; Borchsenius, 1949: 336 ; Jakubski, 1950: 398; Dzhafarov, 1956, Akad. Nauk Azerbaid. SSR Izv. 11: 88; Hadzibejli, 1957: 211, have accepted this view.

Powellia Maskell, 1879, New Zeal. Inst. Trans. and Proc. (1878) 11: 223.

TYPE-SPECIES: Powellia vitreoradiata Maskell, 1879, by monotypy.

Originally described as a coccid, it is now placed as a psyllid. 
Praecocaspis Ferris, 1942, Atlas of the Scale Insects of North America (ser. 4) [v. 4]: SIV-410.

TYPE-SPECIES : Praecocaspis diversa Ferris, 1942, by original designation and monotypy.

The author placed this genus in the Diaspidinae, Diaspidini. No subsequent mention of the type-species has been found.

Priococcus Fulmek, 1943, Ent. Beihefte aus Berlin-Dahlem 10 : 32, 60.

A lapsus for Eriococcus Targioni-Tozzetti.

Proceraspis MacGillivray, 1921, The Coccidae, p. 312.

TYPE-SPECIES: Chionaspis cinnamomi Green, 1905, by original designation and monotypy.

The author placed this genus in the Diaspidini. Lindinger, 1937: 193, accepted it as valid. Ferris, 1937a: 6, considered it valid as separated from Chionaspis Signoret. Balachowsky, 1954e: 172, assigned it to his Diaspidina, group II, chionaspiform.

Prodigiaspis Ferris, 1941, Atlas of the Scale Insects of North America (ser. 3) [v.3]: SIII-312.

TYPE-SPECIES : Prodigiaspis septunx Ferris, 1941, by original designation and monotypy.

The author placed this genus in the Diaspidini but noted resemblances to Poliaspoides MacGillivray. Balachowsky, 1954e: 23, assigned it to the Lepidosaphedina.

Promargarodes Silvestri, 1938, Notes d'Ent. Chionoise 5: 21.

TYPE-SPECIES: Promargarodes sinensis Silvestri, 1938, by original designation and monotypy.

The author placed this genus in the Margarodinae, closest to Neomargarodes Green.

Prontaspis MacGillivray, 1921, The Coccidae, p. 311.

TYPE-SPECIES : Chionaspis citri Comstock, 1883, by original designation.

This name is currently placed as a synonym of Unaspis MacGillivray.

Prosopophora Douglas, 1892, Ent. Monthly Mag. 28:207.

TYPE-SPECIES : Prosopophora dendrobii Douglas, 1892, by monotypy.

The author noted an inability to assign this genus to relationship or position in any group of the Coccidae (str.). Cockerell, 1896i: 50, considered it not separable from Lecaniodiaspis Targioni-Tozzetti. Green, 1901i: 293, accepted this synonymy and subsequent workers have concurred until Borchsenius, 1960d: 223, restored the genus to valid status. He described five new species, and suggested transfer of four previously described species to it. 
Protancepaspis Borchsenius and Bustshik, 1959, Ent. Obozr. 38: 160.

TYPE-SPECIES : Protancepaspis bidentata Borchsenius and Bustshik, 1959, by original designation and monotypy.

The authors placed this genus in the Phoenicococcidae, close to Ancepaspis Ferris.

Protargionia Leonardi, 1911, Portici R. Scuola Super. di Agr., Lab. Zool. Gen. e Agr. Bol. 5 : 280.

TYPE-SPECIES: Protargionia larreae Leonardi, 1911, by monotypy.

The author suggested that this genus agreed in general characters with Targionia Signoret, but subsequent workers placed it in the Diaspidini. Lindinger, 1932f: 204, and 1937: 193, assigned it to synonsmy with Pseudoparlatoria Cockerell. Borchsenius and Williams, 1963, Brit. Mus. (Nat. Hist.) Ent. Bul. 13: 366, regarded the genus as distinct but with striking similarity to Diaspis Costa and plainly a member of the Diaspidini.

Protartonia Weber, 1935, Biol. der Tiere Deut. 38 (31) : 328.

A lapsus for Protortonia Townsend.

Proteriococcus Borchsenius, 1960, Ent. Obozr. 39 : 916.

TYPE-SPECIES: Proteriococcus acutispinus Borchsenius, 1960, by original designation.

The author assigned this genus to the Eriococcidae, close to Acanthococcus Signoret. Hoy, 1963, New Zeal. Dept. Sci. and Indus. Res. Bul. 150:12, accepted it in the Eriococcidae.

Proticerya Cockerell, 1895, Psyche (sup.) $7: 15$.

TYPE-SPECIES: Icerya rilcyi Cockerell, 1895, by original designation and monotypy.

The author presented this as a subgenus of Iccrya Signoret. Morrison, 1928: 220 , placed it in synonymy with Icerya Signoret.

Protodiaspis Cockerell, 1898, Ann. and Mag. Nat. Hist. (ser. 7) 1: 428.

TYPE-SPECIEs : Protodiaspis parvulus Cockerell, 1898, by original designation and monotypy.

The author placed this genus in the Diaspinae and suggested that it connected the Diaspinae with the Coccinae (str.). Ferris, 1919a: 46, accepted the genus as ralid in the Diaspidini. Balachowsky, 1953g: \$42, considered that its affinities with the Lencaspidina were indisputable. Sce Brown and McKenzie, 1962, for discussion of the morphological diversity of the genus and its interpretation.

Protopulvinaria Cockerell, 189t, Trinidad Field Nat. Club Jour. 1: 309-310.

TYPE-SPECIES: Pulvinaria (Protopulvinaria) pyriformis Cockerell, 1894, by original designation and monotypy.

The anthor presented this as a subgenus of Pulvinaria Targioni-Tozzetti, noting also its closeness to Lecanium mangiferae and allies. The Fermald, 1903b:128, 
assignment of Pulvinaria convexa Hempel as trpe-species, which was repeated by Gómez-Menor, 1958b : 73, and Borchsenius, 1957: 289, is incorrect. The Lindinger, $1937: 193$, emendation of the spelling of the name of the type-species to piriformis has not been accepted.

Protortonia Townsend, 1898, in Townsend and Cockerell, N.Y. Ent. Soc. Jour. $6: 169$.

TYPE-SPECIES : Ortonia primitiva Townsend, 1898, by original designation.

This was established as a subgenus of Ortonia Signoret, raised to generic rank by Cockerell, 1899a : 390, and then suppressed by Fernald, 1903b : 16, as congeneric with Llaveia Signoret, which had supplanted Ortonia. Morrison, 1928:189, on the basis of a study of the type-species, restored Protortonia to valid generic status in the Llaveiini. Hughes-Schrader, 1940:331, on a cytological basis, placed it as the most highly specialized of the three genera of this tribe.

Pseudalichtensia Hempel, 1928, Inst. Biol. [Sao Paulo] Arch. 1:237.

TYPE-SPECIES: Pseudalichtensia brasiliae Hempel, 1928, by original designation and monotypy.

The author placed this genus in the Lecaniinae and noted superficial similarities, but structural differences, with Platinglisia Cockerell.

Pseudantonina Green, 1922, The Coccidae of Ceylon. Part V, p. 363.

TYPE-SPECIES : Pseudantonina bambusae Green, 1922, by original designation and monotypy.

The author placed this genus in his Dactylopiinae [current Pseudococcidae] intermediate between Antonina Signoret and Ripersia Signoret. See Borchsenius, $1960 \mathrm{e}: 923$, for revision of the genus with new diagnosis.

Pseudaonidia Cockerell, 1897, U.S. Dept. Agr., Div. Ent., Tech. Ser. $6: 14$.

TYPE-SPECIES : Aspidiotus duplex Cockerell, 1896, by original designation.

The author established this as a subgenus of Aspidiotus Bouché, raising it to full generic status, $19011: 226$. Lindinger, $1910: 156$, placed it in the Parlatoreae group with Furcaspis Lindinger. Ferris, $1937 \mathrm{c}: 52$, 55 , considered it valid in the Aspidiotini. Balachowsky, 1948b : 269, assigned it to the Pseudoaonidina.

Pseudaonidiella MacGillirray, 1921, The Coccidae, p. 394.

TYPE-SPECIES: Aspidiotus duplex Cockerell var. paeoniae Cockerell, 1899. bJ original designation and monotypy.

Lindinger, $1937:$ 194, and Ferris, 1937c: 52 , 5̃, placed this name in synonymy with Pseudaonidia Cockerell. Other workers share this viem.

Pseudaspidoproctus Morrison, 1927, Biol. Soc. Wash. Proc. 40: 104.

TYPE-SPECIES : Aspidoproctus hypheniacus Hall, 1925, by original designation and monotypy.

The author placed this genus, established for sereral African species, in his group 1 of the Monophlebini. 
Pseudaulacaspis MacGillivray, 1921, The Coccidae, p. 305.

TYPE-SPECIES: Aulacaspis pentagona Targioni-Tozzetti, 1886, by original designation.

The genus has been generally accepted as valid in the Diaspidini. Ghauri, 1962: 213, placed it in the Chionaspidina on characters of the adult male.

Pseudinglisia Newstead, 1893, Ent. Monthly Mag. 29 :153.

TYPE-SPECIES : Pseudinglisia rodrigueziae Newstead, 1893, by monotypy.

The author expressed doubt as to the position this genus should occupy, in the Lecaniinae or the Coccinae (str.). Cockerell, 1896b:323, placed the name in synonymy with Conchaspis Cockerell. Mamet, 1954b : 208, confirmed this synonymy and accepted the type-species as identical with Conchaspis angraeci Cockerell.

Pseudischnaspis Hempel, 1900, Rev. Mus. Paulista [São Paulo] 4: 506.

TYPE-SPECIES : (Pseudischnaspis linearis Hempel, 1900)=Aspidiotus bowreyi Cockerell, 1893, by original designation and monotypy.

The author noted a superficial resemblance to Ischnaspis Douglas and a similarity to Chrysomphalus Ashmead in pygidial structure. The genus has been accepted as valid in the Aspidiotini.

Pseudoaunidia Minamikawa, 1959, Okitsu. Natl. Tokai-Kinki Agr. Expt. Sta., Tea Div., Study of Tea No. $20: 41$.

A lapsus for Pseudaonidia Cockerell.

Pseudocapulinia Hempel, 1932, Rev. de Ent. [São Paulo] 2: 319.

TYPE-SPECIES : Pseudocapulinia lanosa Hempel, 1932, by original designation and monotypy.

The describer placed this genus in the Cylindrococcinae, close to Capulinia Signoret.

Pseudochermes Nitsche, 1895, in Judeich und Nitsche-Lehrbuch der mitteleuropäischen Forstinsektenkunde II : 1249.

TYPE-SPECIES: Chermes? fraxini Kaltenbach, 1860, by original designation and monotypy.

Lindinger, $1937: 179,185$, 194, considered this genus valid and placed Apterococcus Newstead, 1898, and Fonscolombia Cockerell, 1899j : 264 (non Fonscolombia Lichtenstein, 1877), in synonymy. Borchsenius, 1949: 365, followed this interpretation in his redescription of the genus. Hoy, 1963, New Zeal. Dept. Sci. and Indus. Res. Bul. 150:13, accepted Pseudochermes in the Eriococcidae. We cannot accept Schmutterer's action, 1952: 418, in placing Pseudochermes Nitsche, 1895, with fraxini Kaltenbach cited as type-species, in synonymy with Fonscolombia Lichtenstein, 1877. See under Fonscolombia.

Pseudoccus Westwood, 1840, An Introduction to the Modern Classification of Insects $2: 445$.

A lapsus for Pseudococcus Westwood. 
Pseudococes Takahashi, 1958, Univ. Osaka (Prefecture) Bul. (ser. B) $(1957) 7: 3$.

A lapsus for Pseudococcus Westwood.

Pseudo-Coccus Westwood, 1840, An Introduction to the Modern Classification of Insects $2: 448$.

This spelling also appeared in Westwood, 1845, Arcana Entomologica 1: 21, as Pseudo-coccus.

Pseudococcus Westwood, 1840, An Introduction to the Modern Classification of Insects $2: 448$, appendix 118.

TYPE-SPECIES: Coccus adonidum Linnaeus, 1767 (longispinus TargioniTozzetti, 1868), by subsequent designation of Fernald, 1903b: 96.

The position of Pseudococcus as a valid generic name in the Coccoidea is exceedingly insecure. Westwood (p. 448) definitely associated "the cochineal insect of Mexico, Coccus cacti Linn.," with his generic name "Pseudo-Coccus," mentioning no other species, but in the generic synopsis in the appendix (p. 118), listed "Pseudococcus Westw. (C. adonidum, Cacti, etc.)." Since Dactylopius had been used in 1835 by Costa for the cochineal insect, Pseudococcus was a synonym of that name. In 1875 Signoret published an entirely different concept of Pseudococcus, using it for mealybug species which Cockerell, 1893ee: 317, placed in Phenacoccus, and assigning to Dactylopius, not the cochineal insect, but a group of mealybugs of the type of adonidum Linnaeus. This practice was followed in coccid literature for 25 years. The Fernald Catalogue, 1903b: 96, changed the picture by presenting Pseudococcus Westwood, with type-species longispinus Targioni-Tozzetti (adoniäum Linnaeus) for the mealybug species that Signoret had placed in Dactylopius, and Phenacoccus Cockerell for the species Signoret had placed in Pseudococcus. Kirkaldy, 1904a: 227, 258, pointed out that Pseudococcus, as a synonym of Dactylopius and referring to only the cochineal insect of Mexico, should be replaced by Trechocorys Curtis, 1843. However, coccid workers have ignored Kirkaldy's decision, and have followed the usage of the Fernald Catalogue. Laing, 1944: 93, and Ferris, 1950b : 170-171, while recognizing and discussing this anomalous situation, continued to use the name Pseudococcus. Strict adherence to the rules of nomenclature would require its rejection, but the fact that Pseudococcus, with adonidum as typespecies, has been used for 45 years for a group of mealybugs, with a large amount of literature built up around it, suggests the desirability of an arbitrary decision to make its continued use valid.

Pseudococus Dunham, 1954 [Bahia] Bol. Inst. Biol. 1: 68, 72.

A lapsus for Pseudococcus Westwood. This spelling also appeared in Juscafresa 1961, El Cultivador Moderno 44 : 96.

Pseudodaulacaspis Laffoon, 1961, Ent. Soc. America Bul. 6: 191.

A lapsus for Pseudaulacaspis MacGillivray. Corrected in 1.c. $7: 93$. 
Pseudodiaspis Cockerell, 1897, U.S. Dept. Agr., Div. Ent., Tech. Ser. $6: 21$.

TYPE-SPECIES: Aspidiotus (Pseudodiaspis) larreae Cockerell, 1897, by monotypy.

The author presented this as a subgenus of Aspidiotus Bouché. Ferris, 1919a : 52 , accepted it as a ralid genus but suggested assignment to the diaspine series rather than to the aspidiotine. Balachowsky, 1954e: 167, placed it in the Diaspidina, group I, diaspiform.

Pseudodiospis Lindinger, 1957, Beitr. z. Ent. $7: 547$.

A lapsus for Pseudodiaspis Cockerell.

Pseudodischnaspis Flachs, 1931, Krankheiten und Parasiten der Zierpflanzen, p. 298.

A lapsus for Pseudischnaspis Hempel. This spelling also appeared in Balachowsky, 1951 : 583 , and $1958 \mathrm{~b}: 202$.

Pseudodocus Dunham, 1954 [Bahia] Bol. Inst. Biol. 1: 67.

A lapsus for Pseudococcus Westwood.

Pseudokermes Cockerell, 1895, Canad. Ent. 27: 203.

TYPE-SPECIES : Lecanium (Pseudokermes) nitens Cockerell, 1895, by monotypy.

The author presented this as a subgenus of Lecanium Burmeister noting similarities to Physokermes Targioni-Tozzetti, Inglisia Maskell, and Fairmairia Signoret.

Pseudolacaspis Dunham, 1954 [Bahia] Bol. Inst. Biol. 1:67.

A lapsus for Pseudaulacaspis MacGillivray.

Pseudolecanium Cockerell, 1896, Psyche (sup.) $7: 19$.

TYPE-SPECIES: Sphaerococcus (Pseudolecanium) tokionis Cockerell, 1896, by monotypy.

This genus was established as a subgenus of sphaerococcus Maskell. Fernald Catalogue, 1903b: 210, listed the name as a synonym of Aclerda Signoret, and McCommell, 1954: 23, confirmed this placement.

Pseudoleucaspis Mamet, 1939, Roy. Ent. Soc., London, Trans. 89 : 586.

TYPE-SPECIES : Pscudoleucaspis monticola Mamet, 1939, by original designation and monotypy.

The author noted a relation to Leucaspis Targioni-Tozzetti by nature of the female puparium, and differences from members of the Diaspinae in the pygidium of the nymphal exuvium and that of the adult female.

Pseudomelanaspis Borchsenius, 1952, Ent. Obozr. 32 : 262.

TYPE-SPECIEs : Pseudomelanaspis minima Borchsenius, 1952, by original designation and monotypy.

The author placed this aspidiotine genus close to Melanaspis Cockerell. 
Pseudoparlatorea Lindinger, 1905, Insekten Börse 22 : 131.

An emendation of Pseudoparlatoria that has met with slight acceptance except by Lindinger himself.

Pseudoparlatoria Cockerell, 1892, Inst. Jamaica Jour. 1: 136.

TYPE-SPECIES : Pseudoparlatoria ostreata Cockerell, 1892, by subsequent designation of Fernald, 1903b : 300.

The author presented this as "n.g. or subg. of Aspidiotus." He later noted the resemblance of the female scales to those of Aspidiotus Bouché and of the male scales to female scales of Parlatoria Targioni-Tozzetti. Subsequent workers have accepted the genus as valid in the Diaspidini. Balachowsky, 1954e: 255, assigned it to the Diaspidina and noted a closeness to Malleolaspis Ferris.

Pseudophilippia Cockerell, 1897, Psyche 8: 89.

TYPE-SPECIES: Pseudophitippia quaintancii Cockerell, 1897, by monotypy.

The author placed this as a lecanine genus allied to Filippia Targioni-Tozzetti. We consider that the genus associates with Toumeyella Cockerell in a special group of the Coccidae (str.).

Pseudopsylla Froggatt, 1921, N. S. Wales Dept. Agr. Sci. Bul. 19: 6. TYPE-SPECIES : Pseudopsylla hirsuta Froggatt, 1921, by monotypy.

The only further mention of this genus of gall-making coccids that we have found is in the Lindinger, $1937: 194$, list of coccid genera.

Pseudopulvinaria Atkinson, 1889, Asiatic Soc. Bengal Jour. 58 (pt. 2, no. 1) : 4 .

TYPE-SPECIES : Pseudopulvinaria sikkimensis Atkinson, 1889, by monotypy.

The author placed this genus in Maskell's Hemicoccina, with some structural characters of the Coccina and some of the Lecanina. Ferris, 1957c: 88, considered that a case could be made for its assignment to the Eriococcidae and also to the Coccidae (str.). Hoy, 1963, New Zeal. Dept. Sci. and Indus. Res. Rul. $150: 13$, agreed.

Pseudorhizoecus Green, 1933, Stylops 2: 55.

TYPE-SPECIES : Pseudorhizoecus proximus Green, 1933, by original designation.

The author placed this genus of root coccids in the Pseudococeinae, noting that superficially it appeared similar to Rhizoecus Künckel d'Hereulais, but that the structural characters were very distinct.

Pseudorhodania Borchsenius, 1962, Akad. Nauk SSSR Zool. Inst. Trudy $30: 242-244$.

TYPE-SPECIES : Pseudorhodania marginata Borchsenius, 1962, by original designation and monotypy.

The author placed this genus in the Phenacoccini, Pseudococcidae, close to Rhodania Goux. 
Pseudoripersia Cockerell, 1899, Ill. Nat. Hist. Survey Bul. 5: 392.

TYPE-SPECIES : Eriococcus turgipes Maskell, 1893, by monotypy.

The author established this as a subgenus of Ripersia Signoret and subsequently raised it to generic rank. Morrison and Morrison, 1922: 51 , redefined the genus and redescribed the type-species. It is assigned to the Pseudococcidae.

Pseudorrhizoecus Lindinger, 1937, Ent. Jahrb. 46 : 194.

A lapsus for Pseudorhizoecus Green.

Pseudoselenaspidus J. P. da Fonseca, 1962, Inst. Biol. [Sao Paulo] Arch. 29:26.

TYPE-SPECIES : Pseudoselenaspidus inermis J. P. da Fonseca, 1962, by original designation and monotypy.

The author differentiated this aspidiotine genus from Selenaspidus Cockerell.

Pseudotargionia Lindinger, 1912, Die Schildläuse, pp. 14, 50, 386.

TYPE-SPECIES : Aonidia glandulosa Newstead, 1911, by monotypy.

The author established this aspidiotine genus without characterization, placing it in his Parlatoreae group of the Diaspinae and listing it with the valid species at the end of the book. He, 1932f: 199, called attention to its incorrect citation as a subgenus in Supplement 5 of the Fernald Catalogue. Ferris, 1937c: $\mathbf{2} 2,55$, regarded the genus as valid, an opinion confirmed by Balachowsky, 1948b : 269, who assigned it to the Pseudoaonidina and, 1951: 676, defined the genus and differentiated it from the closely allied Pseudaonidia Cockerell.

Pseudotectococcus Hempel, 1934, [Sao Paulo] Rev. de Ent. 4: 139.

TYPE-SPECIES : Pseudotectococcus annonae Hempel, 1934, by original designation and monotypy.

The author placed this genus in the Eriococcinae close to Tectococcus Hempel. Ferris, 1957c: 88, accepted it as definitely eriococcid and Hoy, 1963, New Zeal. Dept. Sci. and Indus. Res. Bul. 150: 13, agreed with its placement in the Eriococcidae.

Psilococcus Borchsenius, 1952, Akad. Nauk SSSR Zool. Inst. Trudy $12: 269$.

TYPE-SPECIES: Psilococcus ruber Borchsenius, 1952, by original designation and monotypy.

The author placed this genus in the Coccidae (str.) near Lecanopsis TargioniTozzetti.

Psoraleococcus Borchsenius, 1959, Ent. Obozr. 38 : 841.

TYPE-SPECIES: Psoraleococcus verrucosus Borchsenius, 1959, by original designation.

The author placed this genus in his Iecaniodiaspididae close to Anomalococcus Green. 
Pteleocecis Amyot, 1847, Soc. Ent. de France Ann. (ser. 2) 5: 502.

This is a uninomial designation intended to replace a generic and specific name for the species involved, Lecanium coryli (Linnaeus), as we interpret it. It has no validity as a generic name.

Pterolecanium Sulc, 1932, Acta Soc. Sci. Nat. Morav. 7(5) (Signatura F 57) : 48, 53 .

TYPE-SPECIES: Lecanium pulchrum [King MS] Reh, 1903, nomen nudum; Marchal, 1908, by monotypy.

The author presented this as a subgenus of Lecanium Burmeister but it was not accepted by other workers. Bodenheimer, 1929: 97, placed it in synonymy with Eulecanium Cockerell, and Borchsenius, 1957: 374, with Parthenolecanium Sulc. The name of the type-species is considered a synonym of rufulum Cockerell.

Pudaspis Hall, 1946, Roy. Ent. Soc., London, Trans. 97 : 530-531.

TYPE-SPECIES: Diaspis newsteadi Leonardi, 1914, by original designation.

The author referred this genus to the Diaspidini and noted its differentiation from Diaspis Costa. Balachowsky, 1954e: 167, placed it in the Diaspidina, group I, diaspiform.

Pulvinaria Targioni-Tozzetti, 1866, R. Accad. dei Georg. Atti (n.s.) $13: 146 ; 1867$, Soc. Ital di Sci. Nat. Mem. $3(3): 13$.

TYPE-SPECIES: Coccus vitis Linnaeus, 1758, by original designation and monotypy.

The author presented this genus with a brief comment on the floccose material produced by its type-species; again, 1867: 13, he eited the genus and its typespecies in a footnote; and in his catalog, 1868: $34,1869: 727$, associated it with his Nidularia in sect. B, Pulvinati, of his tribe "Lecanites." Throughout subsequent coccid literature, a large number of species have been referred to $P u l$ vinaria. Steinweden, 1929: 226, and 1946:3, accepted Coccus vitis Linnaeus as type-species and precisely redefined the genus. Borchsenius, 1952a : 296-297, and 1953: 287-288, separated 8 new genera from Pulvinaria and, 1957: 202-203, placed it in the Pulvinariini, Coccinae (str.).

Pulvinariella Borchsenius, 1953, Ent. Obozr. 33 : 287.

TYPE-SPECIES : Coccus mesembryanthemi Vallot, 1830, by original designation and monotypy.

The author placed this genus in the Coccidae (str.) close to Rhizopulvinaria Borchsenius.

Pulvinarisca Borchsenius, 1953, Ent. Obozr. 33 : 288.

TYPE-SPECIES : Pulvinaria serpentina Balachowsky, 1929, by original designation and monotypy.

The author placed this genus in the Coccidae (str.) near Phyllostroma Sulc. 
Pulvinatus Signoret, 1875, Soc. Ent. de France Ann. (ser. 5) 5: 16.

From the context in which this name occurs, we suppose that it is a lapsus for Nidularia Targioni-Tozzetti of authors. No species was associated with it so it has no standing.

Pulvinella Hempel, 1899, Canad. Ent. 31: 132.

TYPE-SPECIES : Pulvinaria pulchella Hempel, 1899, by original designation and monotypy.

The describer presented this as a subgenus of Putvinaria Targioni-Tozzetti allied to Pendularia da Fonseca, in the Lecaniinae.

Pusillaspis Lindinger, 1906, Jahrb. der Hamburg. Wiss. Anst. (190ð) 23 Beih. $3: 27$.

TYPE-SPECIES : Leucaspis pusilla Löw, 1883, by subsequent designation of MacGillivray, 1921 : 262.

This name was proposed for an uncharacterized subdivision of a "Sektion" of the genus Lencaspis Targioni-Tozzetti. It was established as a definite subgenus with pusilla Löw designated as type by MacGillivray. Ferris, 1936a: 23-24 and Balachowsky, 1953g: 860, considered the type-species to be a Leucaspis.

Puto Signoret, 1876, Soc. Ent. de France Ann. (1875) (ser. 5) $5: 394$. TYPE-SPECIES : Putonia antennata Signoret, 1875, by substitution of Puto for Putonia Signoret.

The author proposed this name as a replacement for his Putonia, 1875 .

Putonia Signoret, 1875, Soc. Ent. de France Ann. (ser. 5) 5:341. TYPE-SPECIES : Putonia antennata Signoret, 1875, by monotypy.

This name was preoccupied by Putonia Stål, 1872, in the Heteroptera, and was replaced by Puto Signoret, 1876.

Pygalataspis Ferris, 1921, Bul. Ent. Res. 12 : 218.

TYPE-SPECIES : Pygalataspis miscanthi Ferris, 1921, by original designation and monotypy.

The author placed this genus in the Diaspis O. G. Costa series of the Diaspididae, but noted certain characters that closely resembled characters of Odonaspis Leonardi.

Pygidiaspis MacGillivray, 1921, The Coccidae, p. 392.

TYPE-SPECIES : Aspidiotus (Targionia) cedri Green, 1915, by original designation and monotypy.

Lindinger, 1937 : 194, placed this name of an aspidiotine genus as a synonym of Targionia Signoret. Ferris, 1937e: 55, considered it a valid genus with some connection with Loranthaspis Cockerell and Bueker, and 1943a : \&5, stated that it was definitely not a Targionia. 
Pygmaeococcus McKenzie, 1960, Hilgardia 29 : 741.

TYPE-SPECIES : Pygmaeococcus morrisoni McKenzie, 1960, by original designation and monotypy.

The describer placed this genus in the Pseudococcidae, most closely related to Rhizoecus Künckel d'Herculais.

Pyrogymnaspis Ramakrishna Ayyar, 1919, Pusa Agr. Res. Inst. Bul. $89: 99$.

A lapsus for Porogymnaspis Green.

Pyrophora Lindinger, 1935, Ent. Jahrb. 44:141.

A lapsus for Porphyrophora Brandt.

Quadraspidiotus MacGillivray, 1921, The Coccidae, p. 388.

TYPE-SPECIES : Aspidiotus ostreaeformis Curtis, 1843, by original designation.

This genus has received general acceptance in the Aspidiotini. Ferris, 1938a : SII-255, and 1943a: 95, discussed and defined the genus. Balachowsky, 1950b: 397, placed it in the Aspidiotina. De Lotto, 1963, Ent. Soc. South. Africa Jour. 26: 144-145, also discussed this genus and Diaspidiotus Berlese and Leonardi. See discussion under Diaspidiotus.

Querceticoccus Lindinger, 1933, Ent. Anz.13:117.

TYPE-SPECIES : Coccus pulvinatus Planchon, 1864, by original designation and monotypy.

The author proposed this generic name as a substitute for Nidularia of authors and current usage, after replacing Eriococcus Targioni-Tozzetti with Nidularia Targioni-Tozzetti on the basis of acceptance of first included species as typespecies of a genus. See under Nidularia.

Quercetococcus Lindinger, 1943, Ztschr. der Wien. Ent. Gesell. 28: 264.

An emendation of Querceticoccus Lindinger.

Querinococcus Carus, 1912, Bibliog. Zool. 22 : 88.

A lapsus for Guerinococcus Berlese.

Quernaspis Ferris, 1937, Atlas of the Scale Insects of North America (ser. 1) [v. 1] : SI-118.

TYPE-SPECIES: Chionaspis quercus Comstock, 1881, by original designation and monotypy.

The author placed this genus in the Diaspidini. Balachowsky, 1954e: 172, placed it in the Diaspidina, group II, chionaspiform.

$208-496-66-12$ 
Radiaspis Ferris, 1938, Atlas of the Scale Insects of North America (ser. 2) [v. 2] : SII-152.

TYPE-SPECIES : Leucaspis indica Marlatt, 1908, by original designation and monotypy.

The author referred this genus to the Diaspidini with doubt. Later, 1942: SIV-422, recognizing the prior use of the name by Richter, 1917, for a trilobite, he substituted the name Radionaspis.

Radicoccus Hambleton, 1946, Rev. de Ent. [Rio de Janeiro] 17: 47. TYPE-SPECIES: Rhizoecus globosus James, 1935, by original designation.

The author placed this genus near Ripersiella Tinsley, in the group of rootinfesting genera of the Pseudococcidae.

Radiococcus Hambleton, 1946, Rev. de Ent. [Rio de Janeiro] 17: 10.

A lapsus for Radicoccus Hambleton. Lindinger, 1957 : 551, accepted this spelling, but considered the name a synonym of Rhizoecus Künckel d'Herculais.

Radionaspis Ferris, 1942, Atlas of the Scale Insects of North America (ser.4) [v.4]:SIV-422.

TYPE-SPECIES : Leucaspis indica Marlatt, 1908, by substitution of Radionaspis for Radiaspis Ferris.

Balachowsky, 1953g: 842, assigned this genus to the Leucaspidina. Ferris, $1955 \mathrm{c}: 31$, noted the agreement, in great reduction of characters, of this genus with Anotaspis Ferris and Thysanaspis Ferris.

Ramachandraspis Rao, 1953, Roy. Ent. Soc., London, Proc. Ser. B: Taxonomy $22: 66$.

TYPE-SPECIES : Ramachandraspis fenestrata Rao, 1953, by original designation and monotypy.

The describer assigned this genus to the Diaspidini. Ramakrishna Ayyar, 1924, 1926, and 1930, presented the type-species in lists of Indian Coccidae as Fiorinia fenestrata Green (MS).

Rastrococcus Ferris, 1954, Microentomology $19: 55$.

TYPE-SPECIES : Phenacoccus iceryoides Green, 1908, by original designation.

The author established this genus in the Phenacoccus Cockerell series of the Pseudococcidae. Lindinger, 1958:372, placed the type-species as "Ceroputo iceryoides (Gr. 1908) comb. n.," but this action has not been accepted by other workers.

Remotaspidiotus MacGillivray, 1921, The Coccidae, p. 391.

TYPE-SPECIES : Aspidiotus (Targionia) chenopodii Marlatt, 1908, by original designation.

The author placed this genus in the Diaspidini. Lindinger, $1937: 195$, made the name a synonym of Targionia Signoret but this action was rejected by Ferris, 1937c: 33-34, and Balachowsky, 1951: 650, who considered it a synonym of Rhizaspidiotus MacGillivray. Brimblecombe, 1958: 74, restored the genus to valid 
status for a group of Australian species, noting a relation to Aspidiella Leonardi. Borchsenius and Williams, 1963, Brit. Mus. (Nat. Hist.) Ent. Bul. 13: 391-392, considered this group of species worthy of generic rank.

Remotaspis MacGillivray, 1921, The Coccidae, p. 311.

TYPE-SPECIES : Chionaspis dentilobis Newstead, 1910, by original designation and monotypy.

The author established this genus in the Diaspidini. Ferris, 1936a:26, considered the separation from Chionaspis Signoret valid. Hall, 1946a: 549, placed it in synonymy with Inchoaspis MacGillivray because of identity of type-species. See under Inchoaspis.

Reynvaania Reyne, 1954, Tijdschr. v. Ent. 97 : 234-235.

TYPE-SPECIES : Reynvaania gallicola Reyne, 1954, by original designation and monotypy.

The describer assigned this genus to Balachowsky's Eriococcidae. He noted more resemblance to Fulbrightia Ferris than to Olliffiella Cockerell, the other two eriococcid genera that cause galls on oaks. Hoy, 1963, New Zeal. Dept. Sci. and Indus. Res. Bul. 150: 13, accepted it in the Eriococcidae on the basis of the published description.

Rhizaecus Cockerell, 1899, Acad. Nat. Sci. Phila. Proc. 1899 : 265.

A lapsus for Rhizoecus Künckel d'Herculais.

Rhizaspidiotus MacGillivray, 1921, The Coccidae, p. 290.

TYPE-SPECIES : (Aspidiotus (Targionia) helianthi Parrott, 1899)=Aspidiotus dearnessi Cockerell, 1898, by original designation and monotypy.

The author established this genus in the Aspidiotini. Coccid workers, with the exception of Lindinger, who considered the name a synonym of Pseudodiaspis Cockerell, have accepted it as a valid genus but with a question as to its proper taxonomic position. Ferris, 1937a:34, assigned the genus to the Odonaspidini with a question; reversed himself, 1938a : SII-265, and reassigned it to the Aspidiotini. Balachowsky, 1948b : 268, placed it in Targionina, Aspidiotini, a position accepted by later workers.

"Rhizobinia Targioni 1867" Leonardi, 1920, Monografia delle Cocciniglie Italiane, p. 325.

A lapsus for Rhizobium Targioni-Tozzetti.

Rhizobium Targioni-Tozzetti, 1867, Soc. Ital. di Sci. Nat. Mem. 3 (3) : 23.

The author proposed this name with no specific name for the insect involved although he did present an illustration of a portion of derm of an adult female of the insect. He later, 1868:36, 1869:729, emended the name to Rhyzobium, at the same time placing it as a synonym of Lecanopsis "nob. gen. nov." The status of synonymy to Lecanopsis Targioni-Tozzetti has been continued by all subsequent writers on the group. 
Rhizobius Burmeister, 1835, Handb. der Ent. 2 (abt. 1) : 87.

TYPE-SPECIES : Rhizobius pilosellae Burmeister, 1835, by monotypy.

This genus was included in the list of aphid genera under the heading, "Aphis aut. Coccus Leon Duf.", followed by a description of the single included species and comment on its similarity to Coccus zeae maidis Dufour. There has been uncertainty as to the identity of the type-species. Lindinger considered it a coccid. However, workers in the Aphididae place the genus and species in that family.

Rhizobius Buckton, 1883, Monograph of the British Aphides 4: 181.

TYPE-SPECIES : Rhizobius jujubae Buckton, 1883, by monotypy.

This name was preoccupied by Rhizobius Burmeister, 1835 (Aphididae), and Rhizobius Agassiz, 1846 (emendation of Rhyzobius Stephens, 1829, Coleoptera). Rhizobius jujubae Buckton is a Drosicha Walker or something closely related. See Morrison, 1952: 76, for details.

Rhizococcus Signoret, 1875, Soc. Ent. de France Ann. (ser. 5) 5:16, 36.

TYPE-SPECIES : Rhizococcus gnidii Signoret, 1875, by monotypy.

The author presented this genus as very close to Eriococcus Targioni-Tozzetti and Acanthococcus Signoret in microscopic characters, but differentiated by habitat. Coccid workers have held varying views as to its status. Lindinger, 1933a: 107, considered the name of a synonym of Nidularia [of Lindinger, =Eriococcus auct.]. Ferris, 1955a : 94, and 1957c: 85, believing that the genus had been based on an immature insect, also considered the name a synonym of Eriococcus auct. Borchsenius, 1948: 501, and 1949: 351, maintained the validity of the genus and transferred to it a number of species formerly assigned to Eriococcus Targioni-Tozzetti. Danzig, 1962a: 839, accepted this interpretation and presented a revision with recharacterization of the genus, redescriptions of several species, and a key for differentiation of the species. Hoy, 1963, New Zeal. Dept. Sci. and Indus. Res. Bul. 150: 8, regarded Rhizococcus as a synonym of Eriococcus Targioni-Tozzetti.

Rhizoecus Künckel d'Herculais, 1878, Soc. Ent. de France Ann. (ser. 5) $8: 163$.

TYPE-SPECIES : Rhizoecus falcifer Kinckel d'Herculais, 1878, by monotypy.

The author established this genus for a root-infesting mealybug. Hambleton, 1946, reviewed it and related genera and added four new genera to the four already described in the group.

Rhizopulvinaria Borchsenius, 1952, Acad. Nauk SSSR Zool. Inst. Trudy 12: 297, 301-303.

TYPE-SPECIES: Rhizopulvinaria virgulata Borchsenius, 1952, by original designation.

The author placed this genus in the Pulvinariini, Coccinae. 
Rhodania Goux, 1935, Soc. Ent. de France Bul. (1934) 39: 291.

TYPE-SPECIES: Rhodania porifera Goux, 1935, by original designation and monotypy.

The author placed this genus in the Pseudococcini, Pseudococcidae, noting differentiation from the Pseudococcus Westwood group of species by absence of ostioles and from the Ripersia Signoret group by the character of the pores.

Rhodesaclerda McConnell, 1954, Md. Agr. Expt. Sta. Bul. A-75 (Tech.) : 110 .

TYPE-SPECIES : Rhodesaclerda combreticola McConnell, 1954, by original designation and monotypy.

The author placed this genus in the Aclerdidae with a question.

Rhodococcus Borchsenius, 1953, Ent. Obozr. 33 : 283.

TYPE-SPECIES : Rhodococcus rosaelutea Borchsenius, 1953, by original designation.

The author placed this genus in the Coccidae (str.), close to Eulecanium Cockerell.

Rhopaloaspis Del Guercio, 1903, Soc. Ent. Ital. Bul. (trimes. 3, 1902) $34: 188$.

TYPE-SPECIES: Leucaspis riccae Targioni-Tozzetti, 1881, by monotypy.

The author described this genus as very close to Leucaspis Targioni-Tozzetti but separated by absence of circumgenital glands. Subsequent workers have not accepted this separation but have placed the name as a synonym of Leucaspis.

Rhyzaecus Signoret, 1882, Soc. Ent. de France Ann. [Bul. Ent.] (ser. 6) $2: \mathrm{xxxv}$.

A lapsus for Rhizoecus Künckel d'Herculais.

Rhyzobium Targioni-Tozzetti, 1868, (separate) Soc. Ital. di Sci. Nat. Atti 11:36;1869,11:729.

An emendation of Rhizobium Targioni-Tozzetti, 1867:23, published as a synonym of Lecanopsis Targioni-Tozzetti, 1868: 36, $1869: 729$.

Ribesia Coubeaux, 1892, Soc. de Belgique Ann. 36: 82.

Lindinger, 1937: 195, listed this as a generic name which he assigned to synonymy with Pulvinaria Targioni-Tozzetti. After an examination of the Coubeaux list, we conclude that it merely had the appearance of a generic name due to the manner of printing and that it was intended to be a listing of the combination Pulvinaria ribesiae Signoret.

Ripersia Signoret, 1875, Soc. Ent. de France Ann. (ser. 5) 5: 335.

TYPE-SPECIES : Ripersia corynephori Signoret, 1875, by monotypy.

Due to the inadequacy of the original description which presented only the feature of 6 -segmented antenna in the adult female, and the fact that the type- 
species has not been found since its original collection, a valid redescription of the genus was not possible for many jears. However, a large number of species of mealybugs on Gramineae, or on roots of other plants, or in ants' nests were placed in the genus. Kiritchenko, 1936a: 130, sought to define the relation of the genus to Trionymus Berg and Pseudococcus Westwood, and determine distinctive characters permitting their separation. Proceeding from this point, Goux, 1940: 55-62, completed the arbitrary redefinition of the genus, basing it on characters of species grouped around tomlinii Newstead, and erected three new subgenera. Reyne, 1951a, after receiring remnants of the Signoret type material from the Vienna Museum, presented an extended description and discussion of the type-species based on a study of the preparations made from this material. Unfortunately, the slide used by Signoret for his observations has disappeared and the possibility exists that two species might have been involved, since Reyne's preparation showed an 8-segmented antenna.

Ripersiella Tinsley, 1899, Canad. Ent. 31:278.

TYPE-SPECIES : Ripersia rumicis Maskell, 1892, by subsequent designation of Cockerell, 1901j.

Cockerell, 1899m: 278, in a key, credited the name of the genus to Tinsley, and later, $1901 \mathrm{j}: 165$, further discussed the genus and designated the type-species. A group of morphologically allied root-infesting species of mealybugs, closely related to Rhizoecus Künckel d'Herculais, have been included under this name. Hambleton, 1946: 59-61, reviewed the genus and its relationships, transferred to it five species from Rhizoecus and described eight new species. Ferris, 1953a: 426, and Williams, 1962: 41, have not accepted the transfer of these species and have reassigned them to Rhizoecus.

Ritsemia Lichtenstein, 1879, Stettin. Ent. Ztg. 40 : 387; 1879, [Paris] Acad. des Sci. Compt. Rend. 88:870; 1879, Ann. and Mag. Nat. Hist. (ser. 5) $3: 455$.

TYPE-SPECIES : Ritsemia pupifera Lichtenstein, 1879, by monotypy.

This genus and species have remained unplaced by present-day coccidologists. On the basis of an opinion by Cockerell (in lit.), the species was assigned to the genus Ripersia Signoret in the Fernald Catalogue, 1903b: 119. We have examined three mica preparations labeled Ritsemia pupifera, sent to Professor Comstock by Lichtenstein in May 1882, and conclude therefrom that this is a valid genus.

Rizobius Passerini, 1863, Aphididae Italicae, p. 202.

A lapsus for Rhizobius Burmeister.

Rolaspis Hall, 1946, Roy. Ent. Soc., London, Trans. 97 : 499, 531. TYPE-SPECIES: Phenacaspis whitehilli Hall, 1946, by original designation.

The author referred this genus to the Diaspidini and noted differences from Phenacaspis Cooley and Cockerell, Tecaspis Hall and Voraspis Hall. Balachowsky, 1954e: 357 , assigned it to the Diaspidina, group II, chionaspiform. Borchsenius and Williams, 1963, Brit. Mus. (Nat. Hist.) Ent. Bul. 13: 366, confirmed its validity. 
Rosanococcus Kanda, 1934, Insect World 38: 311-312.

TYPE-SPECIES : Phenacoccus suwakoensis Kuwana and Toyoda, 1915, by original designation and monotypy.

Takahashi, 1958: 3, placed this name as a synonym of Coccura Šulc and suggested the identity of the type-species with Coccura ussuriensis (Borchsenius).

Rugaspidiotinus Balachowsky, 1953, Actualités Sci. et Indus., Ent. Appl. $1202: 749$.

TYPE-SPECIES: Rugaspidiotus circumdatus Ferris, 1938, by original designation.

The author placed this genus in the Odonaspidini, Rugaspidiotina, close to Rugaspidiotus MacGillivray.

Rugaspidiotus MacGillivray, 1921, The Coccidae, p. 393.

TYPE-SPECIES : Diaspis arizonica Cockerell, 1900, by original designation.

Recent workers have accepted this genus as valid. Balachowsky, 1953g: 750, 760, placed it in the Odonaspidini, Rugaspidiotina and listed Adiscodiaspis Marchal, 1909, among its synonyms. If these two genera are accepted as identical. Adiscodiaspis has priority and Rugaspidiotus would stand as the synonym.

Rugaspidis MacGillivray, 1921, The Coccidae, p. 449.

A lapsus for Rugaspidiotus MacGillivray.

Rugaspis Balachowsky, 1953, Actualités Sci. et Indus., Ent. Appl. $1202: 760$.

A lapsus for Rugaspidiotus MacGillivray.

Rugaspitiotus Balachowsky, 1953, Actualités Sci. et Indus., Ent. Appl. $1202: 761$.

A lapsus for Rugaspidiotus MacGillivray.

Rungaspis Balachowsky, 1949, Soc. Ent. de France Bul. 54 : 74.

TYPE-SPECIES : Rungaspis trabuti Balachowsky, 1949, by original designation and monotypy.

The author placed this genus in the Aspidiotini, Aspidiotina, related to Palinaspis Ferris.

Rupertsia Lichtenstein, 1877, Schweiz. Ent. Gesell. Mitt. 5 : 299.

A lapsus for Ripersia Signoret.

Russellaspis Bodenheimer, 1951, Ent. Ber. 13: 328.

TYPE-SPECIES: Asterodiaspis pustulans Cockerell, 1892, by original designation.

The author established this genus for Asterolecanium Group XI of Russell, 1941: 9. Borchsenius, 1960d: 154, accepted the genus in the Asterolecaniinae. 
Rutherfordia MacGillivray, 1921, The Coccidae, p. 306.

TYPE-SPECIES : Chionaspis malloti Rutherford, 1914, by original designation and monotypy.

Saccharicoccus Ferris, 1950, Atlas of the Scale Insects of North America (ser. 5) [v. 5]:21, 216.

TYPE-SPECIES : Dactylopius sacchari Cockerell, 1893, by original designation and monotypy.

The author established this genus for a distinctive grass-infesting pseudococcid having many characters in common with Trionymus Berg. Williams, 1962: 50, described a second species in the genus.

Saharaspis Balachowsky, 1951, Actualités Sci. et Indus., Ent. Appl. $1127: 567-568$.

TYPE-SPECIES : Hemiberlesia ceardi Balachowsky, 1928, by original designation and monotypy.

The author placed this genus in the Aspidiotini, Aspidiotina, related to Murataspis Balachowsky.

Saisettia Suomalainen, 1962, Ann. Rev. Ent. $7: 351,353$.

A lapsus for Saissetia Déplanche.

Saissetia Déplanche, 1859, Soc. Linn. de Normandie, Bul. 4 : 203-207. TYPE-SPECIES: (Saissetia coffeae Déplanche, 1859)=Lecanium coffeae Walker, 1852, by monotypy.

The descriptive material associated with the publication of this name covered a mealybug and possibly the coccid currently recognized in this country as Saissetia hemisphaerica (Targioni-Tozzetti). The association of the name Saissetia with a group of lecanine coccids having aereolated dorsal derm at maturity. along with other common characteristics, is so thoroughly established in entomological literature, especially in the economic field, that we believe it would be a great mistake to even consider reorientation of the application of the name because of confusion that exists in the original description.

The correct name to be applied to the type-species has also been uncertain. There is no great assurance that Déplanche examined specimens of the insect that is widely known today as S. hemisphaerica Targioni-Tozzetti, 1867, since there are apparently no recent records of the occurrence of this insect in Tahiti. However, coccid workers have more or less arbitrarily accepted the fact that coffeae Déplanche=coffeae Walker, is the same insect as hemisphaerica. Cockerell, 1894j: 71-72, suggested this identity and Laing, 1927: 39, reverted to the use of coffeae Walker in place of hemisphaerica. Williams, 1957:314, examined Walker's original material, confirmed its identity with the species known as hemisphaerica and concluded that Saissetia coffeae (Walker) should now be used in place of Saissetia hemisphaerica (Targioni-Tozzetti).

Sakalavaspis Mamet, 1954, Inst. Sci. de Madagascar, Mém. (1953) (Ser. E. Ent.) $4: 21,74$.

TYPE-SPECIES : Sakalavaspis perineti Mamet, 1954, by original designation.

The author assigned this genus to "Diaspididae with 'two-barred' ducts. Nonpupillarial." 
Sakaramyaspis Mamet, 1954, Inst. Sci. de Madagascar, Mém. (1953) (Ser. E. Ent.) $4: 21,78$.

TYPE-SPECIES: Sakaramyaspis beguei Mamet, 1953, by original designation and monotypy.

The author assigned this genus to the "Diaspididae with 'two-barred' ducts. Pupillarial." He noted its relationship to Porogymnaspis Green and closeness to Gymnaspis Newstead. Balachowsky, 1958b: 342, placed it in the Gymnaspidina.

Salaspis Hall, 1946, Roy. Ent. Soc., London, Trans. 97 : 535.

TYPE-SPECIES : Chionaspis tenuidisculus Newstead, 1920, by original designation and monotypy.

The author assigned this genus to the Diaspidini, probably close to Ledaspis Hall. Balachowsky, 1954e: 172, placed it in the Diaspidina, group II, chionaspiform. Lindinger, 1957: 552, assigned the type-species to Poliaspis Maskell.

Salicicola Lindinger, 1905, Zool. Anz. 29 : 253.

TYPE-SPECIES: Leucaspis kermanensis Lindinger, 1905, by monotypy.

The author established this as a "Sektion" of Leucaspis Targioni-Tozzetti. MacGillivray, 1921:262, raised it to subgeneric rank. Ferris, 1936a:23, accepted it as a valid genus. Balachowsky, 1953g: 901, placed it in the Leucaspidina.

Saliococcus Kanda, 1934, Insect World 38 :308-310.

TYPE-SPECIES : Dactylopius takae Kuwana, 1907, by original designation and monotypy.

The author placed this genus in the Pseudococcidae, resembling Phenacoccus Cockerell, but, 1935a : 70, recognized its identity with Heliococcus Šulc. In 1959: 179, he again presented Saliococcus in combination with tokyoensis sp. nov.

Sarulaspis Bodenheimer, 1953, Istanbul Univ. Facult. des Sci. Rev. Ser. B, $18: 6$.

A lapsus for Carulaspis MacGillivray.

Sasakia Kuwana, 1902, Calif. Acad. Sci. Proc. (ser. 3, Zool.) 3:47.

TYPE-SPECIES : Sasakia quercus Kuwana, 1902, by monotypy.

The author described this genus in the Margarodinae, Xylococcini. Cockerell. 1902q: 258, changed the name to Kuwania because of preoccupation of Sasakia in the Lepidoptera in 1896.

Sasakiaspis Kuwana, 1926, [Japan] Dept. Finance, Imp. Plant Quar. Serv. Tech. Bul. $4: 7$.

TYPE-SPECIES : Diaspis pentagona Targioni-Tozzetti, 1885, by original designation.

This name is currently accepted as a synonym of Pseudaulacaspis MacGillivray, 1921, with the same type-species.

Sassetia Dunham, 1954, [Bahia] Bol. Inst. Biol.1:68.

A lapsus for Saissetia Déplanche. 
Schizaspidiotus MacGillivray, 1921, The Coccidae, p. 456.

A lapsus for Schizaspis Cockerell and Robinson.

Schizaspis Cockerell and Robinson, 1915, Amer. Mus. Nat. Hist. Bul. $34: 423$.

TYPE-SPECIES : Schizaspis lobata Cockerell and Robinson, 1915, by monotypy.

The authors placed this genus in the Diaspinae but subsequent workers have referred it to the Aspidiotinae. Ferris, 1937c: 52, 56, accepted the genus as valid and figured the type-species.

Schizentaspidus Mamet, 1958, Mus. Roy. du Congo Belge [Tervuren] Ann. (n. s.) Sci. Zool. 4:421-422.

TYPE-SPECIES : Schizentapidus loranthi Mamet, 1958, by original designation.

The author placed this genus in the Aspidiotini, closely allied to Entaspidiotus MacGillivray.

Schizochlamidia Cockerell, 1899, Canad. Ent. 31:333, nomen nudum; 1899, Biol. Centr. Amer. 2, pt. $2: 15$.

TYPE-SPECIES: Schizochlamidia mexicana Cockerell and Parrott, 1899, by original designation and monotypy.

The author first presented this name with key characters but no included species. In the second citation he described the genus and trpe-species, and differentiated this lecanine genus from Inglisia Maskell, Platinglisia Cockerell, and Fairmairia Signoret.

Schizochlamydia Borchsenius, 1957, Akad. Nauk SSSR Zool. Inst. (n. s. 66) $9: 47$.

A lapsus for Schizochlamidia Cockerell.

Schizochlamys Cockerell, 1900, Biol. Centr. Amer. 2 (pt. 2 ) : 15.

The author substituted this name for his Schizochlamidia because "that name belongs to a genus of Algae." Lindinger, 1937: 195, listed Schizochlamidia Cockerell as a synonym of this name. Howerer, Schizochlamidia, published in Nor. 1899, definitely predates the December publication of Schizochlamys and therefore has priority.

Schizotargionia Balachowsky, 1951, Actualités Sci. et Indus., Ent. Appl. 1127 : 632, 644-645.

TYPE-SPECIES : Aspidiotus (Aonidiclla) arthrophyti Archangelskaia, 1931, by original designation and monotypy.

The author placed this genus in his Targionina, near Targionia Signoret. He noted the close correspondence to Targaspidiotus MacGillivras, the trpe-species of which he included in his ner genus. If yuccarum Cockerell is established to be congeneric with arthrophyti Archangelskaia, Schizotargionia will stand as a srnonym of Targaspidiotus. See under Targaspidiotus for further details. 
Scleromytilus Hall, 1946, Roy. Ent. Soc., London, Trans. 97 : 71.

TYPE-SPECIES : Scleromytilus hargreavesi Hall, 1946, by original designation and monotypy.

The author placed this genus in the Diaspidini, noting that the affinities of the genus were not clear, but some resemblances to Phaulomytilus Leonardi, Aonidomytilus Leonardi, and Mitulaspis MacGillivray were evident.

Sclerosococcus McKenzie, 195̌, Pan-Pacific Ent. 34: 169-170.

TYPE-SPECIES : Sclerosococcus ferrisi McKenzie, 1958, b5 original designation and monotypy.

The author assigned this genus to the Asterolecaniidae.

Sclopetaspis MacGillivray, 1921, The Coccidae, p. 307.

TYPE-SPECIES : Chionaspis laniger Newstead, 1920, by original designation.

This genus of the Diaspidini was accepted as ralid by Ferris, 1937d: 101, and BalachowskJ, 195łe: 171, who placed it in the Diaspidina, group II, chionaspiform.

Scobinaspis MacGillirray, 1921, The Coccidae, p. 274.

TYPE-SPECIES : Mytilaspis serrifrons Leonardi, 1898, bj original designation and monotypy.

The author placed this genus in the Lepidosaphini. Ferris, 1937: SI-131, considered Scobinaspis dentata Hoke, which he made type-species of Velataspis Ferris, not especially related to serrifrons Leonardi. Howerer, Balachowsky, 1954e: 91 , placed serrifrons Leonardi in Velataspis, but without displacing the name Velataspis, a necessity in order to make the transfer valid, since Scobinaspis precedes Velataspis by 16 jears.

Scrupulaspis MacGillivray, 1921, The Coccidae, p. 274.

TYPE-SPECIES : Mytilaspis intermedia Maskell, 1891, by original designation.

The author placed this genus in the Lepidosaphini. Borchsenius and Williams, 1963, Brit. Mus. (Nat. Hist.) Ent. Bul. 13: 370, accepted the genus and placed it closest to Lepidosaphes Shimer.

Scutare Brittin, 1915, New Zeal. Inst. Trans. and Proc. $47: 158$.

TYPE-SPECIES : Scutare fimbriata Brittin, 1915, by monotypy.

The author placed this genus tentatively in the Conchaspinae. This placement was accepted by MacGillirray, 1921: 215, and Balachorsky, 1948b: 259, but rejected by Silvestri, 1939: 860. Green, 1916d: 51, transferred the typespecies to Rhizococcus Signoret as did Mamet, 1954b: 193 . Hor, 1962: 173, gare Scutare valid status in the Eriococcidae.

Scytalaspis Ferris, 195̌

TYPE-SPECIES : Scytalaspis quadriclavata Ferris, 1955, by original designation and monotypy. [Presented as Clavataspis quadriclarata, new speciesan obvious elror.]

The author referred this genus to the Lepidosaphes Shimer series of the Diaspidinae, resembling the genus Andaspis MacGillirray in many respects. 
Scythia Kiritchenko, 1938, Konowia 16:229.

TYPE-SPECIES: Scythia craniumequinum Kiritchenko, 1938, by monotypy.

The author placed this genus in the Lecaniinae, near Eriopeltis Signoret. Borchsenius, $1957: 178$, assigned it to the Filippinae.

Seabrina Neves, 1943, Lisboa Univ. Arq. do Mus. Bocago 14: 1.

TYPE-SPECIES: Seabrina cistorum Neves, 1943, by original designation and monotypy.

The author placed this genus in the Kermidae but noted a certain similarity to Puto Signoret and Echinococcus Balachowsky. Gómez-Menor, 1957: 79-85, redescribed the genus and type-species and assigned them to the Pseudococcidae.

Seissetia Abrahao and Mamprim, 1958, O’Biológico 24:268.

A lapsus for Saissetia Déplanche.

Selenaspidiotus Thiem and Gerneck, 1934, Arb. über Physiol. u. Angew. Ent. 1: 230.

This name was presented in a phylogenetic "tree" with no species association. We believe that it must stand as a nomen nudum. Lindinger, 1937: 195, listed it as a synonym of Selenaspidus Cockerell.

Selenaspidius Kloet and Hincks, 1945, A Check List of British Insects, p. 75.

A lapsus for Selenaspidus Cockerell.

Selenaspidus Cockerell, 1897, U.S. Dept. Agr., Div. Ent., Tech. Ser. $6: 14$.

TYPE-SPECIES : A[spidiotus] articulatus Morgan, 1889, by original designation and monotypy.

The author presented this as a subgenus of Aspidiotus Bouché. It is currently considered a valid genus in the Selenaspidina, Aspidiotini.

Selenaspis Leonardi, 1897, Riv. di Patol. Teg. 5: 375 ; 1898, (1897) $6: 50(210)-51(211)$.

This is a lapsus or an unnecessary emendation of Selenaspidus Cockerell, and has not been accepted by other coccidologists.

Selenediella Mamet, 1958, Mus. Roy. du Congo Belge [Tervuren] Ann. (n.s.) Sci. Zool.4:424.

TYPE-SPECIES: Hemiberlesia mekenzici Takahashi, 1951, by original designation and monotypy.

The author placed this genus in the Aspidiotini, closely related to selenaspidus Cockerell and with certain resemblances to Aonidiclla Berlese and Leonardi. 
Selenomphalus Mamet, 1958, Mus. Roy. du Congo Belge [Tervuren] Ann. (n.s.) Sci. Zool.4:426.

TIPE-SPECIES: Aspidiotus euryae Takahashi, 1931, by original designation and monotyps.

The author placed this genus in the Aspidiotini, closely allied to Neoselenaspidus Mamet, and in certain characters related to Chrysomphalus Ashmead and allied genera.

Semelaspidus MacGillivray, 1921, The Coccidae, p. 393.

TYPE-SPECIES : (Aspidiotus (Chrysomphatus) cistuloides Green, 1905) =Aspidiotus artocarpi Green, 1896, by original designation.

The author placed this genus in the Aspidiotini. Williams, 1957a: 31-36, revierred the genus and considered it ralid in the Pseudaonidina, closest to Duplaspidiotus MacGillivray.

Separaspis MacGillirray, 1921, The Coccidae, p. 390.

TYPE-SPECIES: Furcaspis proteae Brain, 1918, by original designation and monotyps.

The author placed this genus in the Aspidiotini. Lindinger, 1937: 195, considered the name a synonym of Furcaspis Lindinger. The genus was accepted as possibly valid though close to Furcaspis by Ferris, 1938: 43. Balachowsky, 1958b : 249-255, placed it in the Furcaspidina.

Serrataspis Ferris, 195̌, Microentomology $20: 31$.

TYPE-SPECIES : Serrataspis maculata Ferris, 1955, by original designation and monotypy.

The author placed this genus as belonging to the Diaspis Costa series in the Diaspididae.

Serrolecanium Shinji, 1935̆, Oỹo-Dobutsugaku Zasshi [Jap. Soc. Appl. Zool.] 7: 106.

TYPE-SPECIES: Serrolecanium bambusae Shinji, 1935, by monotsps.

The author erected the Serrolecaniinae for this genus, but after a study of new material, 1935b: 770, placed it in the Lecaniinae. Kanda, 1936, Insect World $40: 5$, and Siraiwa, 1939:68, noted the synonsmy of bambusae with Antonina tobae Kurana. Ferris, 1950a: 71, placed the genus in the Pseudococcidae near Antonina Signoret.

Signoretia Targioni-Tozzetti, 1868, (separate) Soc. Ital. di Sci. Nat. Atti 11:34;1869, 11:727.

TYPE-SPECIES: (Signoretia clypeata Stål, 1869)=Aspidiotus (?) luzulae Dufour, 1864.

This name was preoccupied by Signoretia Stål, 1859, in the Hemiptera and was replaced by Luzulaspis Cockerell, 1902. 


\section{MISC. PUBLICATION 1015 , U.S. DEPT. OF AGRICULTURE}

Signoretia Kraatz, 1888, Deut. Ent. Ztschr. $32: 176$.

TYPE-SPECIES: Westwoodia perrisii Signoret, 1875, by substitution of Signoretia for Westwoodia Signoret.

The author proposed this name to replace preoccupied Westwoodia Signoret. Later in the same volume, 1888a: 360, recognizing that Signoretia was invalid because of use in the Hemiptera in 1859 by Stål, he presented the name Bergrothia as a substitute. Reitter, 1898: 54, having noted the use of Bergrothia in the Coleoptera in 1884, suggested Bergrothiella to replace Bergrothia Kraatz, 1888. This substitution has not been accepted. Berg, 1899: 78, apparently in ignorance of Reitter's action, presented: "Trionymus nov. nom. pro Signoretia Kraatz 1888." Trionymus Berg is currently accepted as the valid name for this zoological unit.

Signorettia Targioni-Tozzetti, 1869, Soc. Ital. di Sci. Nat. Atti 11: 699.

A lapsus for Signoretia Targioni-Tozzetti.

Silvestraspis Bellio, 1929, Portici, R. Ist. Super. Agr., Lab. Zool. Gen. e Agr. Bol. 22 : 159.

TYPE-SPECIES : Silvestraspis sinensis Bellio, 1929, by original designation and monotypy.

The author placed this genus in the Diaspinae near Leucaspis Targioni-Tozzetti. Lindinger, 1931a: 89, listed the name as a synonym of Cryptoparlatorea Lindinger, and 1934:26, 1937:196, of Apteronidia Berlese. Other workers have accepted the genus as valid. Balachowsky, 1958b:315, assigned it to his Parlatorina. Takahashi, 1942b : 46-47, recorded the type-species as a synonym of "S. uberifera (Ldgr.)."

Sinaidiaspis Bodenheimer, 1951, Ent. Ber. 13 : 329.

TYPE-SPECIES : Diaspis capperidis Bodenheimer, 1929, by original designation and monotypy.

The author placed this genus in the Diaspidinae and noted differences from Pseudodiaspis Cockerell, Neosignoretia MacGillivray, and Howardia Leonardi.

Sinistraspis MacGillivray, 1921, The Coccidae, p. 309.

TYPE-SPECIES : Chionaspis unilateralis Newstead, 1913, by original designation and monotypy.

The author placed this genus in the Diaspidini. Coccid workers, with the exception of Lindinger, have accepted it as valid. Balachowsky, 1954e:171, placed it in the Diaspidina, group II, chionaspiform.

Sishanaspis Ferris, 1952, Microentomology $17: 6$.

TYPE-SPECIES: Sishanaspis quercicola Ferris, 1952, by original designation and monotypy.

The author placed this genus in the Parlatoria Targioni-Tozzetti series of the Diaspidini. Balachowsky, 1958b : 315, assigned it to his Parlatorina. 
Sishania Ferris, 1950, Microentomology 15 : 12-13.

TYPE-SPECIES : Sishania nigropilata Ferris, 1950, by original designation and monotypy.

The author placed this genus in the Margarodidae, Monophlebinae, Drosichini, most closely related to Drosicha Walker and Drosichiella Morrison.

Sisyrococcus Hoy, 1962, New Zeal. Dept. Sci. and Indus. Res. Bul. $146: 181$.

TYPE-SPECIES : Rhizococcus intermedius Maskell, 1891, by original designation.

The author placed this genus in the Eriococcidae.

Situlaspis MacGillivray, 1921, The Coccidae, p. 311.

TYPE-SPECIES : Pseudodiaspis condaliae Ferris, 1919, by original designation and monotypy.

The author placed this genus in the Diaspidini. Lindinger, $1937: 196$, rejected its separation from Pseudodiaspis Cockerell. It was accepted as valid by Ferris, 1937 : SI-68, 120, and Balachowsky, 1954e:167, who placed it in the Diaspidina, group I, diaspiform.

Solenaspidus Hollrung, 1914, Jahresber. über Pflanz. (for 1912) 15: $338,441$.

A lapsus for Selenaspidus Cockerell.

Solenococcus Cockerell, 1899, Ill. Nat. Hist. Survey Bul. 5 : 392.

TYPE-SPECIES : Solenophora fagi Maskell, 1890, by subsequent designation of Fernald, 1903b : 58.

The author proposed this name as a substitute for Solenophora Maskell, 1890, on grounds of preoccupation by two prior publications of the name Solenophorus. Cockerell (in lit., 1922) reversed himself on this substitution and expressed the opinion that Solenophora is "validly constituted on the two-letter rule." At the moment the matter is not of first importance since both names are currently placed in synonymy under Cerococcus Comstock (see Ferris, 1955a:31), but a critical study of all the elements now included in Cerococcus might develop a basis for splitting the genus as currently accepted, and the reestablishment of Solenophora-Solenococcus as a valid segregate.

Solenophora Maskell, 1890, New Zeal. Inst. Trans. and Proc. (1889) $22: 139$.

TYPE-SPECIES: Solenophora fagi Maskell, 1899, by identity of Solenophora with Solenococcus Cockerell, 1899.

This name is currently regarded as preoccupied and replaced by Solenococcus Cockerell, 1899, and as belonging in synonymy under Cerococcus Comstock. 
Spatheaspis Leonardi, 1897, Riv. di Patol. Veg. $6: 109,115$.

TYPE-SPECIES: Aspidiotus secretus Cockerell, 1896, by monotypy.

The author presented this name as a substitute for Odonaspis Leonardi, which he believed to be preoccupied by Odonaspis in Pisces. He was in error in this since the name proposed by Agassiz in 1835 was Odontaspis. Spatheaspis is currently accepted as a synonym of Odonaspis.

Spermococcus Giard, 1894, Soc. Ent. de France Ann. [Bul. Ent.] (1893) 62: cxcix.

TYPE-SPECIES : Spermococcus fallax Giard, 1894, by monotypy.

The author noted that in general appearance this genus was a "Lecanite."

The name is currently accepted as a synonym of Lecanopsis Targioni-Tozzetti. Lindinger, 1935: 135, placed fallax as a synonym of radicumgraminis Fonscolombe, but Borchsenius, 1957 : 11, retained it, calling the type-species Lecanopsis fallax (Giard).

Sphaeraspis Giard, 1894, Soc. de Biol. [Paris] Compt. Rend. (ser. 10, v. 1) $46: 712$.

TYPE-SPECIES : Margarodes vitium Giard, 1894, by monotypy.

The author presented this as a subgenus of Margarodes Guilding. The name is currently placed in synonymy with Margarodes.

Sphaerococcopsis Cockerell, 1899, Acad. Nat. Sci. Phila. Proc., p. 262.

TYPE-SPECIES : Sphaerococcopsis inflatipes Maskell, 1893, by original designation and monotypy.

Morrison and Morrison, 1922 : 32, redescribed this genus and considered it possibly eriococcine. Hoy, 1963, New Zeal. Dept. Sci. and Indus. Res. Bul. 150: 14, included it in the Eriococcidae.

Sphaerococcus Maskell, 1892, New Zeal. Inst. Trans. and Proc. (1891) $24: 39$.

TYPE-SPECIES : Sphaerococcus casuarinae Maskell, 1892, by monotypy.

Ferris, 1919 : 249, redescribed the genus, placing it in the pseudococcine group of genera, very close to Antonina Signoret.

Sphaerocopsis Balachowsky, 1948, Actualités Sci. et Indus., Ent. Appl. 1054: 257.

A lapsus for Sphaerococcopsis Cockerell.

Sphaerolecanium Sule, 1908, Ent. Monthly Mag. 44: 36.

TYPE-SPECIES : Coccus prunastri Fonscolombe, 1834, by original designation and monotypy.

The author established this genus on characters of the male, presenting it as one of four genera into which he divided Lccanium (sensu Signoret). In 1932: 47 , he reduced its status to that of a subgenus. Schmutterer, 1952: 552, Borchsenius, 1957 : 322, Gómez-Menor, 1958: 26, and others have accepted Sphacrolecanium as a valid genus. 
Sphaerolecanium Leonardi, 1908, (non Sulc, 1908), Portici R. Scuola Super. di Agr. Lab. Zool. Gen. e Agr. Bol. 3 : 180-181.

TYPE-SPECIES : Chermes emerici Planchon, 1864, by monotypy.

Silvestri, in Leonardi, 1920 : 312, said that the name of this genus must be considered a synonym of Eulecanium Cockerell and that of the type-species, a synonym of Eulecanium coryli or variety.

Spheralecanium Chorbadzhiev, 1939, Izv. B'lgarsk. Ent. Druzh. for 1938 [Sofia] 10: 89.

A lapsus for Sphaerolecanium Leonardi.

Spilococcus Ferris, 1950, Atlas of the Scale Insects of North America (ser. 5) [v. 5]:22, 219.

TYPE-SPECIES: Dactylopius gutierreziae Cockerell, 1896, by original designation.

The author established this genus as a segregate from Pseudococcus Westwood. Subsequent coccid workers have accepted it as valid.

Spinaspidiotus MacGillivray, 1921, The Coccidae, pp. 390, 428.

TYPE-SPECIES : Aspidiotus fissidens Lindinger, 1909, by original designation.

The author placed this genus in the Aspidiotini. Recent coccid workers have accepted it as valid as regards the type-species, but have rejected the additional inclusions. Balachowsky, 1958b : 218, placed it in the Aspidiotini, Aspidiotina, close to Schizaspis Cockerell and Robinson and with some affinity to Hemiberlesia Cockerell.

Spinococcus Borchsenius; Kiritchenko, 1931, Inst. Zashch. Rast. Plant Protect. [Leningrad] (1930) 7: 314, nomen nudum; Kiritchenko, 1936, Rev. d'Ent. de l'URSS (1935) $26: 156$; Borchsenius, 1948, Akad. Nauk SSSR Dok. (n.s.) 61: 953; Borchsenius, 1949, Akad. Nauk SSSR Zool. Inst. (n.s. 38) 7: 203-204.

TYPE-SPECIES: Acanthococcus marrubii Kiritchenko, 1936, by designation of Borchsenius, 1949 : 203-204.

Kiritchenko, 1931: 314, presented Spinococcus marrubii Kiritchenko with collection and biological notes but no descriptive information. In 1936a: 156-158, the same species appeared as Acanthococcus marrubii n. sp., with full description and figures. Borchsenius, 1948a: 953, noted the genus as: "Spinococcus Kir., 1930 (=Acanthococcus Kir. 1936)" in his revision of the genus Phenacoccus Cockerell, and, 1949: 203-204, validated Spinococcus by designating Acanthococcus marrubii Kiritchenko as type-species. Balachowsky, 1953: 282, placed Spinococcus in synonymy with Synancanthococcus Morrison, but Danzig, 1960 : 178, rejected this action and considered the two genera distinct. Recent workers have accepted the validity of Spinococcus.

$208-496-66-13$ 
Stachycoccus Borchsenius, 1962, Akad. Nauk SSSR, Zool. Inst. Trudy 30: 240.

TYPE-SPECIES: Stachycoccus caulicola Borchsenius, 1962, by original designation and monotypy.

The author placed this genus in the Phenacoccini, Pseudococcidae, close to Heterococcus Ferris and Rhodania Goux.

Steatococcus Ferris, 1921, Stanford Univ. Pubs., Univ. Ser., Biol. Sci. 1:69.

TYPE-SPECIES : Palaeococcus morrilli Cockerell, 1914, by original designation.

The author associated in this genus, three species of monophleboid coccids previously assigned to Palaeococcus Cockerell and two described as new. Morrison, 1928: 214, placed the genus in the Iceryini and noted that the included species were readily segregated, morphologically and geographically, into three groups, possibly of subgeneric rank.

Stegococcus Hoy, 1962, New Zeal. Dept. Sci. and Indus. Res. Bul. $146: 186$.

TYPE-SPECIES : Stegococcus oleariae Hoy, 1962, by original designation and monotypy.

The author placed this genus in the Eriococcidae closely associated with Eriococcus Targioni-Tozzetti.

Steingelia Nassanov, 1908, Mus. Zool. de l'Acad. Imp. Sci. St. Petersbourg Ann. 13: 345 .

TYPE-SPECIES : Steingelia gorodetskia Nassanov, 1908, by original designation and monotypy.

The author placed this genus closest to Xylococcus Löw. Morrison, 1928: 5354, associated it with stomacoccus Ferris in the Steingeliinae, Margarodidae.

Stemmatomerinx Ferris, 1950, Atlas of the Scale Insects of North America (ser. 5) [จ. 5]: 21, 245.

TYPE-SPECIES : Stermmatomerinx decorata Ferris, 1950, by original designation and monotypy.

The author placed this genus in the Phenacoccus Cockerell series of the Pseudococcidae, somewhat like Synacanthococcus Lindinger.

Stenolecanium Takahashi, 1959, Kontyu 27 : 74.

TYPE-SPECIES : Stenolecanium esakii Takahashi, 1959, by original designation and monotypy.

The author placed this genus in the Coccidae (str.) related to Luzulaspis Cockerell and Parafairmairia Cockerell.

Stictococcus Cockerell, 1903, Canad. Ent. 35: 64.

TYPE-SPECIES: Stictococcus sjostedti Cockerell, 1903, by monotypy.

The author established this as an aberrant genus of the Lecaniinae. Coccid workers hare not questioned the validity of the genus but its proper srstematic 
position has not been established with certainty. Sanders, 1906: 7, included it in the same subfamily as the author but under the name Coccinae. Newstead, 1908a : 150-151, placed it tentatively in the Margarodinae, near Xylococcus Löw. Lindinger, $1913 ; 63,91$, erected the Stictococcinae for it. Silvestri, 1915a: 388, accepted the last action, considering that the genus was in no way related to the Margarodidae, and was distinct though with affinity to the Lecaniinae. Balachowsky, 1942: 42, raised it to family rank as the Stictococcidae. Ferris, 1957 b : 65-66, was uncertain as to where to place this family.

Stictolecanium Cockerell, 1902, Ann. and Mag. Nat. Hist. (ser. 7) 9: 452 .

TYPE-SPECIES : Lecanium ornatum Hempel, 1900, by original designation and monotyps.

The author placed this genus in the Lecaniinae, allied to Mesolecanium Cockerell.

Stigmacoccus Hempel, 1900, Rev. Mus. Paulista [Sao Paulo] 4: 379, 399.

TYPE-SPECIES : Stigmacoccus asper Hempel, 1900, by original designation and monotypy.

Morrison, 1927: 100, established the Stigmacoccini in the Xylococcinae for this margarodid genus. He considered that Cockerell, 1902q: 233, had incorrectly associated it with Perissopneumon Newstead.

Stigmatococcus Lindinger, 1937, Ent. Jahrb. $46: 196$.

An emendation of Stigmacoccus Hempel.

Stomacoccus Ferris, 1917, Canad. Ent. 49 : 375.

TYPE-SPECIES : Stomacoccus platani Ferris, 1917, by original designation and monotypy.

The author referred this genus to the Xylococini, Margarodinae. Morrison, 1928: 54, placed it in the Steingeliini, Steingeliinae, Margarodidae.

Stomatococcus Lindinger, 1937, Ent. Jahrb. $46: 196$.

An emendation of Stomacoccus Ferris.

Stotzia Marchal, 1906, Soc. Ent. de France Bul. 9 : 143.

TYPE-SPECIES : Stotzia striata Marchal, 1906, by monotypy.

The author placed this genus in the "Lecanides, near Lichtensia and Philippia." The synonymy of striata with Filippia ephedrae (Newstead) listed by Lindinger, $1912 \mathrm{~b}:$ 140, was rejected by Balachowsky, 1929a : 309. Borchsenius, 1957: 183, accepted the genus as valid in the Filippiinae, Coccidae (str.).

Stramenaspis Ferris, 1937, Atlas of the Scale Insects of North America (ser. 1) [v.1]:SI-126.

TYPE-SPECIES : Leucaspis kelloggi Coleman, 1903, by original designation and monotypy.

The author placed this genus in the Diaspidini and noted a faint suggestion of relationship with Lineaspis MacGillivray. Balachowsky, 1954e: 16, 265, placed it near Kuwanaspis MacGillivray in the Diaspidina, group II, chionaspiform. 
Stringaspidiotus MacGillivray, 1921, The Coccidae, p. 393.

TYPE-SPECIES: Aspidiotus (Pseudaonidia) curculiginis Green, 1904, by original designation.

The author placed this genus in the Aspidiotini. Lindinger, 1937: 196, and Ferris, 1938a : SII-230, considered the name a synonym of Furcaspis Lindinger.

Suareziella Mamet, 1954, Inst. Sci. de Madagascar, Mém. (1953) (Ser. E. Ent.) $4: 14,47-48$.

TYPE-SPECIES : Suareziella montana Mamet, 1954, by original designation and monotypy.

The author placed this genus in the Coccidae (str.) and compared it with Pulvinaria Targioni-Tozzetti, Protopulvinaria Cockerell, Coccus Linnaeus, and Lecanium Burmeister.

Suturaspis Lindinger, 1906, Jahrb. der Hamburg. Wiss. Anst. (1905) 23 Beih. 3: 26.

TYPE-SPECIES: Leucaspis pistaciae Lindinger, 1906, by subsequent designation of MacGillivray, 1921: 268.

The author presented this as one of two divisions of "Sektion" Euleucaspis of the genus Leucaspis Targioni-Tozzetti but, 1937: 196, listed the name as a synonym of Leucodiaspis Signoret. Ferris, 1936a: 26, considered it "probably worthy of separation from Leucaspis." Balachowsky, 1953g: 882, placed Suturaspis as a synonym of Salicicola Lindinger.

Symeria Green, 1929, Bul. Ent. Res. $19: 380$.

TYPE-SPECIES: (Lepidosaphes epiphytidis (Maskell) of Green, 1929)= Symeria zealandica Morrison and Morrison, n. sp., by original designation and monotypy.

The author established this genus for a species identified by him as Lepidosaphes epiphytidis (Maskell) but the description and figure presented do not agree with type specimens of Maskell's epiphytidis. We believe that the genus Symeria must have for its type-species the species on which the author based his generic description, to which we herewith assign the name zealandica. The author described this diaspidine genus as resembling Lepidosaphes Shimer in structure of the male and female puparia but differing in microscopic characters.

Synacanthococcus Morrison, 1920, Philippine Jour. Sci. 17: 166.

TYPE-SPECIES: Synacanthococcus bispinosus Morrison, 1920, b5 original designation and monotypy.

The author placed this pseudococcine form as most closely related to Tylococcus Newstead.

Synanthococcus Lindinger, 1937, Ent. Jahrb. $46: 196$.

A lapsus for Synacanthococcus Morrison. 
Syngenaspis Sulc, 1895, [Prague] K. Böhmisch. Gesell. der Wiss. Sitzberg. (1895) pt. 2, no. $49: 2$.

TYPE-SPECIES: Syngenaspis parlatoriae Šulc, 1895, by original designation and monotypy.

The author presented this genus as closely allied to Parlatoria Targioni-Tozzetti. Subsequent workers have recognized and emphasized this close relationship. McKenzie, 1945: 85-86, accepted the genus, restricted to the type-species, as valid. Balachowsky, $1953 \mathrm{~g}: 820-821$, concurred in this opinion and placed it in his Parlatorini, Parlatorina.

Syphaerococcus Lindinger, 1958, Beitr. z. Ent. 8:371.

A lapsus for Sphaerococcus Maskell.

Syrmococcus Ferris, 1953, Atlas of the Scale Insects of North America $6: 472$.

TYPE-SPECIES : Pseudantonina spirapuncta Lobdell, 1930, by original designation.

The author placed this genus in the Pseudococcidae, in many respects close to Discococcus Ferris but not allied to Pseudantonina Green.

Tachardia Blanchard, 1886, in Signoret, Soc. Ent. de France Ann. [Bul. Ent.] (ser. 6) 6: lxii.

TYPE-SPECTES: Cocous lacca Kerr, 1782, by substitution of Tachardia for Carteria Signoret.

This name was offered as a substitute for Carteria Signoret, 1874, preoccupied by use in the Protozoa in 1866. The lac insect appeared in literature as Tachardia lacca for more than 40 years subsequently. The priority of the use of Laccifer Oken over Tachardia for this insect, noted first by Kirkaldy, 1906, received little notice until Cockerell, 1924, repeated and emphasized the fact. Chamberlin, 1925, formally accepted the substitution of Laccifer for Tachardia, together with the change of family name to Lacciferidae, and most coccid workers since that date have done the same.

Tachardiella Cockerell, 1901, Entomologist 34: 249.

TYPE-SPECIES : Tachardia cornuta Cockerell, 1894, by original designation.

The author presented this as a subgenus of Tachardia Blanchard. Chamberlin, 1923: 174, raised it to generic status and divided it into two subgenera. Balachowsky, 1950: 9, placed it in the Lacciferini, Lacciferinina.

Tachardina Cockerell, 1901, Entomologist 34: 249.

TYPE-SPECIES : Tachardia albida Cockerell, 1901, by original designation and monotypy.

The author presented this as a subgenus of Tachardia Blanchard. Chamberlin, 1923: 199, accepted it as of generic rank and separated it into two subgenera. Balachowsky, 1950: 9, placed it in the Tachardini, Tachardinina. 
Takahashia Cockerell, 1896, Psyche (sup.) 7:20.

TYPE-SPECIES : Pulvinaria (Takahashia) japonica Cockerell, 1896, by original designation and monotypy.

The author presented this as a subgenus of Pulvinaria Targioni-Tozzetti. Steinweden, 1929: 240-241, accepted it as a valid genus for the type-species, but considered jaliscensis T. \& W. Cockerell, 1902t, not congeneric. Lindinger, 1937: 196, and Borchsenius, 1957 : 288, accepted the genus.

Takahashiaspis Takagi, 1961, Insecta Matsumurana 24:92, 94.

TYPE-SPECIES: Takahashiaspis macroporana Takagi, 1961. by original designation and monotypy.

The proposer noted that this genus of Diaspidini is very distinct although related to Neochionaspis Borchsenius, Contigaspis MacGillivray, Gadaspis Hall, and Paragadaspis Kaussari and Balachowsky.

Takahashicoccus Kanda, 1959, Kontyu $27: 239$.

TYPE-SPECIES : Heliococcus takahashii Kanda, 1935, by original designation and monotypy.

The author placed this genus in the Pseudococcidae, closely allied to Heliococcus Šulc.

Talla von Heyden, 1860, Correspondenzbl. f. Sammler von Insekten 1: 90 .

TYPE-SPECIES: Lecanium quercus Reaumur, 1860)=Coccus quercus Linnaeus, 1758 [Kermes quercus (L.) of current usage], by monotypy.

Lindinger, 1933a: 143, placed this as a valid genus, with Kermes Boitard a synonym of the name, but this opinion has not been accepted by most coccid workers. The critical point in the problem is the character of the Latreille, 1798: 113, use of the name Kermes. Our opinion is that he presented it as a group common name, which did not invalidate its later usage by Boitard, 182S, in a technical sense. We place Talla von Heyden, 1860, in synonymy with Kermes Boitard, 1828.

Tallaspidiotus Balachowsky, 1958, Mus. Roy. du Congo Belge [Tervuren] Ann. (n. s.) Sci. Zool. $4: 249$.

A lapsus for Tollaspidiotus MacGillivray.

Targaspidiotus MacGillivray, 1921, The Coccidae, p. 392.

TYPE-SPECIES : Aspidiotus yuccarum Cockerell, 1898, by original designation.

The author placed this genus in the Aspidiotini. Lindinger, 1937: 197, and Ferris, $1937 \mathrm{c}: 52,56$, considered the name a synonym of Targionia Signoret. Borchsenius, 1952: 263, rejected this synonymy and accepted the validity of the genus but suggested the possible need to separate, as a new unit, the palearctic species, a group morphologically close to each other and with similar host and environmental relations. Balachowsky, 1951: 644, noted the Ferris rejection of Targaspidiotus but recognized the merit of a division of Targionia and proposed the genus Schizotargionia corresponding in general concept to the MacGillivray genus. However, he cited arthrophyti Archangelskaia as type-species of his genus 
and included in it yuccarum Cockerell and halophila Balachowsky. If a restudy should confirm yuccarum as congeneric with arthrophyti, then Echizotargionia would stand as a synonym of Targaspidiotus. If, on the other hand, yuccarum Cockerell were excluded, Schizotargionia might well care for the group of palearctic species as suggested by Borchsenius, and Targaspidiotus, with typespecies yuccarum Cockerell, would include the Nearctic species.

Targionia Signoret, 1869, Soc. Ent. de France Ann. (1869) (ser. 4) $8: 862 ; 1869$, (ser.4) $9: 99 ; 1870$, (ser.4) $10: 105$.

TYPE-SPECIES: Targionia nigra Signoret, 1869, by original indication and monotypy.

This genus did not meet with immediate acceptance. Comstcck, 1883: 453, rejected it as inseparable from Aspidiotus Bouché, and Cockerell, 1893d: 8, treated it as a subgenus of the latter. However, Leonardi, 1900: 343 , considered it valid, as have most subsequent workers, although the zoological concept of the unit has not been clear. All sorts of unrelated species were referred to it over the years by various authors. Ferris, 1943a, presented a detailed review of the genus and restricted the included species to six definitely assigned, and two more placed tentatively. Balachowsky, 1948b:268, placed the genus in his Targionina.

Targionidea MacGillivray, 1921, The Coccidae, p. 393.

TYPE-SPECIES: Targionia (?) campylanthi Lindinger, 1911, by original designation.

The author placed this genus in the Aspidiotini. Lindinger, 1937: 197, called the name a synonym of Targionia Signoret, but Ferris, 1943a: 85, stated that it was definitely not Targionia.

Tecaspis Hall, 1946, Roy. Ent. Soc., London, Trans. $97:$ 499, 536.

TYPE-SPECIES: Chionaspis (Phenacaspis) visci var. umtali Hall, 1929, by original designation.

The author placed this genus in the Diaspidini closest to Rolaspis Hall. Balachowsky, 1954e: 369, assigned it to his Diaspidina, group II, chionaspiform, but considered it doubtfully distinct from Rolaspis.

Tectococcus Hempel, 1900, Rev. Mus. Paulista [Sao Paulo] 4: 406.

TYPE-SPECIES : Tectococcus ovatus Hempel, 1900, by original designation and monotypy.

Ferris, $1957 \mathrm{c}: 88$, redescribed the type-species and assigned the genus to the Eriococcidae. Hoy, 1963, New Zeal. Dept. Sci. and Indus. Res. Bul. 150: 14, confirmed this assignment.

Tectopulvinaria Hempel, 1899, in Cockerell, Canad. Ent. 31: 331, nomen nudum; 1900, Rev. Mus. Paulista [Sao Paulo] 4: 417, 482.

TYPE-SPECIES: Tectopulvinaria albata Hempel, 1900, by original designation and monotypy.

The author placed this genus in a key to the genera of the Lecaniinae. It is allied to Pulvinaria Targioni-Tozzetti. 
Tekaspis Lindinger, 1957, Beitr. z. Ent. $7: 552$.

An emendation of Tecaspis Hall.

Temnaspidiotus MacGillivray, 1921, The Coccidae, p. 387.

TYPE-SPECIES: Aspidiotus excisus Green, 1896, by original designation and monotypy.

The author placed this genus in the Aspidiotini. Lindinger, 1937: 197, assigned the name to synonymy with Aspidiotus Bouché. Ferris, 1938: 43, agreed with this view but, $1952 \mathrm{a}: 8$, reviewed the question and decided that Temnaspidiotus should be separated from Aspidiotus. Balachowsky, 1956: 132, accepted Temnaspidiotus as distinct in the Aspidiotina, Aspidiotini.

Tenuiaspis MacGillivray, 1921, The Coccidae, p. 308.

TYPE-SPECIES: Chionaspis minuta Green, 1896, by original designation and monotypy.

The author described this genus in the Diaspidini. Ferris, 1937a: 6, accepted it as a valid segregate from Chionaspis Signoret. Balachowsky, 1954e: 171-172, placed it in his Diaspidina, group II, chionaspiform.

Termitococcus Silvestri, 1901, Mus. di Zool. et Anat. Comp. Bol. [Torino Univ.] 16 (395) : 4.

TYPE-SPECIES : Termitococcus asper Silvestri, 1901, by subsequent designation of Fernald, 1903b : 122.

The author placed this genus originally in the Coccidae (str.) but, 1936: 32, 34, redescribed the genus and assigned it to the Margarodini.

Tessarabolus Vayssière, 1923, Ann. des Épiphyt. 9:427.

A lapsus for Tessarobelus Montrouzier.

Tessarobelus Montrouzier, 1864, in Perroud and Montrouzier, Soc. Linn. de Lyon, Ann. (n. s.) 11:246.

TYPE-SPECIES: Tessarobelus guerinii Montrouzier, 1864, by monotypy.

This genus presumably assigns to the Margarodidae. Vayssière, 1923a: 427, placed the name as a synonym of Monophlebus Burmeister.

Tetrura Lichtenstein, 1882, Wien. Ent. Ztg. 1: 124; 1882, Ent. Monthly Mag. 18: 275; 1882, Soc. Ent. de France Ann. (Bul. Ent.) (ser.6) 2:lxxv; 1882, Soc. Ent. Ital. Bul. $14: 330$.

TYPE-SPECIES: Tetrura rubi Lichtenstein, 1882 (non Coccus rubi Schrank, 1801), by monotypy.

The status of this genus and its type-species is confusing. The author published Tetrura, almost simultaneously in the serials cited. The name, apparently, had been used in 1844 in Aves. The only species originally included was misidentified as Coccus rubi Schrank, 1801. Cockerell, 1900b: 86, proposed that this species be called rubi Lichtenstein, 1882. Lindinger, 1937: 197, placed $T$. rubi Lichtenstein (non Schrank) as a synonym of Coccus comari Kunow, 1880, but accepted Tetrura as a valid genus. Borchsenius, 1949: 301, rejected this 
synonymy. Schmutterer, 1952: 400, considered this coccid under the name Phenacoccus comari (Kunow) with recognition of Lindinger's placement. An old preparation in the U.S. National Collection of Coccoidea, from Montpelier, by Richter, is probably authentic. It shows the adult female of the type-species to be a mealybug of the Phenacoccus series, and the body shape and such characters as can be seen check very well with the Schmutterer figures. The antennae are missing but two cicatrices are plainly visible. As of now, it seems best to consider that Schmutterer's 1952 description applies to Tetrura rubi Lichtenstein. This places the species in the aceris section (with multiple circuli) of Phenacoccus, and makes Tetrura Lichtenstein, preoccupied, a synonym of Phenacoccus Cockerell.

Thekes [Crawford MS] Maskell, 1892, New Zeal. Inst. Trans. and Proc. (1891) $24: 28$.

TYPE-SPEcIEs : Acanthococcus multispinus Maskell, 1879, by original designation.

Maskell, in comments following his description of "Eriococcus eucalypti," noted that the species had appeared in Crawford's collection as "Thekes eucalypti." He placed it in the section of Eriococcus Targioni-Tozzetti of which E. multispinus was the type. Cockerell, 1897p: 589, and 1899m: 276, listed Thekes as a subgeneric name in Eriococcus, citing eucalypti as type. Morrison and Morrison, 1922: 26, considered Thekes doubtfully distinct from Eriococcus, and Ferris, 1955a: 94, and $1957 \mathrm{c}: 85$, placed the name definitely as a synonym of Eriococcus. Hoy, 1963, New Zeal. Dept. Sci. and Indus. Res. Bul. 150: 62, confirmed this.

Thymaspis Sulc, 1934, Acta Soc. Sci. Nat. Morav., 9(3) (Signatura F 79) : 2, 18 .

TYPE-SPECIES : Thymaspis fusca Šulc, 1934, by monotypy.

Ferris, 1937d: 105, placed this name as a synonym of Rhizaspidiotus MacGillivray and fusca as a synonym of Aspidiotus artemisiae Hall. Balachowsky, 1951: 650, accepted this placement. Bodenheimer, 1952: 343, considered the genus aspidiotine in type but not identical with Rhizaspidiotus.

Thysanaspis Ferris, 1955, Microentomology $20: 30$.

TYPE-SPECIES : Thysanaspis acalyptus Ferris, 1955, by monotypy.

The author, uncertain as to the position of this genus within the Diaspididae. grouped it with Anotaspis Ferris and Radionaspis Ferris as exhibiting great reduction of the characters available for generic separation. Balachowsky, 1958b: 335, placed it in the Leucaspidina. Takagi, 1961a: 94-95, 101, commented on the uncertainty of its affinities but believed them to lie with the Diaspidini.

Thysanococcus Stickney, 1934, U.S. Dept. Agr. Tech. Bul. 404: 116.

TYPE-SPECIES: Thysanococcus chinensis Stickney, 1934, by original designation.

The author placed this genus in his Phoenicococcini, which he considered, tentatively, as a part of the diaspine assemblage. 
Thysanofiorinia Balachowsky, 1954, Inst. Pasteur [Paris] Mém. Sci., pp. 168, 312-314.

TYPE-SPECIEs : Fiorinia nephelii Maskell, 1898, by original designation and monotypy.

The author placed this genus in the Diaspidini, Diaspidina, close to Fiorinia Targioni-Tozzetti.

Tollaspidiotus MacGillivray, 1921, The Coccidae, p. 389.

TYPE-SPECIEs: Aspidiotus (? Chrysomphalus) mauritianus Newstead, 1917, by original designation.

The author placed this genus in the Aspidiotini. Lindinger, 1937: 197, considered the name a synonym of Furcaspis Lindinger and the type-species the same as Furcaspis oceanica Lindinger. McKenzie, 1939:54; Ferris, 1941e:45; and Mamet, $1949: 65$, accepted the genus as valid.

Tolypecoccus Hoy, 1962, New Zeal. Dept. Sci. and Indus. Res. Bul. $146: 188$.

TYPE-SPECLEs : Tolypecoccus latebrosus Ноу, 1962, by original designation and monotypy.

The author placed this genus in the Eriococcidae, not close to any particular genus.

Toumeyella Cockerell, 1895, Psyche (1894-1896) (sup.) 7:2.

TYPE-SPECIES: Lecanium mirabilis Cockerell, 1895, by original designation and monotypy.

The author presented this as a subgenus of Lecanium Burmeister. Steinweden, 1929:227, associated it with Neolecanium Parrott and Pseudophilippia Cockerell, saying that he believed the three constituted a single genus.

Tozzetia Signoret, 1870, Soc. Ent. de France Ann. (ser. 4) 10:282.

From the context of the statement in which this name occurs, it must be considered a lapsus for Targionia Signoret.

Trabutina Marchal, 1904, Paris Mus. d'Hist. Nat. Bul. 10: 449.

TYPE-SPECIES : Trabutina elastica Marchal, 1904, by original designation and monotypy.

Ferris, 1950b: 23, assigned this genus to a group of genera of the Pseudococcidae, including Naiacoccus Green, Amonostherium Morrison, and Nipaecoccus Š̉ulc.

Trabutinella Borchsenius, 1949, Akad. Nauk SSSR Dok. (n.s.) 63: 584.

TYPE-SPECIEs: Trabutinella tenax Borchsenius, 1948, by original designation and monotypy.

The author placed this genus in the Pseudococcidae close to Trabutina Marchal. 
Trachycoccus Borchsenius, 1950, Akad. Nauk SSSR Dok. 71: 781782.

TYPE-SPECIES : Asterolecanium tenax Bodenheimer, 1929, by original designation and monotypy.

The author placed this genus in the Asterolecaniidae near Asterolecanium Targioni-Tozzetti.

Trachycoccus Ferris, 1955, Atlas of the Scale Insects of North America $7: 215$.

TYPE-SPECIES: Trachycoccus hyperici Ferris, 1955, by original designation and monotypy.

The author referred this genus to the Dactylopiidae. The name is a homonym of Trachycoccus Borchsenius, 1950. Williams, 1961a: 93, proposed Hypericicoccus as a new name for the genus.

Trechocorys Curtis [Ruricola], 1843, Gard. Chron. No. 26 : 444.

TYPE-SPECIES : Coccus adonidum Linnaeus, 1767 , by original designation and monotypy.

The author proposed this name for the group of coccids commonly known as mealybugs. Some authors believe that, according to the Rules of Nomenclature, it should replace Pseudococcus Westwood as the valid name for this group. See under Pseudococcus for details.

Triaspidis MacGillivray, 1921, The Coccidae, p. 273.

TYPE-SPECIES: Mytilaspis bicornis Green and Lidgett, 1900, by original designation.

The author included 15 species in this lepidosaphine genus, many of which are not congeneric with the type-species. The genus has been accepted as restricted to the type-species. Balachowsky, 1954e: 23, placed it in his Lepidosaphedina.

Triaspis Balachowsky, 1954, Inst. Pasteur [Paris] Mém. Sci., p. 23. A lapsus for Triaspidis MacGillivray.

Trichococcns Kanda, 1941, Insect World 44:4(68).

A printer's error for Trichococcus Kanda.

Trichococcus Kanda, 1941, Insect World 44:4-8 (68-72)? (in Japanese).

TYPE-SPECIES : Xylococcus napiformis Kuwana, 1914, by original designation, and monotypy (apparently).

The author placed this genus close to Xylococcus Löw.

Trichococcus Borchsenius, 1948, Akad. Nauk SSSR Dok. (n.s.) 60: 503.

TYPE-SPECIES : Trichococcus filifer Borchsenius, 1948, by original designation and monotypy.

The author placed this genus in the Eriococcinae, Pseudococcidae, near Acanthococcus Signoret. Hoy, 1963, New Zeal. Dept. Sci. and Indus. Res. Bul. 
150: 15, placed the genus in the Eriococcidae on the basis of the published description. Trichococcus Borchsenius is a homonyn of Trichococcus Kanda.

Trichomytilus Leonardi, 1898, Riv. di Patol. Veg. (1897) 6: 45-46.

TYPE-SPECIES : Mytilaspis formosa Maskell, 1893, by monotypy.

Morrison and Morrison, 1922: 106, considered that this genus should be included in the Chionaspis Signoret series rather than the Lepidosaphes Shimer group. Ferris, 1941a: 12, accepted the genus as valid.

Tridisculus Ferris, 1950, Atlas of the Scale Insects of North America (ser. 5) [v. 5]: 13 .

A lapsus for Tridiscus Ferris.

Tridiscus Ferris, 1950, Atlas of the Scale Insects of North America (ser. 5) [v. 5]:21, 248.

TYPE-SPECIES: Trionymus distichlii Ferris, 1918, by original designation.

The author placed this genus in the Pseudococcidae, distinct from Trionymus Berg. McKenzie, 1960:692, and 1962:640, 686, accepted it as a valid genus.

Trigonaspis Ferris, 1941, Atlas of the Scale Insects of North America (ser. 3) [v. 3] : SIII-321.

TYPE-SPECIES : Trigonaspis inclusa Ferris, 1941, by original designation.

The author placed this genus in the Pseudoparlatoria Cockerell group of the Diaspidini, Diaspidinae and, 1942: SIV-423, substituted the name Vinculaspis because of prior use of Trigonaspis in Hymenoptera (1840), in Trilobita (1849) and in Coleoptera (1924). Lindinger, 1957: 552, transferred seven of the included species, but not the type-species, to Cryptaspidus Lindinger. This action has not been confirmed by other workers.

Trimerococcus Balachowsky, 1952, Soc. d'Hist. Nat. de l'Afrique du Nord, Bul. 43 (8-9) : 177.

TYPE-SPECIES : Trimerococcus icosianus Balachowsky, 1952, by original designation and monotypy.

The author placed this genus in the Phenacoccus group of the Pseudococcidae, related to Phenacoccus Cockerell and Puto Signoret.

Trionymus Berg, 1899, Mus. Nac. de Buenos Aires Comun. 1: 78.

TYPE-SPECIES : Westwoodia perrisii Signoret, 1875, by substitution of Trionymus for Westwoodia Signoret.

The author proposed this name as a substitute for Signorctia Kratz. 188. preoccupied, which had been proposed earlier as a substitute for Wextuoodia Signoret, 1875 , preoccupied. It is currentls accepted as the ralid name for this unit. See under Westwoodia for details. 
Triraphaspis Balachowsky, 1954, Inst. Pasteur [Paris] Mém. Sci., pp. 139-140.

TYPE-SPECIES: Lepidosaphes desmidioides Green, 1917, by original designanation and monotypy.

The author placed this genus as a deviating member of the Diaspidini, Lepidosaphedina, but showing the general characters of the subtribe. Mamet, $1957: 367$, and $1959: 126$, accepted the genus and described two new species in it.

Troggattiella Lindinger, 1957, Beitr. z. Ent. $7: 549$.

A lapsus for Froggattiella Leonardi.

Trullifiorinia Leonardi, 1906, Redia (1905) 3:17, 41.

TYPE-SPECIES : Fiorinia acaciae Maskell, 1892, by subsequent designation bs MacGillirray, 1921: 372 .

The author presented this as a subgenus of Fiorinia Targioni-Tozzetti. Ferris, $1936 a: 23,26$, accepted the genus as valid in the Diaspidini.

Truncaspidiotus MacGillivray, 1921, The Coccidae, p. 390.

TYPE-SPECIES : Lecanium capense Walker, 1852, by original designation and monotypy.

The author placed this genus in the Aspidiotini. Ferris, 1937c:52, 56, and 1938a : SII-230; and Lindinger, 1937: 197, and 1943b:220, placed the name as a synonym of Furcaspis Lindinger.

Tryonymus Dunham, 1954, [Bahia] Bol. Inst. Biol. 1: 68.

A lapsus for Trionymus Berg.

Tsimanaspis Mamet, 1959, Inst. Sci. de Madagascar, Mém. (1959) (Sér. E. Ent.) 11:477-478.

TYPE-SPECIES : Tsimanaspis euphorbiae Mamet, 1959, by original designation and monotypy.

The author referred this genus to the Aspidiotini, although he considered its affinities doubtful and noted a relationship to Comstockiella Cockerell.

Tsugaspidiotus Takahashi and Takagi, 1957, Kontyu 25: 103.

TYPE-SPECIES : Aspidiotus tsugae Marlatt, 1911, by original designation.

The authors placed this genus in the Aspidiotini, related to Dynaspidiotus Thiem and Gerneck.

Tsukushiaspis Kuwana, 1928, [Japan] Min. Agr. and Forestry Dept. Agr. Sci. Bul. 1:30.

TYPE-SPECIES: (Leucaspis bambusae Kuwana, 1902)=Chionaspis pseudoleucaspis Kuwana, 1923, by original designation.

The name has been generally accepted to be a synonym of Kuxanaspis MacGillivray. 
Tsurushiaspis Balachowsky, 1930, Soc. Ent. de France Bul. (1930) (No.10) : 179 .

A lapsus for Tsukushiaspis Kuwana.

Tulefiorinia Mamet, 1959, Inst. Sci. de Madagascar, Mém. (1959) (Sér. E. Ent.) 11:461-462.

TYPE-SPECIES : Tulefiorinia simplex Mamet, 1959, by original designation and monotypy.

The author placed this genus in the Diaspidini, closely related to Thysanofiorinia Balachowsky.

\section{Tychea Koch, 1857, Die Pflazenläuse Aphiden v. 1: 296.}

Aphidologists have accepted Tychea Koch as an aphid genus with Tychea graminis Koch as the type-species. Lindinger, 1943b:265, 1943c: 250, considered it a coccid genus and announced its precedence over Ripersia Signoret, which he placed as a synonym. He placed Tychea graminis Koch as a synonym of Coccus phalaridis Linnaeus, 1758. Lepesme, $1947: 262$, presented this concept of Tychea as a valid genus with Ripersia placed in synonymy. Other coccidologists have not accepted it.

From an examination of the Koch illustrations and descriptions, it is clear that Koch mixed a mealybug and an aphid in his generic characterization and in his illustrations and description of Tychea graminis Koch. T. amycli seems to be an aphid, without question. While the beak, the first item mentioned in the generic description, is that of an aphid, the remaining characteristics covered are coccid, as is the insect chiefly involved in the habitus discussion. As to the figures, that (365) of the fully-developed "stem mother" is a mealybug, and the figure (366a) of the larva seems to be also; the figure ( $366 \mathrm{~b})$ of the "perfect daughter" is that of an aphid.

Tylococcus Newstead, 1897, Ent. Monthly Mag. 33 : 165.

TYPE-SPECIES : Tylococcus madagascariensis Newstead, 1897, by monotypy.

A large number of species have been referred to this ant-associated pseudococcine genus. Of these, Mamet, 1953: 250, reported that only the four species described from Madagascar and one from the African Gold Coast were probably congeneric.

Udinia De Lotto, 1963, Roy. Ent. Soc., London, Proc. Ser. B : Taxonomy $32: 195$.

TYPE-SPECIES : Udinia scitula De Lotto, 1963, by original designation.

The author established this genus in the Coccidae (str.) and noted its close resemblance to Saissetia Déplanche.

Uhleria Cooke, 1881, Treatise on the Insects Injuries to Fruit and Fruit Trees of the State of California, p. 41.

TYPE-SPECIES : Eriococcus araucariae [Maskell, 1878], by monotypy.

The author presented "Uhleria araucariae, Comstock" as the name of a coccid found on Norfolk Island Pine at Santa Barbara, with no actual generic description or type designation. The sparse descriptive notes were inadequate, but if 
this can be considered to be Eriococcus araucariae Maskell, a common species on Norfolk Island Pine, Uhleria will fall into synonymy with Eriococcus TargioniTozzetti. If, at some future date, there is a splitting of the genus Eriococcus that involves a transfer of the species $E$. araucariae, Uhleria Cooke will be available.

Uhleria Comstock, 1883, Cornell Univ. Agr. Expt. Sta., Dept. Ent. Rpt. (1882-1883) 2:110.

TYPE-SPECIES : Fiorinia pellucida Targioni-Tozzetti, 1868, [Diaspis fioriniae Targioni-Tozzetti, 1867], by original designation.

The author proposed this name as a substitute for Fiorinia Targioni-Tozzetti, 1868, which he considered invalid for nomenclatorial reasons. Coccid workers have accepted the validity of Fiorinia and placed Uhleria as a synonym.

Ultracoelostoma Cockerell, 1902, Entomologist 35 : 114.

TYPE-SPECIES : Coelostoma assimile Maskell, 1890, by original designation and monotypy.

The author presented this as a subgenus of Coelostoma Maskell. Morrison and Morrison, 1922: 11-14, redescribed the type-species and placed the genus in the monophlebine, margarodine series, with affinities uncertain but closer to $X$ ylococcus Löw than to any other genus known at that time.

Umbaspis MacGillivray, 1921, The Coccidae, p. 306.

TYPE-SPECIES : Diaspis regularis Newstead, 1911, by original designation and monotypy.

The author placed this genus in the Diaspidini. Hall, 1946a : 515, 547, Lindinger, 1937: 197, and Ferris, 1937d : 105, placed the name as a synonym of Diaspis Costa. Balachowsky, 1954e : 198, accepted its validity in the Diaspidini, Diaspidina, very close to Diaspis Costa, noting that it included a series of African species.

Unachionaspis MacGillivray, 1921, The Coccidae, p. 307.

TYPE-SPECIES : (Chionaspis colemani Kuwana, 1902)=Fiorinia signata Maskell, 1897 , by original designation.

Coccid workers have accepted the validity of this genus. Balachowsky, 1954 e : 171 , placed it in his Diaspidina, group II, chionaspiform.

\section{Unaspidiotus MacGillivray, 1921, The Coccidae, p. 387.}

TYPE-SPECIES: Aspidiotus corticispini Lindinger, 1909, by original designation and monotypy.

Lindinger, 1937 : 197, said : "= Morganella Ckll." Ferris, 1937c : 52, and 1941e: 42 , listed the genus and its type-species without comment.

Unaspis MacGillivray, 1921, The Coccidae, p. 308.

TYPE-SPECIES: Chionaspis acuminata Green, 1896, by original designation and monotypy.

Lindinger, 1937: 197, synonymized this name with Chionaspis Signoret but other authors have accepted the genus as valid. Rao, 1949:59-65, reviewed and redescribed it. Balachowsky, 1954e : 170, 288-289, assigned it to his Diaspidina. 
Ungulaspis MacGillivray, 1921, The Coccidae, p. 274.

TYPE-SPECIES: Lepidosaphes ungulata Green, 1905, by original designation and monotypy.

The author placed this genus in the Lepidosaphini. Ferris, 1937a: 6, considered its generic status indeterminabe but Balachowsky, 1954e: 23, accepted the genus, and assigned it to his Lepidosaphedina.

Urococcus Lindinger, 1937, Ent. Jahrb. 46:192, 197.

A lapsus for Ourococcus Fuller.

Variaspis Lindinger, 1932, Konowia 11:186.

TYPE-SPECIEs : Protodiaspis lagunae Ferris, 1921, by original designation and monotypy.

Ferris, 1937a: 3, 6, placed this name as a synonym of Protodiaspis Cockerell.

Varicaspis MacGillivray, 1921, The Coccidae, p. 390.

TYPE-SPECIES : Aspidiotus fiorineides Newstead, 1920, by original designation and monotypy.

The author placed this genus in the Aspidiotini. Lindinger, 1937: 197, said, "=Aspidiotus Bouche." Ferris, 1937e: 52, listed the genus with its type-species without comment.

Velataspis Ferris, 1937, Atlas of the Scale Insects of North America (ser. 1) [v. 1]: SI-131.

TYPE-SPECIES : Scobinaspis dentata Hoke, 1921, by original designation.

The author placed this genus in the Diaspidini. Balachowsky, 1954e: 91, assigned it to the Lepidosaphedina and included among its species, serrifrons Leonardi, type-species of Scobinaspis MacGillivray, 1921. If this placement is confirmed, Velataspis will fall into synonymy with Scobinaspis.

Versiculaspis MacGillivray, 1921, The Coccidae, p. 312.

TYPE-SPECIES : Chionaspis (Dinaspis) diosmae Brain, 1920, by original designation and monotypy.

The author placed this genus in the Diaspidini. Ferris, $1938 \mathrm{~b}: 58$, considered it valid as to separation from Chionaspis Signoret. Hall, 1946a : 499, accepted it. Balachowsky, 1954e: 171, assigned it to his Diaspidina, group II, chionaspiform.

Villigera Karsch, 1877, Revision der Gallmücken, p. 16.

TYPE-SPECIES: Villigera frauenfeldi Karsch, 1877, by original designation and monotypy.

The trpe-species was first described in considerable detail and figured under the name of "eine Cecidomyia" by ron Frauenfeld, 1859: 247. From the Karsch discussion, it appears that the new genus and species were based wholly on the original Frauenfeld description and figure. A study of these shows that the insect represented is quite certainly the male of a species of Drosicha Walker. 
Vinculaspis Ferris, 1942, Atlas of the Scale Insects of North America (ser.4) [v.4]: SIV-423.

TYPE-SPECIES : Trigonaspis inclusa Ferris, 1941, by substitution of Vinculaspis for Trigonaspis Ferris.

The author presented this name as a substitute for Trigonaspis Ferris, preoccupied.

Vinsonia Signoret, 1872, Soc. Ent. de France Ann. (ser. 5) 1:423; 1872, (ser. 5) 2:33.

TYPE-SPECIES : (Vinsonia pulchella Signoret, 1892) $=$ Coccus stellifer Westwood, 1871, by monotypy.

The author described this genus as very close to Ceroplastes Gray. Lindinger, $1937: 198$, placed the name in synonymy with Ceroplastes. Other authors have accepted it as a distinct genus.

Visonia Ashmead, 1891, Amer. Ent. Soc. Trans. 18: 99.

A lapsus for Vinsonia Signoret.

Vitacoccus Reháček, 1954, Casopis Moravskeho Mus. Vědy přír. 39 : 141.

A lapsus for Vittacocous Borchsenius.

Vittacoccus Borchsenius, 1952, Akad. Nauk SSSR Zool. Inst. Trudy $12: 271$.

TYPE-SPECIES : Lecanopsis longicornis Green, 1916, by original designation and monotypy.

The author placed this genus in the Filippiinae, Coccidae (str.), close to Lecanopsis Targioni-Tozzetti and Exaeretopus Newstead.

Volvicoccus Goux, 1945, Marseille Mus. d'Hist. Nat. Bul. [n.v. ( $5 ?)](1-2): 30$.

TYPE-SPECIES: Volvicoccus volvifer Goux, 1945, by original designation and monotypy.

The author presented this as a subgenus of Trionymus Berg. Its zoological status remains unsettled pending study of related forms in the Pseudococcidae.

Voraspis Hall, 1946, Roy. Ent. Soc., London, Trans. 97 : 499, 539.

TYPE-SPECIES : Chionaspis carpenteri Laing, 1929, by original designation.

The author referred this genus to the Diaspidini close to Phenacaspis Cockerell. Balachowsky, $1954 \mathrm{e}: 356$, placed it in his Diaspidina, group II, chionaspiform. Borchsenius and Williams, 1963, Brit. Mus. (Nat. Hist.) Ent. Bul. 13: 370 , confirmed its identity and noted its closeness to Rolaspis Hall.

Walkerana Lindinger, 1937, Ent. Jahrb. 46, 198.

An emendation of Walkeriana Signoret. 
Walkeriana Signoret, 1876, Soc. Ent. de France Ann. (1876) (ser. 5) $5: 390$.

TYPE-SPECIES : Coccus floriger Walker, 1858, by monotypy.

Morrison, 1928: 141, redescribed this genus and placed it in the Monophlebini, group 2.

Warajicoccus Kuwana, 1922, [Japan] Dept. Agr. and Comm., Imp. Plant Quar. Sta. Bul. 1:7.

TYPE-SPECIEs: Monophlebus corpulentus Kuwana, 1902, by original designation.

This name is currently considered a synonym of Drosicha Walker.

Warburtonia Green, 1918, Ann. Appl. Biol. 4: 231, nomen nudum.

TYPE-SPECIES: Warburtonia frenchi [Green ?] 1918, by monotypy, nomen nudum.

The author presented the name "Warburtonia frenchi" in a list of coccid species affecting Eucalyptus without other information. No other reference to this name has been located.

Websteriella Leonardi, 1899, (separate) Riv. di Patol. Veg. 8: 6-7; 1900, 8: 208-209.

TYPE-SPECIES : Coccus zizyphi Lucas, 1853, by original designation.

The author presented this as a subgenus of Parlatoria Targioni-Tozzetti with type-species as stated above. MacGillivray, 1921: 247, mistakenly named blanchardii Targioni-Tozzetti as type-species, and Ferris, 1936a:23, repeated the error. This name is currently considered a synonym of Parlatoria.

Westwoodia Signoret, 1875, Soc. Ent. de France Ann. (ser. 5) 5: 337.

TYPE-SPECIES : Westwoodia perrisii Signoret, 1875, by monotypy.

This name was preoccupied by Westwoodia Brullé, 1846, and other earlier applications. Kraatz, 1888: 176, proposed the name Signoretia, as a substitute, but later, 1888a : 360, in the same volume, indicated that Signoretia Kraatz was preoccupied by Signoretia Stål, 1859. See discussion under Signoretia. Trionymus Berg is the currently accepted valid name for this unit.

Xanthophthalma Cockerell and Parrott, 1899, in Cockerell, Biol. Centr. Amer. 2 (pt. 2 ) : 33.

TYPE-SPECIES : Xanthophthalma concinnum Cockerell and Parrott, 1899, by original designation and monotypy.

Ferris, 1938a : SII-173, redescribed this genus and placed it in the Xanthophthalmini, Diaspidinae, which he erected to receive it.

Xanthopkthmalma Ferris, 1957, Microentomology 22:65.

A lapsus for Xanthophthalma Cockerell and Parrott. 
Xenococcus Silvestri, 1924, Indian Mus. Rec. 26: 311-312.

TYPE-SPECIES : Xenococcus annandalei Silvestri, 1924, by original designation and monotypy.

The author suggested similarity to Orthezinella Silvestri in the Ortheziinae. Balachowsky, 1957a: 163, suggested that the affinities of this peculiar genus lie with the Eriococcini rather than the Ortheziinae. Hoy, 1963, New Zeal. Dept. Sci. and Indus. Res. Bul. 150: 15, rejected its placement in the Eriococcidae.

Xenolecanium Takahashi, 1942, Formosa Govt. Agr. Res. Inst. Dept. Agr. Rpt. 81:26-27.

TYPE-SPECIES: Xenolecanium mangiferae Takahashi, 1942, by original designation and monotypy.

The author noted a relation to Alecanium Morrison, Coccidae (str.).

Xerococcus Ferris, 1921, Stanford Univ. Pubs., Univ. Ser., Biol. Sci. $1: 80$.

TYPE-SPECIES : Xerococcus fouquieriae Ferris, 1921, by original designation and monotypy.

The author noted the wide divergence of this genus from the usual eriococcine type, yet believed that it belonged to the Eriococcus Targioni-Tozzetti group (Dactylopiidae, sens. str.). Hoy, 1963, New Zeal. Dept. Sci. and Indus. Res. Bul. $150: 15$, accepted its assignment to the Eriococcidae.

Xerophilaspis Cockerell, 1897, U.S. Dept. Agr., Div. Ent., Tech. Ser. $6: 14$.

TYPE-SPECIES : Aspidiotus prosopidis Cockerell, 1895, by original designation and monotypy.

The author presented this as a subgenus of Aspidiotus Bouché. Ferris, 1921b: 94, placed the genus in the Diaspidini, rejecting the MacGillivray, 1921: 395, assignment to the Aspidiotini.

Xiphuraspis Borchsenius and Williams, 1963, Brit. Mus. (Nat. Hist.) Ent. Bul. $13:$ 370, 372, 375 .

TYPE-SPECIES : Chionaspis spiculata Green, 1919, by original designation and monotypy.

The authors placed this genus in the Diaspidini, allied to Kuwanaspis MacGillivray.

Xylococculus Morrison, 1927, Biol. Soc. Wash. Proc. 40: 101.

TYPE-SPECIES: Xylococcus betulae Pergande, 1898, by original designation and monotypy.

The author established this genus for the reception of the North American species that had previously been placed in Xylococcus Löw. See Ferris, 1919b: 108-113, for comments on the validity of the included species. 
206 MISC. PUBLICATION 1015 , U.S. DEPT. OF AGRICULTURE

Xylococcus Löw, 1883, Zool.-Bot. Gesell. Wien. Verhandl. (1882) 32 : 274.

TYPE-SPECIEs : Xylococcus filiferus Löw, 1883, by monotypy.

Morrison, 1928: 41-44, redescribed both genus and type-species, placing them in the Xylococcini, Xylococcinae, Margarodidae. He reassigned the American species, formerly included, to his new genus $X y$ lococculus.

$\bigcirc$ 
